\title{
المواجهة الجنائية لجرائم تلوث البيئة السمعى دراسة مقارنة
}

دكتور

عبدالقادر الحسينى إبراهيه محفوظ

أستاذ القانون الجنائى المشارك بأكاديمية القاهرة الجديلة

والمحامى بالنقض والدستورية العليا 
الثثرة الصناعية والتقدم التكنولجى الذى يعيشه العالم تواكبه موجة ضخمة من المخاطر والأضرار التى تلحق بحياة وصحة الأنسان وتلعب الأشخاص المعنوية دورا كبيرا فى ذللك لعظم الدور الذى تقوم به فى تنظيم مناحى الحياة المختلفة خاصة

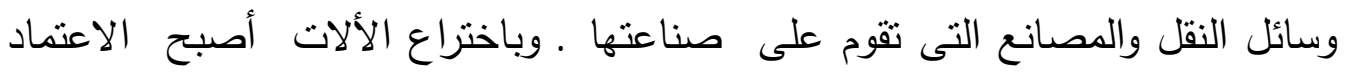
الكلى للإنسان عليها فى كافة مناحى الحياة المختلفة كل ذللك أدى إلى خلل فى البيئة

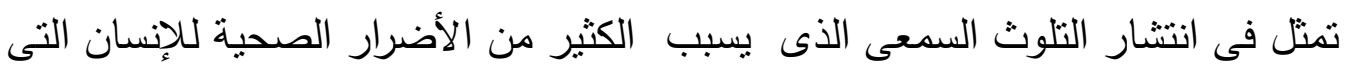
قد تتتهى به إلى الوفاة. فالتلوث البيئى لم يعد يقتصر على تلوث المياه والهواء والتربة وإنما ظهرت أنماط جديدة من التلوث الذى يهدد صحة وحياة الإنسان وهو التلوث

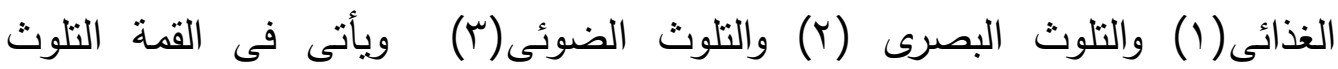
الضوضائى أو التلوث السمعى. فنظرا للنمو السريع في التحضر والتصنيع وتقدم العلم

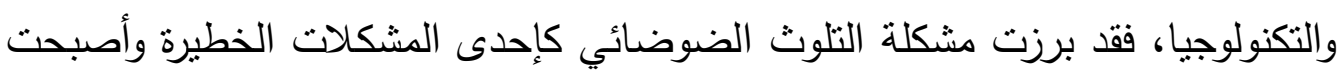
تمنل تحديًا خطيرًا لنوعية حياة الناس في معظم البلدان ـ وزادت قدرة الجنس البشري على لهى إحداث ضوضاء بشكل كبير مع ازدياد التقدم الصناعى. فالضجيج يحيط بنا، وهدير حركة مرور السيارات، وصخب الحشود، والتصنيع السربع، ومرور القطارات والطائرات .

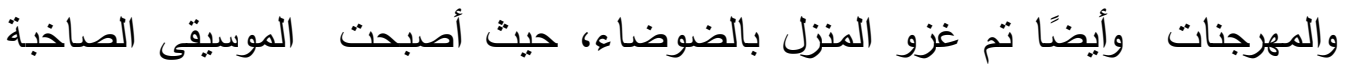
والكلاب أيضًا أسبابًا للضوضاء كل ذلك نسبب فى العديد من الأمراض والعديد من الوفيات .

(1) يقصد به أصابة المواد الغذائية كالخضروات والفاكهة والمحاصيل التى يعتمد عليها الأنسان بمواد

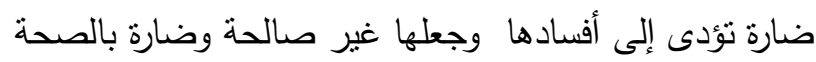

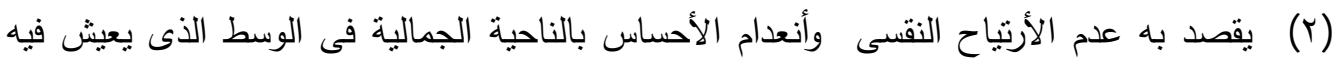

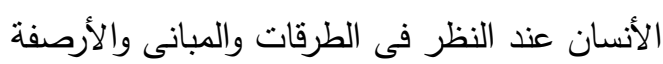
(r) يقصد به الأضاءة الليلية غير الطبيعية الضارة التى تخل بنظام البيئة التى تتمثل في الأثار

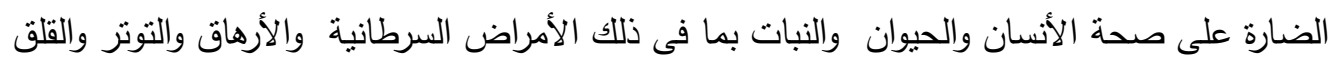


إثنكالية البحث: مع ازدياد النشاط الصناعى والتجارى وضخامة حجم الدور الذى تمارسه الأشخاص المعنوية فى هذا المجال وقصور دور القانون الجنائى فى مواجهة التلوث السمعى وماينتج عنه من أثنار ضارة ومميتة فبالنظر إلى البيانات الحالية، والتى تقدر أن الضوضاء البيئية تساهم في . . . ــ حالة جديدة من أمراض القلب سنويًا بالإضافة

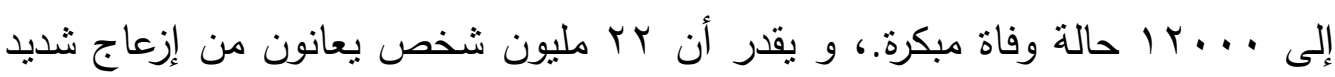

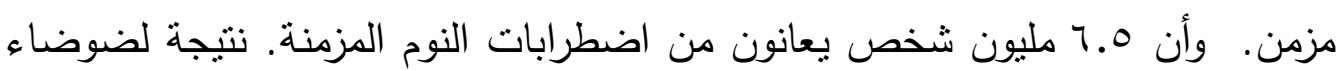

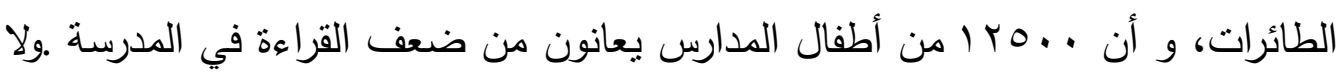
يدرك كثثر من الناس أن التلوث الضوضائي مشكلة مهمة تؤثر على صحة الإنسان، ،

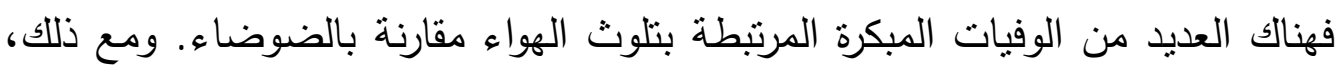
يبدو أن الضوضاء لها تأثنر أكبر على المؤشرات المتعلقة بنوعية الحياة والصحة العامة.

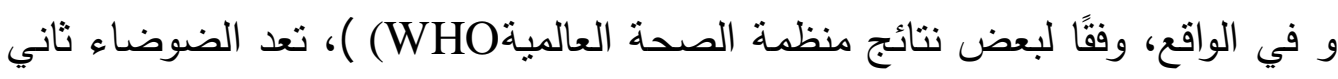
أكبر سبب بيئي للمشاكل الصحية على مستوى العالم، بعد تأثنر تلوث الهواء. فالتحضر

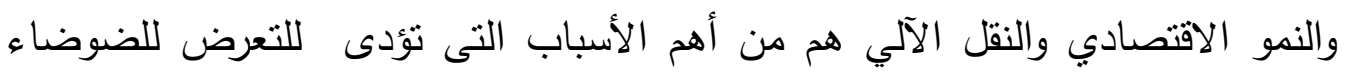
البيئية والآثار الصحية المميتة ـ ورغم ذلك فإن التلوث الضوضائي يحظى باهتمام أقل بكثير من مشاكل نقاء المياه وقضايا جودة الهواء لأنه لا يمكن رؤيته أو تذوقه أوشمه . كذلك فإن دور القانون الجنائى فى مواجهته يكاد يكون معدوما رغم ضخامة الأضرار الصحية التى يسببها.

أسئلة الدراسة: التعربف بالتلوث عموما. ماهو التلوث الضوضائى ما هي التأثيرات الصحية للتلوث السمعى؟ وما حجم مشكلة التلوث الضوضائي مقارنة بتلوث الهواء، مهي،

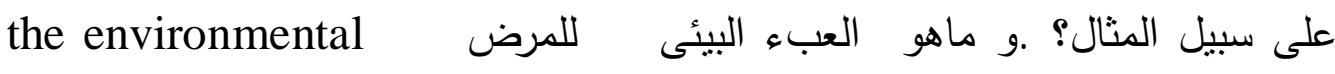
burden of disease مصادر التلوث الضوضائى التى يمكن أن يتسبب التعرض طويل المدى لها في في مجموعة منتوعة من الآثار الصحية السيئة بما في ذلك الازعاج واضطرابات النوم والآثار السلبية على القلب وأمراض الأوعية الدموية ونظام التمثيل الغذائي، فضلاً عن ضعف الإدراك والتزكيز لدى الكبار والأطفال . وماهو دور القانون الجنائى فى مواجهة 
التلوث السمعى بالمقارنة لدوره فى مواجهة أنواع التلوث الأخرى كالتلوت المائى والهوائى وتلوث التربة و كيف واجهت النشريعات العقابية جرائم التلوث الضوضائى. وماهو موقف الثريعة الإسلامية من ذلك وماهى الجزاءات التى قررتها القوانين للتلوث الضوضائى .

لذا نعالج هذا الموضوع من خلال تعربف البيئة محل التلوث السمعى (المبحث الأول)

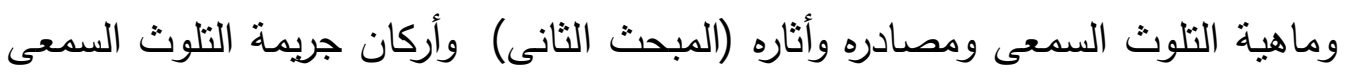

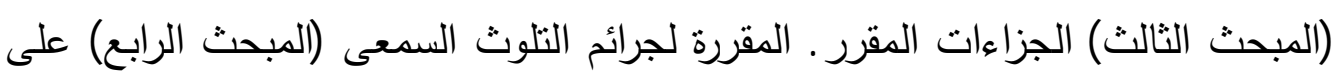

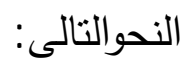

\section{مطلب تمهيدى}

\section{ماهية البيئة محل السلوك الإجرامى للتلوث السمى}

فى ظل العصر الحديث والتقدم التكنولجى وانتشار الألات وهيمنة الثورة الصناعية الكبرى على كافة مناحى الحياة كل ذللك كان السبب القوي الذي جعل كثيرًا من الدول تشعر بمدى الخطر الذي يهدد البيئة كقيمة يهتم القانون بحمايتها في شقها الطبيعي، كالماء، والهواء، والتربة، أو شقها الصناعي الذي أوجده الإنسان كالمنشآت لئات لئه والمدن والمصانع . ومفهوم البيئة يختلف باختلاف مهنة الثخص الذي ينظر إليها، فأستاذ

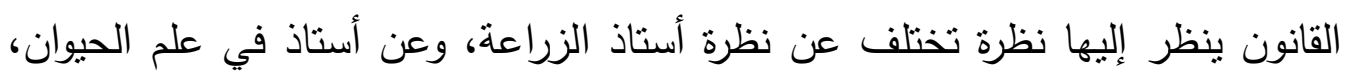
ومن هنا يختلف الرأي باختلاف عناصر البيئة المقصودة تبعا لوجهة نظر الثخص الذي لئي ينظر إليها، لكن ما يعنينا هو المفهوم القانوني للبيئة، فالمؤتمر الدولي للتربية البيئية الذي عقد في مدينة تبليس بجمهورية جورجيا بالاتحاد السوفيتي سابقا عام 19VV عرفها بأنها: الإطار الخارجي الذي يعيش فيه الإنسان ويحصل منه على مقومات حياته من

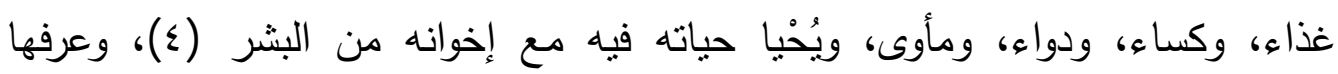

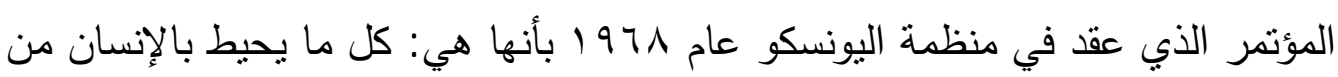

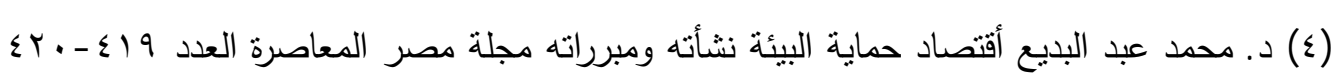
عام 199 
أثياء سواء أكانت مباشرة أو غير مباشرة، ويشمل ذلك جميع النشاطات والمؤثرات التي تؤثر على الإنسان مثل: الطبيعة، والظروف العائلية، والمدرسية، والاجتماعية، التي يدركها من خلال وسائل الاتصال المختلفة المتوافرة لديه بما في ذلك تراث الماضي (0)، فالبيئة هى الإطار الذى يمارس فيه الإنسان حياته وكافة أنشطته فهى الإطار أو الوسط الذى يحيط بالإنسان ويشتمل على كافة الجوانب المادية وغير المادية البشرية وغير البشرية فكل ماهو خارج عن كيان الإنسان يدخل فى نطاق البيئة كالموجودات

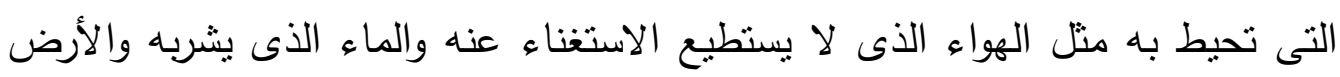
التى يعيش عليها ويزرعها وكل مايحيط به من كائنات حية أو جماد بعتبر من عناصر

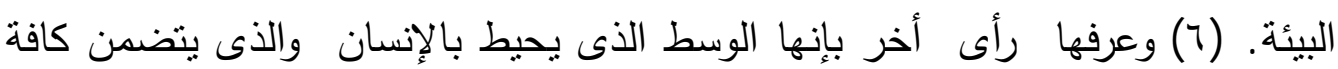
الجوانب المادية وغير المادية البشرية وغير البشرية. فهى الوسط الذى يشكل كل ماهو

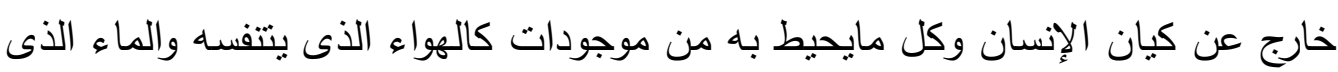

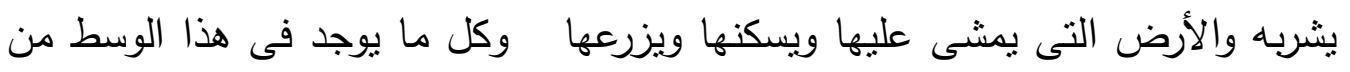

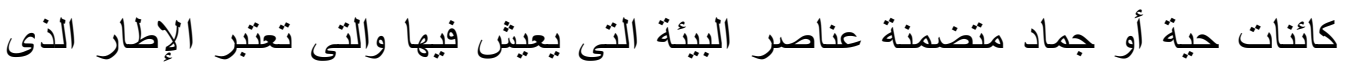

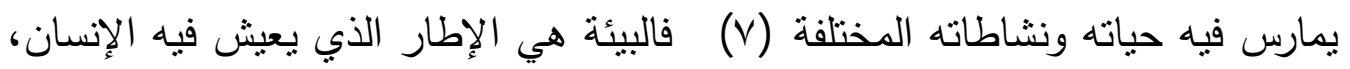
ويحصل منه على مقومات حياته: من غذاء، وكساء، ودواء، ومأوى، ويمارس فيه الإسه

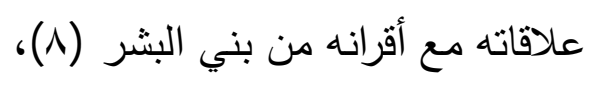

وعرفها المشرع الكويتي بأنها: المحيط الحيوي والفيزيائي الذي يشمل الكائنات

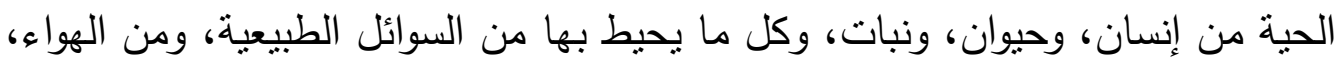

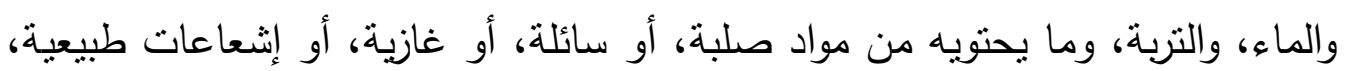

(0) د. أشرف هلال . جرائم البيئة بين النظرية والنطبيق دار الفكر العربى بالقاهرة الطبعة الأولى iv מ T...O

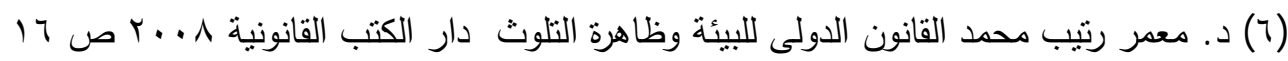

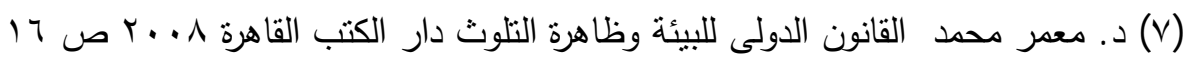

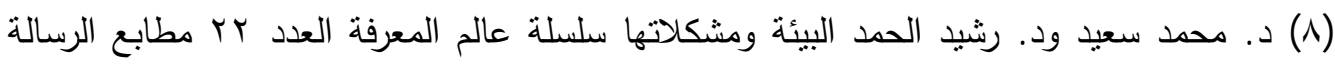

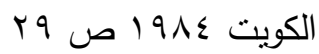


والمنشآت الثابتة والمتحركة التي يقيمها الإنسان . (9) ثم عرف حماية البيئة بأنها هي: مجموعة السياسات والتدابير التي تهدف إلى حماية الموارد الطبيعية، والنظم البيئية، والإجراءات التي تكفل منع التلوث، أو التخفيف من حدته أو مكافحته، والمحافظة على تلى البيئة، ومواردها الطبيعية، والتتوع الحيوي، وإعادة تأهيل المناطق التي تدهورت بسبب

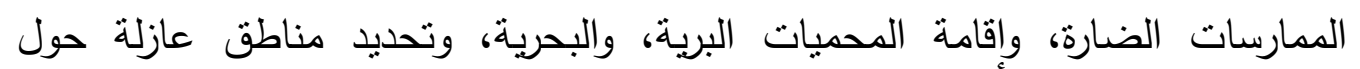

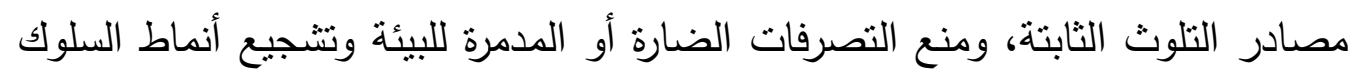
الإيجابي. (10) وفي فرنسا عرفت الفقرة الأولى من المادة • الم من قانون البيئة

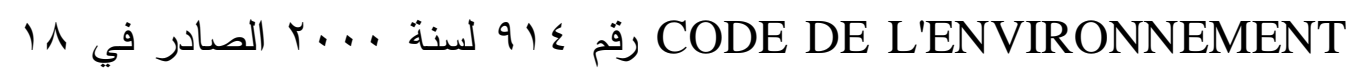
سبتمبر . . . البيئة بأنها: الفضاء، والمصادر الطبيعية، والمواقع السياحية، ونوعية الهواء، والوسط الحيواني، والنباتي، والتتوع البيولوجيي، ويعد كل هذا جزء من الملكية

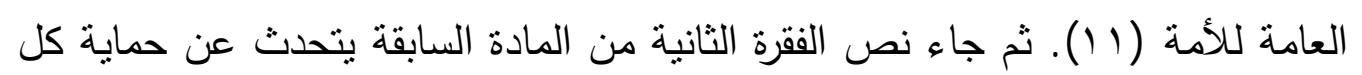
هذه العناصر المذكورة في الفقرة الأولى فجاء نصها : "أن حماية وتعزيز وترميم، وإعادة تأهيل، وإدارة هذه المصادر هو من المصلحة العامة، والمساهمة في أهداف التتمية

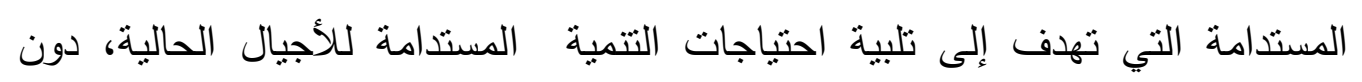

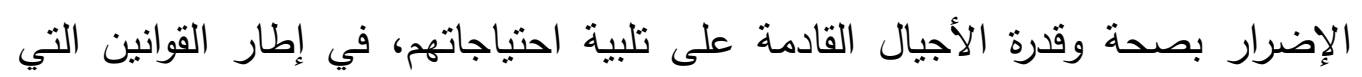
تحدد نطاقها) . (r) (1) (1)

(9) الفقرة السابعة من المادة الأولى من قانون حماية البيئة رقم 99 لسنة 10 ـ ب الخاص بتعديل القانون

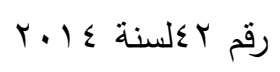
( • (1) الفقرة الحادية عشر من المادة الأولى من قانون حماية البيئة الكويتى (1) art. L. 110-1. - I. Les espaces, ressources et milieux naturels, les sites et paysages, la qualité de l'air, les espèces animales et végétales, la diversité et les équilibres biologiques auxquels ils participent font partie du patrimoine commun de :la nation

(I Y) II. Leur protection, leur mise en valeur, leur restauration, leur remise en état et leur gestion sont d'intérêt général et concourent à l'objectif de développement durable qui vise à satisfaire les besoins de développement et la santé des générations présentes sans compromettre la capacité des générations 
ويلاحظ أن قانون البيئة الفرنسي ربط مباشرة بين الحماية والمحافظة على عناصر البيئة الواردة في التعريف في الفقرة الأولى، وبين تحقيق التتمية المستدامة التي عرفها في الفقرة الثانية من ذات المادة، وهذا أمر لا غنى عنه، وفي موسوعة العلوم البيئية، فإن البيئة هي" مجموع الظروف الخارجية والتأثيرات التي تؤثز على حياة وتطور الكائن الحي."(13) - (13)

وعرفها رأي آخر بأنها: الوسط الطبيعي الذي يعيش فيه الإنسان وغيره من الكائنات، وهي تتكون من مجموع العوامل والعناصر التي تساعد تلك الكائنات على البقاء ودوام الحياة، أو هي مجموع الظروف، والعوامل، والعناصر الطبيعية، والحيوية، والاجتماعية، والثقافية المتفاعلة في توازن يهيء وسطا لحياة الإنسان. (ع () وعرفها

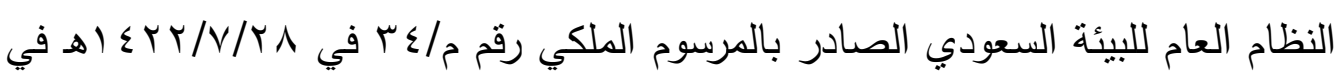
المادة الأولى في الفقرة السابعة منها بأنها هي: " كل ما يحيط بالإنسان من ماء، وهواء،

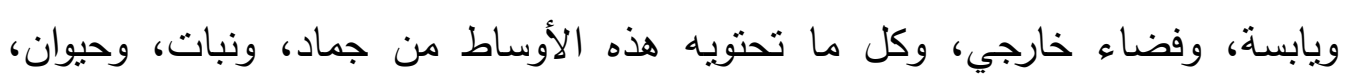
وأثنكال مختلفة، من طاقة، ونظم، وعمليات طبيعية، وأنشطة بشرية".

في حين أن المشرع المصري عرفها بأنها: المحيط الحيوي الذي يشمل الكائنات الحية، وما يحتويه من مواد، وما يحيط بها من هواء، وماء، وتربة، وما يقيمه الإنسان

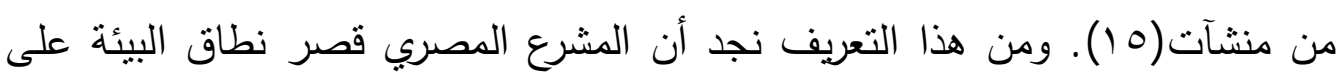
الوسط الطبيعي، والوسط الصناعي ولكنه عندما تحدث عن حمايتها نجد أنه قصر

futures à répondre aux leurs. Elles s'inspirent, dans le cadre des lois qui en définissent la portée,

(1)The Encyclopedia of Environmental Sciences defines Environment as "the aggregate

all external conditions and influences affecting life and development of an organism"

(ع () د. أحمد عبدالكريم سلامة ، مبادئ قانون حماية البيئة دراسة تأصيلية في الأنظمة الوطنية

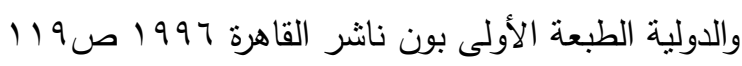

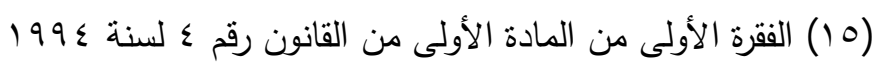


الحماية على الوسط الطبيعي فقط، فذكر المحافظة على مكونات البيئة والارتقاء بها، ومنع تدهورها أو تلوثها، أو الإقلال من حدة التلوث، ونتثمل هذه المكونات الهواء، والبحار، والمياه الداخلية، متضمنة نهر النيل، والبحيرات، والمياه الجوفية، والمحميات الطبيعية، والموارد الطبيعية الأخرى،(7 (1) وهذا يعكس مدى التناقض الذي وقع فيه المشرع المصري عندما عرف البيئة في الفقرة الأولى ثم تحدث عن حمايتها في الفقرة

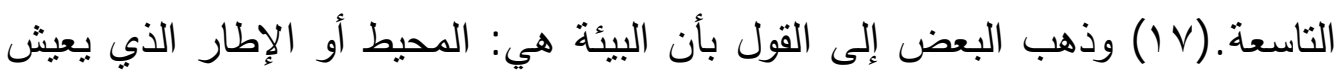

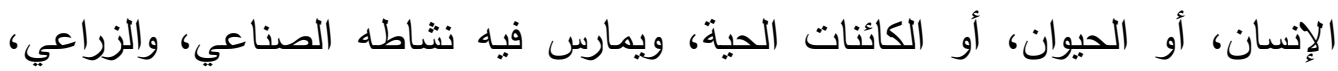
والاقتصادي، والاجتماعي، وتتأثز لظروفها أحواله الصحية، والنفسية، وتتكون من الهواء الذي يتتفسه فيصح به البدن إذا كان نقيا ويمرض به إذا كان فاسدا، والماء الذي يشربه

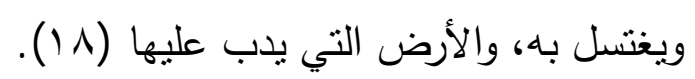

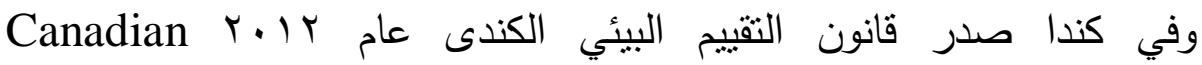

Environmental Assessment Act تعني مكونات الأرض وما يتضمنها من: - (أ) الأرض، والمياه، والهواء، بما في ذلك جميع طبقات الغلاف الجوي. (ب) جميع المواد العضوية، وغير العضوية، والكائنات

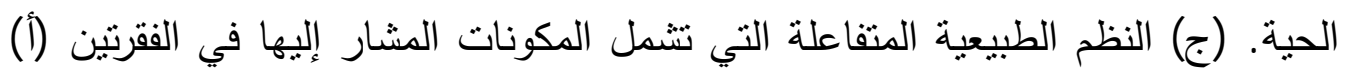
و (ب (من تعريف البيئة (19) وتحدثت الفقرة التالية عن معنى: التقييم البيئي (évaluation) environnementale

(7 (1) الفقرة التاسعة من المادة الأولى من القانون رقم علسنة ؟ 199

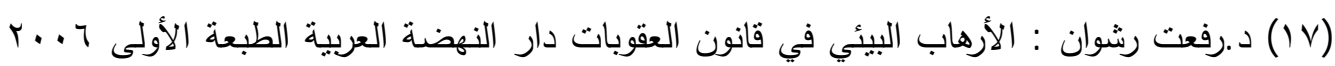
ص اب وامابعدها (1) د أحمد مدحت أسلام . التلوث مشكلة العصر سلسلة عالم المعرفة العدد 10 10 مطابع السياسة

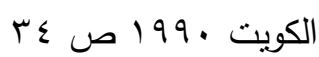
(19) environment means the components of the Earth, and includes

- (a) land, water and air, including all layers of the atmosphere;

- (b) all organic and inorganic matter and living organisms; and

- (c) the interacting natural systems that include components referred to in paragraphs (a) and (b) . (environnement) 
المعين الذي يتم وفقا لهذا القانون . (·r) وفي ولاية فيكتوريا الأمريكية صدر قانون

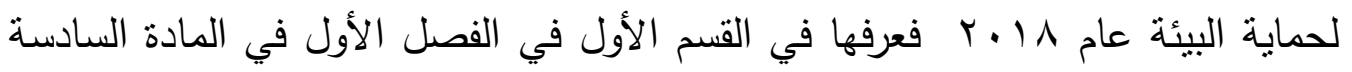
تحت عنوان definiations في الفقرة التاسعة بأنها تعني (أ) العوامل المادية المحيطة بالبشر بما في ذلك الأرض، المياه، الجو، المناخ، الأصوات، الروائح والأذواق (ب) بانيان

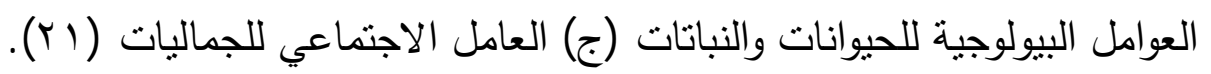
وفي باكستان صدر قانون حماية البيئة رقم 9 بو لسنة و9 احيث ذكرت المادة الثانية منه بأن البيئة: تعني (أ) الهواء، والماء، والأرض (ب) جميع طبقات البئه رفات الغلاف الجوي(ج) جميع المواد العضوية، وغير العضوية والكائنات الحية (د)النظام الإيكولوجي ولياءي والعلاقات الإيكولوجية (ه) المباني، والهياكل، والطرق، والمرافق، والأعمال (و ) جميع الظروف الاجتماعية، والاقتصادية، التي تؤثز على الحياة المجتمعية (ز) العلاقات المتداخلة بين أي من العوامل الواردة في البنود الفرعية من (أ) إلى (و ) (Y ( ) . وفي ولاية كوينزلاند الأسترالية صدر قانون حماية البيئة عام ؟9 9 1 فعرف البيئة في القسم الأول في المادة الثامنة بأنها نشمل: -

(20) environmental assessment means an assessment of the environmental effects of a designated project that is conducted in accordance with this Act

(21) environment means - (a) the physical factors of the surroundings of human beings including the land, waters, atmosphere, climate, sound, odours and tastes; and (b) the biological factors of animals and plants; and (c) the social factor of aesthetics;

(22) environment" means:-

a) air, water and land؛

b) all layers of the atmosphere!

c) all organic and inorganic matter and living organisms

d) the ecosystem and ecological relationships؛

e) buildings, structures, roads, facilities and works؛

f) all social and economic conditions affecting community life; and

g) the inter-relationships between any of the factors in sub-clauses (a) to ( $f$ ؛ 
(أ) النظم الإيكولوجية والأجزاء المكونة لها بما في ذلك الناس والمجتمعات. (ب) جميع الموارد الطبيعية والمادية (ج) صفات وخصائص المواقع والأماكن والمناطق مهما كانت كبيرة أو صغيرة، والتي تسهم في التتوع البيولوجي والسلامة الحقيقية المنسوبة إلى القيمة العلمية، أو الفائدة والراحة والانسجام والحس المجتمعي . (د) الظروف الاجتماعية، والاقتصادية، والجمالية، والتقافية، التي نؤثز أو تتأثز بالأمور المذكورة في الفقرات من (أ) إلى (ج) (rr) وصدر في الأردن قانون حماية البيئة رقم 7 لسنة ا •.r والذي عرف البيئة في المادة الثانية بأنها:" الوسط الذي يشمل الكائنات الحية وغير الحية، وما يحتوى عليه من مواد، وما يحيط به من هواء،

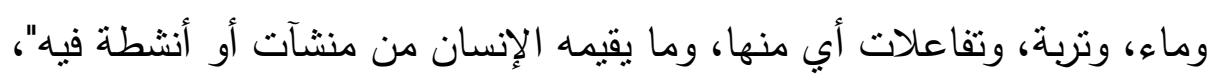
وذكرت ذات المادة عناصر البيئة بأنها هي: العناصر الحية وغير الحية في البيئة، كالماء، والهواء، والتربة، والأنواع، والأصول الوراثية، وهناك رأي يضع في العي اعتباره

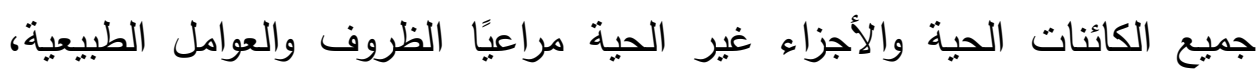
والفيزيائية، والحيوية التي تسود المحيط، أو السطح، وتجعله صالحا لحياة الكائنات

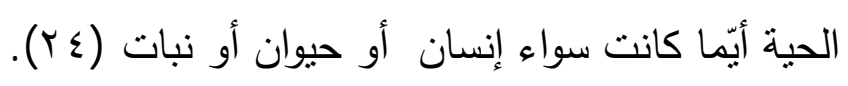

ويلاحظ أن للتشريعات البيئية للاتحاد الأوروبي تأثثرات كبيرة على الدول الأعضاء فيها، حيث تتناول التشريعات البيئية للاتحاد الأوروبي قضايا منل المطر الحمضي noise rain

(23) Environment includes- (a) ecosystems and their constituent parts, including people and communities; and (b) all natural and physical resources; and (c) the qualities and characteristics of locations, places and areas, however large or small, that contribute to their biological diversity and integrity, intrinsic or attributed scientific value or interest, amenity, harmony and sense of community; and (d) the social, economic, aesthetic and cultural conditions that affect, or are affected by, things mentioned in paragraphs (a) to (c) . ( ( ) د خالد خليل الطاهر قانون حماية البيئة في الأردن دراسة مقارنة الطبعة الأولى بدون ناشر 
sustainable energy وتلوث النفايات والمياه، والطاقة المستدامة pollution و يقدر معهد السياسة البيئية الأوروبية أن مجموعة قوانين البيئة في الاتحاد الأوروبي تزيد عن . م من التوجيهات واللوائح والقرارات، ومن منطلق أهمية البيئة لتحقيق التتمية المستدامة أنشئت هيئات، ومنظمات، للمحافظة عليها، ومنها مرفق

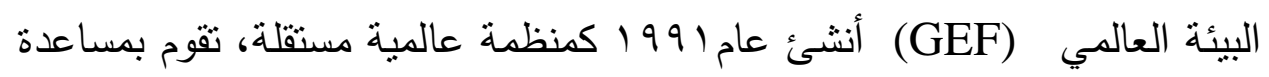
الدول النامية في تتفيذ مشروعات حماية البيئة العالمية، وتشجيع التتمية المستدامة في المجتمعات المحلية، .

ويوجد أيضًا الاتحاد العالمي لصيانة الطبيعة، وهو عبارة عن تجمع عالمي للمنظمات الحكومية وغير الحكومية النشطة في مجال حماية البيئة، وتعمل بصفة مشنركة على حماية وصيانة الطبيعة، وذلك من خلال الاستغلال الأمنل للموارد الطبيعية

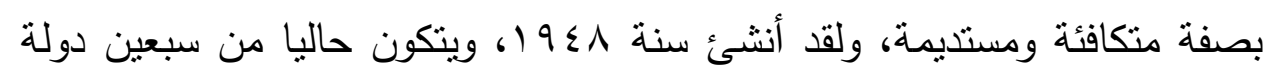
ومئة وكالة حكومية، ومن سبعمائة منظمة غير حكومية، ويعمل حاليا على مواجهة

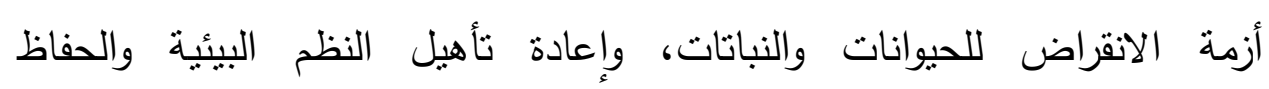

$$
\text { (ro). عليها (ro) }
$$

من كل التعربفات السابقة يتبين لنا أن عناصر البيئة محل جريمة التلوث السمعى تشمل الوسط الذي يعيش فيه الإنسان، سواء أكان وسطًا طبيعيًا كالماء، والهواء،

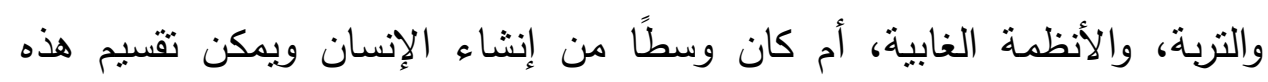

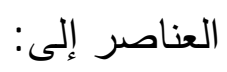

أولا - العناصر الطبيعية وهي العناصر التي لا دخل للإنسان في وجودها، وإنما هي سابقة حتى على وجود الإنسان نفسه، وتتمنت هذه العناصر في: -

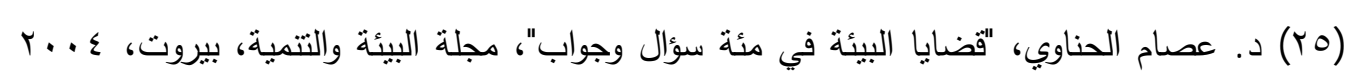
ט 1 r. 
1 - الهواء: ويعد الهواء أثنن عناصر البيئة، وسر الحياة، ولا يمكن الاستغناء عنه إطلاقًا، ويمثل الغلاف الجوي المحيط بالأرض والذى ينتقل من خلاله الصوت، وكل تغير يطرأ على مكوناته يؤدي إلى نتائج سلبية تؤثز على حياة الكائنات الحية، ومن السهولة بمكان نشر أي فيروس، أو غاز في الهواء، مما يشكل أثند صور بورئ الضرر البيئي .

r - الماء: هو مركب كيميائي ينتج من تفاعل غاز الأكسجين مع غاز الهيدروجين،

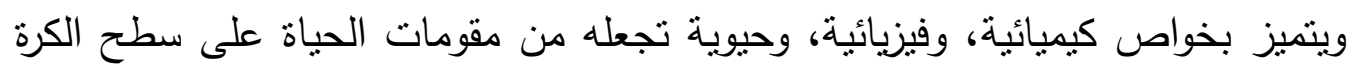

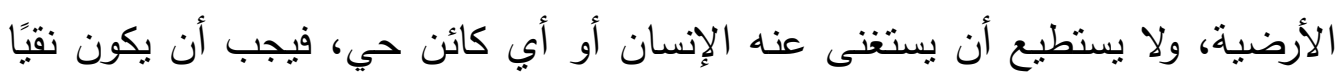

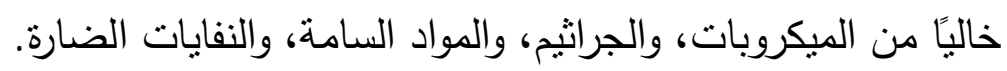
r - التربة: هي الطبقة التي تغطي صخور القشرة الأرضية، وهي مزبج من المواد

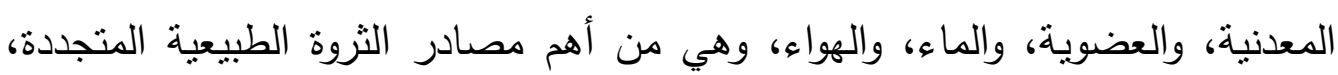
ومقومات الكائنات الحية.

ع - التنوع الحيوي: مصطلح يطلق لوصف تعدد أنواع الكائنات الحية الموجودة في النظام الأيكولوجي، ويقاس التتوع الحيوي في منطقة معينة أو في نظام أيكولوجي محدد

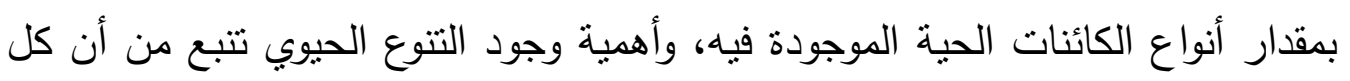
نوع من الكائنات الحية يقوم بوظيفة محددة في النظام الأيكولوجي، فإذا اختفى أي نوع

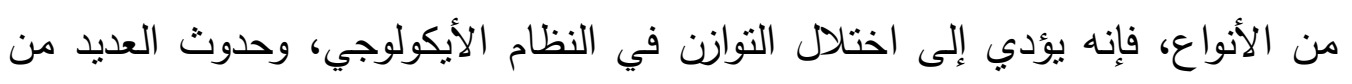
الإضرار بالبيئة، ومن أكثر العوامل التي تؤدى إلى نقص التنوع الحيوي الصيد الجائر

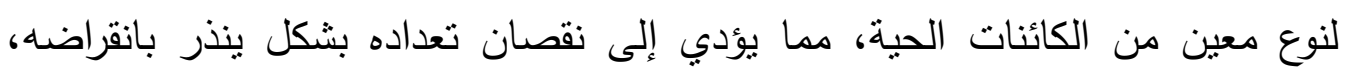

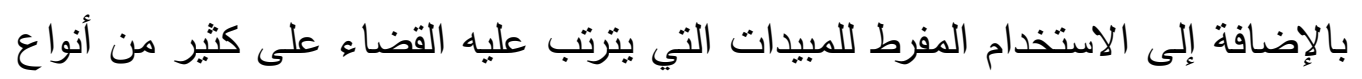
النباتات والحيوانات مع الكائنات المستهدفة أصلا بالمبيدات. ثانياً: - العناصر الاصطناعية: تقوم البيئة الاصطناعية أساسًا على ما أدخله الإنسان

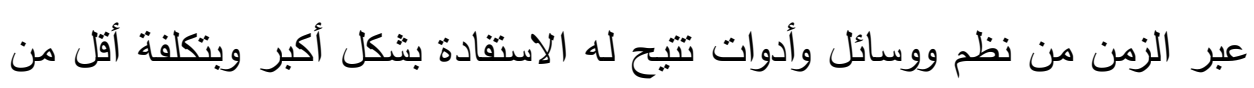
مقومات العناصر الطبيعية للبيئة، وذلك من أجل إثباع حاجياته ومنطلباته 
الأساسية، وحتى الكمالية منها حيث تتشكل العناصر الاصطناعية من البنية الأساسية المادية التي يشيدها الإنسان، ومن النظم الاجتماعية والمؤسسات التي أقامها، ومن ثم يمكن النظر إلى البيئة الاصطناعية من خلال الطريقة التي نظمت الإسئه بها المجتمعات حياتها، والتي غيرت البيئة الطبيعية لخدمة الحاجات البشرية، حيث تشمل البيئة الاصطناعية استعمال الأراضي للزراعة، وإنشاء المناطق السكنية وللتنقيب فيها عن الثروات الطبيعية وإنشاء المناطق الصناعية، والتجارية والخدماتية.....الخ، إذن فالبيئة الاصطناعية أو البيئة المشيدة ما هي إلا البيئة الطبيعية نفسها، ولكن بتدخل الإنسان وتطويع بعض مصادرها لخدمته. وعليه

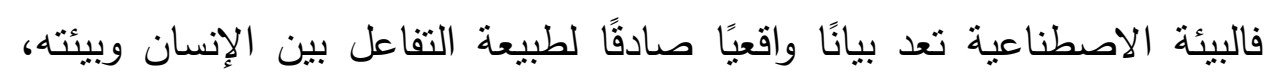
ومن هنا يأتى التلوث السمعى الذى يسبب كثير من الأضرار التى سوف نوردها

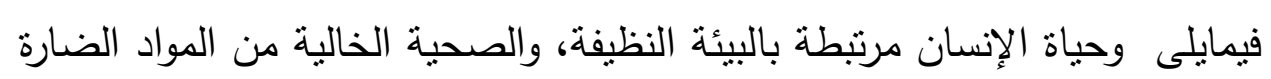

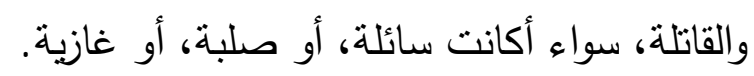




\section{المبحث الثانى}

\section{التلوث السمعى للبيئة ومصادرهوأثاره}

لقد كان القلق من الضوضاء، أو التلوث السمعىهحل نقاشًا مستمرًا في فرنسا لعدة

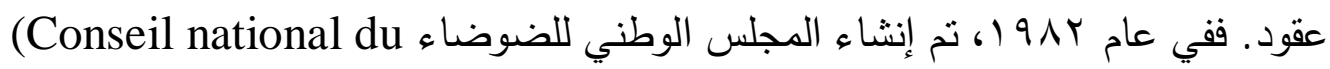
bruit)، وهو هيئة استشارية مهنتها اقتراح وإعلام وزيادة الوعي العام لدى الجمهور بشأن التلوث الضوضائي وعواقبه وأثنارة السيئة على صحة الإنسان والحيوان . و بعد ولهد عشر سنوات، من ذلك التاريخ صدر فى فرنسا أول تشريع للحد من الضوضاء وهو وهو

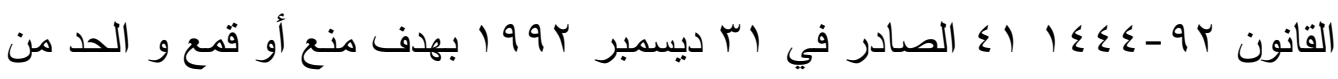
انبعاث أو انتشار الضوضاء التي تنكل خطرًا على الصحة العامة وتسبب إزعاجًا

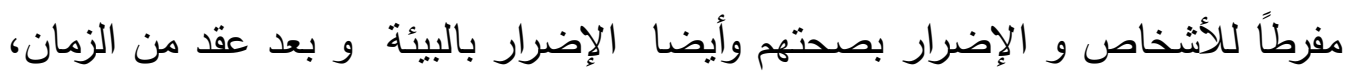

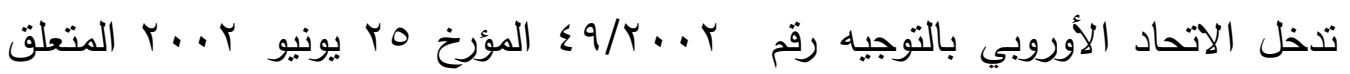
بتقييم وإدارة الضوضاء البيئية التي فرضت التزامات بشأن هذه المسألة على الدول الأعضاء. في قانون البيئة ونتكلم فى هذا المبحث تعريف التلوث السمعى (المطلب الأول) نم نتناول مصادر التلوث السمعى (المطلب الثانى) ثم نتناول الأثار الضارة للتلوث السمعى (المطلب الثالث) على النحوالتالى:

\section{المطلب الأول}

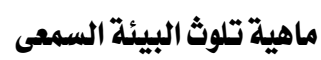

الحديث عن التلوث السمعى يجب الإشارة إلى التلوث بصفة عامة لبيان ما إذا كان

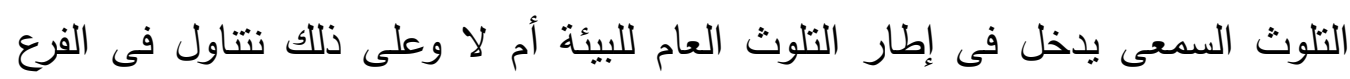

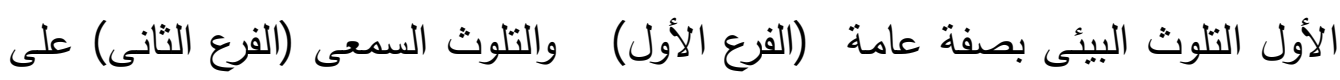

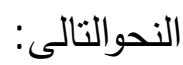




\section{الفرعالأول}

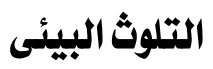

التلوث بصفة عامة يحدث بسبب تدخل الإنسان والعبث بمكونات الطبيعة

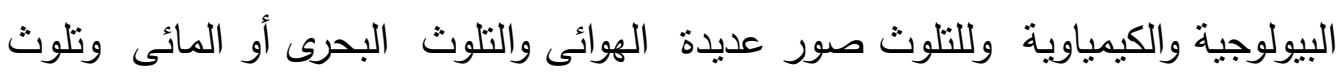
التربة والتلوث الغذائى والتلوث الضوئى و ويأتى فى المقدمة التلوث السمعى أو

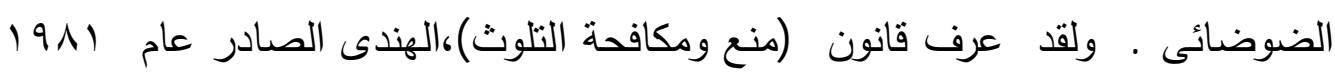
الضوضاء ضمن تعريف "ملوثات الهواء ." فى القسم الثانى وعرف تلوث الهواء

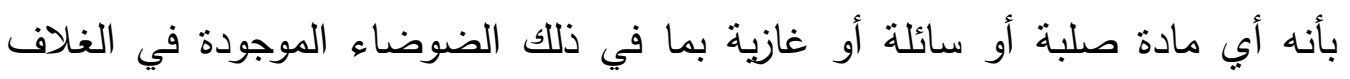

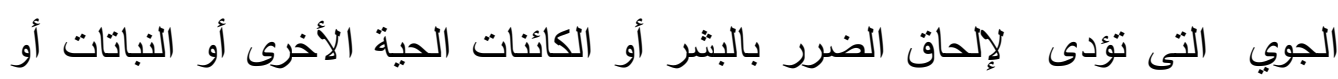
الممتلكات أو البيئة. وفي الفقرة التاسعة من المادة الأولى من النظام العام للبيئة

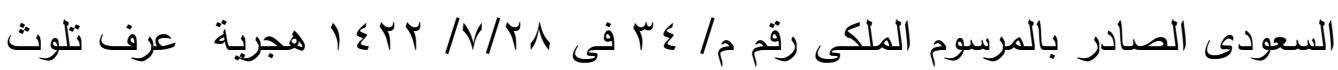
البيئة بأنه: " وجود مادة أو أكثر من المواد أو العوامل بكميات، أو صفات، أو لمدة زمنية تؤدي بطريق مباشر، أو غير مباشر ، إلى الإضرار بالصحة العامة، أو بالأحياء،

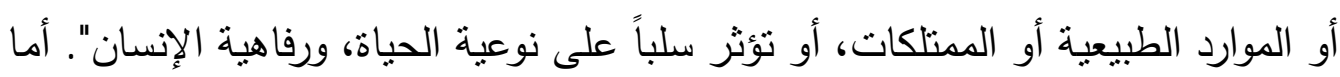
تدهور البيئة فعرفها النظام السعودي في الفقرة العاشرة بأنها: "التأثير السلبي على البيئة بما يغير من طبيعتها، أو خصائصها العامة، أو يؤدي إلى اختلال التوازن الطبيعي بين

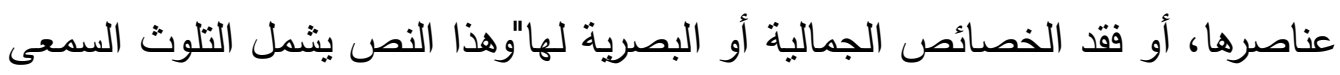
والتلوت البصرى والتلوث الضوئى .

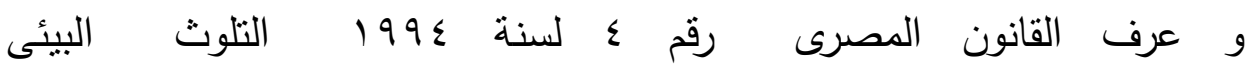
(Environmental Pollution بطريق مباشر أو غير مباشر إلى الإضرار بالكائنات الحية أو المنشأت أو يؤثنر على بإنه

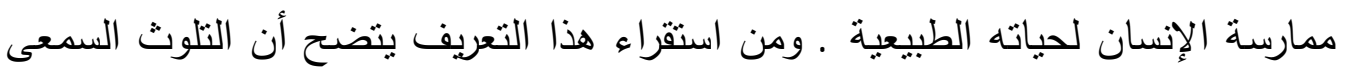
يندرج ضمنا فى إطار هذا التعريف باعتبار أنه يؤثز ويعيق الإنسان فى ممارسة

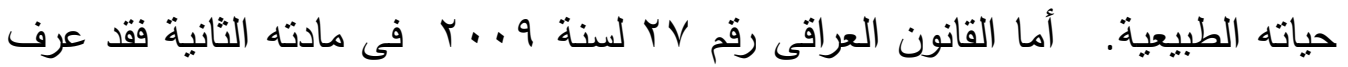


التلوث بإنه وجود الملوثات المؤثرة فى البيئة بكمية أو تركيز أو صفة غيرطبيعية تؤدى بطريق مباشر أو غير مباشر إلى الإضرار بالإنسان أو الكائنات الحية الأخرى او المكونات اللاحياتية التى توحد فيها وهذا التعريف بشمل التلوث الضوضائى باعتبار أن التلوث السمعى يضر بالإنسان بطريق مباشر وغير مباشر . . وعرفة قانون حماية

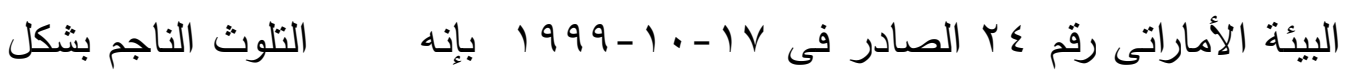
طبيعي أو غير طبيعي ناتج عن قيام الإنسان بشكل مباشر أو غير مباشر ، إرادي أو بإن غير إرادي، بإدخال أي من المواد والعوامل الملوثة في عناصر البيئة الطبيعية، والذي لئي ينشأ من جرائه أي خطر على صحة الإنسان أو الحياة النباتية أو الحيوانية أو أذى الذى للموارد والنظم البيئية ومن استقراء هذالتعريف يمكن القول بإن التلوث السمعى يندرج

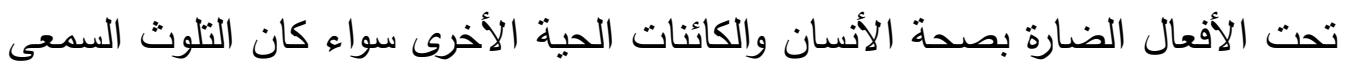
أرادى أو غير أرادى . وعرف المشرع التونسى التلوث فى المادة الثانية من القانون رقم 19 لسنة ra19 بإنه يتمثل فى إدخال أى مادة ملوثة فى المحيط الذى يعيش فيه الإنسان بصفة مباشرة أو غير مباشرة سواء كانت بيولوجية أو كيمياوية أو مادية . وبالنظر إلى هذا التعريف نجد أن التلوث السمعى يدخل فى إطاره باعتباره يمثل خطر وضرر على صحة الإنسان. وعرفه قانون البيئة الكويتى رقم 99 لسنة 10 . ب بإنه كافة الأنشطة البشرية والطبيعية التى تساهم فى تواجد أى من المواد أو العوامل الملوثة

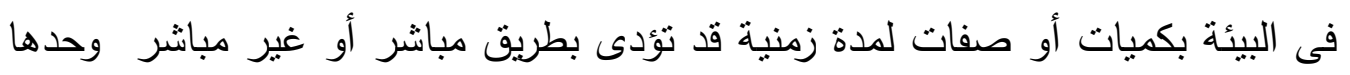

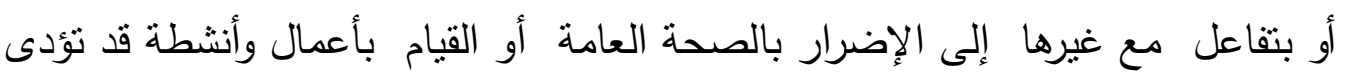

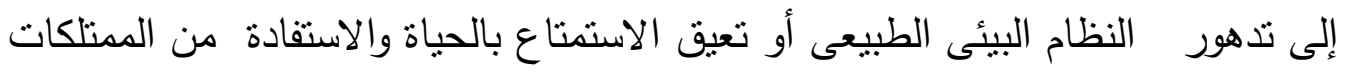

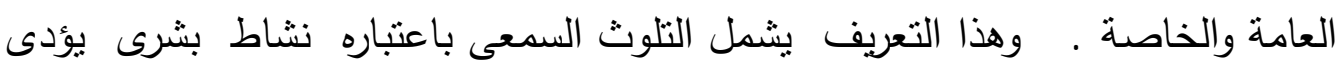

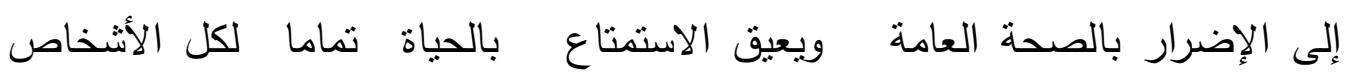

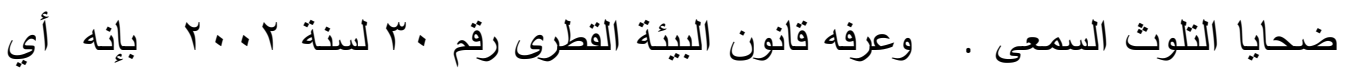
تغيير في خواص البيئة مما قد يؤدي بطريق مباشر أو غير مباشر إلى الإضرار بالكائنات الحية أو المنشآت أو يؤثز على ممارسة الإنسان لحياته الطبيعية وفى الفقه لئه 
وبالنظر إلى هذا التعربف نجد أن التلوث السمعى هوعبارة عن تغيير فى خواص البيئة يؤدى إلى الإضرار بالكائنات الحية ويؤثر على ممارسة الإنسان لحياته الطبيعية .

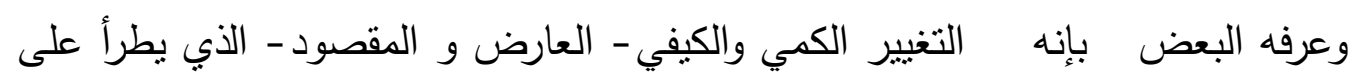
عناصر البيئة المحيطة بالإنسان أوالحيوان أو النبات ويكون من شأنه الإضرار

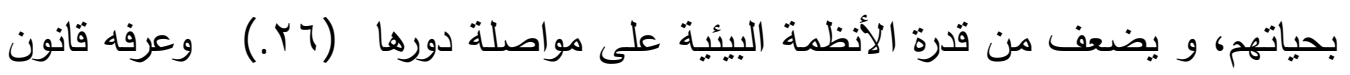

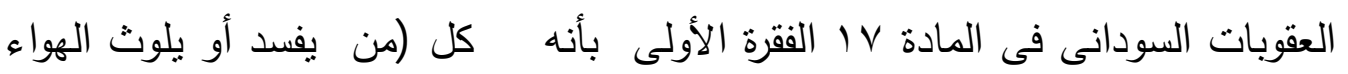

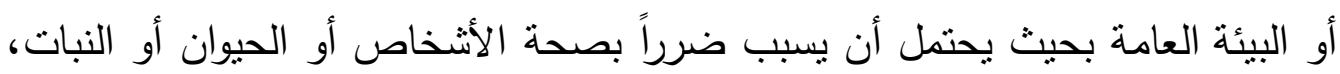

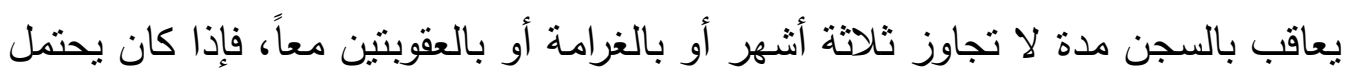

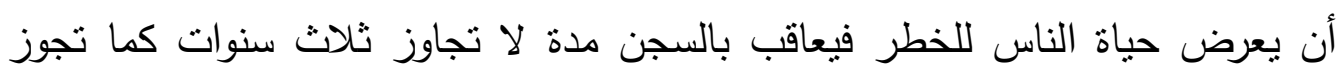
معاقبته بالغرامة ومن سياق هذا النص نجد هذا التعريف ينطبق على التلوث السمعى بـى باهى باعتبار أنه يسبب ضرر بصحة الإنسان والحيوان والنبات. وعرفه رأى أخر بإنه ع عبارة

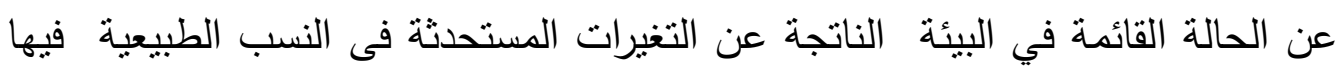
والتي تسبب للكائن الحى الإزعاج أو الأضرار أو الأمراض أو الوفاة بطريقة مباشرة

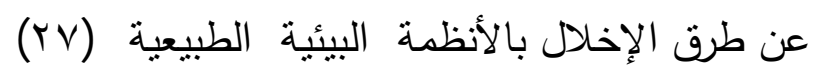
و التلوث بصفة عامة هو بزيادة غير طبيعية فى نسب المواد البيئية بكافة أشكالها المختلفة الغازيّة، أو السائلة، أو الصلبة، أو أحد أشكال الطاقة، التى يستخدمها

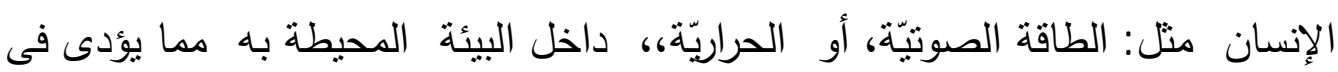

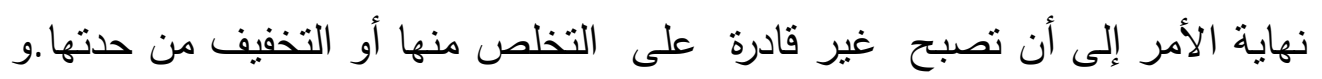
يثير التلوث إلى وجود أو إدخال مواد أو كائنات أو أشكال من الطاقة إلى ركائز أو أو

(YT) -د. نظيمة أحمد محمود سرحان،منهاج الخدمة الاجتماعية لحماية البيئة من التلوث،ط ،دار

الفكر

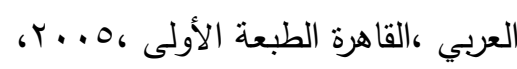

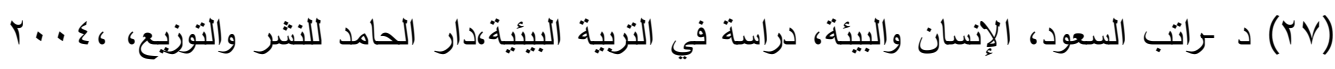
ص or 
وسائط لا نتمي إلبها أو تتجاوز كمياتها النموذجية، لفترة كافية وفي ظل ظروف تسمح بالتدخل في صحة الناس وراحتهم، مما يؤدي إلى الإضرار بالموارد الطبيعية أو تغيير

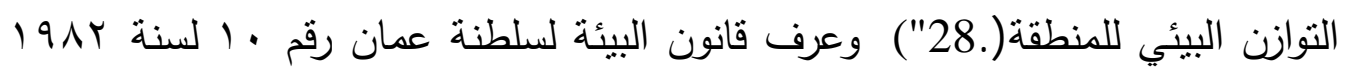
بإنه أى تغيير أو فساد حاد طارىء أو خفيف مزمن فى خصائص النظم والعوامل

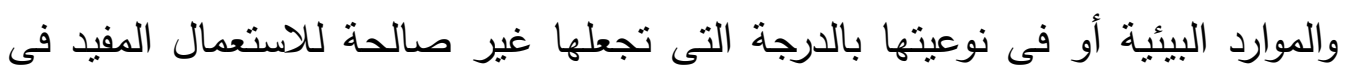

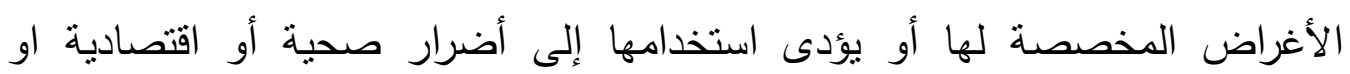

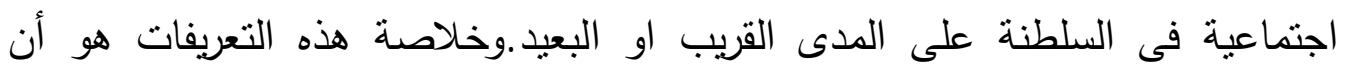

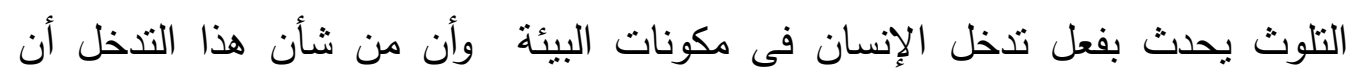
يحدث تغييرات فى الخواص البيئية التى يصاحبها ضرر يلحق بالكائنات الحية التى توجد فى الوسط البيئى ويدخل فيه التلوث السمعى الذى يتضمن تغيرفى خواص البيئة يلحق الضرر بجميع الكائنات الحية.

\section{الفرع الثانى}

\section{التلوث الضوضائى}

من المعلوم أن التلوث لاينحصر فى الهواء أو الماء أو التربة بل توجد أنواع كثيرة من

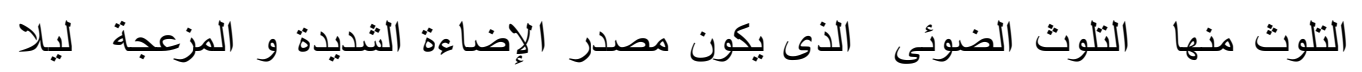
والتلوث الغذائى الذى ينجم عن الاستعمال المفرط فى المبيدات الحشرية التى تستخدم لمكافحة الأفات التى تصيب الخضار والفواكهة .فهو إصابة المواد الغذائية بمادة ضارة Noise Pollution تؤثر من خلالها على صحة الإنسان .أما التلوث الضوضائي

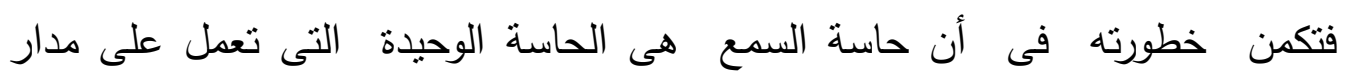

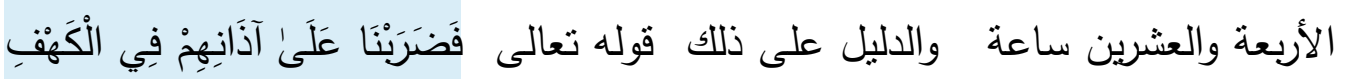

rی)) -Pollution refers to the presence or introduction of substances, organisms or forms of energy to substrates or media they do not belong to or exceeding their typical quantities, for enough time and under conditions that allow interfering with health and comfort of people, damaging natural resources or altering the ecological balance of an area 
سِنِينَ عَدَدًا (Yq) :ومعنى ذلك فضربنا على آذانهم بالنوم في الكهف : أبي ألقينا عليهم

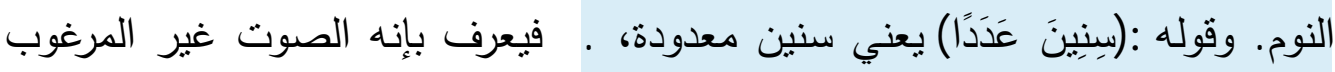
فيه . Noise is defined as unwanted sound والتلوث السمعى يعرف بأنه صوت بدون جودة موسيقية مقبولة أو صوت غير مرغوب فيه. وبالتالي يمكن اعتبار الضوضاء على أنها مجموعة من الأصوات غير المتجانسة أو الاهتزازات غير السارة والمزعجة للأذن. وهو يتضمن جميع مصادر الأصوات المرتفعة المزعجة والمقلقة للراحة وغير المرغوب فيها و التي تصل إلى سمع الإنسان والحيوان، وتتسبب فى في إحداث الكثير من الأضرار للجهاز السمعي والعصبى ل للإنسان والكائنات الحية إلهي الأخرى. و كلمة ضوضاء مشتقة من المصطلح اللاتيني الغنيان. Latin term nausea

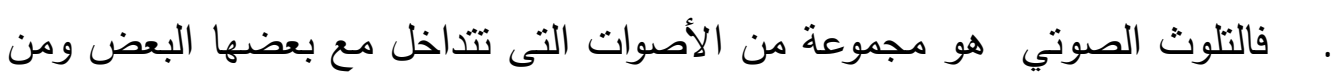
ثم تؤدى إلى شىء من القلق وعدم الارتياح (r) ويمكن اعتبار كل من انبعاث الطاقة

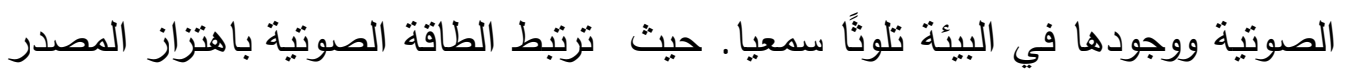
وجزيئات الوسط الذي تتنشر فيه الموجة الصوتية. أو هو مجموع الطاقة الحركية والطاقة

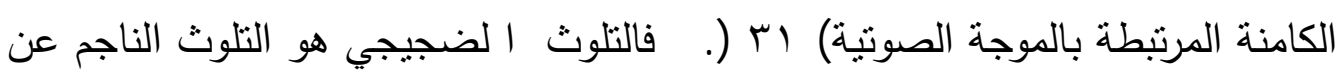
الأصوات العالية التي تصدرها السيارات أو الطائرات، وهو من أثند أنواع التلوث

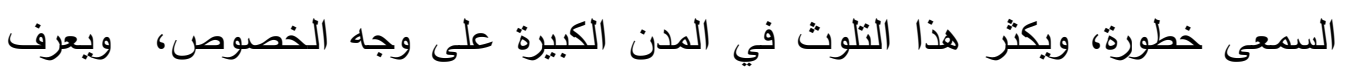

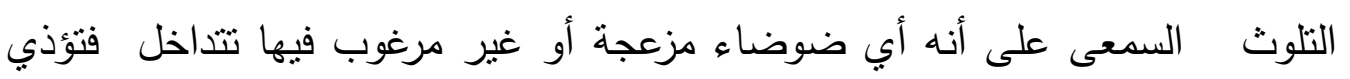

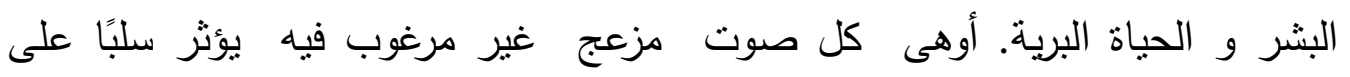
صحة ورفاهية الأفراد أو السكان. على سبيل المثال حركة المرور بالنسبة للسيارات و -

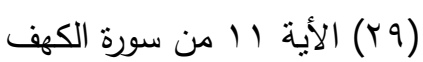

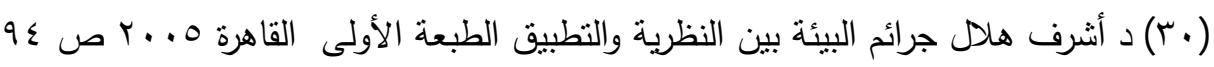

r) Both the emission of acoustic energy and its presence in the environment may be considered pollution. Acoustic energy is related to the vibration of the source and the particles of the medium where the sound wave propagates. It is the sum of the kinetic and potential energy related to the acoustic wave 
محركات الطائرات ويمكن لنا تعريف التلوث السمعى أوالضوضاء البيئية بأنها الضوضاء المنبعثة من جميع المصادر الصوتية بما فى ذلك أماكن العمل الصناعية كالمواقع الصناعية والورش بو مكبرا ت الصوت التى تعد من ابرز مصادر الضوضاء حيث يستخدمها الباعة المتجولين للتروبج عن بضائعهم. أوالمرشحين في الاتتخابات أو أو في المدارس بشكل يقلق راحة البيوت المجاورة لها،. و المشروعات الصناعية والتجارية وورش إصلاح السيارات واللحام وغيرها من المحلات المقلقة للراحة التي تهدد حياة الناس وده وتكدر راحتهم خاصة التى تكون ملاصقة للأماكن السكنية و ألات التتبيه فى الشوارع.

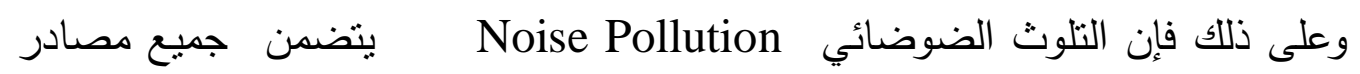
الأصوات المرتقعة المزعجة والمقلقة للراحة وغير المرغوب فيها التي تصل إلى سدع

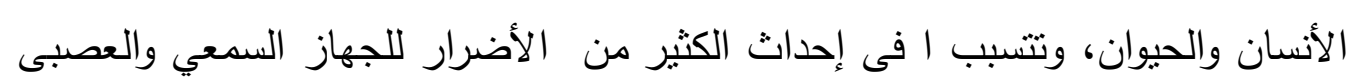

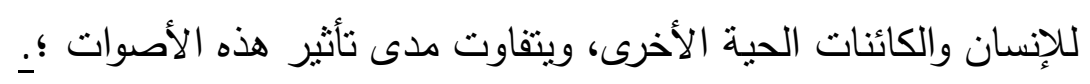
فقد ينتج عنها ضرر مباشر بالأننين، كما هو الحال فى الأصوات التى تصاحب الانفجارات، وصوت الطائرات فى حين تتسبب بعض الأصوات، مثل: الاستماع

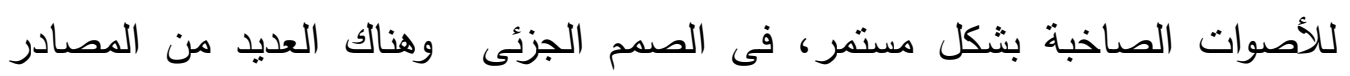

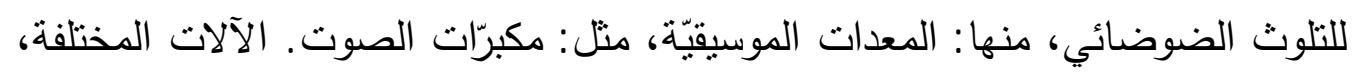
مثل : المكانس الكهربائيّة وجزازات العشب، والآلات والمعدات الصناعية. وسائل النقل مئل المختلفة، منل : الثاحنات، والطائرات، والحافلات، وغيرها . يتسبب التلوث الضوضائي

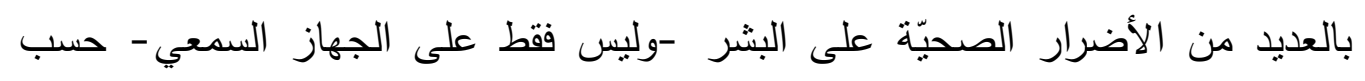

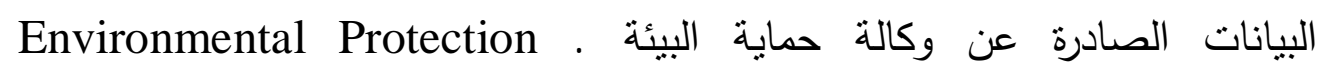

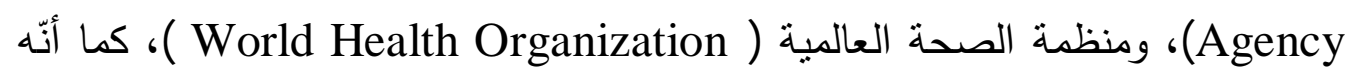
يُعدّ واحداً من المشاكل الصحيّة العامة ذات الوتيرة المتزايدة حسب بيانات مراكز السيطرة على الأمراض والوقاية منها Centers for Disease Control and Prevention )، حيث يؤدي إلى ضعف السمع، وارتفاع ضغط الدم، والصّداع، وتداخل

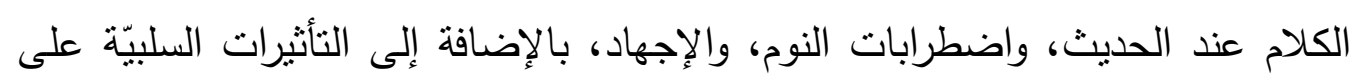

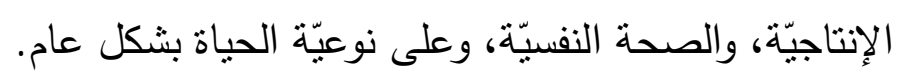




\section{المطلب الثانى}

\section{مصادر التلوث السمعى}

يمكن تصنيف مصادر التلوث الضوضائي على نطاق واسع إلى فئتين : أولا المصادر الصناعية

مثل الضوضاء الصادرة عن العمليات الصناعية المختلفة في المدن، كالغلايات، والآلات، والمسابك، ومطاحن الدقيق، وآلات القطع، والورش الحرفية ومصانع الطائرات

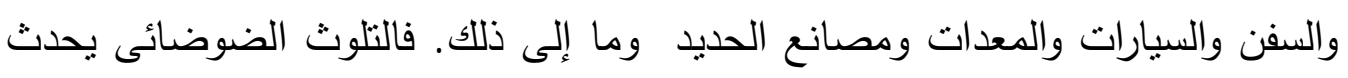
بسبب عمل الماكينات الكبيرة بسرعة عالية. ثانيا المصادر غير الصناعية أو الطبيعية يمكن تقسيم المصادر غير الصناعية للتلوث الضوضائي إلى الفئات التالية: (1) مكبرات الصوت: تعتبر أحد العوامل الثائعة التي تسبب التلوث الضوضائي كالاستخدام العشوائي لمكبرات الصوت،و لا تكتمل أي وظيفة أو احتفالات بدون متحدث

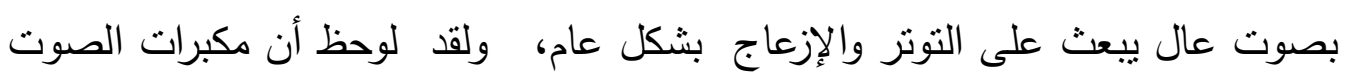
تسبب إزعاجًا كبيرًا للجمهور أثثاء ساعات النوم. و في بعض الإعاج لئاسبات، يؤدي الاستخدام المستمر لمكبرات الصوت إلى إزعاج الطلاب أثناء فترات الامتحان كذلك

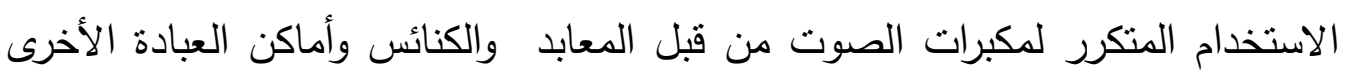
إلى زيادة التلوث الضوضائي وتزايد حدوثه يومًا بعد يوم و بنطلق مكبرات الصوت أيضًا ضوضاء عالية من قبل العديد من الأشخاص والمجموعات والثركات لترويج منتجاتهم (Y) وسائل النقل المختلفة البرية والبحرية والجوية: فوسائل النقل الجوية تعتبر من أثد

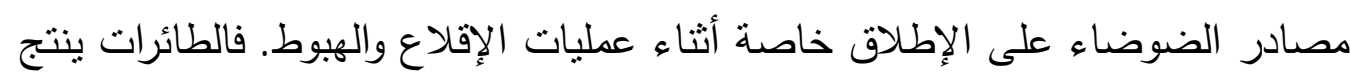

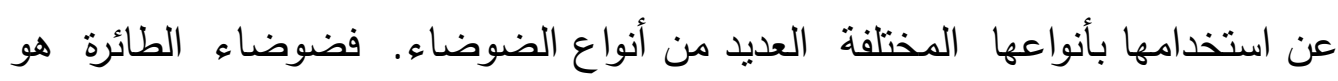

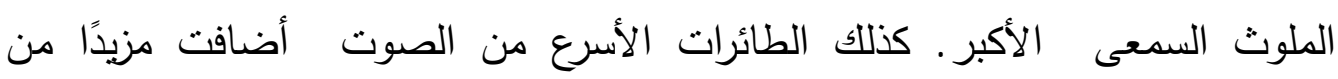
الضوضاء خاصة للسكان للذين يقطنون بالقرب من المطارات. حيث يمكن للضوضاء 
الصادرة عن هذه الطائرات أن تكسر ألواح النوافذ وتشقق المبانى . ولذلك حظرت المدن الكبرى في جميع أنحاء العالم الرحلات الجوية ليلاً لمنع المواطنين من الاضطرار

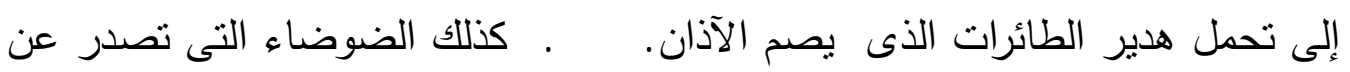
السفن كصوت المحركات وأصوات الأبواق ولايتأثز بهذه الضوضاء إلا الأثخاص اللذين

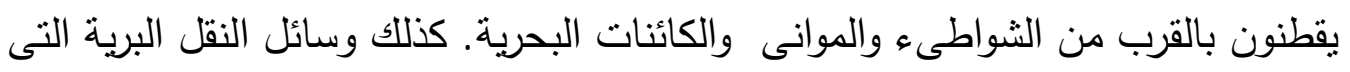

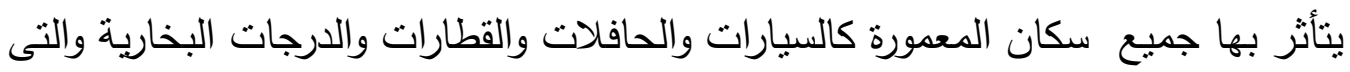
تتواجد فى جميع الثوارع والطرقات على مدار الساعة.أضافة الى استخدام ألات النتبيه المستمر ليلا ونهارا. والسيارات تشكل أكبر مجموعة منفردة من مخاطر الضوضاء.

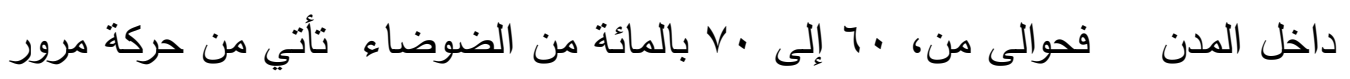

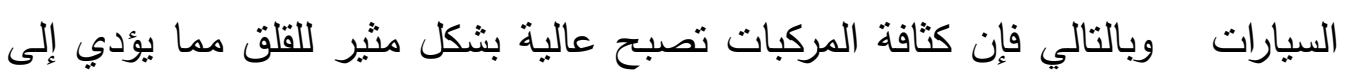

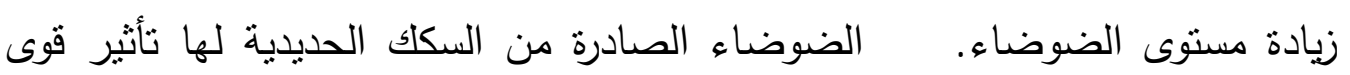
فمحكات القاطرات والأبواق والصفارات وعمليات التبديل والتحويل في ساحات السكك الحديدية نؤثر على المجتمعات المجاورة وعلى عمال السكك الحديدية. على سبيل المثال، يمكن أن تتتج عربات السكك الحديدية صريرًا عالي التردد وعالي

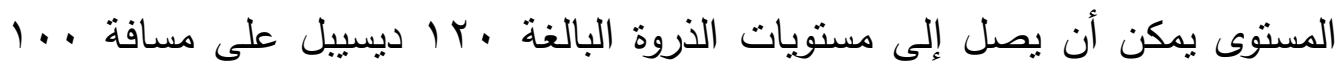

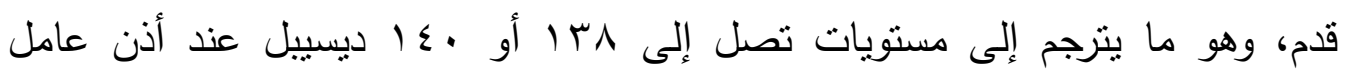

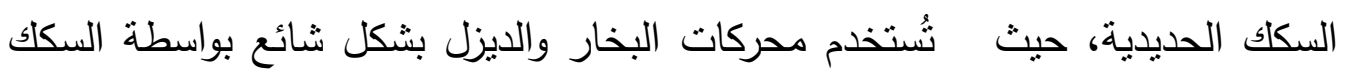
الحديدية التي تتتج الكثير من الضوضا وتأثير التلوث الضوضائي بواسطة القطارات يصل للزروة في المناطق السكنية مع استخدام القطارت السريعة،كل ذلك يؤدى إلى بلى بلى بلى زيادة الضوضاء بشكل كبير

(r) أعمال البناء :، يتطور التحضر بسرعة كبيرة ويتم تثبيد المباني الضخمة بأقصى

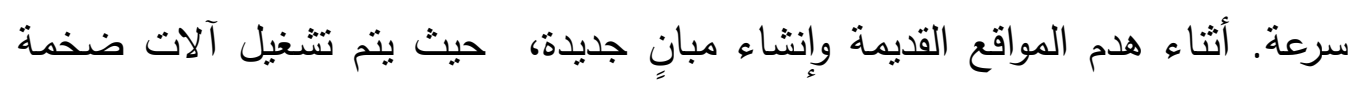
تتتج الكثير من الضوضاء وأصبحت مشهدًا شائعًا في كل مدينة كبيرة حيث تجري أعمال البناء. يحدث الكثير من الضوضاء أثناء أعمال إنثاء أو إصلاح الطرق في المدن 
(ع ) الراديو والألات الموسيقية والميكروفونات : يمكن أن يتسبب الراديو

والميكروفونات في تلوث ضوضائي إذا تم تشغيلهما بمستوى صوت مرتفع حيث . يتسبب لريب الاهتمام الحالي بالموسيقى الغربية والرقص من قبل الثباب ذوبي الصوت العالي في حدوث ضوضاء التلوث .

(0) إطلاق الأقمار الصناعية في الفضاء: هومصدر جديد للتلوث الضوضائي فالأقمار الصناعية، التى يتم إطلاقها في الفضاء بمساعدة المواد شديدة الانفجار كالصواريخ التى ينتج عنها ضوضاء تصم الآذان في وقت "رفع" القمر الصناعي .حيث يتم استخدام طن من مادة تي إن تي والمتفجرات الأخرى في تلك العمليات التي تسبب تلوث ضوضاء على درجة كبيرة جدا

(6) أنشطة التعدين : حيث يكون المصابون بها من عمال المناجم و هؤلاء الذين

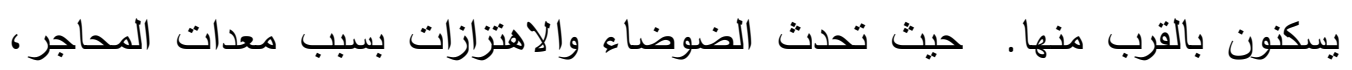
وحركة التربة التقيلة والآلات وعمليات التفجير . 


\section{المطلب الثالث}

\section{الأثار الضارة للتلوث السمعى}

لطالما كانت الضوضاء مصاحبة للحضارة الإنسانية، لكنها لم تكن أبدًا واضحة جدًا،

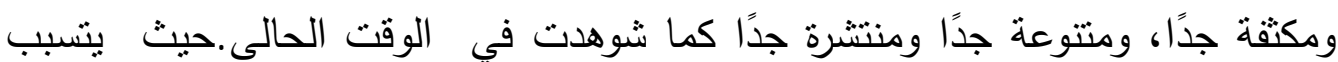
التلوث الضوضائي في زيادة سرعة قلق وتوتر و تهيج الأشخاص . وتأثنير التلوث

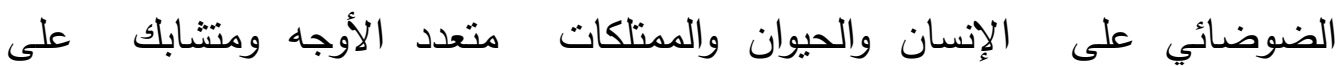

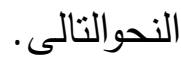
- أولا: موت الإنسان: ولقد كان السبق للقراءان الكريم في الإخبار بموت الإنسان من

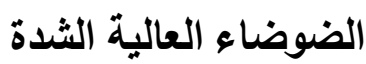
من خلا الحقائق التى خلصت إليها الأبحاث والدراسات العملية والعلمية - في ضوء ما سبق - عن تأثنر الضوضاء على حاسة السمع (الأذن) الذى قد يؤدى إلى تلفها أو تمزقها، وقد يصل الأمر إلى الوفاة، فإنه مما يشرف الإسلام أنه أكد على ذلك منذ ما يربو على أربعة عشر قرناً، في إطار مما ذكر بالقرآن الكريم عن الهلاك بالصيحة؛ فقد بين الله عز وجل طريقة إهلاكه للقوم الكافرين بقوله تعالى " وإن كانت إلا صيحة واحدة فإذا هم خامدون".(Y))، وقوله عز وجل "وأخذ الذين ظلموا الصيحة فأصبحوا في ديارهم

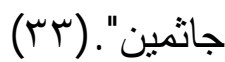

كما أن القرآن الكريم - في إطار ترسيخ ذلك المفهوم - لم يكتف بذكر الصيحة فحسب، بل أشثار إلى الهلاك بالصوت المدوى تحت أوصاف ومسميات أخرى مثل:

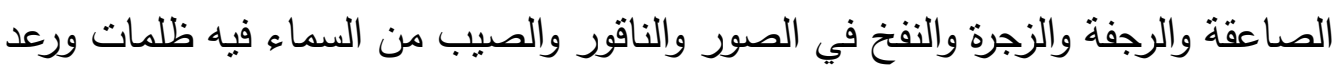

(32) سورة بس، الآية رقم وب. كما يقول اله عز وجل في ذات السورة " ما ينظرون إلا صيحة واحدة

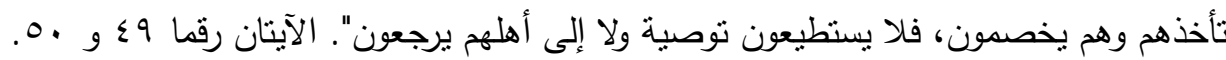
(33) سورة هود، الآية رقم VT لآ. 
وبرق يجعلون أصابعهم في آذانهم من الصواعق حذر الموت. كل هذه المسميات أمعن في الد لالة على مدى ما يحدثه الصوت البالغ الثدة من هلاك وضرر للأنسان والحيوان. ثانيا:تقلل من كفاءة الإنسان : - فيما يتعلق بتأثير الضوضاء على الكفاءة البشرية، هناك عدد من التجارب التي توضح حقيقة أن الكفاءة البشرية تزداد مع تقليل الضوضاء. وأثتتت الدراسات أن شدة التلوث السمعى تقلل من قدرة الشخص على إنجاز مهامه

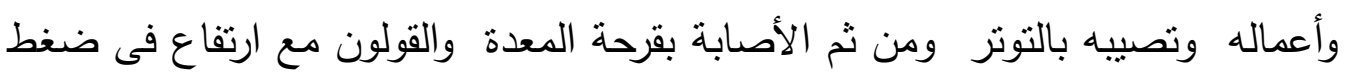

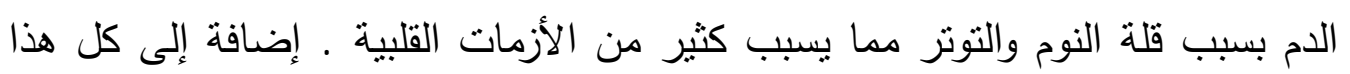

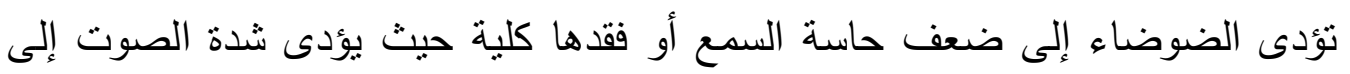
تلف الأذن الداخلية فيحدث الصمم التام للشخص (عץ) ولقد اقترحت دراسة أجرتها في الهند أن تقليل الأكثاك الصناعية ومن ثم تقليل الضوضاء

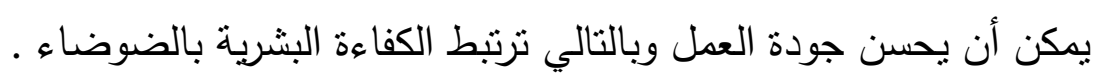
ثانيا قلة التركيز : لتحسين جودة العمل يجب أن يكون هناك تركيز، والضوضاء تسبب نقص التركيز . في المدن الكبرى، تقع جميع المكاتب الرئسية في الغالب على لئ الطريق الرئيسي. ومع ضجيج حركة المرور و مكبرات الصوت لأنواع مختلفة من الأبواق كل ذلك يصرف انتباه الأشخاص العاملين في المكاتب. وفى مجال التعليم نقلل الضوضاء من تركيز الطلاب وتضعف إلى حد كبير من استيعابهم للاروس والمعلومات التى يتلقونها داخل المدرسة.

ثنالثا التعب الثنديد والإرهاق: - بسبب التلوث الضوضائي، لا يستطيع الناس التركيز.

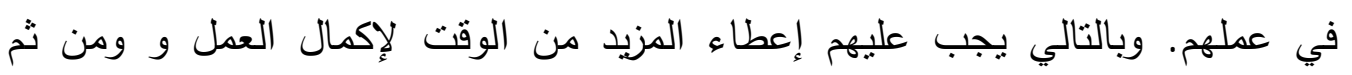
يشعرون بالتعب.

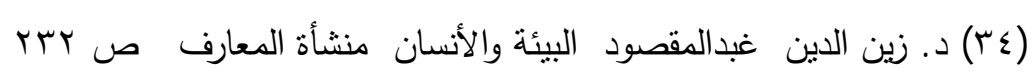


رابعا حدوث الإجهاض : - يجب أن يكون هناك جو بارد وهادئ أثناء الحمل. الأصوات غير السارة والصاخبة تجعل السيدة الحامل متوترة وبالتالى ينعكس ذلك عليها ولقد أثبتت الدراسات أن الضوضاء المفاجئة تنبب الإجهاض للإناث

خامسا: التوتر والقلق والمرض العصبى والنفسى: يتمد تأثير الضوضاء إلى جميع أجهزة الجسم بما فى ذلك الجهاز العصبى والحالة النفسية حيث تلعب الضوضاء دورا كبيرا فى الإصابة بالأمراض العصبية والنفسية وقد أيدت ذلك الأبحات التى أجريت فى

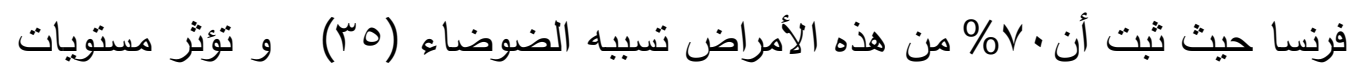

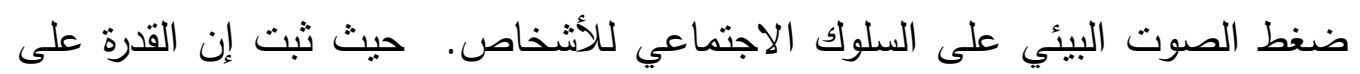
تحمل الضوضاء مرتبطة عكسياً بالعدوانية، فالأشخاص الذين يتعرضون لمستويات الأينات

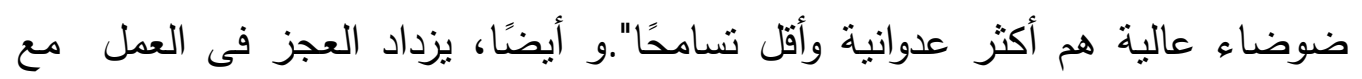

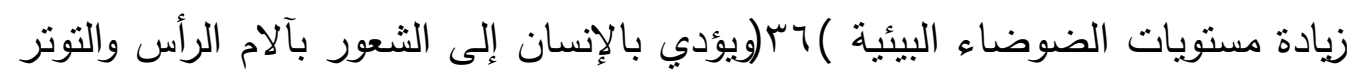
والاضطرابات الفيزيولوجية الأخرى، كما قد يؤدي التلوث الضوضائي إلى الانهيار العصبي أو النفسي في بعض الأحيان إذا وصل إلى درجة حرمان الإنسان من النوم والراحة. فيكون سببا فى في الصداع و عدم القدرة على التركيز و الثرود الذهني

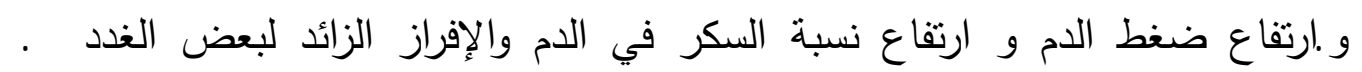

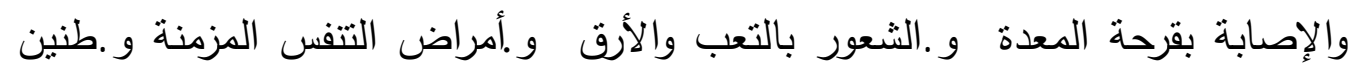
الاذن و.نقص النشاط الحيوي و .القلق وعدم الارتياح الداخلي و.الارتباك وعدم الانسجام

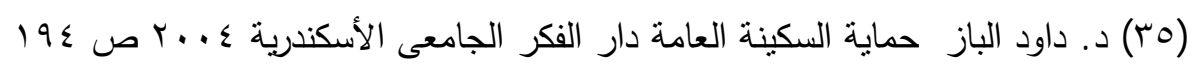
(rч- ) Alice Elizabeth González. What Does "Noise Pollution” Mean? Journal of Environmental Protection, 2014 p 362 ( noise is a social construction which involves a negative social value on certain sounds, so that even music canbe socially considered as noise Environmental sound pressure levels can affect the social behavior of people. The ability to withstand noise is said to be inversely linked to aggression, as stated Vázquez Estivill "People who are exposed to high noise levels are more aggressive and less tolerant". Also, helplessness increases as environmental noise levels do ) 
خامساً: ارتفاع ضغط الدم: - التلوث الضوضائي يسبب أمراض معينة للإنسان . إنه

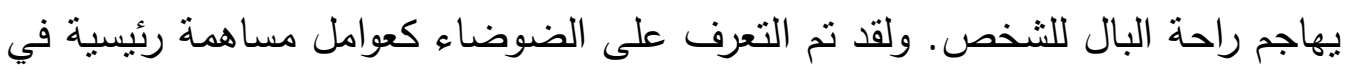
تسريع التونرات الموجودة بالفعل في الحياة الحديثة. حيث تؤدي هذه التوترات إلى

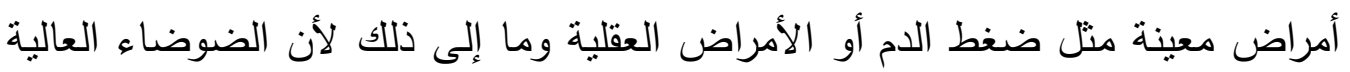
تؤدى إلى حدوث تغيرات فى جسم الأنسان مثل انقباض الثرايين والثعيرات الدموية وزيادة ضربات القلب وتقلص العضلات سادساً: الصمم الأئم والمؤقت: -الصوت المرتفع يؤدى إلى خلل فى وظائف الأذن. والأنف والحنجرة ويؤدى إلى خلل فى الهرمونات ومن ثم حدوث خلل فى وظائف المخ المخ وقلة التركيز فالميكانيكيون وسائقي القاطرات وعمال الهاتق وما إلى ذلك لديهم سمع. ضعف نتيجة الضوضاء في مكان العمل. يرى الفيزيائيون والأطباء وعلماء النفس أن أن

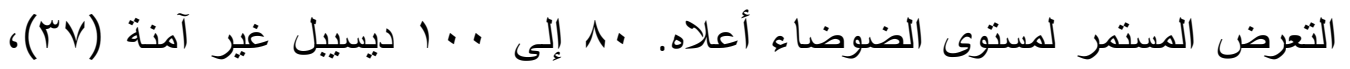
وغالبا الضوضاء الصاخبة تسبب صمًا مؤقنًا أو دائمًا سابعاً: التأثير على الخضراوات: رداءة نوعية المحاصيل: الآن أصبح معروف. للجميع أن النباتات تشبه الإنسان . هم أيضا حساسون منل الأنسان . يجب أن تكون هنالك

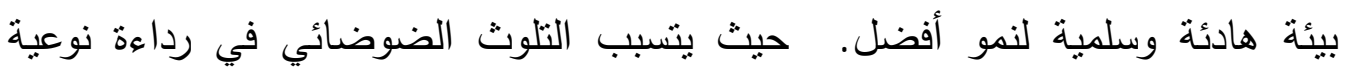
المحاصيل التى تتمو في جو صاخب تحيط به الضوضاء

تثامنا التأثير على الحيوان: -التلوث الضوضائي يضر بالجهاز العصبي للحيوان.

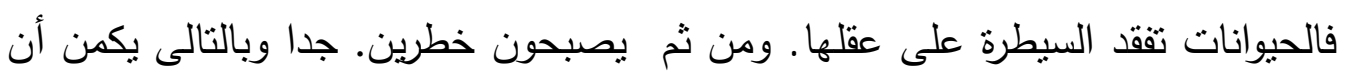
يلحق الضرر بالثخص الذى يتعامل معه

تاسعا على الممتلكات: - الضجيج العالي خطير جدا على المباني والجسور والآثار . حيث تخلق الضوضاء موجات تضرب الجدران وتعرض المبنى للخطر . ومن ثم يضعف صرح الأبنية بسبب الخلخلة التى يحدثها الصوت المرتفع فى المبانى .

$$
\text { (TV) - هى وحدة قياس الصوت }
$$




\section{المبحث الثالث}

\section{أركان جريمة التلوث الضوضائى}

جريمـة التلوث السمعى هى اعتداء على مصلحة يحميها القانون وهى المصالح الصحية والتعليميـة والاقتصادية والاجتماعيـة لـذلك يـرى المشرع أنهـا جديرة بالحمايـة فيتدخل لينقل الفعل المكون لها من نطاق الإباحة إلى نطاق التجريم .و تتمثل إحدى المشكلات المتعلقة بالتلوث الضوضائي في تعدد السلطات المختصة القادرة على ثلقي هذا النوع من الشكاوى من المواطنين المتضررين، مما يساهم في خلق مناخ عام من الإفلات من العقاب للكيانات المخالفة.

على سبيل المثال: (أ) عندما يأتي التلوث الضوضائي من نشاط كيان تجاري أو

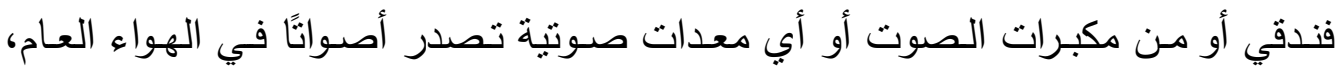
تكون السلطة المختصة هي إدارة الشرطة المحلية أو الوطنية ؛ (ب) عندما يأتي التلوث

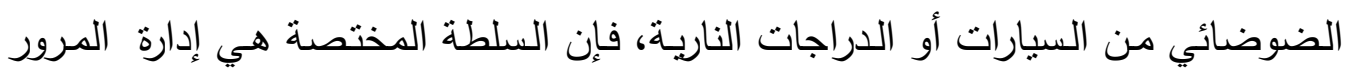
التـابع للشرطة العامـة أو إدارة المـرور بالـشرطة المحليـة ؛ (ج) عنـدما يـأتي التــوث الضوضائي مـن الطـائرات، فـإن السلطة المختصة هـي الإدارة العامـة للطيـران المـدني والمطارات والملاحة الجوية (شركة عامة) ؛ (د) في حالة وجود التلوث الضوضائي في إن أي مكان عمل، فإن السلطة المختصة هي التقتيش العـام للعمـال ؛ (هـ) وعندما يـأتي التلوث الضوضائي من أبي نوع من الأعمال، فإن السلطة المختصة هي الإدارة العامـة

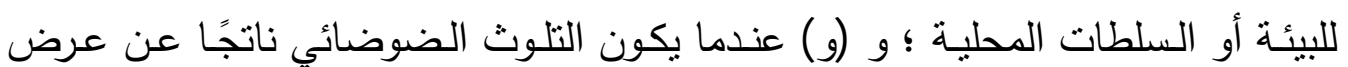
عام أو ديسكو /رقص، فإن السلطة المختصة هى الثرطة. و حتى يتدخل المشرع بالتجريم لابد وأن يلحق الفعل ضرر بحق أومصلحة برى

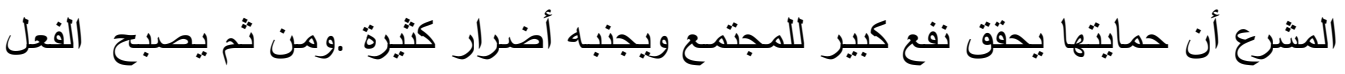
يشكل جريمة بعد تدخل المشرع بالنص عليه وإخراجه من نطاق الإباحة والمشروعية إلى نطاق التجريم . فالجريمة هى كل فعل غير مشروع صـادرعن إرادة جنائية يقرر لله القانون 
عقوبة أو تدبيرا احترازيا .(r ) فهى سلوك يتضمن اعتداء على مصلحة محمية يحددها المشرع سلفا بنص مكتوب أو يعرضـها للخطر مـع صدور السلوك عن إرادة حرة واعيـة وأثنـة ويقرر لـه القـانون جزاء جنائيـا يستوفى باسـم المجتمـع مـن خـلال قنوات جنائيـة

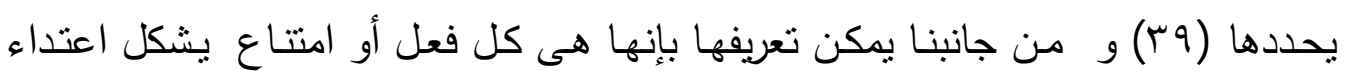

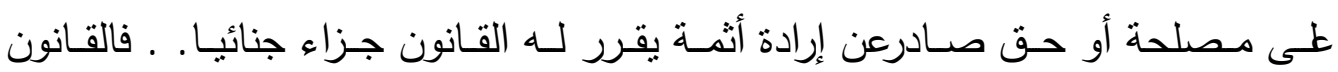
الجنائى فى ظل السياسة الجنائية الحديثة لا يقتصر دوره على العقاب، فقط بل لله وظيفة

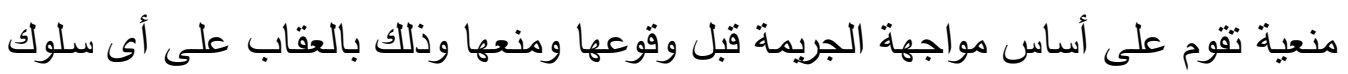
سلبى أو إيجابى ينطوى على تعريض الغير للخطر بمخالفـة نص قـانونى أو لائحى، والذى يسفر عن حدوث ضرر للحق أو المصلحة التى يحميها القانون، وهى مرحلة وسط ما بين الخطأ والعدد فهى تبدأ حيث ينتهى الخطأ غير العدىى وتتتهى حيث يبدأ العدد.

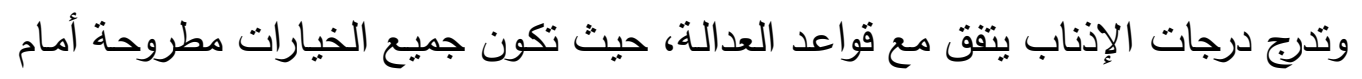

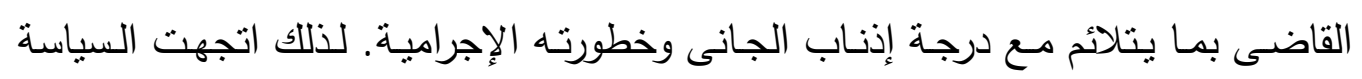

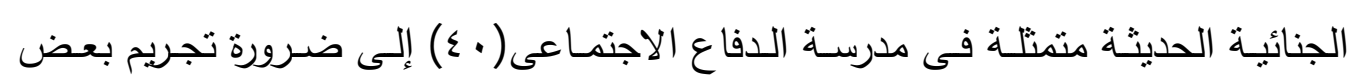

(†^) -د، محمود نجيب حسنى شرح قانون العقوبات القسم العام الطبعة السادسة دار النهضة العربية \& 1919

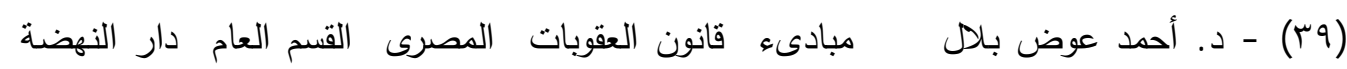

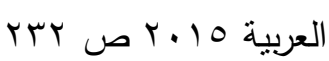

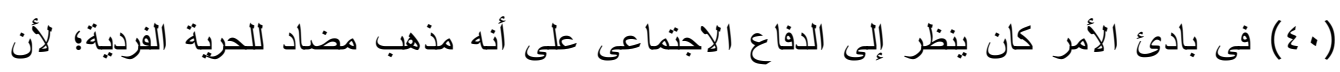

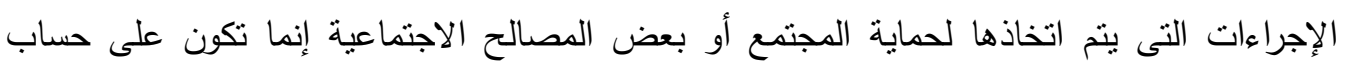

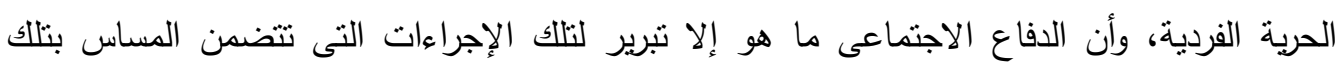

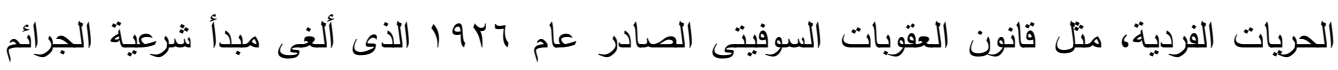

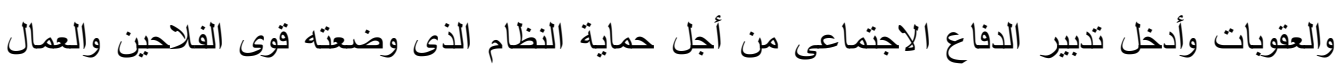

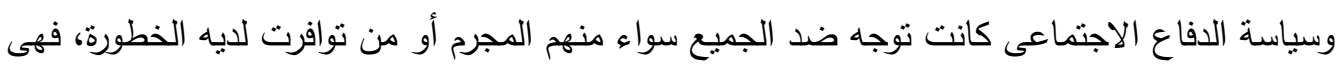

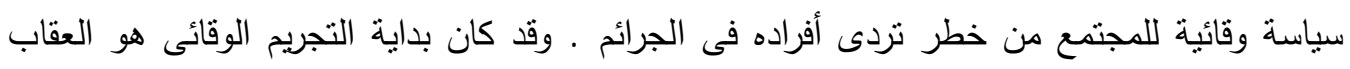

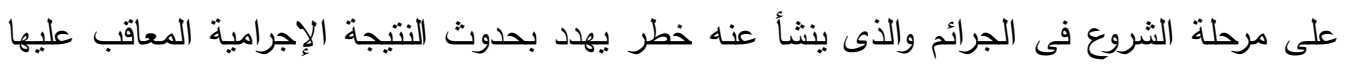
لكن الفارق ما بين الثروع والجريمة التى نحن بصددها يكمن فى أن الثروع تتجه فيه إرادة الجانى نحو لأني 
أنماط السلوك الخطر، حيث دعا إلى ذلك المبدأ المؤتمر الدولى العاشر لقانون العقوبات

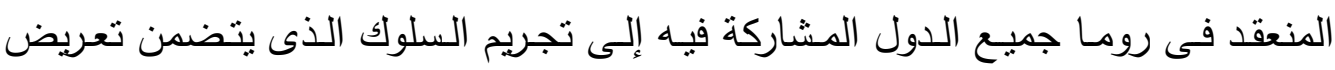

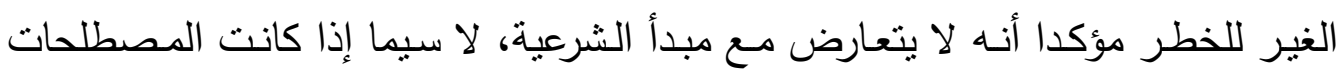

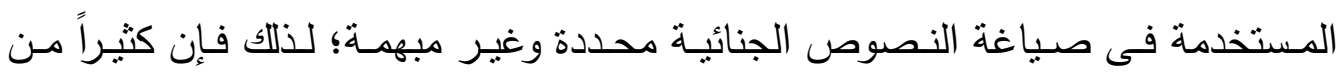
التشريعات الجنائية قد نصت على تجريم تعريض الغير للخطر ، باعتبارها جريمـة قائمـة مستقلة بذاتها، كالقانون السويسرى تحت مسمى جرائم الخطر جرائم المنع les infraction de prévention وهى جرائم شكلية يجرم المشرع فيها أنماط السلوك التى يتولد عنها خطر أو تخلق خطراً ينذر بوقوع ضرر

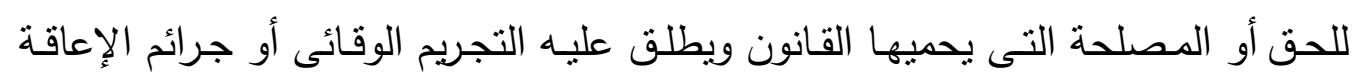

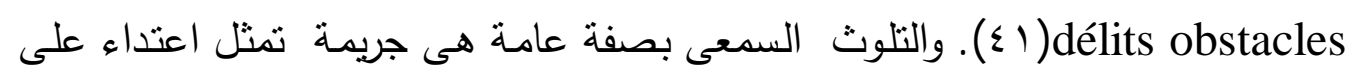

إحداث النتيجة الإجرامية إلا أنها لا تحدث بسبب خارج عن إرادة الجانى فى حين أن إرادة الجانى فى إنى

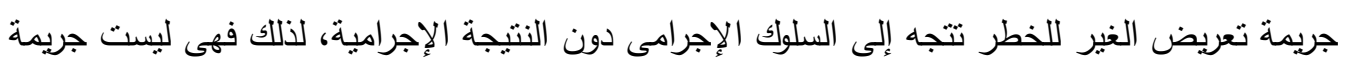
عمدية.

le port d'arme prohibe ومن أمتلة الجرائم المنعية أو الوقائية كذللك الحيازة المحظورة للسلاح والتشكيلات العصابية les ménaces والتهنية lessociation de malfaiteurs بارتكاب جريمة. وبالإضافة إلى الجرائم العدية كالسابق ذكرها فإنه توجد جرائم منعية غير عمدية مثال ذلك القيادة فى حالة سكر أو تحت تأثير كحوليات.

Conduite en état d'ivresse ou sous l'empire d'un état alcoolique.

لكن هذا التجريم المنعى أو الوقائى بنظم بعض أنماط سلوكية معينة لكن سياسة التجريم المنعى

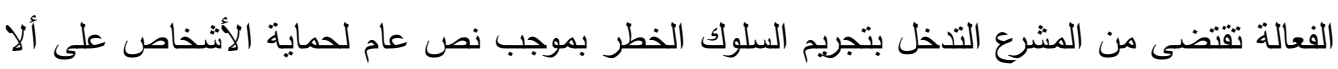
يتعارض ذلك مع مبدأ الثرعية وحقوق الأفراد .

(§) Veron (M.), Droit pénal spècial 7 éme éd Armand colin, 1999, P. 88; Merle (R.) et Vitu (A.), Traité de droit criminal t.I. Droit penal général 6 éme éd Cujas (Paris) 1984, No. 1820. P. 1463; Couvrat (P.), l'imprevoyance, dans le droit pénal des loisirs sous la présidence de a chavanne édition cujas 1990. P. 171.

وراجع جريمة التعريض لخطر حدوث الموت والجرح فى كل من القانون السويدى

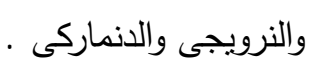


السلامة البدنية والصحة النفسية والاجتماعية والتعليمية والاقتصادية ونتكون الجريمة من

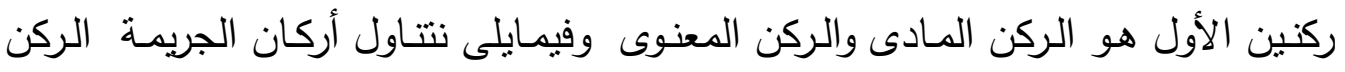
المادى (الفرع الأول ) والركن المعنوى (الفرع الثانى) على النحوالتالى:

\section{المطلب الأول}

\section{الركن المادى لجريمة التلوث الضوضائى}

لا يمكن بـأى حال من الأحوال مساءلة الجانى عن جريمـة لمجرد انصراف تفكيره إلى ارتكابها؛ لأن القانون الجنائى يقوم على مبدأ أساسى، وهو لا جريمـة إذا لم يخرج هذا

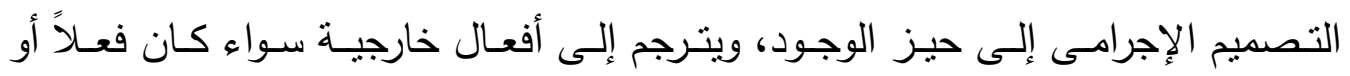

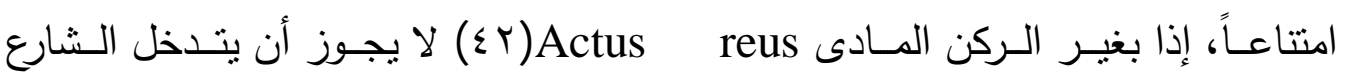

Ancel (M.) et Strahl (I.) : le droit pénal des pays scandinaves les édition de l'epargne Paris, 1969, No.55 P.77; Sur le delit - obstacle voir Ayache (A.B.), Dictionnaire de droit pénal général et procédure pénal ellipses édition 2001.P. 55.

(؟Y) د د ـ محد أحمد مصطفى أيوب: النظرية العامة للامتتاع فى القانون الجنائى، رسالة دكتوراة،

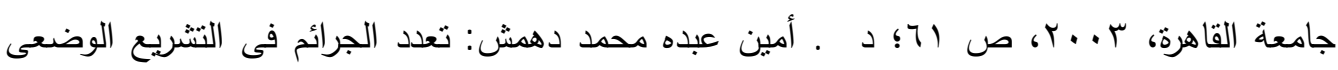

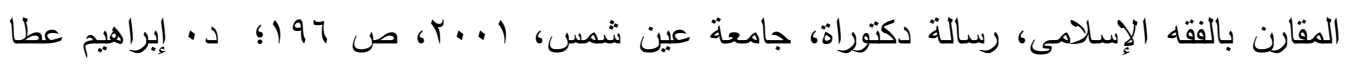

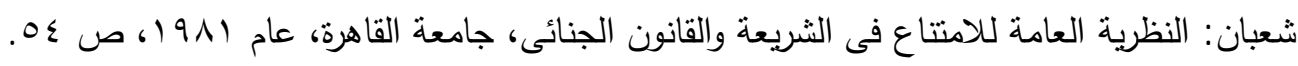
Actus Reus المحاكمة القانونية

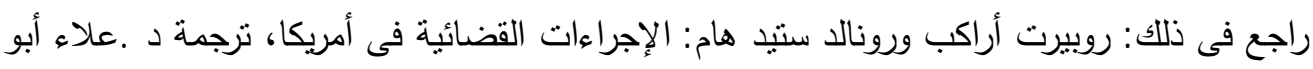

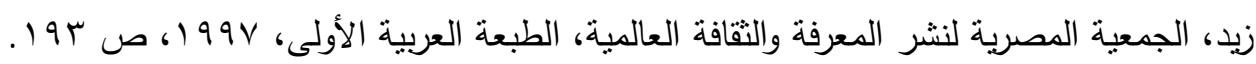
Actus reus states of affairs ونتائجه its results Conduct

L.B. Curzan: criminal law seventh edition longman 1994. P. 24. 
Man can ot be convicted of crime without certain event فلا or certain state of Affairs which is Forbiden by the criminal law.

جريمـة بغير سلوك No Actus reus No crime فالسلوك الإجرامى Nonimal conduct التنفيذ Le commencement d’exécution، ولا يمكن القول بأن الاعتقاد الإجرامى الإجى الإعى من شأنه أن يشكل اعتداء على المصالح والقيم المحمية، فلقيام المسئولية الجنائية تجاه المتهم يتعين إسـاد الجريمة ماديا إليه، أو بمعنى آخر قيام علاقة ماديـة مـا بين المتهم Le lien de والنتيجة الإجراميـة، وهو مـا اصطلح على تسميته برابطة السبيية causalite

وتتكـون عناصـر الـركن المـادى للجريمـة مـن السلوك الإجرامسى الــادر عـن شخص المتهم؛ حيث يتخلف عنه آثار مادية فى العالم الخارجى، وهى ما يطلق عليها النتجة الإجرامية التى تربطها بالسلوك الإجرامى رابطة السبيية، سواء كان ذلك السلوك

\&r) Smith and Hogan on criminal law Fifth Edition Butterworth, 1983, P. 31 Merle (R.) et Vitu (A.) : Traite de Droit Criminel t. I droit Penal general Eion Cujas sixieme Paris éd, 1984 No 450. P. 575.

Corps du Delit يث يطلق على الركن المادى

R Assat (M.L.) : Droit Pénal P.U.F. 1987 No. 236. P. 339 et No. 237 P. 340 et Vidal (G.) et Magnol (J.) :Cours de droit criminel et de sience péntitentiare, Paris, 1928. P. 142. No. 95 et 96 .et G Arraud (R.) : traite theorique et pratique du Droit Penal Francais t. I. 3 éme éd Surey 1913 No. 223. Soyer (J.C.) : Droit pénal et procedure pénale 19 edition L.G.D.J. 2006, P. 58.

(§؟) د. عبد الفتاح مصطفى الصيفى: الاثشتراك بالتحريض ووضعه من النظرية العامة للمساهمة

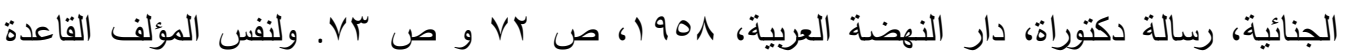

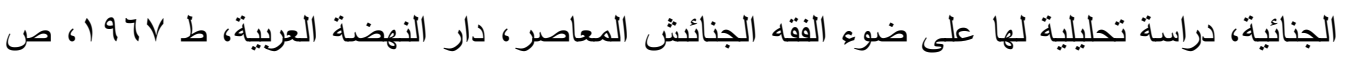
$. \vee \leqslant$

يطلق بعض الفقه على السلوك الإجرامى لفظ الحدث الإجرامى باعتبار أنه فى معظم حالاته يتبع

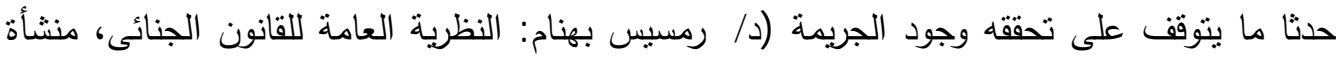

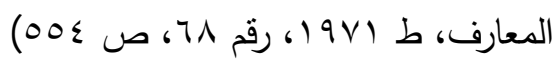


الإجرامى فعلا أو امتتاعا An Act or an omission وبالنسبة لجريمـة التلويث الضوضائى، فهى اعتداء على مصصالح صـحية واجتماعيـة وتعليميـة واقتصادية هامسة

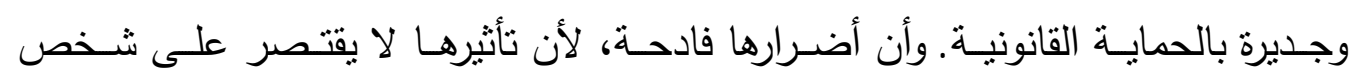
معين، بل تصيب المجتمع كله . بل.

وقد يشكل ذلك السلوك المجرد فى حد ذاته جريمـة معاقب عليها، هى ما يطلق

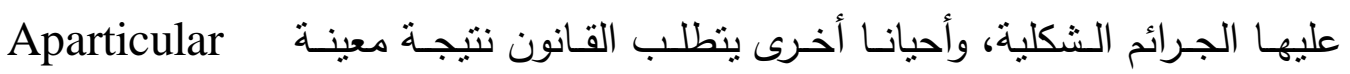
consequence or result ويتفق ذلك مـع اتجاهات السياسة العقابيـة الجديدة التى تقوم على تجريم السلوك الخطر

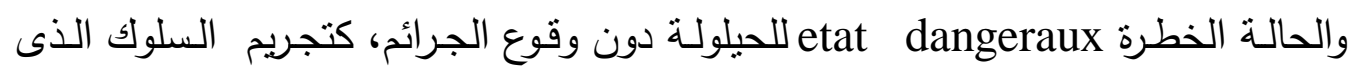
يولد الضوضاء وتعريض الغير للخطر ،، وذلك لا يشكل اعتداء Assault على حربـة

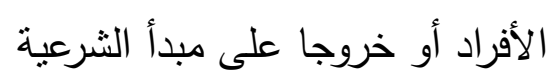

وفيما يلى نتكلم عن السلوك الإجرامسى فى جريمـة التلوث السمعى (الفرع الأول)

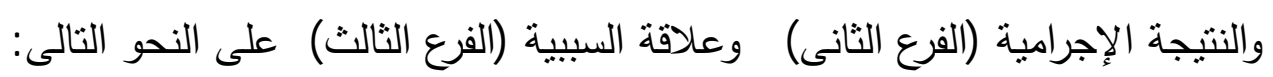

\section{الفرع الأول}

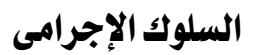

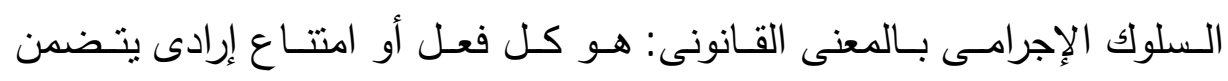

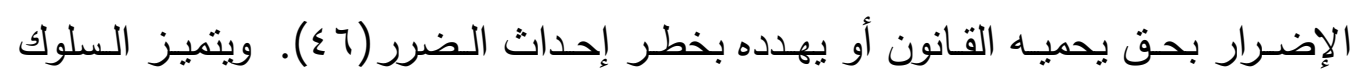

( $८$ ) Michael tmolan and Graeme Broadbent: Criminal law pitman publishing london 1994 P.3

Sayer (J.C.) : Droit penal et procedure penale, 5 éme éd, 1977 Paris No 77. P. 63.

( $₹ 7)$ Catherine elliott and Frances quinn; Criminal law pearson longman 5 éd 2004 P. 9; 10 Janet Dine and James Gobert; Criminal law cases and mterials on criminal law Oxford University press 4 éd 2003. P. 88; William Wilson; Criminal law Doctrine and theory 2 éd 2003. P. 27. = 
الإجرامسى في جرائم التلوث السمعى بسمات معينة تحدد ماهيته وطبيعته وتلعب دورا

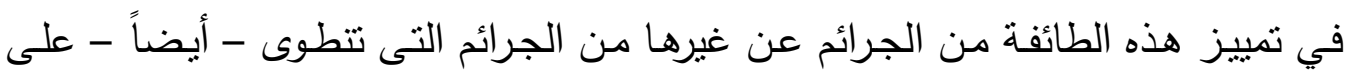

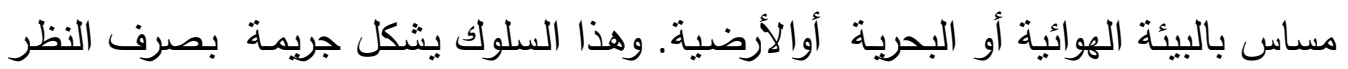

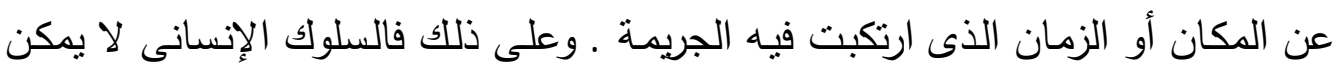

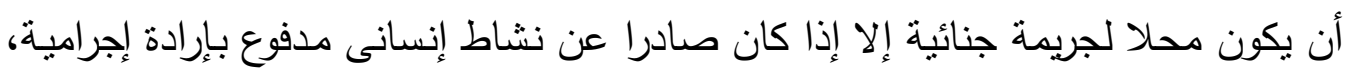

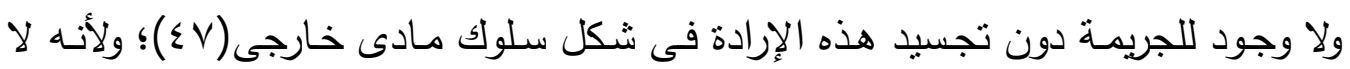
جريمة بغير سلوك إجرامى(^^) ويتتوع السلوك مابين السلوك الإيجابى والسلوك السلبى

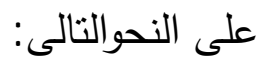

راجع: د ـ محمد محيى الدين عوض: المبادئ الأساسية التى يقوم عليها القانون الجنائى الأمريكى،

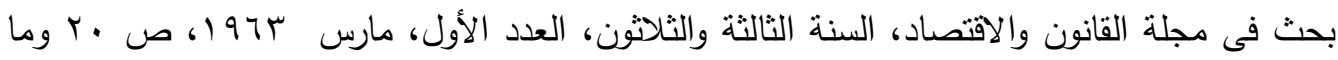

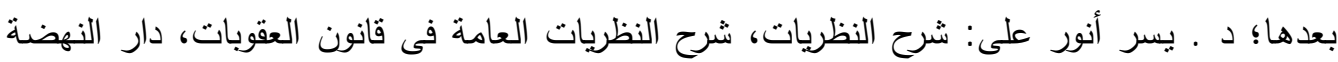

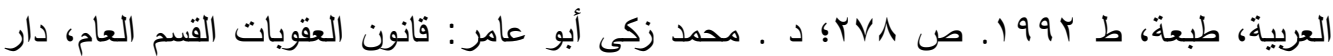

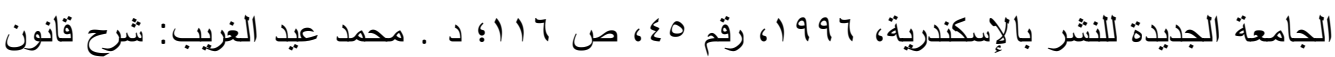

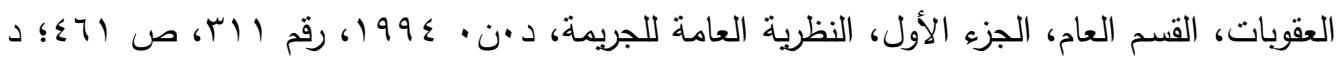

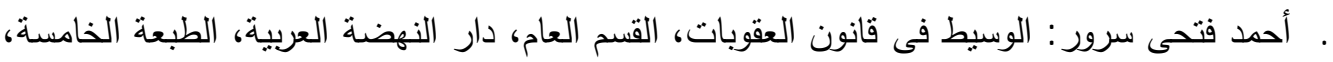

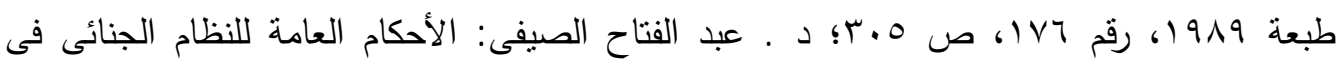

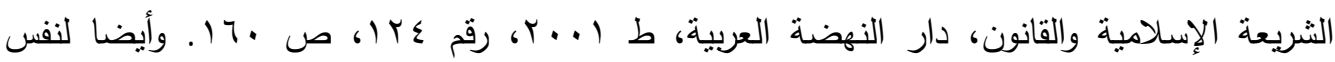

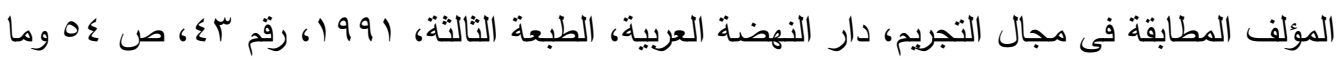

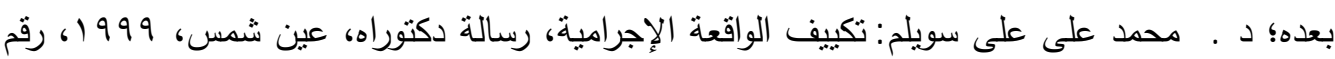

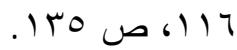

(£₹) Merle (R.) Vitu (A.) Traite de droit criminel t. I. Droit Pénal général 6 éme éd cujas (Paris) 1984., P. 581. Smith and Hogan. Criminal law eleventh edition 2005.., P. 29. William wilson, criminal law doctrine and the theory second edition 2003, P. 72; Catherine elliott and Frances quinn; criminal law fifth edition, 2005. P. 9.

¿^) No Conviction without actus reus; See smith and hogan. Op. Cit., eleventh edition 2005. P. 36. Grispigni: Diritto Penale itoliano Vol 2 No. 6. P. 27. $=$ 


\section{السلوك الإيجابى فى جرائم التلوث السمعى :}

الأصلـ فـى التشريعات الجنائيـة أن المشرع الجنائى ينهى عن ارتكاب فعل أو الإقدام

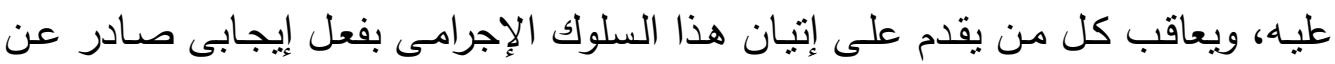

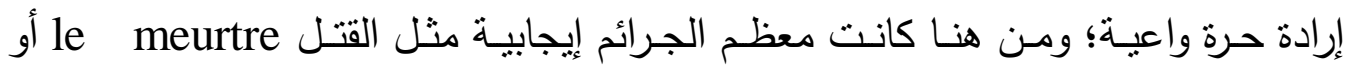
الاغتيال L,assassinat والسرقة والقذف la diffamation coups والجرح Blessures إيجابى يأتيـه الجانى يتمثنل فى إحداث أصـوات شـيدة الصخب ومزعجـة ومـن شـأنها تكدير راحة الناس وإزعاجهم كقيام الباعـة الجائلين باستخدام مكبرات الصوت للإعـلان

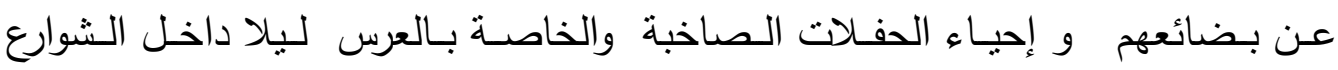
والحارات المكتظة بالسكان مع استخدام مكبرات الصوت والموسيقى الصاخبة حتى وقت

= مشار إليه فى المطابقة فى مجال التجريم للاكتور / عبد الفتاح الصيفى، الطبعة الثانية، دار

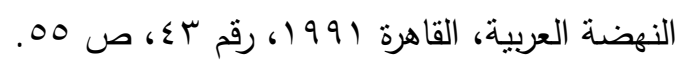

Stefani (G.) levasseur (A.), Bouloc:. driot penal general 13 éme éd. P. 184.

Garraud ( $\mathrm{R}$ traite théorique et partique du droit pénal Francais 3 éme éd Paris T. I. 1931; T. 2.., No. 223 P. 472.

Vidal (G.) et Magnol (J.) , Cours de Droit criminel et de science pénitentiaire Paris, 1928. No 82. P. 143.

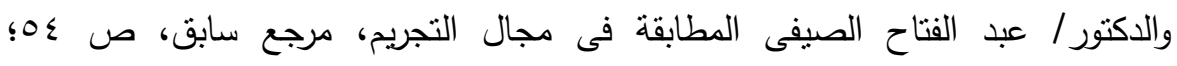

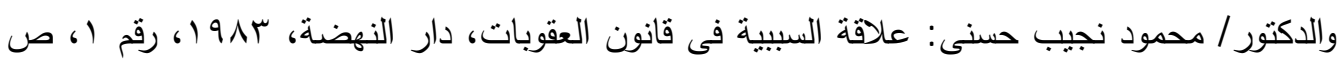

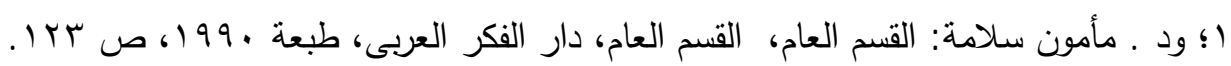

( ₹१) Stefani, (G.), levasseur (G.) et Bouloc (B.), Droit Pénal géneral, 15 éme éd dalloz 1995.., No 215. P. 184. Levasseur (G,), chavanne (A.), montreuil (J.) et Bouloc (B.), Droit Pénal général et procédure Pénale, 13 éme éd Dalloz 1999. No. 73 P. 30. Catherine Elliott and Frances quinn criminal law Op. Cit., P. 8; Ancel (A.) et Srzentic (N.) ; les grands systémes de droit pénal contemporains; le droit pénal nouveau de la yougoslavie; les éditions de 1'Epargne. 1962. P. 38.

ود/ مأمون سلامة، مرجع سابق، ص بr ا، داعلى راشد: القانون الجنائى، المدخل وأصول

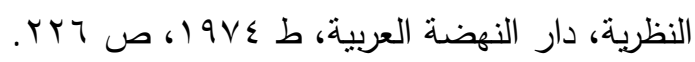


متأخر من الليل .وتشغيل الألات والمعدات ومكبرات الصوت بطربقة تتجاوز الحدود

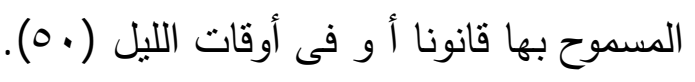
ففى البرتغـال جاء قانون العقوبـات فى المسادة rV9 متضمنا النص فى الفقرة الأولى على جريمة التلوث على النحو التالي - 1" :كل من يسبب التلوث الضوضائي بدرجة غير مقبولة من خلال استخدام الأجهزة التقنية أو المنشآت، أومن الآلات أو المركبات

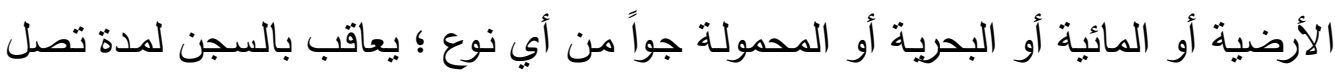

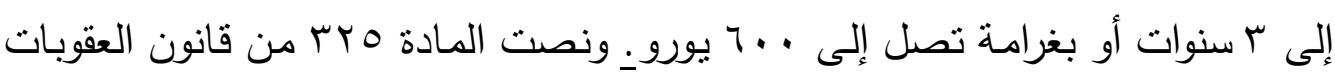

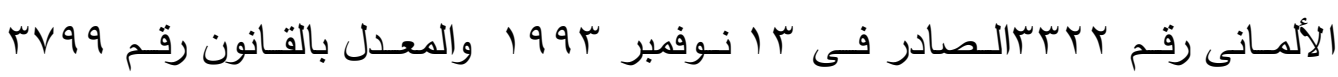

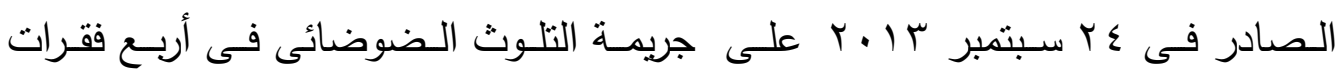
جاءت الفقرة الثانية على النحوالتالى:

· (2) أي شخص، أثناء تشغيل منشأة، ولا سيما مصنع أو آلة، متسبيا فى انتهاك للواجبات المنصوص عليها في القانون الإداري والتي تعمل على الحماية من الضوضاء

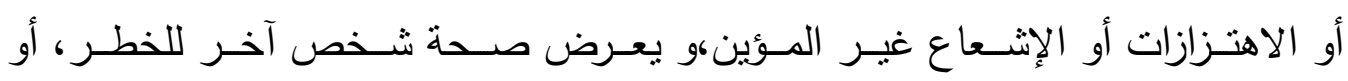
الحيوانات التى ليست ملكهه أو الممتلكات ذات القيمة الكبيرة التي يملكها شخص آخر يعاقب بالسجن لمدة لا نزيد عن خمس سنوات أو غرامـة مالية. فالسلوك الإيجابى في

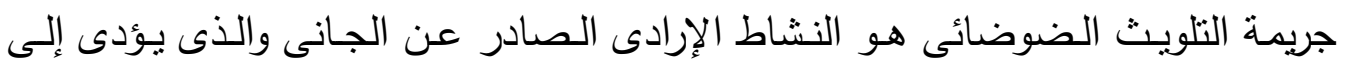
تغير في مواصفات الهواء الطبيعى من جراء إحداث أى أصوات أو اهتزازات أو ذبذبات

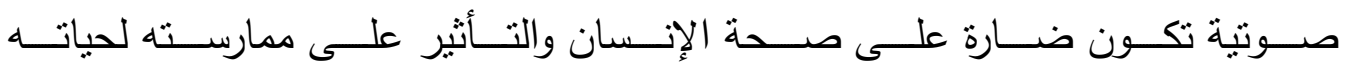
الطبيعية( (ه) ويعتبر ارتكاب جرائم التلوث الضوضائى بسلوك إيجابى السمة الغالبة من

(. (0) د. أحمد حامد البدرى الحماية القانونية للبيئة فى المملكة العربية السعودية معهد الأدارة مركز

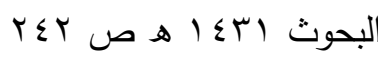
(10) هذا التعريف خلبط من التعريف القانونى لـ " تلوث الهواء" بحسبان أن هذا الأخير يعنى " كل

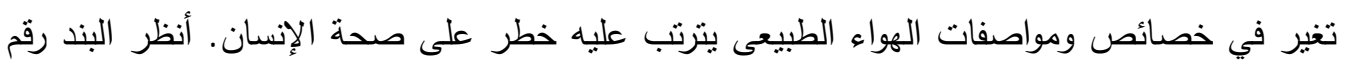

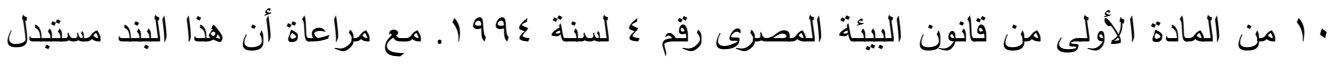

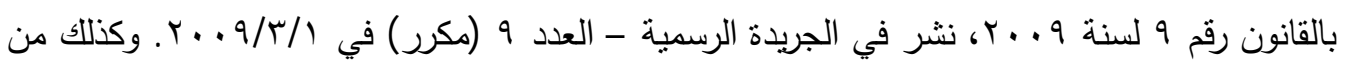


واقع النصوص ذات الصلة بتجريم التلوث الضوضائى المنصوص عليها فى غالبيـة القوانين، حيث أن الغالبية العظمى من هذه الجرائم تتحقق بأفعال إيجابية، شأنها في ذلك

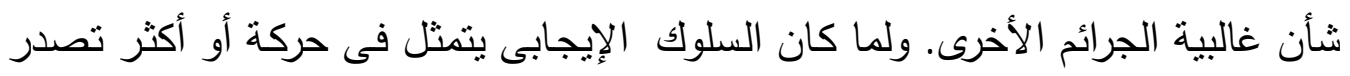
عن عضو أو أكثر من أعضاء الجسم، ويكون من شـأنها أن تحدث تغييرا فيى العالم

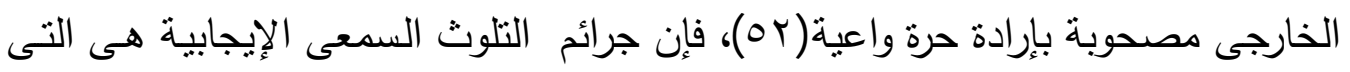

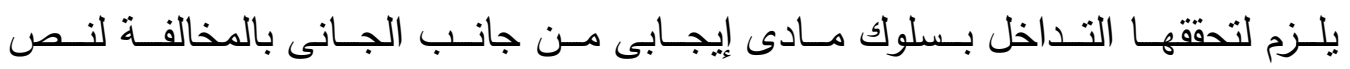

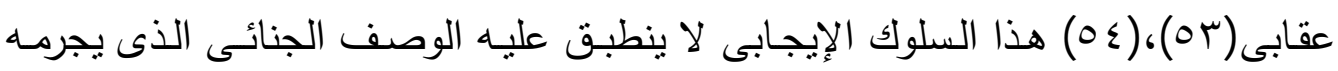

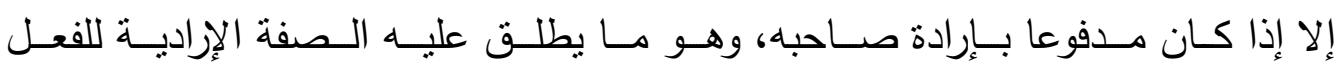
(00) Voluntarines of conduct

التعريف الوارد بالقانون الاتحادى بدولة الإمارات العربية رقم •؟؟ لسنة 1999 في شأن حماية البيئة

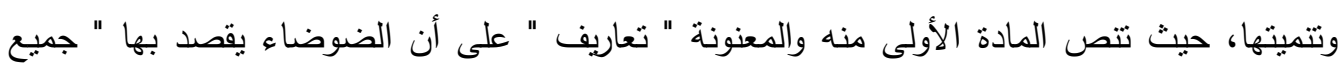

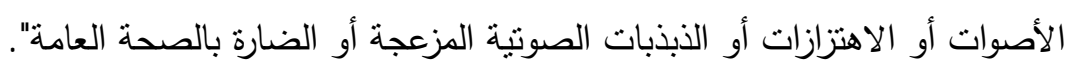

(or) J. W. Cecil turner: Kenny,s outlines of criminal law Sixteenth Edition 1952, Cambridge university Press.P. 23. Smith and Hogan on criminal law op., Cit. P. 35p Michael J. Allen: Cases and materials on criminal law seventh editions London 1997. P. 22.

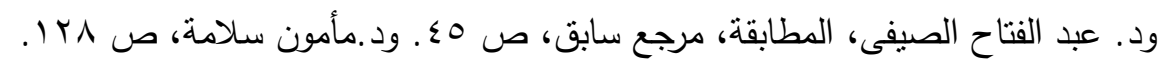

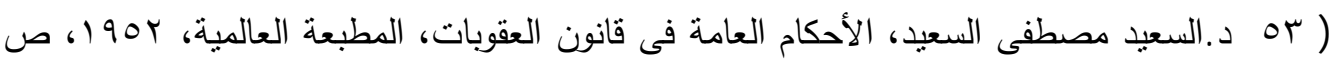

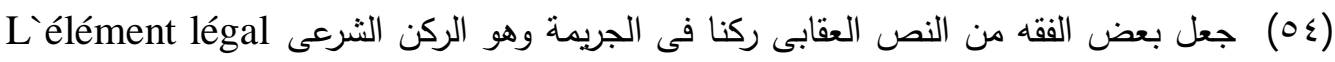

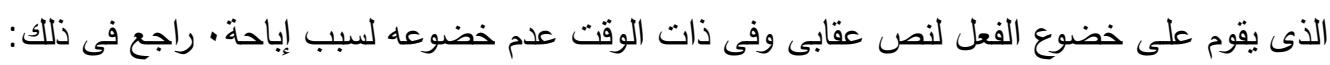

Levasseur (A.) chavanne (A.) Montreuil (B.) et Bouloc (B.) droit pénal général et procedure pénale 13 edition sirey 1999. P. 34. (le principe de la légalité des délits et des péines) ; Garraud (R.), T. I No. 137 P. 292 (Nul delit unlle peine sans une loi) .

وراجع أيضا الدكتور / محمد زكى عامر : القسم العام، دار الجامعة الجديدة للنشر ، الإسكندرية،

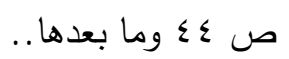

๑0) Catherine elliott and Frances quinn; criminal law pearson fifth edition 2004. 


\section{السلوك السلبى فى جرائه التلوث السمىى:}

وقد يتخذ السلوك الإجرامى شكل الامتتاع الذى يمثل الشكل السلبى للسلوك

الإنسانى، وإذا كان الفعل بمفهومـه الإيجابى هو إتيان حركة عضوية إيجابية فى العالم الخارجى فإن المفهوم الطبيعى للامتتاع الذى يقابله هو عدم الإتيان بفعل معين يفرضـه إلهـ

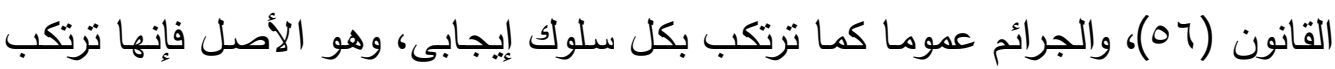
بكل سلوك سلبى عندما يضع القانون التزامـا بعمل ويعاقب فى حالة الامتتاع عن تتفيذ

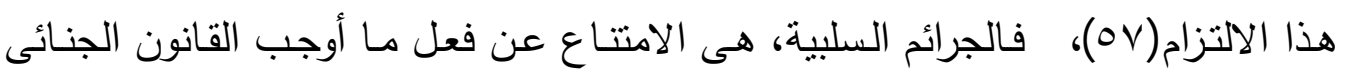

., P. 9; Jonathan herring criminal law. criminal law palgrave Macmillan fourth edition 2005.

., P. 56; Merle (R.) et Vitu (A.), Traité de droit criminel 6 émé éd cujas 1984, No. 454. P. 582.

(7ه راجع مؤلف د. مأمون سلامة بالإيطالية، جرائم الارتكاب بطريق الامتتاع، مشار إليها فى القسم

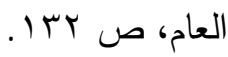

( ov) Il reato commissive mediante

Pradel (J.), droit penal T. I. éd cujas Paris, 1994 No. 365. P. 398; Rassat (M.L.) droit pénal édition 1987, No. 230. P. 332; Vidal (G.) et Magnol (J.) , Op. Cit. No. 79 P. 126; levasseur (G.), =

= Chavanne (A.), montreuil (J.), Bouloc: droit Pénal genéral et procédure Pénale 13 éme éd sirey 1999 No. 73. P. 30; Levasseur stefani (G.) Levasseur (G.) et Bouloc (B.), droit Pénal éd, 15 éme éd 1995 Dalloz No. 215, P. 184. Pradel (J.), droit Pénal comparé éd Dalloz 1995 No. 160 P. 234; Garraud (R.), op. Cit., No. 112 P. 242.

$$
\text { وفى الققه الإنجليزى: }
$$

Smith and Hogan on criminal law Fifth edition Butterworth 1983 P. 43; and Eleventh edition 2005. P. 75; Catherine elliott and Frances quinn Op. Cit., P. 10' Andrew Ashworth, Principles of criminal law Oxford university press fourth edition 2003 ., P. 110' Willam Wilson. Op. Cit., P. 77; Michael Jefferson: Criminal Law longman group 1992 P. 88 and P. 89; Micheal J. Allen: Cases and materials on criminal law fourth edition London 1997 P. 26; Micheal t molan: Graeme Broadbent: Cases. Materials on criminal law, pitman publishend London Malon and G Broadbent 1994 P. 5; Janet Dine and James Gobert, Cases and Materials on cirminal law Oxford University Press, 4 edtion 2003, PP. 85:87. 


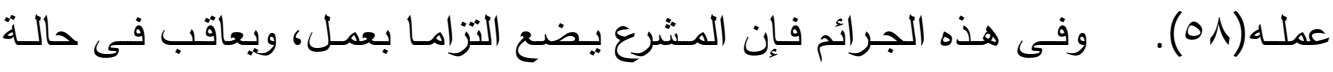
الامتتاع Omisson عن القيام بهذا العمل، وعلى ذللك فإن إحجام الجانى وامتتاعـه لا

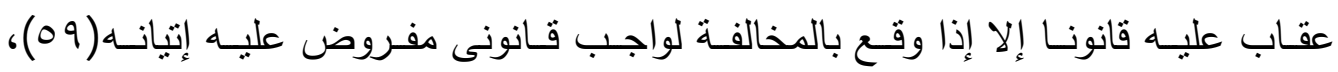

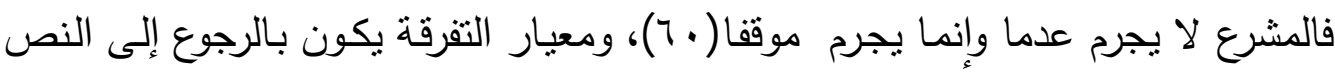
الذى يتضمن الجريمـة ويبين عناصرها الماديـة، فإذا كان النص ينهى عن ارتكاب فعل

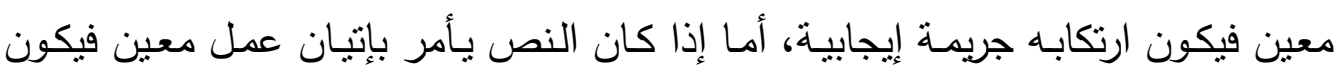

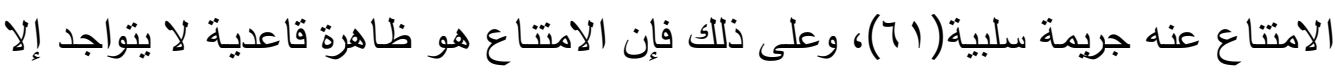

(0^) Larguier (J.), Droit Pénal général, 15 éme éd Dalloz, 1995, P. 22.

د. محمد كامل مرسى: شرح قانون العقوبات، القسم العام، طبعة ثانية، مطبعة الرغائب، القاهرة

(

(०9) Vidal (G.) et Magnol (J.), Op. Cit., No. 79 P. 126 (comme l’obligation de déclarer dans les 3 Jours la Naissance d,un enfant) ; Catherine Elliott and Frances quinn op. Cit., P. 12; William Wilson criminal law Doctrine and theory second edition 2003., P. 85; Alan Reed and peter seago Op. Cit., P. 34; Andrew Ashwarth Op., Cit., P. 111.

د. السعيد مصطفى السعيد: الأحكام العامة، دار النهضة العربية 1910 ، ص بـ بـ؛ ود.

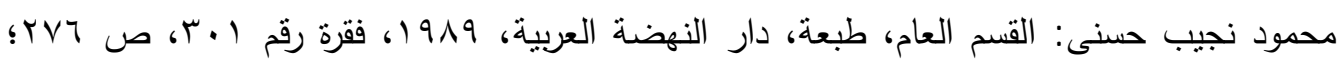

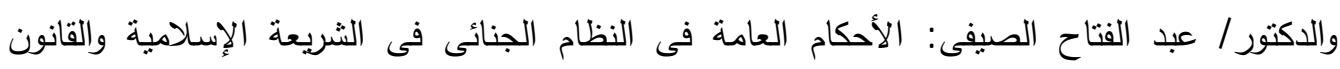

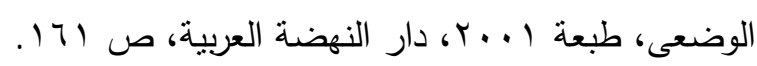
( V $\varepsilon$ ) Acodoppi II reato commissivo propria 1988.

مشار إليه فى د. دبد الفتاح الصيفى: الأحكام العامة للنظام الجنائى، مرجع سابق، رقم

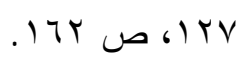

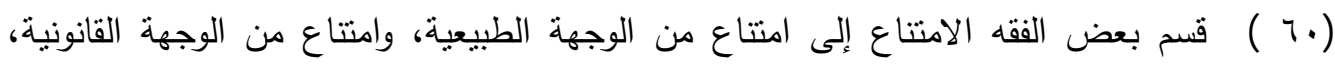

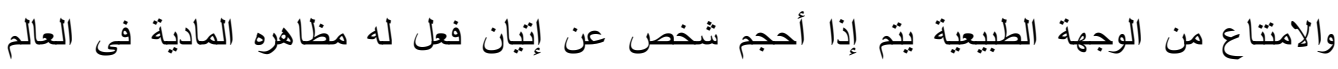

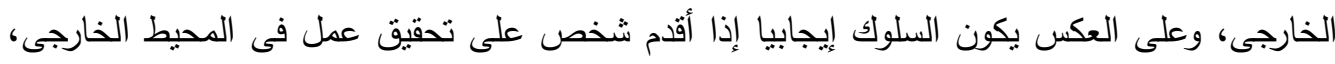

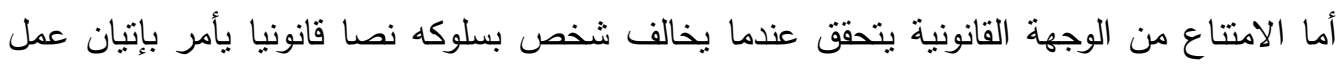

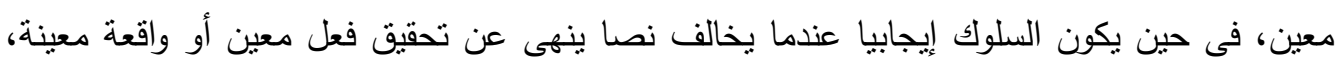

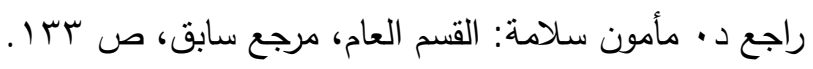




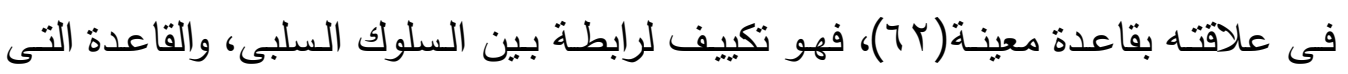
تفرض واجباً على الشخص(سٓ) . فمـن اسـتقراء النصوص العقابيـة المتعلقـة بـالتلوث الضوضائى، نجد أن المشرع حرص على إيراد نصوص تأمر بإنبان أفعال برى المشرع

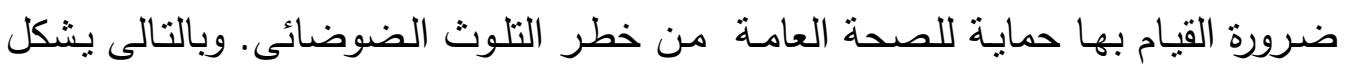

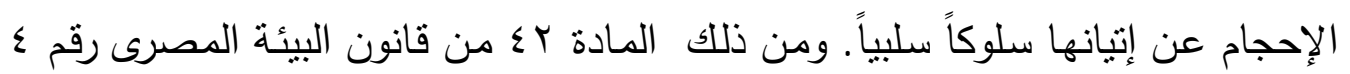

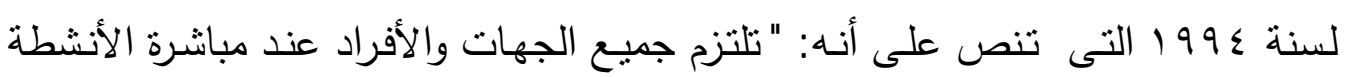

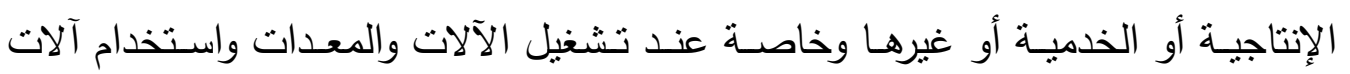

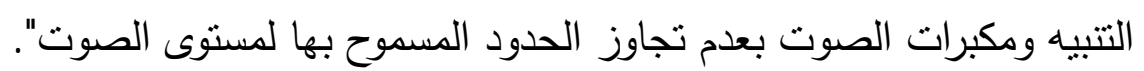
وأضافت الفقرة الثانية من ذات المادة أنه " على الجهات مانحة الترخيص مراعاة أن يكون مجموع الأصوات المنبعثة من المصادر الثنابتة والمتحركة في منطقة واحدة في داني نطاق الحدود المسموح بها. والتأكد من التزام المنشأة باختيار الآلات والمعدات المناسبة لنية لضمان ذلك" ومن مطالعـة الفقرتين السابقتين نجد أن المشرع يأمر الأفراد والجهات الإداريـة المعنية بمنح التراخيص القيام بأفعال و اتخاذ إجراءات وتدابير تعنبر من قبيل التدابير الوقائية.

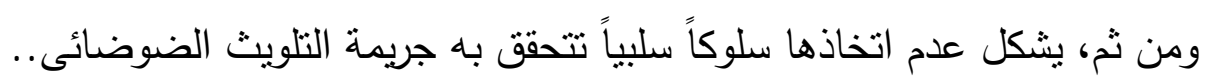
والامتتاع الذى تجرمه هذه القاعدة ليس كل امتتاع بوجه عام بل الامتتاع الذى يضر أو

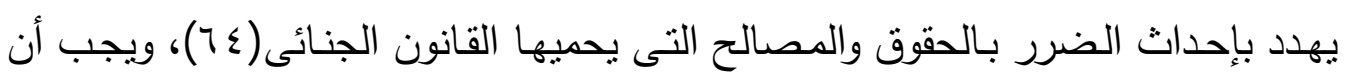
يكون لهذا الامتتاع الصفة الإراديـة أى تتصرف إليهه إرادة الجانى، وهذا الامتتاع البحت يترك أثرا قانونيا، هو المساس بالمصلحة التى يحميها القانون لا تتمثنل فى تغيير فى الإنى

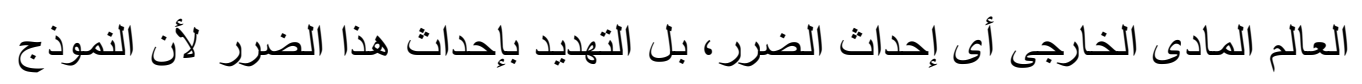

(7) Grispigni, Diritto pénale Vol I Milano 1952. P. 37.

مشار إليه فى د. مأمون سلامة، مرجع سابق، ص ع با. أ.

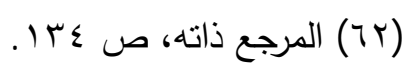

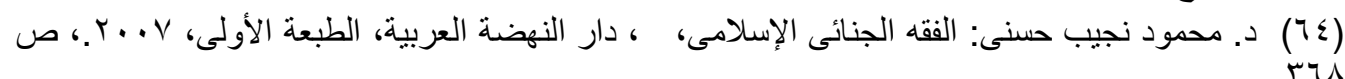


القانونى لجرائم الامتتاع المجرد offenses of pure omission أو الجرائم السلبية البسيطة لا يستلزم حدوث نتيجـة إجراميـة معينـة فيتكون ركنها المـادى مـن الامتتـاع أو لون الإحجام المجرد دون أن تعقبه نتيجة إجرامية معينة(70)، وقد يترتب على الامتتاع نتيجة بالمفهوم المادى كوفاة شخص أو حدوث صمم كلى أو حزئى نتيجة عدم التزام المنشأة الأنة باختيار الألات والمعدات التى تتاسب وعدم حدوث تلوث أنوث ضوضائى.

وأى كان نوع السلوك الإجرامى فى جرائم التلوث السمعى سواء كان إيجابى أو سلبى فهو يتميز بخصائص وسمات معينة من أهمها: أ-أن الـسلوك المكـون لجريمـة التلـوث الـسمعى يـرتبط بـالهواء المحـيط بالإنسسان:

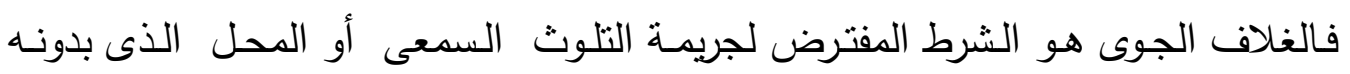
لاتتم الجريمـة.لأن الصوت لاينتقل إلا من خلال الهواء وبالتالى يكون هناك تداخل بين

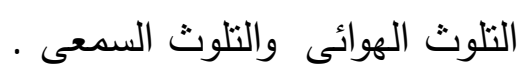
Y- تراخى حدوث النتيجة الإجرامية المنزتبة على السلوك الإجرامى فى الأغلب الأعم:

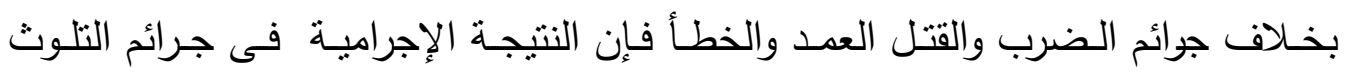
السمعى لاتحدث مباشرة فى أعقاب مباشرة السلوك الإجرامى. فالغالب أن أثنار السلوك جـأن

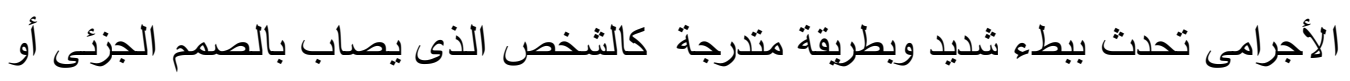

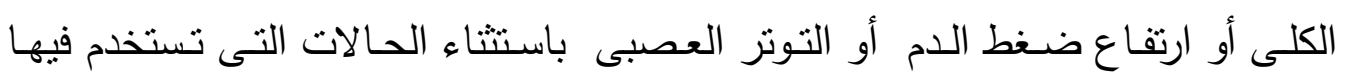

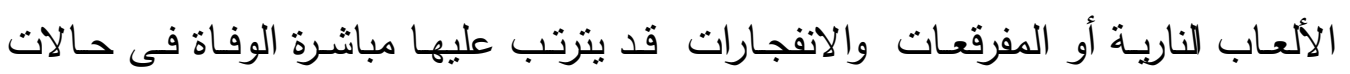
أمراض القلب والضغط المرتفع.

70) Smith and Hogan eleventh edition 2005, P. 76; Janet dine and james gobert; criminal law cases materials on criminal law Oxford University press fourth edition 2003. P 85

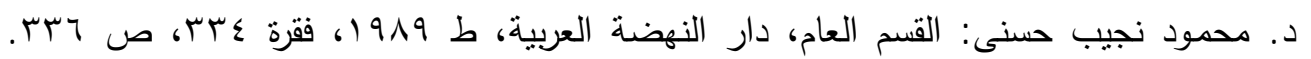

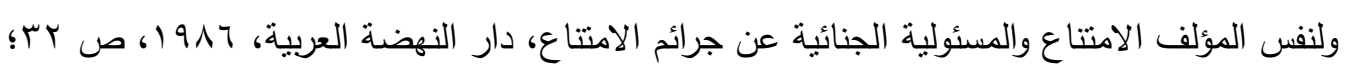

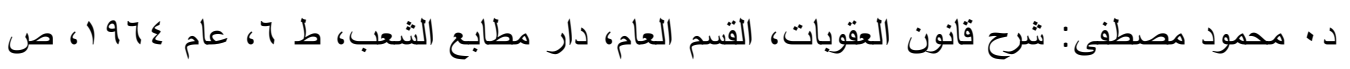

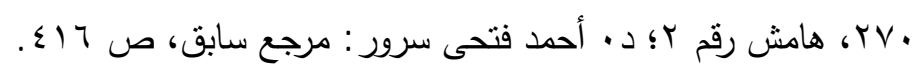


r-السلوك المكون لجريمـة التلوث السمعى ذات حيز محدود : بمعنى أنـه لايمتد خـارج

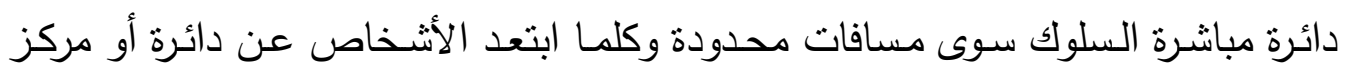
مباشرة السلوك الإجرامى كلما تلاشى الصوت ومن ثم كان الضرر بسيطا وعديم الأثر بخلاف التلوث الهوائى أو البحرى فهو يمتد إلى مسافات بعيدة باعتبار أن الهواء أو

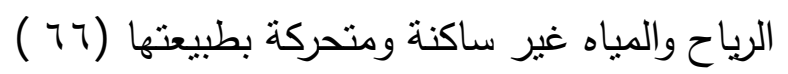

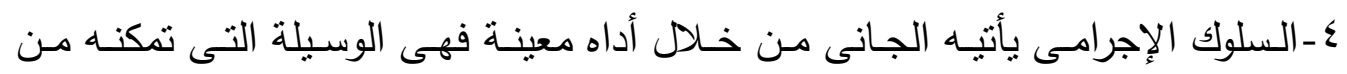

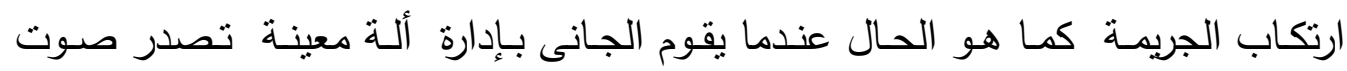
مرتفع أويستخدم مكبرات صوت بل لابد من استعانة الجانى بوسيلة ما لإحداث تلك بألك

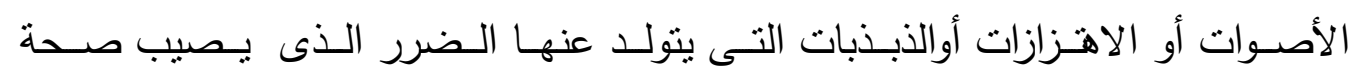

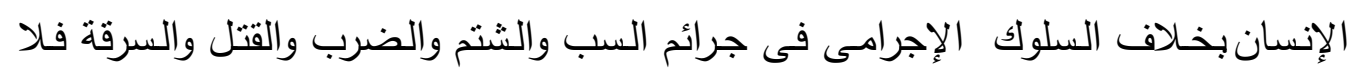
يلزم استخدام أداة أو ألتة لإتمام الجريمـة فيمكن للشخص أن يرتكب القتبل بألة أو باليد

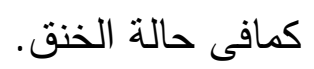

\section{الفرع الثانى}

\section{النتيجة الإجرامية فى جر ائم التلوث السمى}

النتيجة الإجرامية هى العنصر الثانى من عناصر الركن المادى، وهى تتميز وتختلف عن السلوك الإجرامس؛ باعتبارها الأثر الذى يعتد بـه القانون الجنائى فى توقيع العقاب

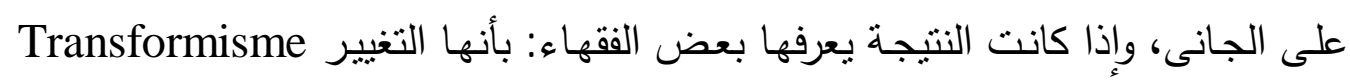

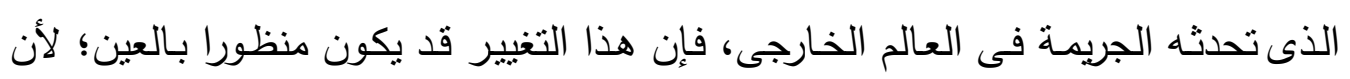

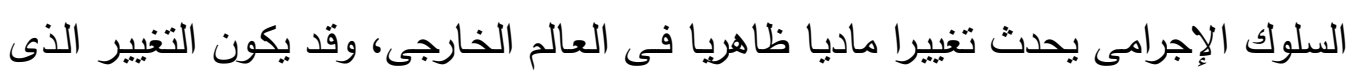

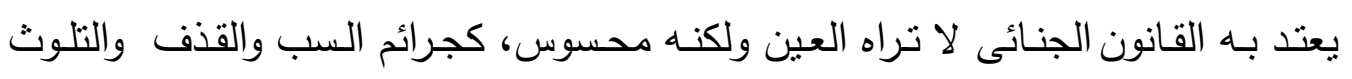
السمعى.وكافة الجرائم التى تتضمن المساس بالشعور العام والراحة والسكينة، فالنتيجة

(77) راجع فى ذلك د ، د. دمن أحمد شحاتة، التلوث الضوضائى وإعاقة التتمية، مكتبة الدار العربية للكتاب بالقاهرة، ... . r. 
الإجرامية فى هذه الجرائم هى المساس بإحساس الناس وشعورهم(TV)، والقانون الجنائى عندما يتدخل بالعقاب على النتيجة الإجرامية لا يقتصر تدخله على الحالات التى يحدث فيها ضرر فعلى كأثز للسلوك الإجرامى وهوالمفهوم المادى للنتيجة ففي جريمة التلوث السمعى يحدث فى العـالم المـادى الخـارجى، تغييـرات: منها مـاهو مـرتبط بالسلوك

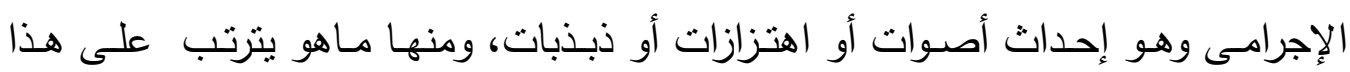

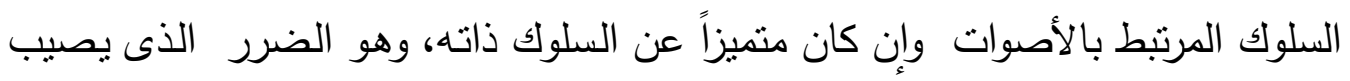

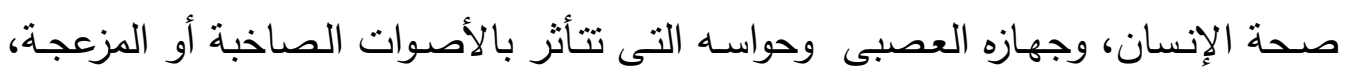

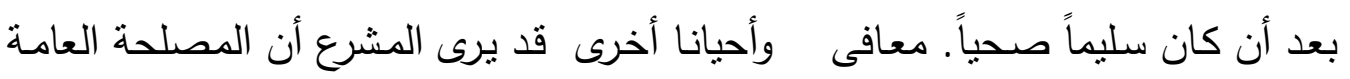
تقتضى التدخل بالعقاب على مجرد تعريض الحق أو المصلحة لخطر حدوث الضرر

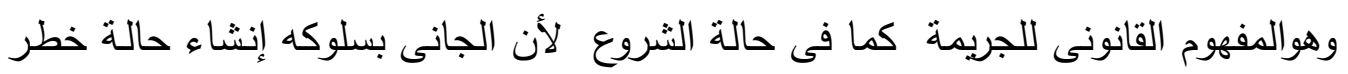
تهدد الحق أو المصلحة بخطر حدوث ضرن كوالنتيجـة المعاقب عليها فـى هذه الجريمـة هـى القلق وتكدير راحـة الأفراد والإزعـاج والتوتز نتيجة الضوضاء التى لايسمح بها القانون ويجرمها باعتبارها تنؤذى السلامة

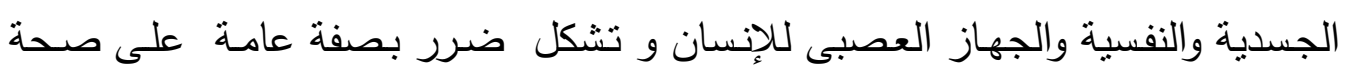
الأشخاص والكائنات الأخرى. فالتلوث الضوضائي يسبب أمراض معينـة للإنسان . فهو يهاجم راحة البال للشخص. ويلعبدورا كبيرا في تسريع التوترات الموجودة بالفعل في تهري

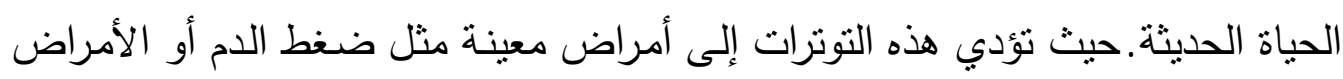

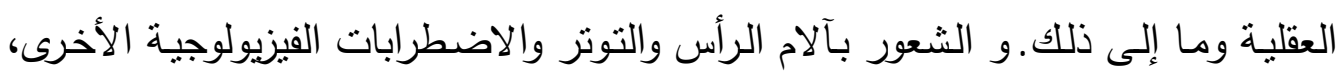

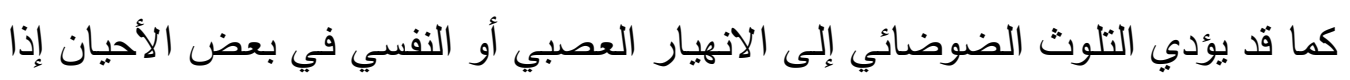

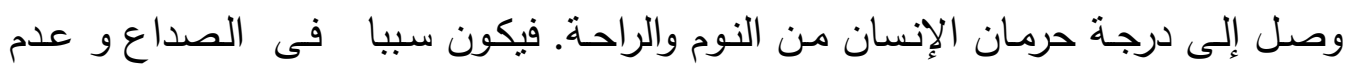

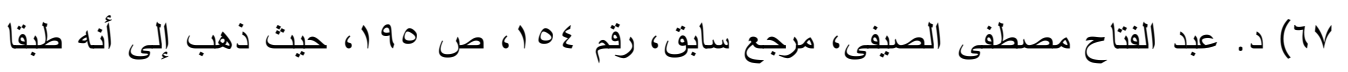

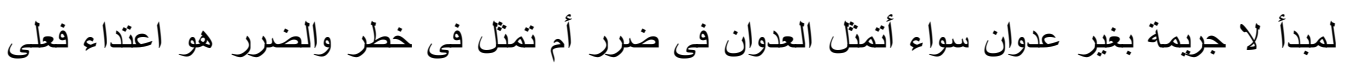

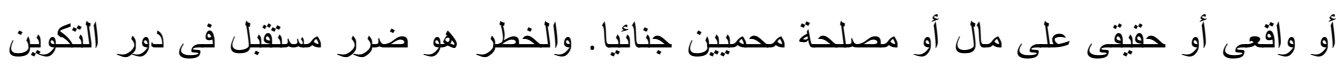

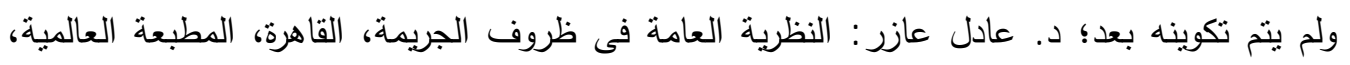

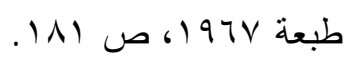


القدرة على التركيز و الثرود الذهني و .ارتفاع ضغط الدم و ارتفاع نسبة السكر في الدم والإفراز الزائد لبعض الغدد ـ والإصـابة بقرحة المعدة والقولـون العصبى و .الشعور

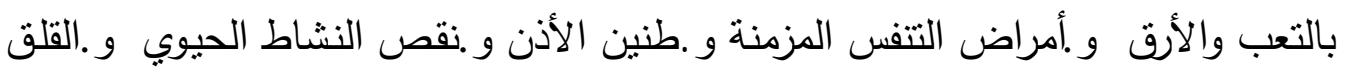

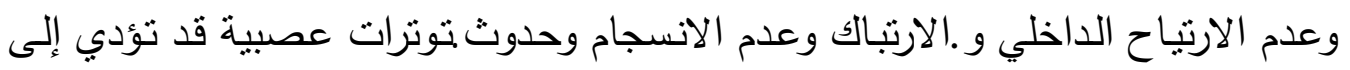

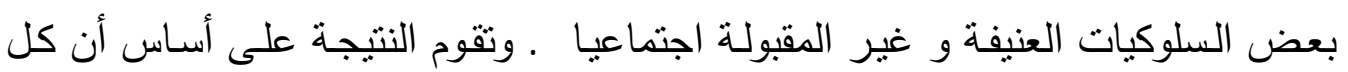

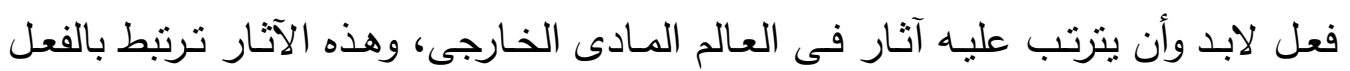

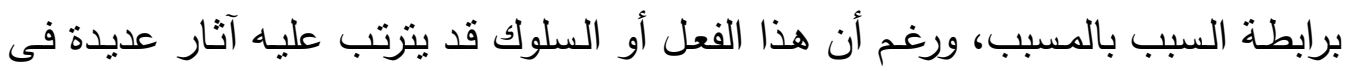
العالم الخارجى، إلا أن المشرع الجنائى ينتقى من هذه الآثار أثرا يعينه ويعتد بـه ويرتب

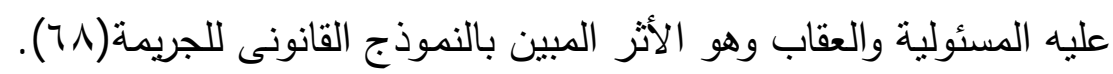

والتغيير الذى يحدث فى العالم الخارجى كأثز لهذا السلوك الإجرامى لا يلزم أن يكون ماديا، كما هو الحال فى جرائم القتل والضرب، أوالصمم الكامل فى جرائم التلوث

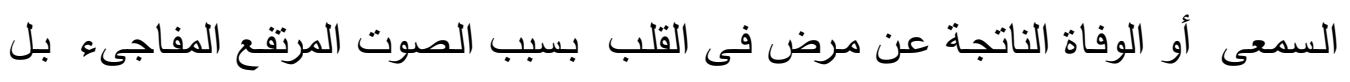

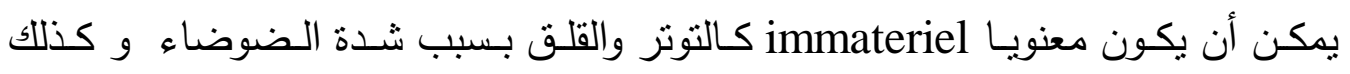
تكدير الراحة والإزعاج والتوتر وعدم النوم بسبب الأصوات الصاخبة كلها نتيجة بالمفهوم

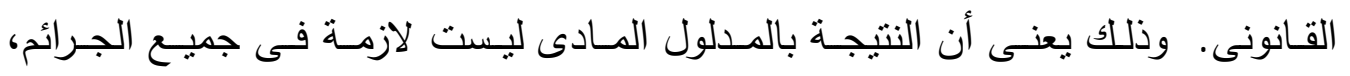

(7^) Pradel (J.), Droit pénal générale T. I, introduction général droit pénal général éd, cujas, 1992, Nol. 342, PP. 366:367.

راجع: د . عبد الأحد جمال الدين ود · جميل عبد الباقى الصغير : المبادئ الرئيسية فى القانون

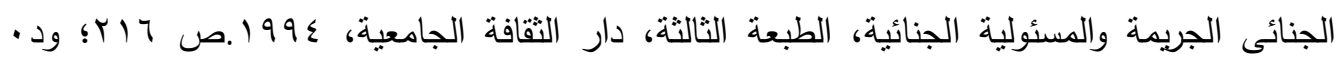

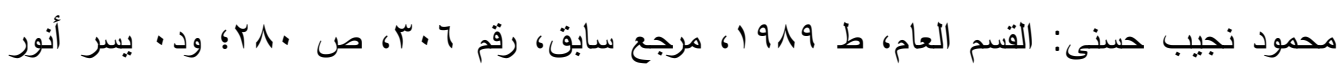

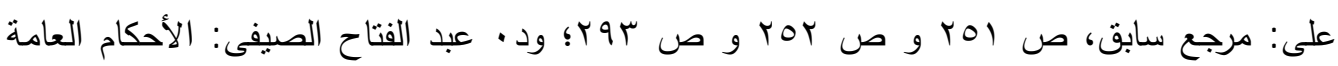

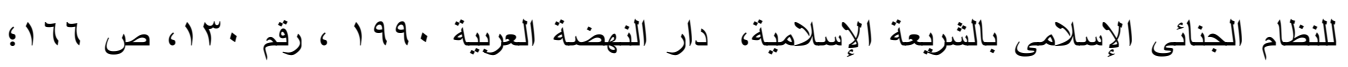

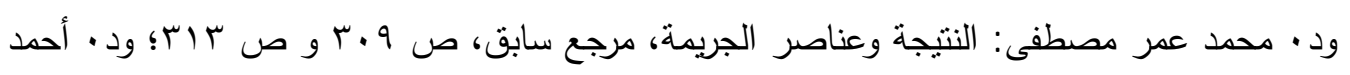

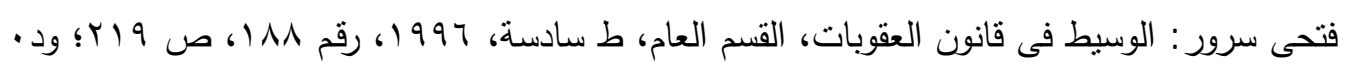

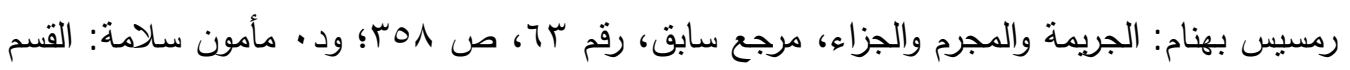

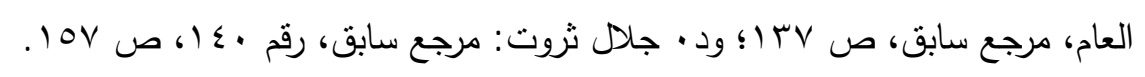


كالجرائم الشكلية(9 7)، وفى المدلول المـادى للنتيجة تستقل النتيجـة عن السلوك والدليل

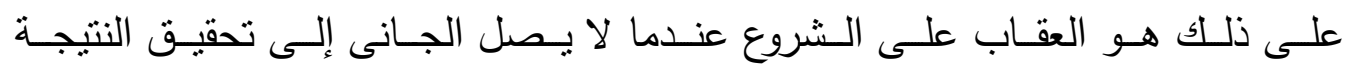

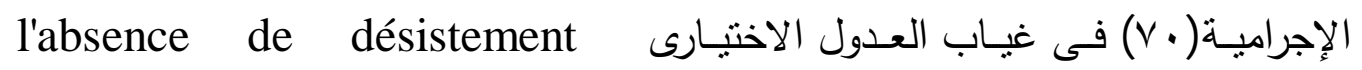
. volontaire

وعلى ذللك يمكن تقسيم جرائم التلوث السمعى طبقا لهذا المدلول إلى جرائم مادية delits materiels وهى التى تكون النتيجة عنصرا لازما فيها كالجرائم التى تؤدى إلى جلى الوفاة بسبب الصوت المرتفع المفاجىء الذى يصيب مريض القلب أوالتوتر و عدم

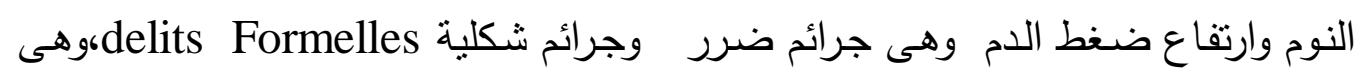
جرائم خطر كامتتاع صاحب سيارة تصدر أصوات مزعجة عن إصـلاحها أو امتتاع مالك كلب عن إطعامـه مما يجعله دائم النباح وإزعاج الجيران ـ ولا يشترط تحقق نتيجة فيها حيث يتم تجريم الفعل أو الامتتاع بصرف النظر عن تحقق أى نتيجة فى العالم المادى الخارجى، فالامتتاع تأبى طبيعته أحيانا على إحداث تغيير فى العالم الخارجى( (V)).

(79) ذهب رأى فى ظل هذا الدفهوم المادى للنتيجة إلى إنكار وجود جرائم تكون النتيجة فيها عبارة

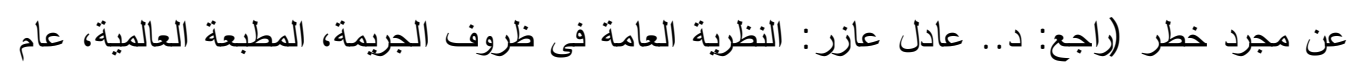

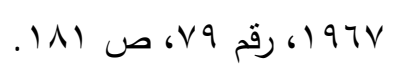

( $\vee$ •) Pradel (J.), Droit pénal général, T. I. général 6 éme éd cujas 1987.

., P. 371; Garraud (R.) , T. I. Op. Cit., No. 236, P. 505; Catherine elliott and Frances quinn; Criminal law Op. Cit., P. 9.

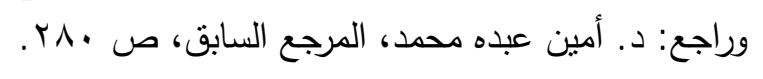

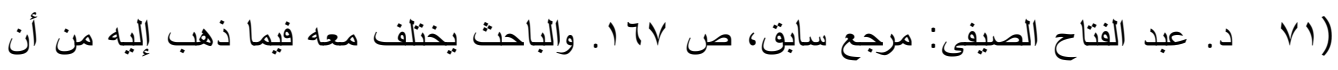

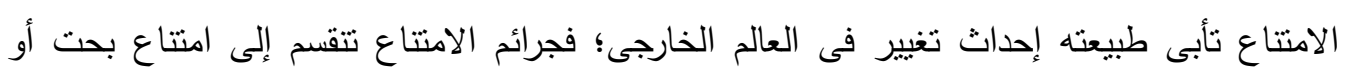

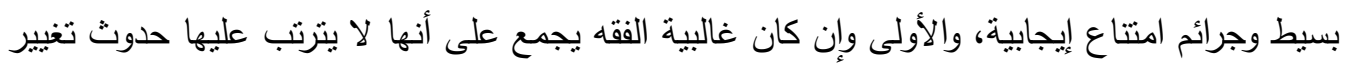

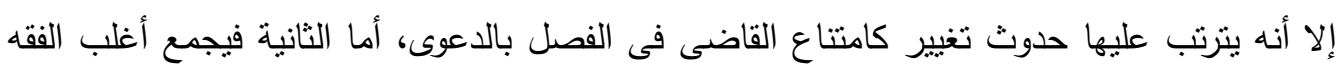

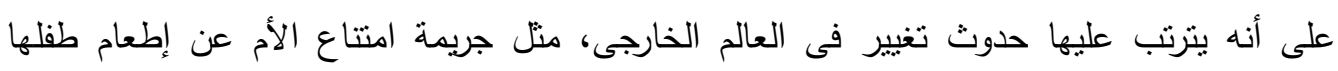

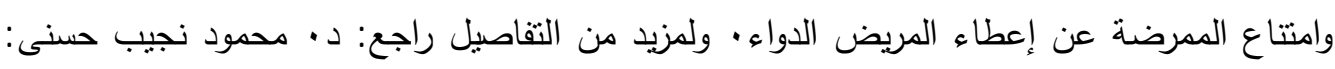

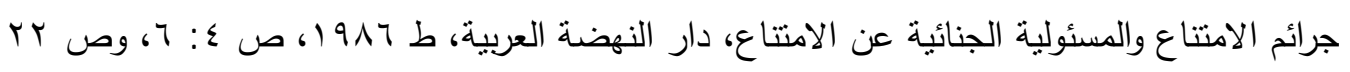
و ص ج ه 
فالمشرع لايتطلب لتوافر جريمة التلوث البيئى، تحقق نتيجة مادية معينة، حيث ينصب

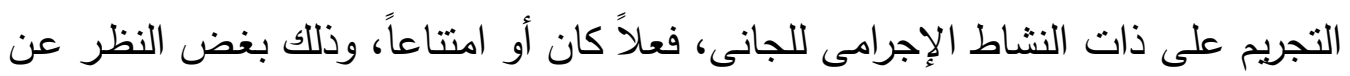
أى نتيجة مستقلة يؤدى إليها هذا النشاط. لـللك فالمسؤلية الجنائيـة تقوم عن جـرائم التلوث البيئى ليس عند تحقق نتيجة مادية معينة فحسب، ولكن أيضاً في حالة السلوك إلى

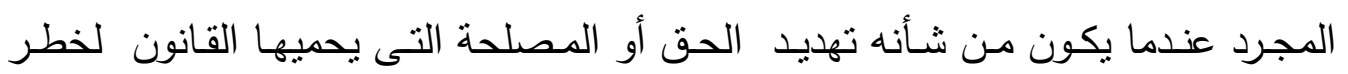

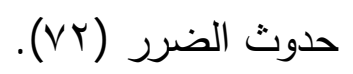

\section{مكان وقوع النتيجة الإجرامية فى جريمة التلوث الضوضائى:}

النتيجة بالفهوم القانونى تحدث فى مكان مباشرة السلوك الإجرامى وهى نشوء حالة خطرة تهدد بحدوث ضـرر فالصوت المرتفع الذى يحدث فى أعقاب السلوك الإجرامى بهدد بحدوث ضرر بصحة المحيطين به.

أما النتيجة بالفهوم المادى فتتقم إلى قسمين: الأول: النتيجة المادية المرتبطة بالسلوك

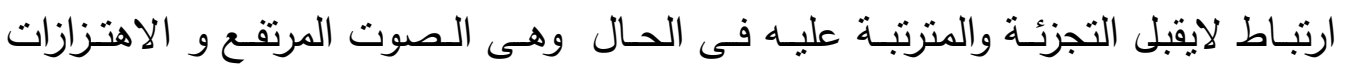

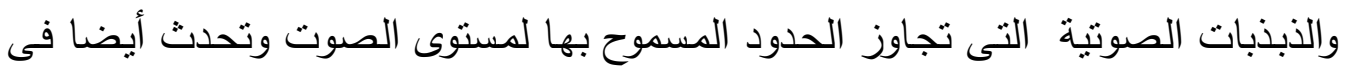
مكان مباشرة السلوك الإجرامى .

أمسا القسم الثانى من النتيجة الماديـة فهى الضرر المرتبط بالسلوك برابطة السبيية وهذه التيجة يمكن أن يتراخى حدوثها كالتوتر والقلق المزمن الذى يؤدى إلى أمراض القلب ومن ثم الوفاة وبالتالى قد تحدث فى مكان أخر غير مكان مباشرة السلوك الإجرامى.

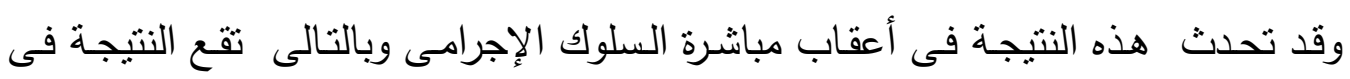

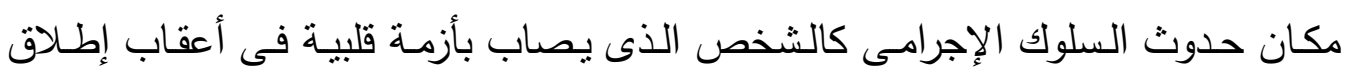
مفرقعات احتفالا بأعياد الميلاد فيتوفى فى الحال فى مكان مباشرة السلوك الإجرامى.

(VY)

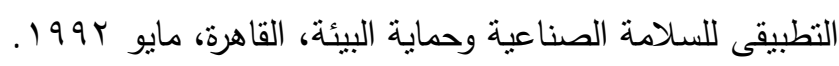


زمـان وقوع النتيجـة الإجراميـة: تقع النتيجـة بـالمفهوم القانونى فى زمن معاصر لزمن مباشرة السلوك الإجرامى أما النتيجة المادية فهى تتكون من شقين الثق الأول المتمثل

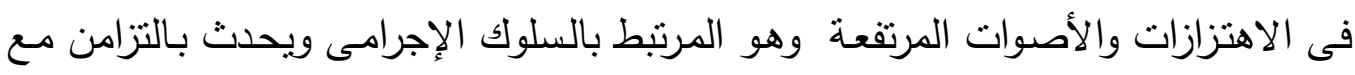
ارتكاب السلوك الإجرامسى أمسا الشق الثانى وهو الضرر المنرتب على السلوك الإجرامسى

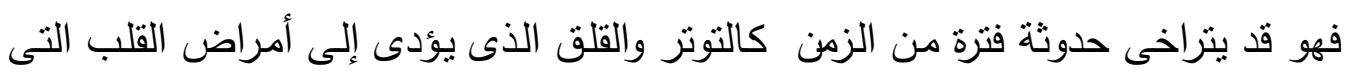

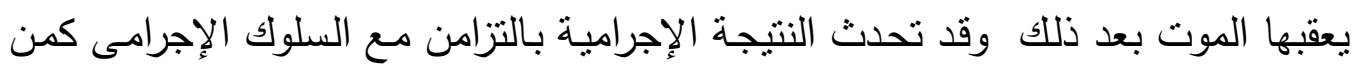

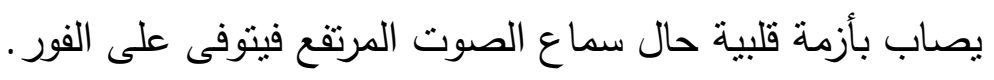

\section{جرائم التلوث السمعى من الجرائم المستمرة}

الجرائم المستمرة infractions continues هى تلك الجرائم التى يقبل النشاط الإجرامى فيها بطبيعته الامتداد الزمنى فترة، قد تطول وقد تقصر ؛ حيث تتزامن وتتلازم إرادة الجانى مع حالة استمرار النشاط الإجرامى، مثل إدارة ألة لمدة يوم كامل أو أيام

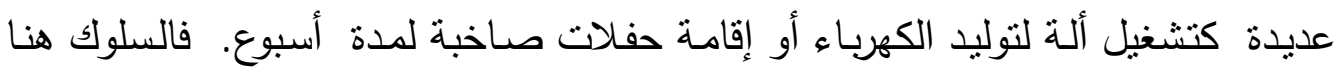
لايختلف عن حيازة المخدرات من حيث الاستمرار (VT)، فالسلوك الإجرامى ممتد فى فئه هذه الجرائم، وفيها تتداخل إرادة الجانى لقيام حالة الاستمرار ، وهذه الجرائم إمـا أن تقع الإسى

Vr) Merle (R.) et Vitu (A.), traite de droit criminal Droit penal spécial par vitu t. 2 éd (cujas) Paris 1982.

., No. 438. P. 562; Stefani (A.), levasseur (G.) et Bouloc (B.), Droit Pénal Op. Cit., No. 218. P. 190; Garçon (E.) . Art I No. 52; 55; Pradel (J.), Droit Penal T I. Op. Cit., No. 366. P. 400; Ayache (A.B.) . .), Dictionnairé de droit pénal général et procédure pénal ellipses edition 2001 P. 92 (infraction dont la réalisation dure un certain temps pendant lequel se manifeste constamment l'intention coupable: exemples: le port illégal de décoration Art 433-14. C. P.

وراجع د. عبد الفتاح الصيفى: الأحكام العامة للنظام الجنائى الإسلامى، مرجع سابق، فقرة

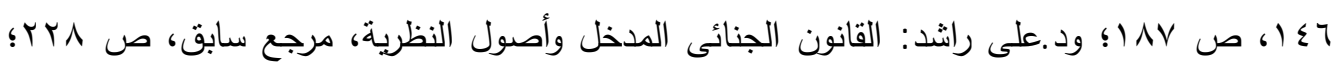

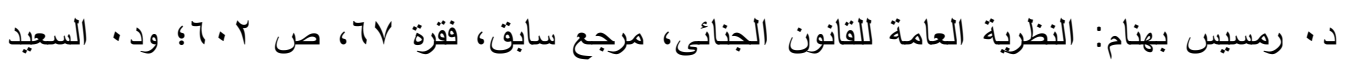

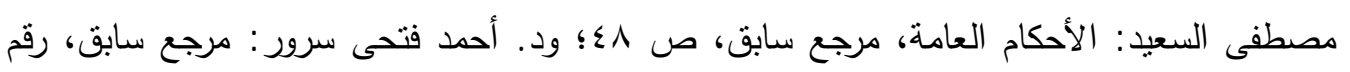

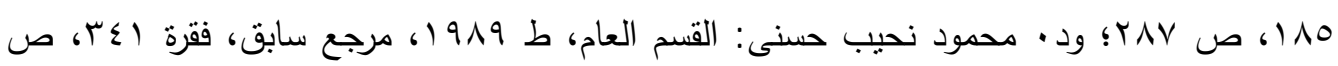


بسلوك إيجابى، كتشغيل ألات موسيقية صـاخبة أو إدارة ورشـة للحدادة فى مكان سكنى دون تصريح. وقد تقع هذه الجرائم بسلوك سلبى بحت كما هو الحال فى نص المادة بع من قانون البيئة المصرى رقم ء لسنة ؟99 99 التى تقول: " تلتزم جميع الجهات والأفراد عند مباشرة الأنشطة الإنتاجية أو الخدمية أو غيرها وخاصة عند تشغيل الآلات والمعدات

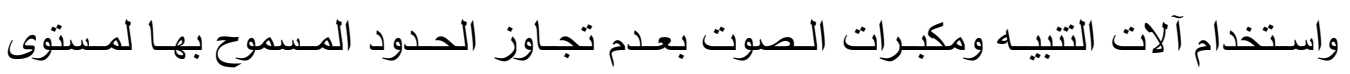

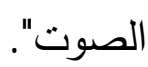

ومعيـار التمييز مـا بـين الجـرائم الوقتيـة والمستمرة هـو النص القـانونى الذـى

يتضمن التجريم، أما الظروف والملابسات التى تحيط بالفعل والوقائع المكونة له فلا دخل فئل لها فى تصنيف الجريمة إلى وقتية ومستمرة(V乏)، والعبرة فى الاستمرار هى بتدخل إرادة

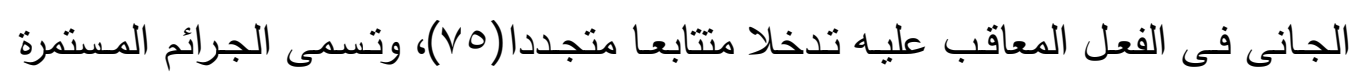
استمرارا متجددا infractions contines succensifs حيث يتوقف الاسـتمرار

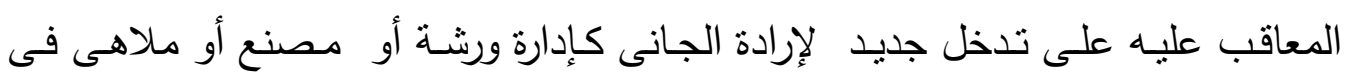
مكان سكنى بـدون ترخيص، وإن بقاء حالـة الاسـتمرار بعـد رفع الدعوى يشكل جريمــة

(V乏) برى د. عبد الفتاح الصيفى أن العبرة بوصف التأقيت أو الاستمرارية هو بالزمن الذى تستغرقه

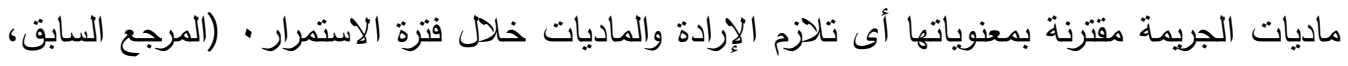

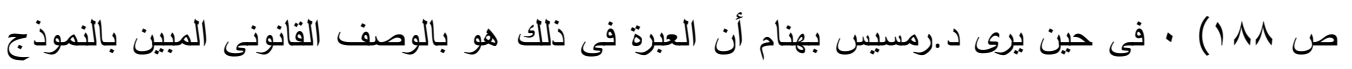

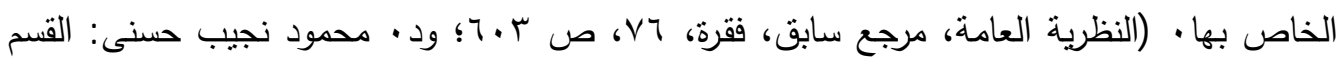

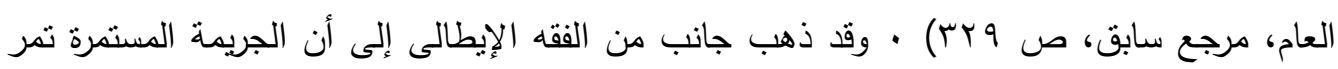

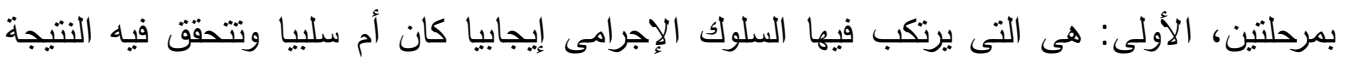

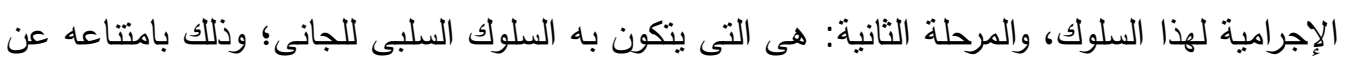

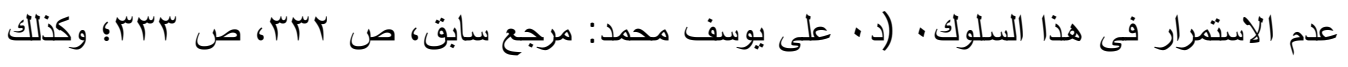

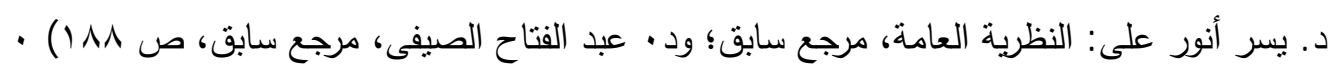

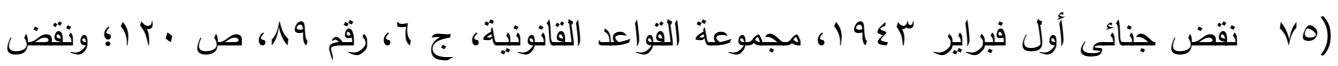

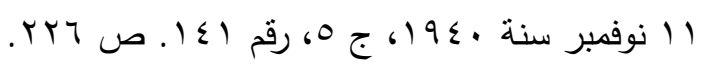


جديدة تستوجب المساءلة الجنائيـة(VT)، باعتبارهـا جريمـة مستمرة أخرى أمـا إذا استمر الركن المادى دون الركن المعنوى فإن الجريمة تخرج عن المعنى الفنى للجريمة المستمرة؛ لذلك يميز الفقه بين نوعين من الاستمرار :

الأول:وهو الاستمرار المتجدد: الذى يلزم فيه الإبقاء على حالة الاستمرار عند

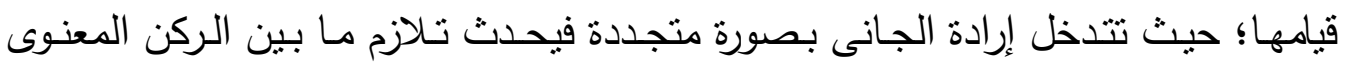

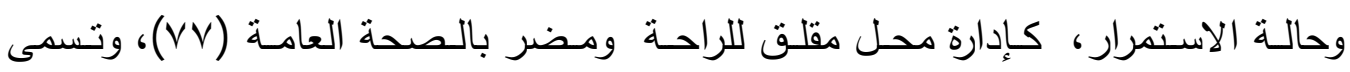
الجريمة عندئذ délit continusuccesif.

والثانى :الاستمرار الثابت الذى تكون الجريمـة فيه فى حالة استمرار ثابتة دون

حاجة إلى تدخل جديد من جانب الجانى، فـلا يحدث تـلازم أو معاصـرة زمنيـة مـا بين

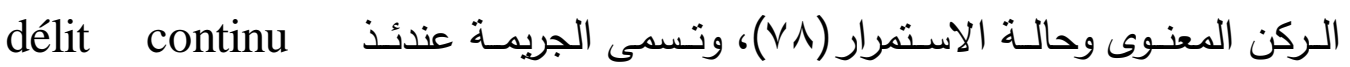

v ) Voir levasseur (G.) et chavanne (A.) montreuil (J.) et Bouloc. B.) : Droit pénal général et procédure pénal 13 éme éd Dalloz 1999. P. 31; Si après une première condamnation définitive, l'infraction continue se poursuit, une seconde condamnation peut être pronocèe. Bien qu'il s'agisse d'une seule entreprise criminelle, puisque la volonté coupable persiste même sans nouvel acte matériel (Crim. 29 Décembre 1952, Gaz. Pal. 1953, I, somm. P. 3) .' Garçon (E.), art I No. 50.

$$
\text { ( VV) }
$$

Garraud (R.), Op. Cit., I. No. 116' Voir aussi levasseur (G.) Chavanne (A.) montreuil (J.) et Bouloc (B.) ; Op. Cit. P. 30; Les infractions cintinues (que l'on appelle encore successives) sont celles qui se prolongent dans le temps par une réitéraition constante de la volonté du coupable après l'abandon de famille, du port illégal de décoration. Qui exige une nouvelle intention coupable a chaque nouvene sortie du délinquant du recel de choses volées qui exige que le receleur conserve volontairement la chose reçue en connaissant sa provenance frauduleuse de la séquestration arbitraire (Crim 8 Novembre 1979. D. 1980 chron 102) .

وانظر فى هذه التقرقة حكم لمحكمة النقض المصرية فى V مايو ابT9 (1، قضية رقم 100 10 لسنة

( راجع فى معنى الجريمة المستمرة: ( V^)

Carraud (R.) . Op. Cit., t. I. No. 116. P. 245. 
permanent

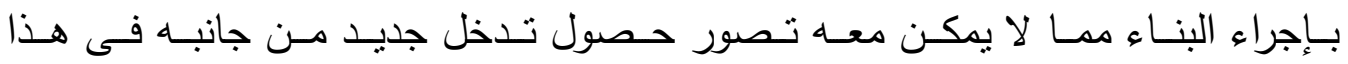
النشاط(Vq)، ومثال ذلك فى جرائم التلوث السمعى جريمة تشغيل أله لتوليد الكهرباء تصدر صـوت مزعج وعالى وتركها تعمل ففى هذه الحالة يحدث التزامن مابين الركن المادى والمعنوى لحظة التشغيل فقط ولاتتدخل إرادة الجانى بعد لحظة التشغيل.

\section{جرائم التلوث السمعى من الجرائم الوقتية}

أغلب الجرائم هى من الجرائم الوقتية التى تقع ويكتمل الركن المادى فيها من فعل ينتج أثره حال وقوعـه أو فى وقت محدود( • ^)، دون التعويل على الآثار الممتدة

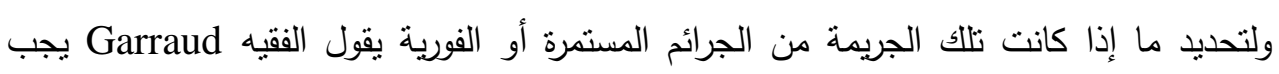
تحليل تعريفها القانونى Analyser Sa définition légale إذ يجب دراست دراسة العناصر المكونة لكل جريمة أو جنحة أوة مخالفة لنعرف إذا كانت جريمة وقتنية أو مستمرة.

C,est donc en étudiant les éléments constitutifs de chaque crime, delit ou contravention que nous determinerons s'il est instantané ou continu. Garraud (R.) . Op. Cit., t. I No. 116. P. 246.

وراجع التقرقة ما بين الجريمة المستمرة والجريمة الوقتية من حيث العقوبة Pénalité والإجراءات

Soit la retroactivité التقادم Soit lo prescription le procédure

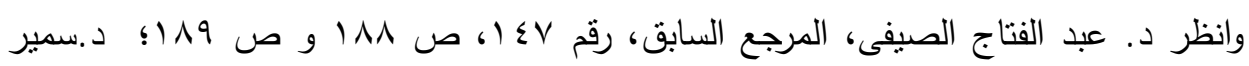

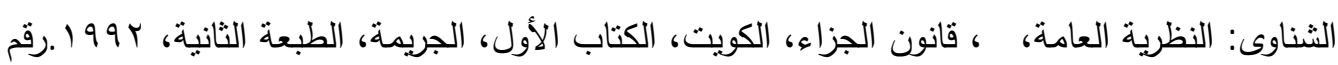

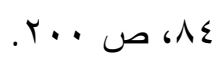

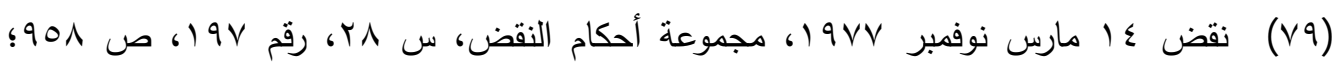

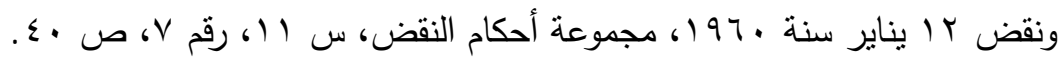

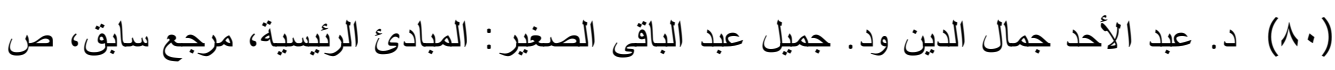
. Y10

Et Voir levasseur (G.) ; Achavanne (A.) Montreuil (J.) et Bouloc (B.) . Op. Cit., P. 30.

L'infraction instantanée est celle qui se réalise en une période de temps pratiquement négligeable: Vol, meurtre, Cela ne veut pas dire qu'une telle infraction n'exige pas parfois une longue préparation; elle se trouve néanmoins consommée en un instant. 
للسلوك الإجرامسى؛ فجريمـة التلـوث الـضوضائى تقـع ت تامـة بمجـرد اسـتخدام مكبـرات الصوت، بصرف النظر عن تراخى حدوث النتيجة المتمثلة فى المرض التام الذى يعجزه

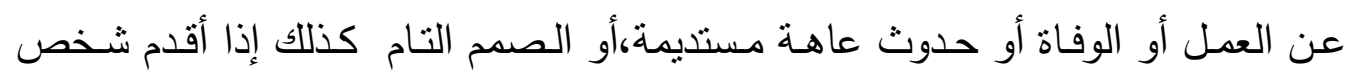

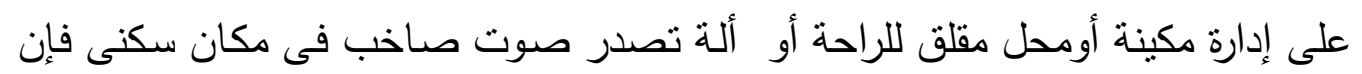

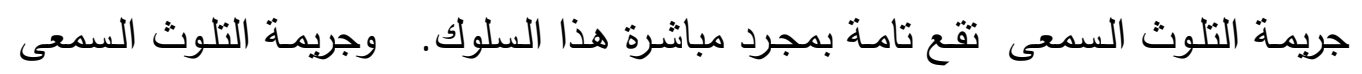
هى جريمة فورية infraction instantane أووقتية وكما تتم بسلوك إيجابى فإنها تتم بسلوك سـلبى( ( ))؛، وقد تتخـذ الجريمـة الفوريـة أو الوقتيـة صـورة يرتكب الجـانى فيهـا جريمته على دفعات تتفيذا لغرض إجرامس واحد وإضـرار بحق قانونى واحد؛ كمن يقوم

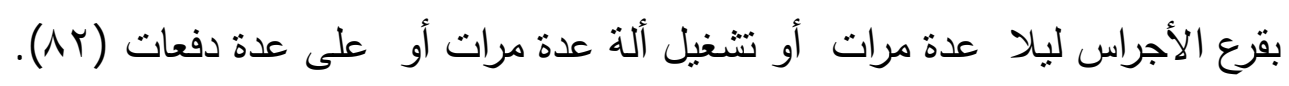
فهذه ليست جريمـة مستمرة، وإنمـا جريمـة وقتيـة منتابعـة، فهى جريمـة واحدة بـالرغم من تكرار الأفعال وتعدد القصد الجنائى لكل فعل؛ وذلك نظرا لوحدة الغرض الإجرامى ووحدة جهان الحق الذى يحميه المشرع(بر).

(^) Stefani (G.), et Levasseur (G.), et Bouloc (B.), Op. Cit., No. 217. P. 189.

ذهب رأى فى الفقه الفرنسى إلى القول بأن الجريمة الوقتية هى التى ينم تتفيذ الركن المادى لها فى

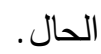

L,infraction instantanée est celle dont l,élément matériel s,exécute en un instant le voil homicide volontaire, voir pradel (J.), Droit pénal général. Op. Cit., No. 333. P. 358, et voir ayache (A.B.) . Op. Cit., P. 94; infraction instantanée est l,infraction qui se réalise en un trait de temps l,infraction instantanée est régie par loi en vigueur au moment des faits et le jour ou elle á été commise constitue le point de départ du delai de prescription de l,action publique. Op. Cit., P. 94; et Voir Garraud (R.) . Op. Cit., t. I. No. 116. P. 245.

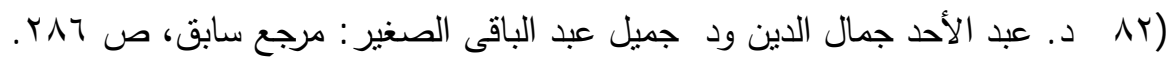

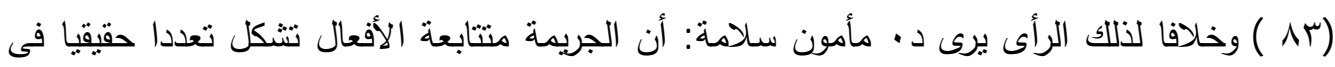

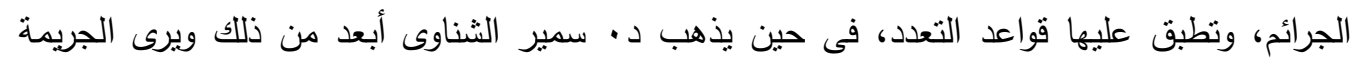

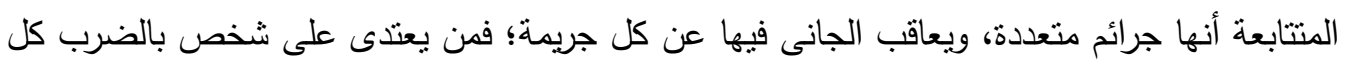


ولقد نص قانون العقوبات الإيطالى على هذه الحالة وعرفتها المادة I/N/ بقولها لا تطبق النصوص السابقة (المتعلقة بنوعى التعدد الحقيقى للجرائم) على من يرتكب ولو

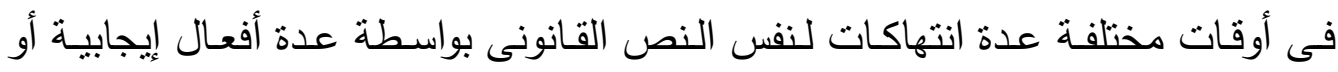
سلبية ناتجة عن غرض إجرامسى واحد، ولو كانت هذه الانتهاكات على درجات متفاوتـة مـن الجسامة، ويطلـق عليهـا infraction successive، والجريمـة منتابعـة الأفعـال عالجها المشرع الإيطالى فى الفقرتين الثانيـة والثالثة مـن المادة إن عقوبات، ومن أهم مقومات تلك الجريمـة وضـوابطها هو ضـابط تجـانس الأفعال المكونـة للسلوك الإجرامسى الإسى

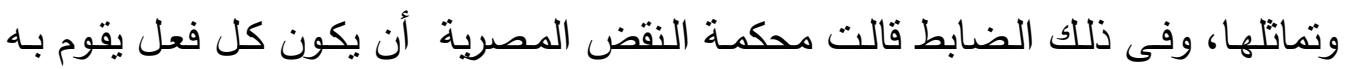

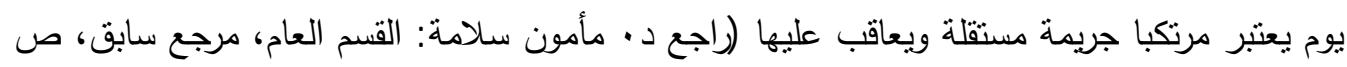

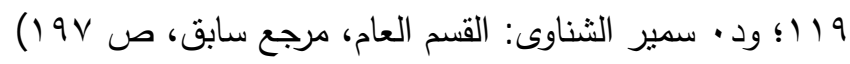

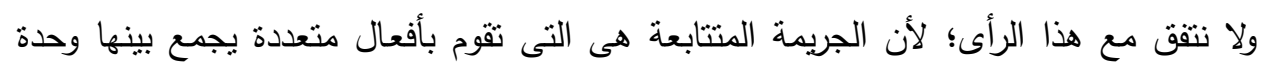

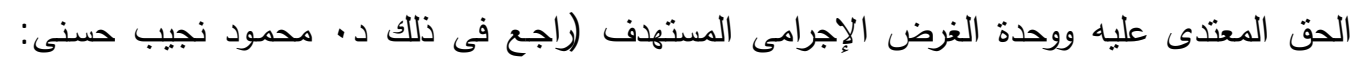

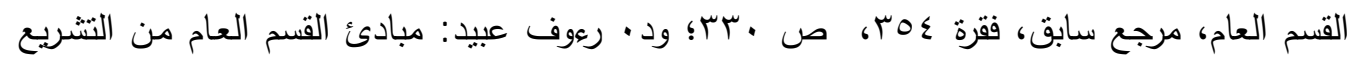

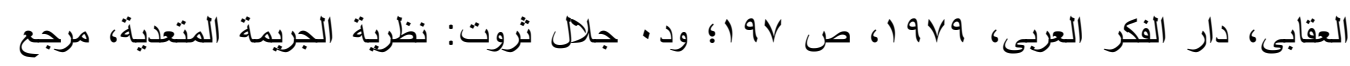
سابق، ص ع 7.

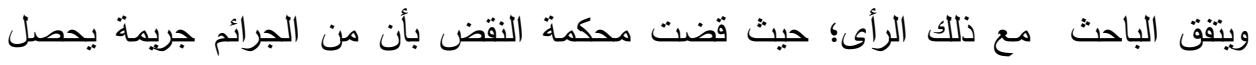

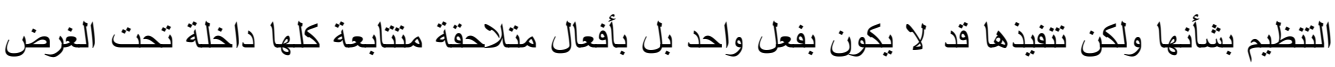

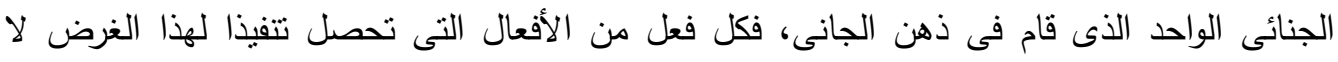

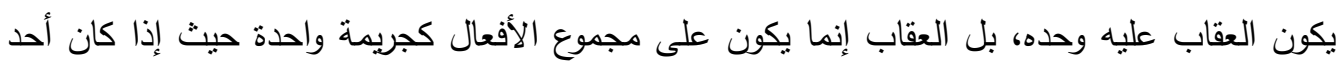

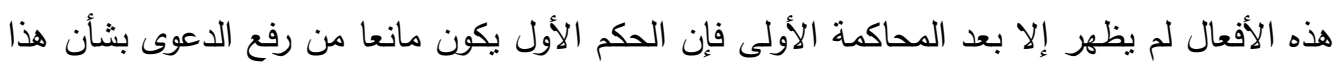

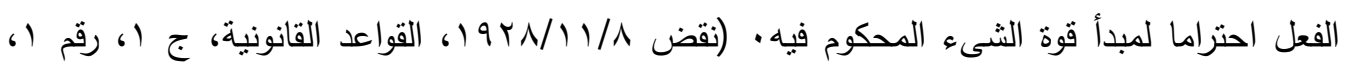

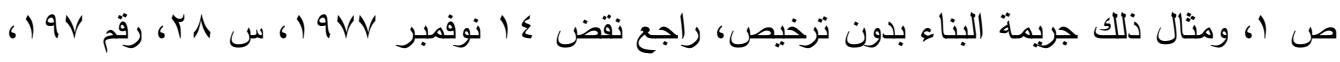

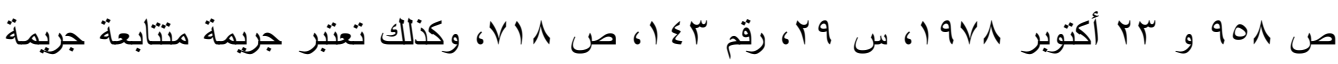
إصدار عدة شيكات فى وقت واحد وعن دين واحد وبدون رصيد وإن تعددت نواريخ استحقاقها • (راجع

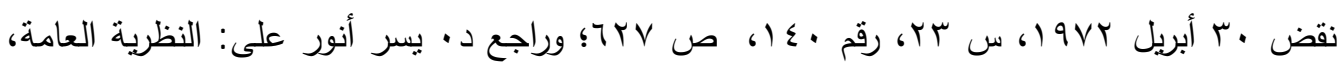

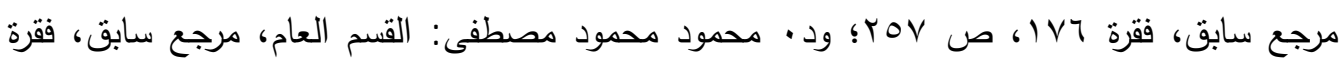

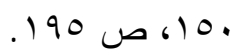




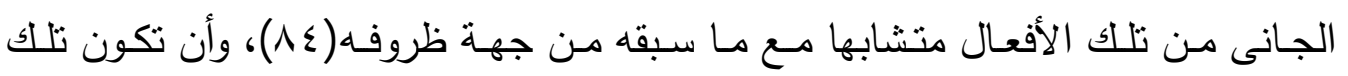
الأفعال ذات هدف واحد أو تقع تتفيذا لغرض إجرامى واحد ،كالشخص الذى يقوم يتشغيل

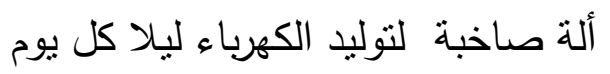

ومعنى ذلك أن تتحد أجزاء وعناصر السلوك الإجرامى فى الغرض، وكذلك فى

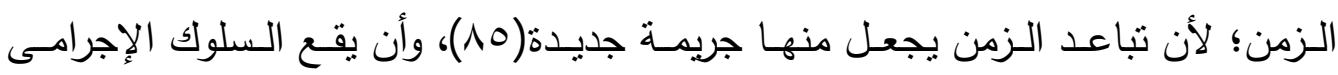

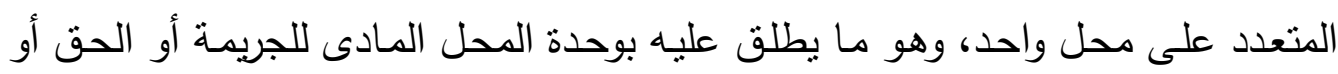
المصلحة التى يحميها القانون الجنائى، كذلك يشترط وحدة المجنى عليه، أى أن يكون أنه المجنى عليه واحدا فى جميع أجزاء السلوك الإجرامى، وهم سكان المنطقة التى يباشر

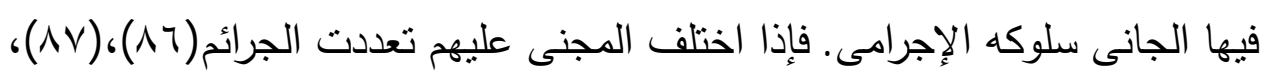

\section{الفرعالثالث}

\section{علاقة السببية}

علاقة السبيية بين النتيجة الإجرامية والسلوك الإجرامى هى همزة الوصل بينهما، وهى التى تجعل من الركن المـادى كيانا قانونيا واحدا، وبدونها لا يمكن إسـناد النتيجـة الإجرامية إلى سلوك الجانى السلبى أو الإيجابى؛ وبالتالى تتعقد مسئوليته وتظهر أهمية

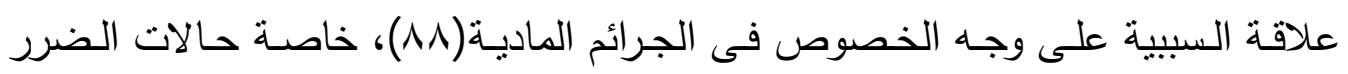

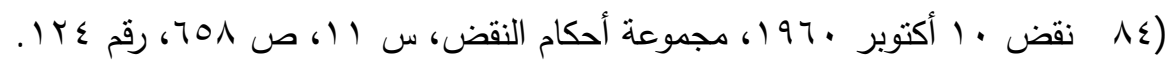

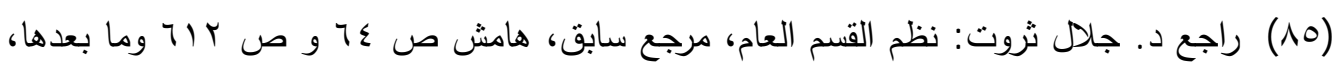

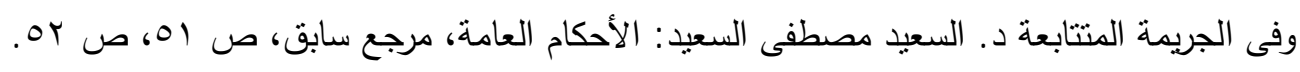

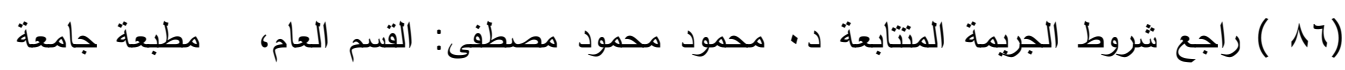

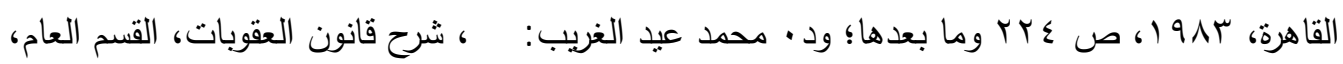

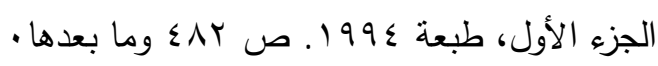

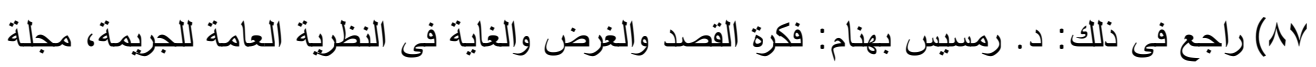

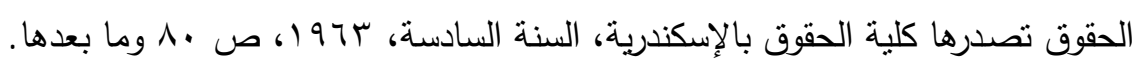
(^^) Merle (R.) et Vitu (A.) : Traité de droit criminal, Op. Cit., (1973) No 490 P.549; et Voir la role de la relation de causalité dans la responsabilité pénale 
كالوفـاة والمـرض والـصرع والإنهيـار العـصبى والتـوتر الناثـى؟ عـن شـدة التلـوث الضوضائى، وهى من أكثر الجرائم إثارة لمشكلة السبيية، لا سيما فى مجال بحثنا التى قد

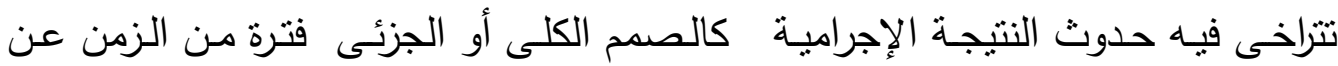

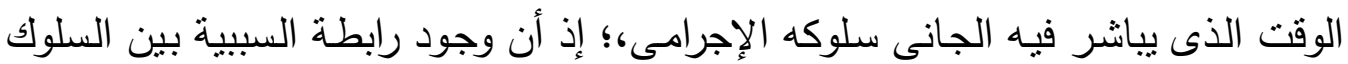
الإجرامى والنتيجة الإجرامية هو شرط أساسى؛ لكى يكون الجانى محلا للمساءلة الجنائية والمدنية، وهو الذى يعطى النتيجة معناها القانونى فى نظر التشريع العقابى، فالمسئولية

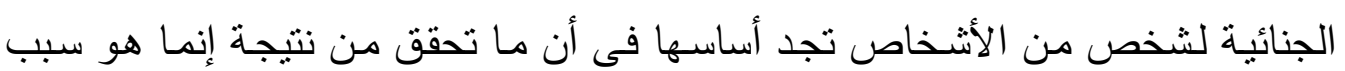

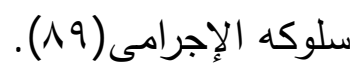

chez merle (R.) et Vitu (A.) . Op. Cit, édition 1978 No.534 P.680; et Voir Garraud (R.) Op. Cit., t. I. No. 297. P. 587.

$$
\text { وفى الفقه الإنجليزى: }
$$

L. B. Gurzon, Criminal Law, seventh Edition, 1994 No. 10 P. 26 and 27; Michael T Malon and Graeme Broad bent, criminal Law, Cases and Materials on criminal Law, 1994 P. 10; Michael Jefferson, Criminal Law, longman group, 1992 P. 32. And 33; Smith and Hogan, on criminal, law Op. Cit., P. 276; William Wilson; Criminal law Doctrine and theory second edition 2003. P. 95; Raymond youngs; English, French. German; comparative law edition 1998 P. 299; Alan Reed peter seago criminal law; sweet maxwell edition 1999 P. 40 Janet Dine and James Gobert; Cases and materials on criminal law 4 th edition 2003. P. 110; Andrew Ashwarth; Principles of criminal law Oxford University press 4 éd 2003 P. 124; Catherine elliott and Frances; Op. Cit,. P. 82; Russell Heaton; Criminal law oxford university press second edition 2006, P. 30; Marianne Giles; criminal law. Op. Cit,. PP. 2 :3.

وفى الفقه المصرى المراجع المتخصصة: د. · محمود نجيب حسنى: السببية فى قانون العقوبات مرجع سابق؛ ود · رؤوف عبيد : السبيية الجنائية بين الفقه والقضاء دراسة تحليلية مقارنة،

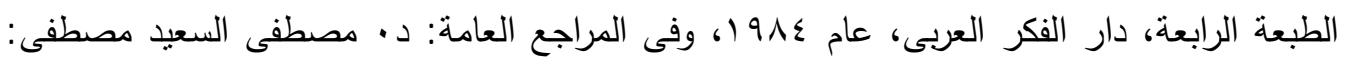

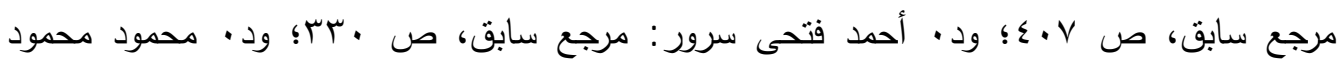

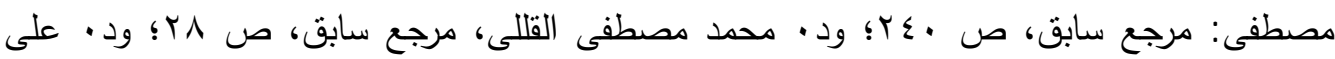
راثد: القانون الجنائى: مرجع سابق، ص ابr؟؛ ود محمود نجيب حسنى: القسم العام، مرجع سابق،

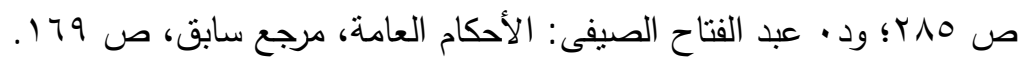
(^^) د .عبد الأحد جمال الدين ود · جميل عبد الباقى : المبادئ الرئيسية للقانون الجنائى، مرجع سابق، 
وعلاقة السببية عنصر فى الركن المادى للجرائم العدديـة والجرائم غير العمديـة، ولا علاقة لها بـالركن المعنوى فى الجريمـة( • 9)، ويثار البحث بخصوصها في الجرائم ذات النتيجة، والتى تسمى بالجرائم المادية التى تحدث تغييرا فى العالم الخارجى، ولا تثور هذه المشكلة بصدد الجرائم الثكلية أو جرائم السلوك البحت، كجرائم اللغلط أو الضجيج فى الليل حيث لا يتطلب القانون حدوث نتيجة مادية حتى يمكن البحث فى العلاقة التى تربط ما بين السلوك الإجرامى وتللك النتيجة( (9)؛ كجريمة استعمال مكبرات الصوت ليلا

(9.) Merle (R.) et Vitu (A.) . Op. Cit., No. 536. P. 683. La Faute pénale envisagée comme condition "Sine qua Non" du résultat See the connection between fault and result in smith and hogan. Op. Cit., edition 2005. P. 54; Michael Jefferson, Op. Cit., P. 31.

خلافا لذلك يرى د. محمد محيى الدين عوض أنه من الخطأ المضلل أن نعالج السبيية الجنائية

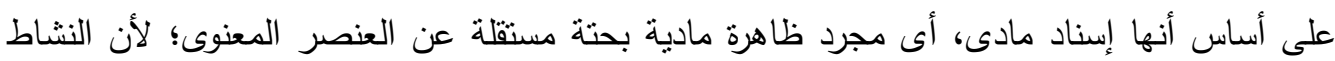
الإجرامى يتكون من عنصرين، أحدها: عقلى والآخر مادى. (بحث منشور فى مجلة القانون

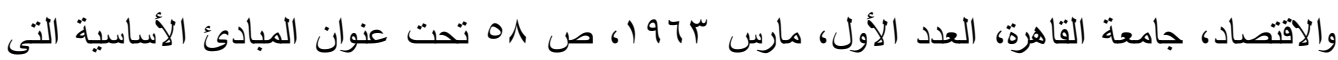

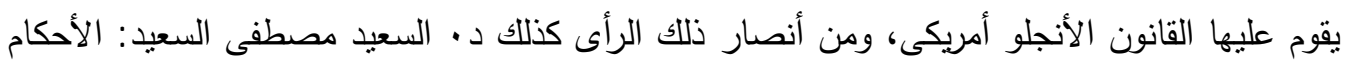

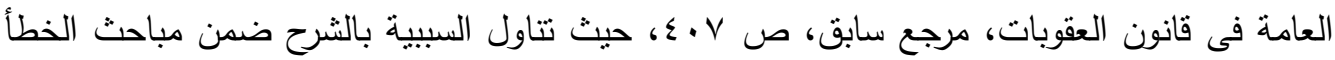

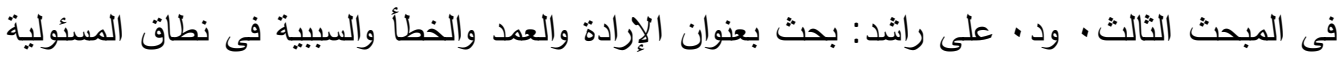

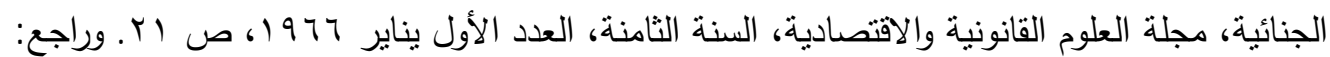

Domedieu de vabres (H.), Traité de droit criminal et de legislation Pénale comparee, 1947 No. 133 P. 82; Bouzat (P.) et pinatel (J.) , Traite de Droit Pénal et de criminalogie, I. 1963. No. 179. P. 190.

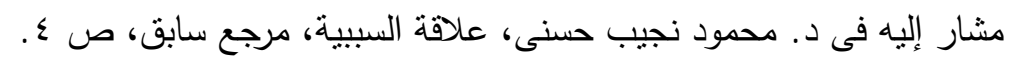

(9) William Wilson, Op. Cit., P. 95.

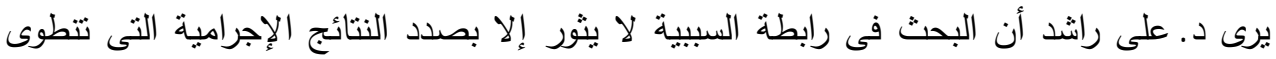

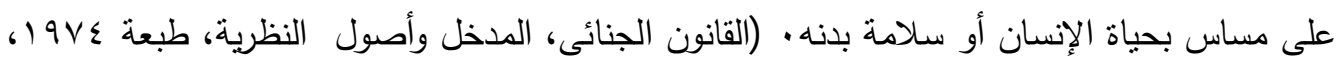

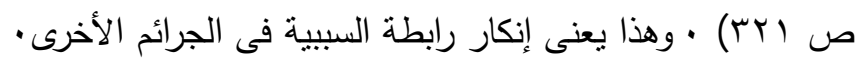

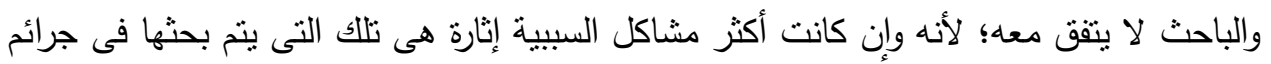

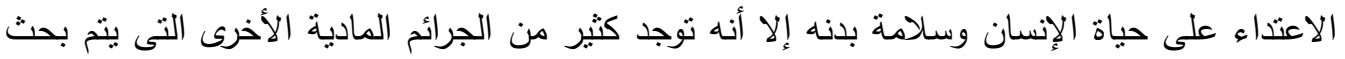

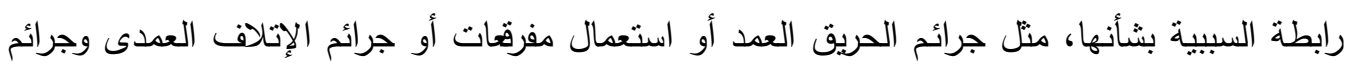


أوتشغيل ألــة معينـة،ولا تتـار رابطـة السببية فى الجـرائم التى لا يتعدى فيهـا السلوك الإجرامسى مرحلـة الثروع إلى تحقيق النتيجة الإجراميـة؛ باعتبار أن الجريمـة التى قارفها الجانى فى تلك المرحلة هى جريمة شكلية(ب 9) فيجب أن يكون السلوك الإجرامى المتمثل

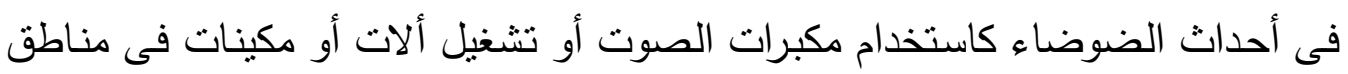

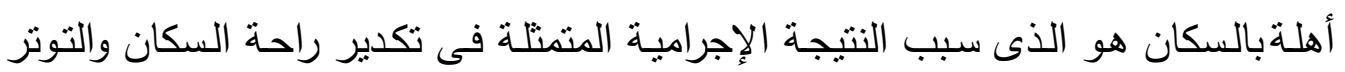

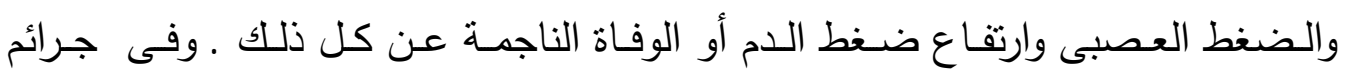
الخطر الفعلى لا نوجد نتيجة إجرامية مادية يعاقب المشرع على حدوثها وإنما يعاقب على نلى

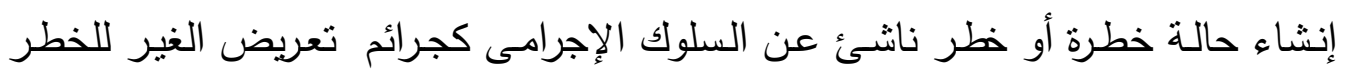

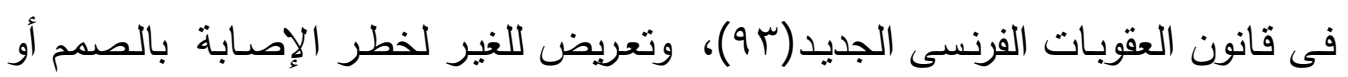

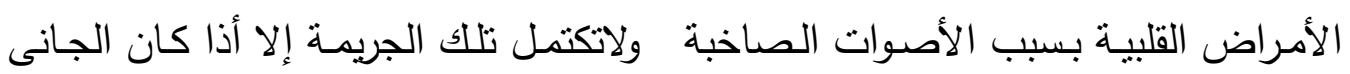
أنشاء بفعله قدرا من الخطر يسهل حدوث هذه الإصابة.

أخرى كثيرة، (راجع: د. محمد مصطفى القللى فى المسئولية الجنائية، القاهرة، مطبعة جامعة فؤاد

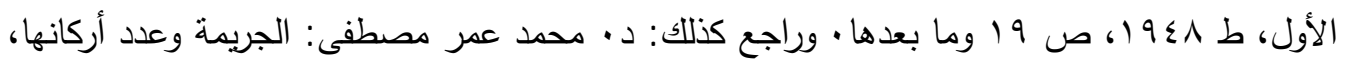

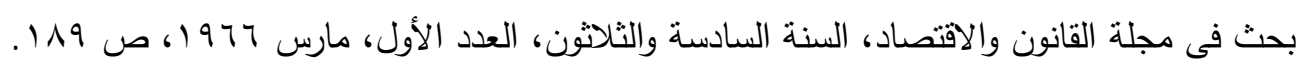

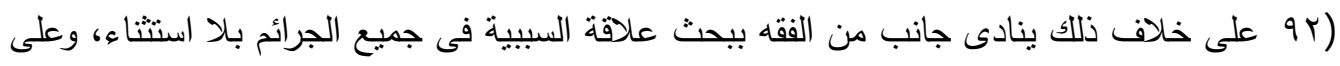

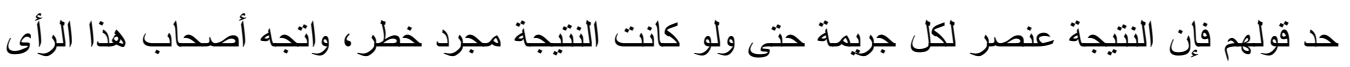

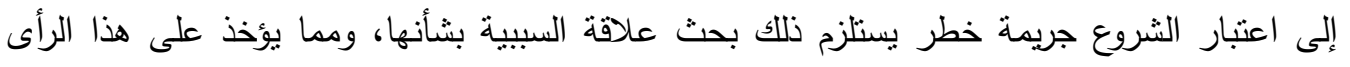

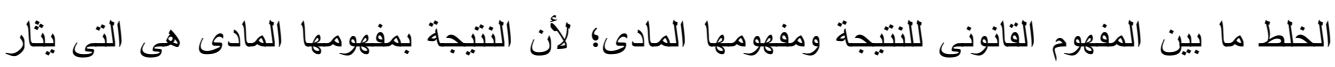

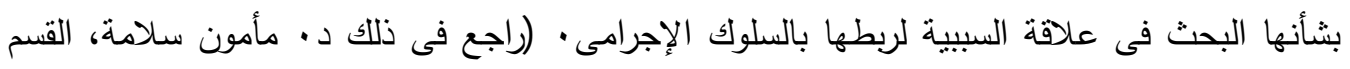

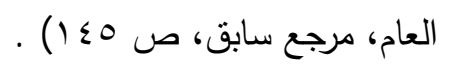

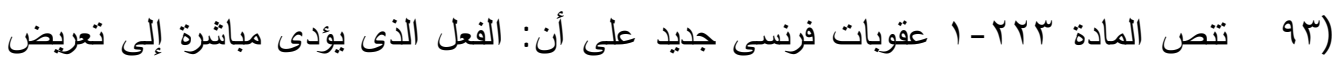

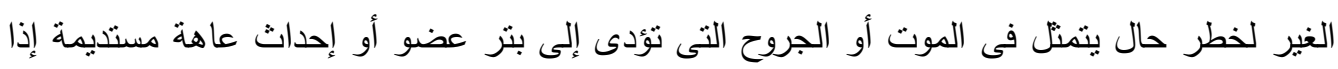

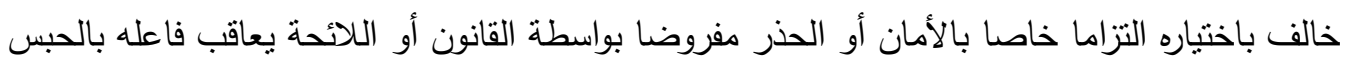

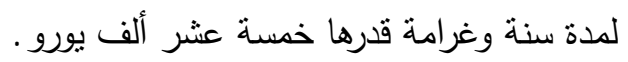




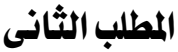

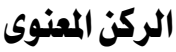

الركن المعنوى فى جريمة التلوث الضوضائى يتخذ إحدى صورتين هما العمد والخطأ و مدى اتجاه الإرادة إلى النتيجة هو الذى يحدد ما إذا كانت الجريمة عمديـة أو غير عمديـة ؛ فإذا أنصرفت الإرادة إلى النتيحـة المحظورة فضـلا عن الفعل كانت

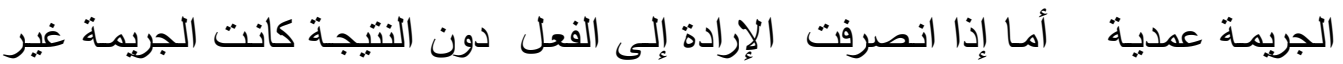
عمدية

وتطبيقا لذلك نص قانون العقوبات الأماراتى فى نص المادة رب على أن: " يتكون الركن المعنوى للجريمة من العمد أو الخطأ'(ع 9) . وعلى ذلك نتتاول فى فرع أول القصد الجنائى وفى فرع ثانى الخطأ غيرالعدى

\section{الفرع الأول}

\section{القصل الجنائى فى جرائم التلوث الضوضائى}

جرائم التلوث الضوضائى شأنها شأن باقى الجرائم العددية، لا تختلف عنها إلا فى وسيلة اقتراف الجريمة؛ حيث يلزم اتجاه إرادة الجانى إلى النتيجة مع علمه بالظروف

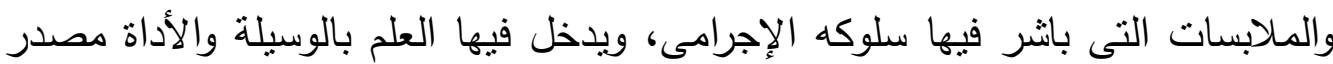
الصوت و المستخدمة فى الاعتداء (90) باتسرات

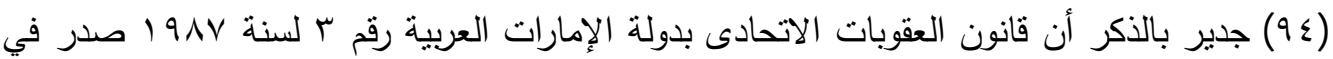
9

راجع تعريف القصد الجنائى فى القانون الجنائى الألمانى عند:

Nigel G. Foster - Satish sule. Assessoir: German legal system - Laws, German legal system and laws Oxford university press third edition 2002. P. 304

حيث عرفه بأنه الإرادة المتجه عن علم بالسلوك إلى نتيجة معينة يرغب الجانى فى تحقيقها وراجع القصد فى كل من فرنسا وإنجلترا وألمانيا عند :

Raymond Youngs: English, French \& German comparative law Youngs edition 1998, P. 238. 
والقصد يتكون من عنصرين هما العلم والإرادة على النحوالتالى:

\section{الفصن الأول}

\section{العلـهم}

فالعلم بواقعة ما شرط من الشروط الأولية لتوجيه الإرادة الإجرامية إليها؛ إذ هو يعتبر بمثابة المصباح الذى يضىء الطريق للإرادة المتجه نحو تحقيق النتيجة الإجرامية،

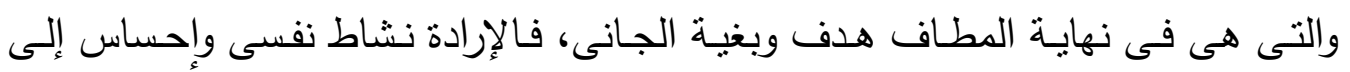

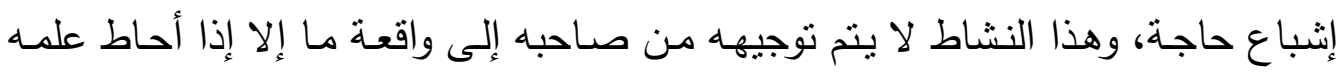
مسبقا بها وبكافة عناصرها وأركانها .

والوقائع التى يلزم علم الجانى بها هى الوقائع التى يحددها النموذج القانونى للجريمة، وأهم تللك الوقائع التى يجب أن يحاط بها علم الجانى هى السلوك الإجرامى

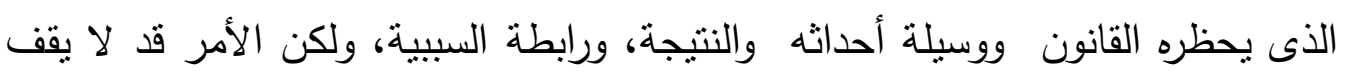
عند ذلك الحد بل قد يلزم توافر عنصر مفترض سابق على ارتكاب الجريمة فيجب العلم به(79) كذلك قد يدخل أيضا ضمن هذه الوقائع ما يسمى بالظروف المشددة التى تغير

$$
\text { وفى الفقه الإنجليزى راجع: (c) }
$$

Janet Dine and James Gabert: Cases and materials on criminal law, 4 th edition, 2003, PP. 146:147; William Wilson: Criminal law Doctrine and theory second edition 2003, P. 124; Alan Reed and Peter Seago: Criminal law sweet maxwell edition, 1999, PP. 57:65; Robert (B.) Seidman; A sourcebook of the criminal law of Africa London 1966. P. 108; Pradel (J.), Droit pénal comparé, Op. Cit., No. 178. PP. 253:254.

وراجع الخلاف الفقهى حول تحديد عناصر القصد الجنائى: د. محمود نجيب حسنى: النظرية العامة

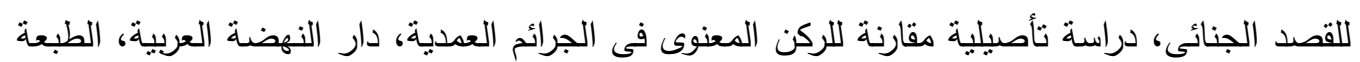

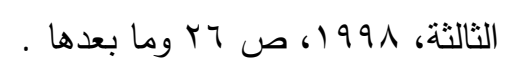
(79) العناصر المفترضة كصفة الإنسان الحى فى جريمة القتل أو صفة المرأة الحامل فى جريمة الإجهاض،

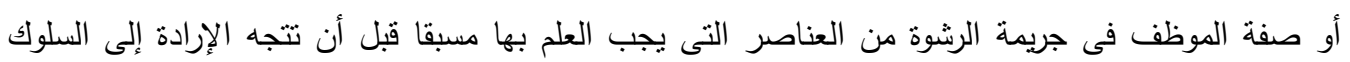

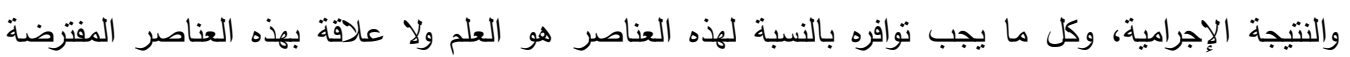


من الوصف القانونى للجريمة، فيجب أن بحاط بها علم الجانى، لأنها أصبحت ركنا فى

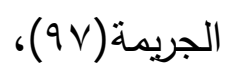

\section{1 - العلم بموضوع الحق المعتدى عليه:}

الحق الذى يعترف به ويحميه المشرع الجنائى لابد لله من موضوع ينصب عليه،

وهو المحل الذى يتعلق بـه مضمون هذا الحق الذى يقع عليه فعل الجانى، ويتحقق فيه

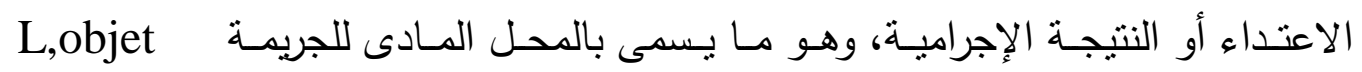
materiel du delit وأحيانا بندمج الحق فى شخص صاحب الحق أو شخصية المجنى عليه، ويصبح كلاهما أمرا واحدا(919)، ويكون ذلك بجلاء فى الاعتداء على الحقوق اللصيقة بشخص الإنسان

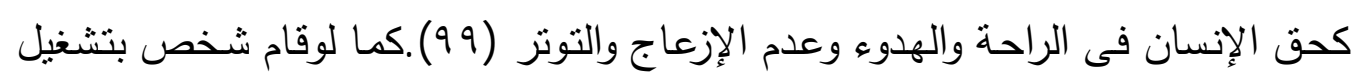
ألة تصدرت صونا شديدا طوال الليل.

والإرادة؛ لأن الإرادة لا تنتطيع السيطرة عليها؛ لأنها سابقة فى وجودها على الجريمة نفسها، بل سابقة على المراحل التحضيرية للجريمة. بخلاف ذلك ذهب البعض إلى اعنبار كون المرأة حامل ركن فى الجريمة فى القانون تأسيسا على نصوص

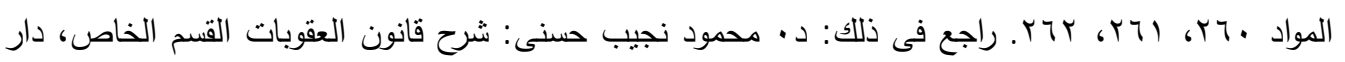

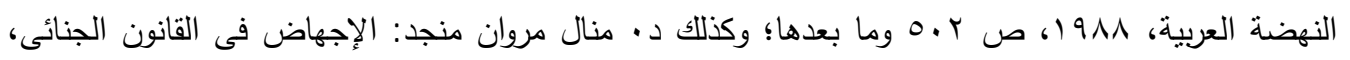

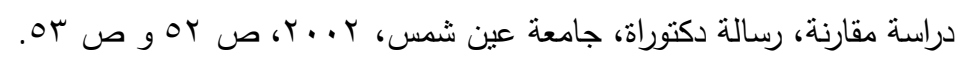

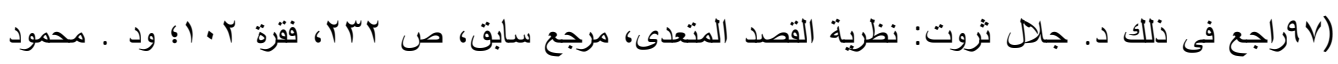
نجيب حسنى: القصد الجنائى، مرجع سابق، ص به ه؛ ود • محمد زكى محمود : آثار الجهل والغلط فى المسئولية

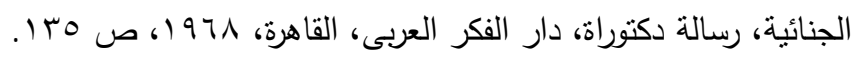

(१^) Dalegu (T.), Op. Cit., N. 167.

حيث يقول:

Dans certains infractions, il Porait que le sujet passif et 1,objet materil s,identifient.

(99 ) يرى بعض الفقه المصرى أن موضوع الحق المعتدى عليه، أى الموضوع المكون للجريمة يمكن أن يكون شخصا كما يمكن أن يكون شيئا، وبالنسبة للشخص فإنه لابد وأن يكون آدميا لا شخصا

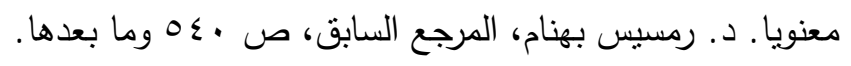


؛ وحتى يتوافر القصد الجنائى فى حق الجانى يجب أن يكون قد قصد الاعتداء

على هذه المصالح سالفة الذكر، وأن يقع فعله الإجرامهى على ذلك المحل المتمثل، أما فى صحة إنسان حى،أو تكدير راحته أو التوتز العصبى الذى بصيبه. ف فإذا انصب فعل الجـانى الإجرامسى على صـحة إنسان بعتقـد أن الحيـاة فارقته فـلا يتـوافر القصد الجنائى لديه( . . ( )، أو الشخص الذى يدير ألة فى مكان معتقدا أنه مكان غير سكنى بالمخالفة للحقيقة.

وهذا الجهل أو الغلط ينفى القصد الجنـائى فتمتتع المسئولية الجنائية لانعدام الصورة

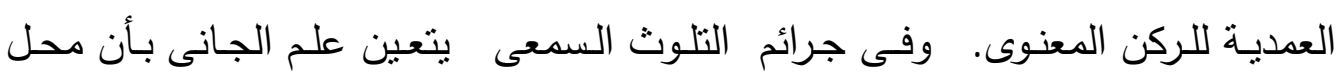
الاعتداء إنسان حى، وأن من شـأن فعلـه أن يتضمن مساسا بحقه فىى السـلامة البدنيـة والنفسية والحياة، وأن يكون عالمـا بماهيـة الوسيلة، أو الأداة المستخدمة فى الاعتداء، وإن من شأن ذلك إصابته بمرض أو وفاته

كذلك إذا مـا أقدم طبيـب على وضـع جسد إنسان حى فى غيبوبـة؛ بجوار ألة توليد الكهرباء فى المستثفى معتقدا أن جسده فارقته الحياة، فلا بسأل عن جريمة تلوث سـعى عمدى إذا ماأصيب المـربض بالصمم لانتفاء العلم لديـه، وبالتالى حدوث غلط جوهرى انصب على واقعة يتطلب القانون العلم بها كى يعد القصد الجنائى، متوافرا لدى الجانى وأن كان ذلك لا ينفى المسئولية الجنائية غير العمدية

1..) Garçon (E.), Art 295 No. 49.

ود · محمود محمود مصطفى: القسم الخاص، ص .10، أما إذا حدث العكس وأقدم شخص على قتل آخر، ولكن الحياة قد فارقته قبل فعل الاعتداء فإننا نكون بصدد جريمة من الجرائم

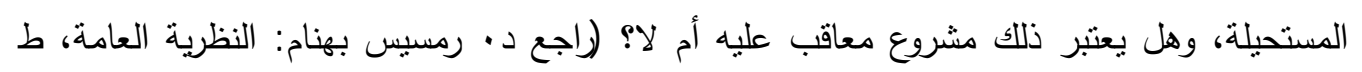

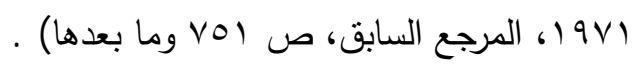




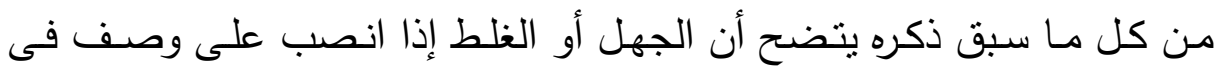

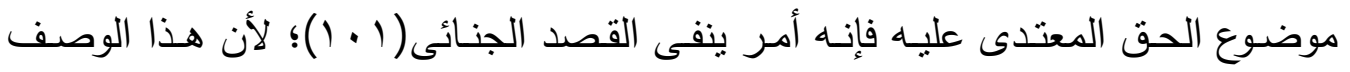
يدخل عنصرا موضوعيا فى البنيان القانونى للجريمـة، وحتى يمكن القول بتوافر القصد الجنائى للدى الفاعل يجب أن يكون الجانى عالمـا بهذا العنصر الموضوعى علمـا فعليا

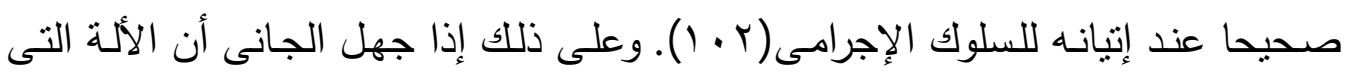

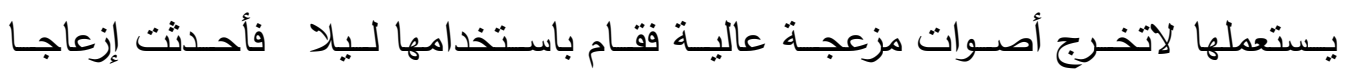
وضوضاء تضرر الكثير من الأشخاص منها فإن القصد الجنائى يكون منتقيا لديه وإن يعاقب عنها بوصف الخطأ غير العمدى.

\section{r - العلم بخطورة السلوك الإجرامى على الحق محل الحماية:}

براد بالسلوك نشاط الإنسان فى العالم الخارجى القائم حوله، سواء تمثل فى حركة الجسم أو عضو من أعضائه بشكل إيجابى أو تمثل بسكون جسمانى أو امتتاع، أى هو طريقة

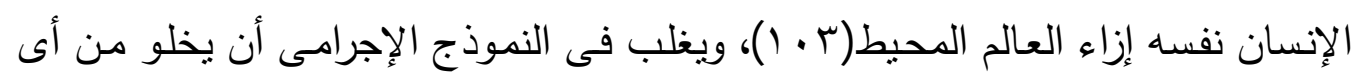

(1 (1) وتطبيقا لذلك قضى إذا كانت المحكمة قد أدانت المتهم فى جريمة إخفاء أثنياء مسروقة على

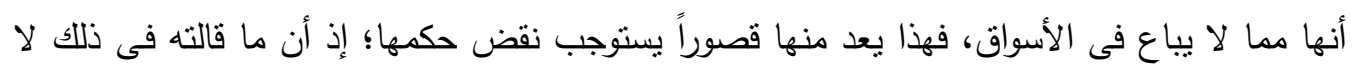

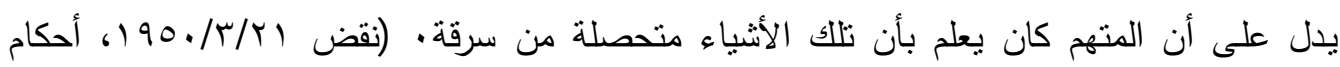

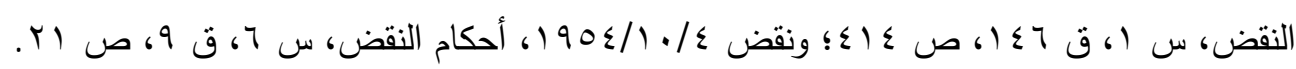

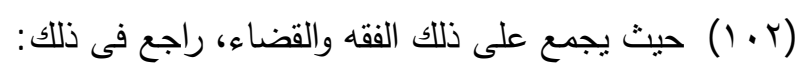

Bouzat (P.) , Traité théorique Partique de droit Pénale 1951 P. 147; Vidal (G.) et Magnol (J.), Cours de droit criminel et de sciences pénitentiaire T. I P. 342; Roux, Cours de droit criminel Francais T. I. P. 180.

مشار إليه فى د. محمد زكى محمود: آثار الجهل والغلط فى المسئولية الجنائية، مرجع سابق،

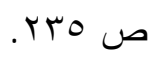

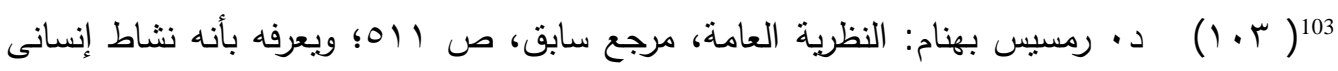

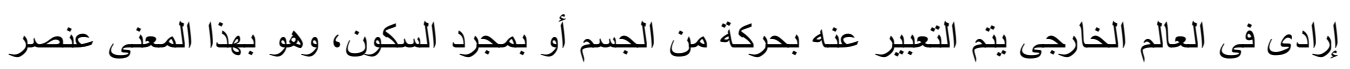

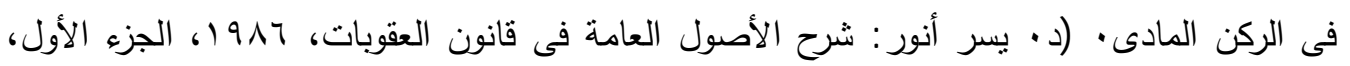

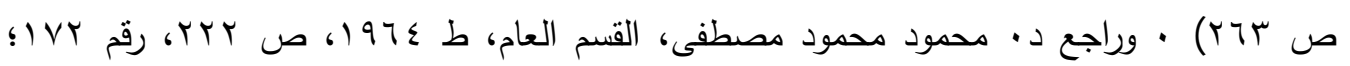


تحديد لأداة معينـة يلزم استخدامها فى تتفيذ الجربمة، فيكون مفهوما إمكان ارتكاب إياهـا

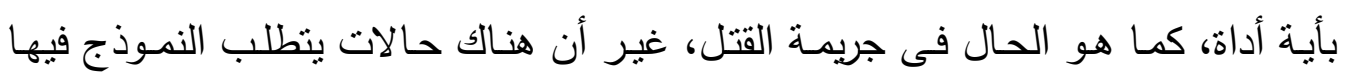

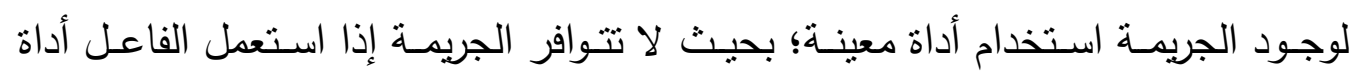

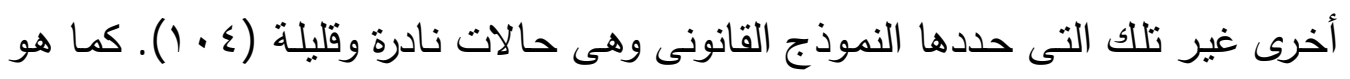
الحال فى استخدام الباعة الجائلين لمكبرات الصوت للإعلان عن بضائعهم . أو استخدام ألة التتبيه ليلا ودون مقتضى الينى

وعلى ذلك فإن العلم بحقيقة السلوك الإجرامى وما يشكله من خطورة على الحق

الذى يحميه القانون يعتبر شرطا لازما لتوافر القصد الجنائى لدى الجانى؛ باعتبار ذلك

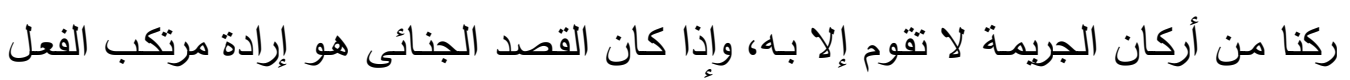

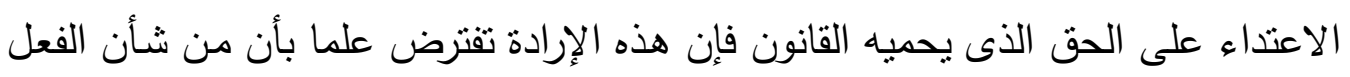

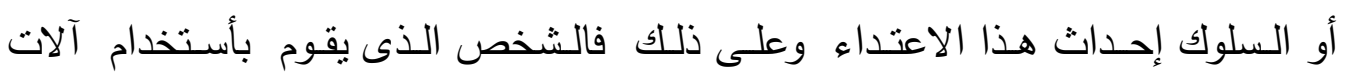

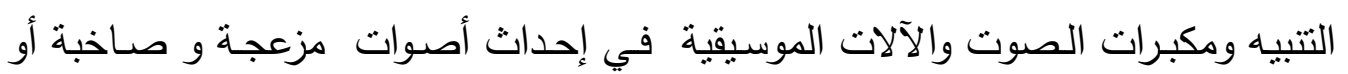
اهتزازات وذبذبات صوتية يجب أن يعلم أن من شأن ذلك أن يشكل خطورة على الهى حق الإنسان فى الراحة والسكون والهدوء والمساس بسلامتة النفسية والجسدية. وأعتداء على المصالح التعليمية

\section{r - العلم بوسيلة السلوك فى جرائم التلوث السمعى}

\section{L instrument de la conduite}

فى جـرائم التلوث السمعى يستلزم المششرع استعمال الجـانى أداة أو ألـة فـى نتفيذ

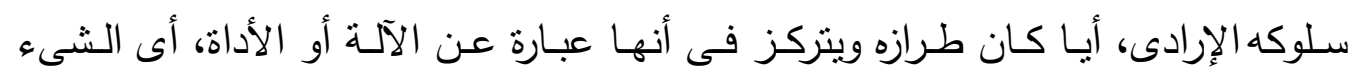

وراجع د. جلال ثروت، رسالته فى الجريمة المتعدية أنظر معنى السلوك الإجرامى، رقم ب ب، ص 10 وما بعدها. ( ـ • (1) وعلى هذا الأساس يقسم بعض الفقه الجرائم إلى جرائم أداة مطلقة وجرائم أداة خاصة: راجع

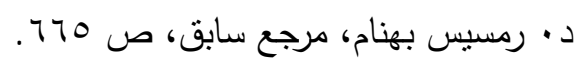


المادى الذى له كيانه الذاتى المستقل والمتميز عن نفس السلوك(0 ـ ( )، أيا كانت الكيفية

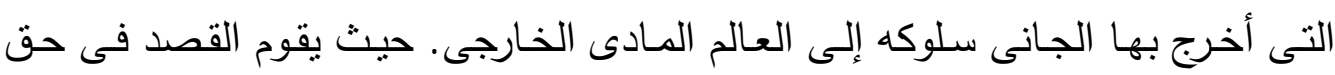
الجانى من توافر العلم بهذه الوسيلة وهى مكبرات الصوت أو الألات الصاخبة وأن من الهن شأن أستخدامها أحداث الضرر المنمنل في إزعاج وإقلاق الأخرين. ويجب الحذر مـن الخلط بين الفعل Azione والوسيلة Mezzo؛ ذلك أن الفعل هـو الحركة العضلية التى تخرج إلى العالم الخارجى ويحفل بخروجها القانون، أمـا الوسيلة

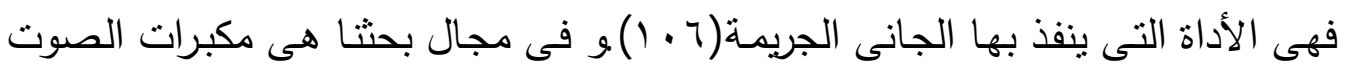

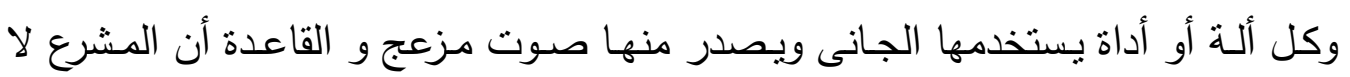

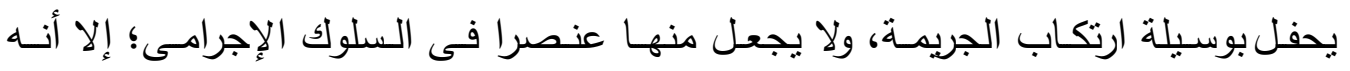

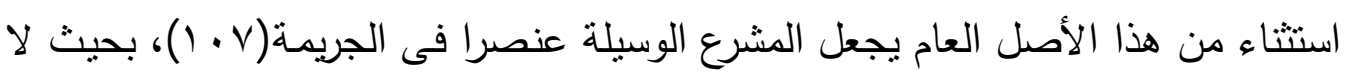

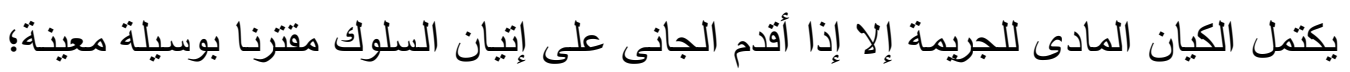

1.0) Grispini, Op. Cit., P. 88 No. 148.

مشار إليه فى د. محمد زكى محمود: آثار الجهل والغلط فى المسئولية الجنائية، رسالة

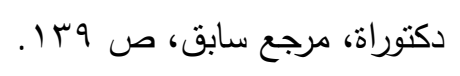

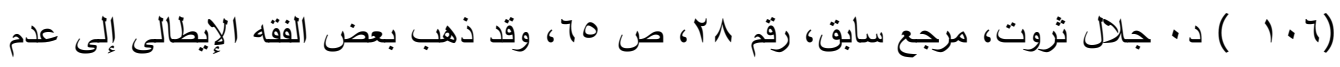

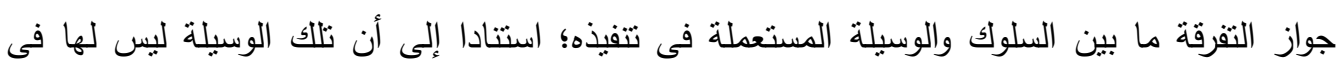

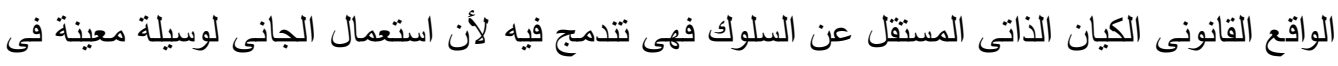

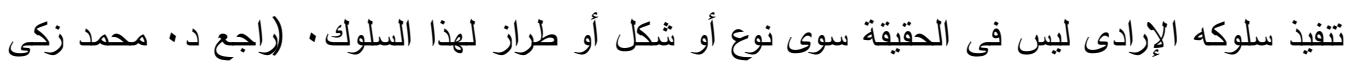

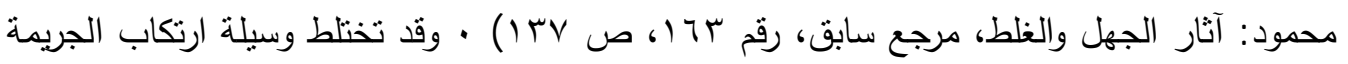

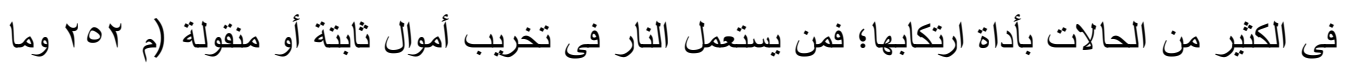

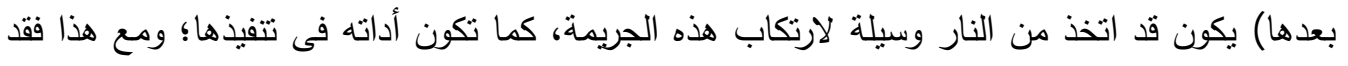

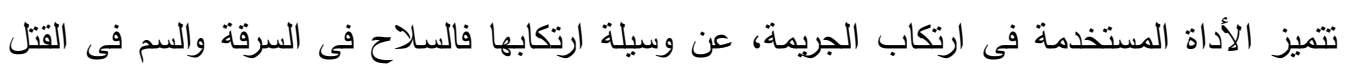

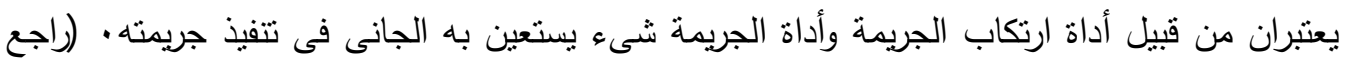

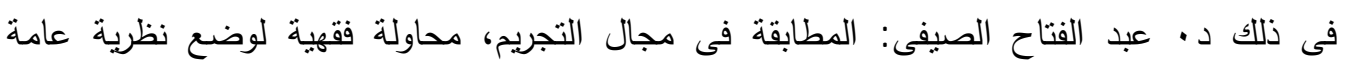

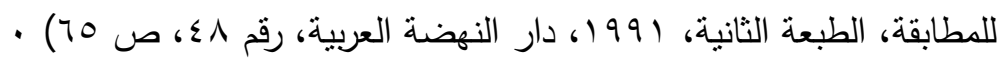

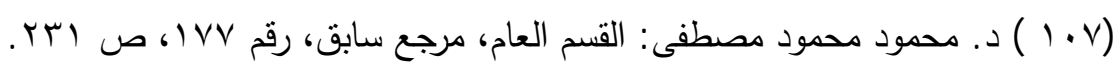


وفى تلك الحالة تعتبر الوسيلة عنصرا مفترضا فى السلوك الإجرامى، يتعين علم الجانى بـه حتى يقوم القصد الجنائى فى جانبه . ففى جرائم التلويث السمعى جعل المشرع من

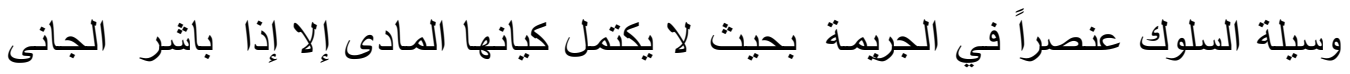

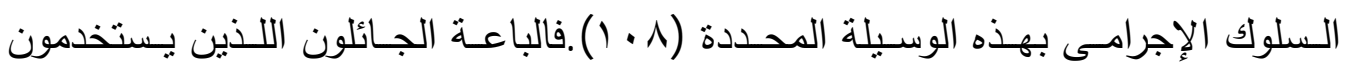
مكبرات الأصوات للإعلان عن بضائعهم يجب أن يعلمون أنهج يستخدمون هذه الألات

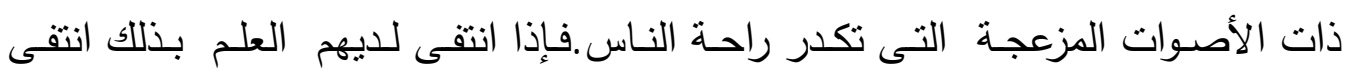
القصد لديهم بالتبعية.

\section{ع - العلم بالمكان الأى باشر الجانى فيه السلوك الإجرامى:}

الأصل أن المشرع لا يعتد بمكان السلوك Le lieu de la conduite ولا مكان حدوث

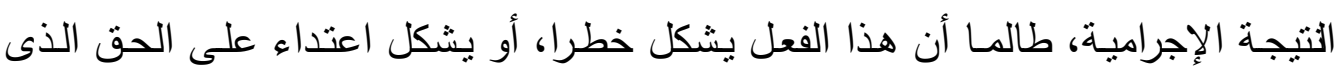
يحميـه الشارع(9 • (1)، وبصفة عامـة لا يجعـل المشرع الجنـائى، مـن العلم بمكان إتيـان

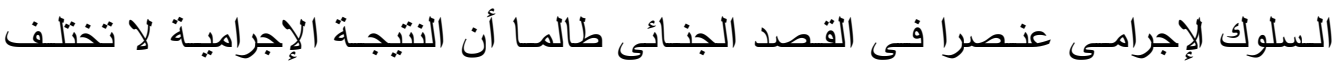

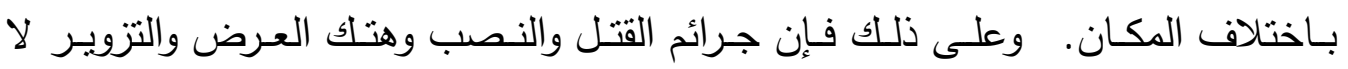
تختلف إليها نظرة المشرع بـاختلاف المكان الذى باثـر فيـه الجـانى سـوكه الإجرامسى، فجريمة استعمال المكبرات الصوتية تتوافر بحق الجانى بصرف النظر عن مكان إتيان

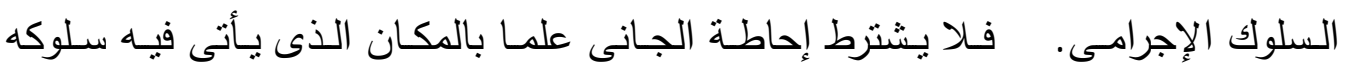

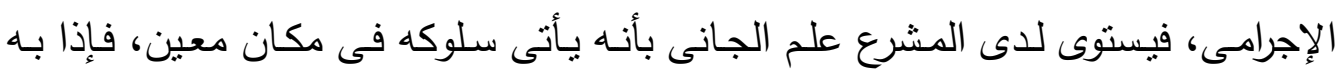
يقارف سلوكه فى مكان آخر ، فقى الحالتين يعد القصد الجنائى منوافرا لديه.

واستثناء من هذا الأصل العام يستلزم المشرع لتكامل الكيان الموضوعى للجريمة أن يقارف الجانى سلوكه الإجرامى فى مكان معين، فإذا ما قارف الجانى سلوكه هذا

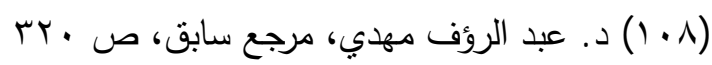

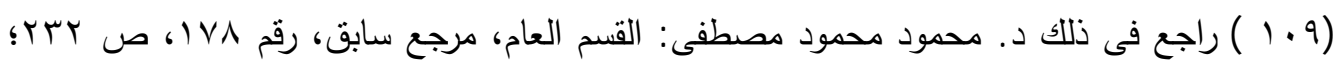

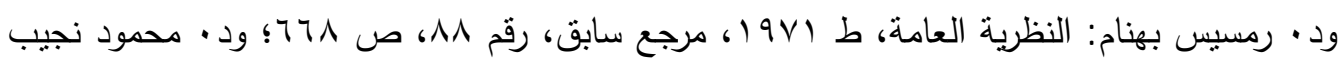

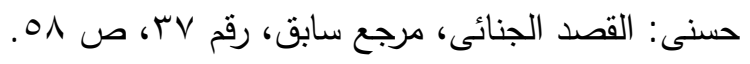


فى مكان آخر فإن الجريمة لا تقوم فى حقه، ولا يتكامل بنيانها الموضوعى( • (1)،

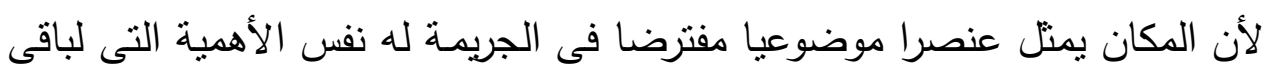
العناصر الموضوعية الأخرى؛ لذلك فحتى يمكن القول بتوافر القصد الجنائى لدى الجانى فى جرائم المكان الخاص يجب أن يحيط علما بأركان الجريمة؛ ومن ثم فإن

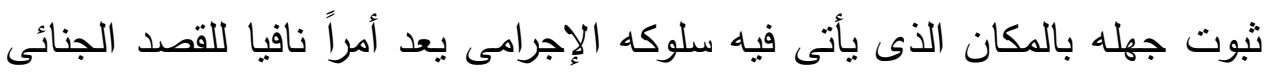

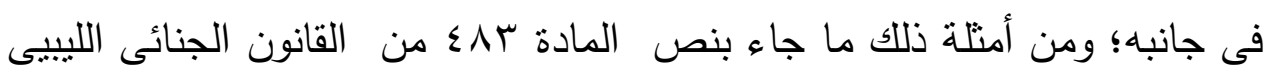
على أن (كل من أطلق عيارات نارية أو أشعل ألعاباً نارية أو ألقى صواريخ أو أحدث لهيباً أو انفجارات في حي مأهول أو في أماكن مجاورة له أو في طريق عام

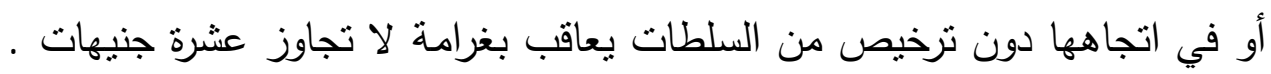

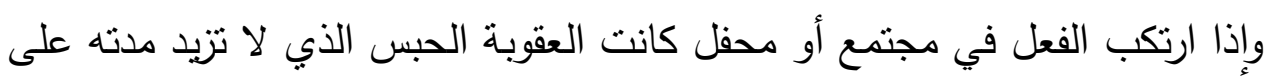

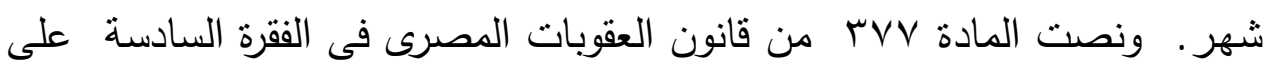

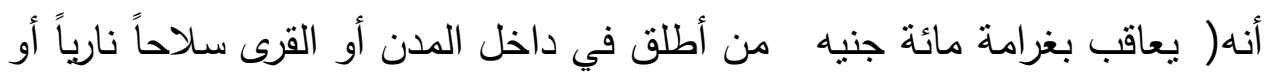

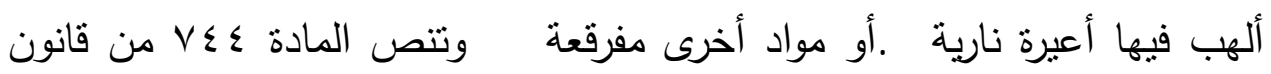

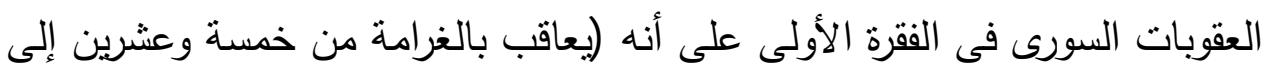
مائة ليرة من أحدث ضوضاء أولغطا على صورة تسلب راحة الأهلين وكذا من حرض على هذا العمل أو أشترك فيه و من أطلق في داخل المدن أو القرى سلاحاً نارياً أو ألهب فيها أعيرة نارية أو مواد أخرى مفرقعة. ومن أمثلة ذلك جريمة المادة

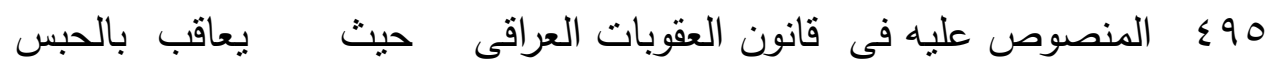
مدة لا تزيد على شهر او بغرامة لا تزيد على عشرين دينارا:

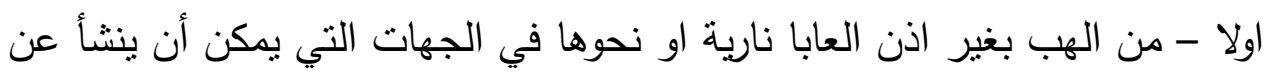

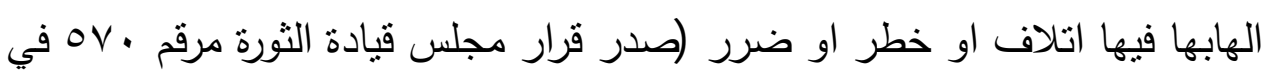

(11) يطلق الفقه على هذه الجرائم جريمة المكان الخاص: (راجع د. • محمد زكى: آثار الجهل والغلط

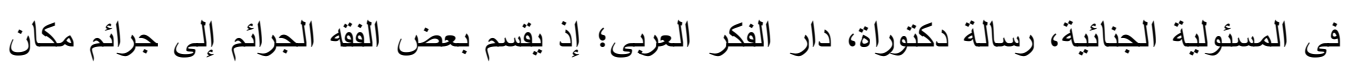

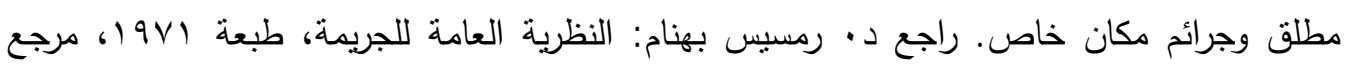

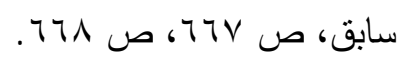




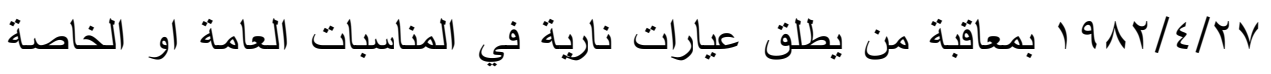
داخل المدن والقرى والقصبات دون ان يكون مجازا بذلك من قبل سلطة مختصة، بالحبس مدة لا تقل عن سنة واحدة ولا تزيد على ثلاث سنوات. نشر في الوقائع

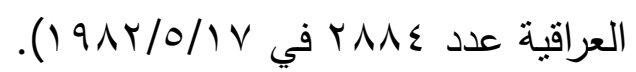

ثانيا - من أطلق داخل المدن أو القرى أو القصبات سلاحا ناريا او علبة نارية او

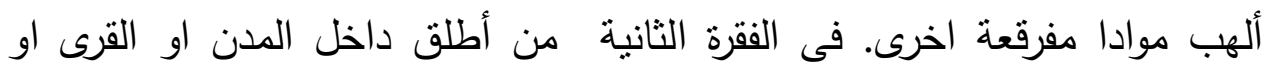
القصبات سلاحا ناريا او علبة نارية . يعاقب بغرامة لا تزيد على عشرين دينارا.

ه - العلم بزمان ارتكاب السلوك الإجرامى: القاعدة العامـة هـى أن المشرع لا يعتد بزمن ارتكاب الجانى للسلوك الإجرامى؛

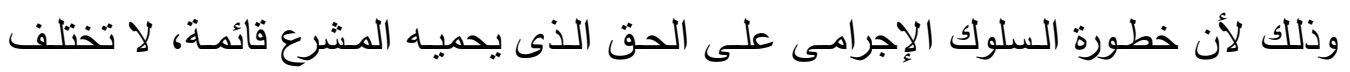
باختلاف الزمن الذى قارف الجانى فيه سلوكه الإجرامى، فجرائم القتل والضرب والسرقة

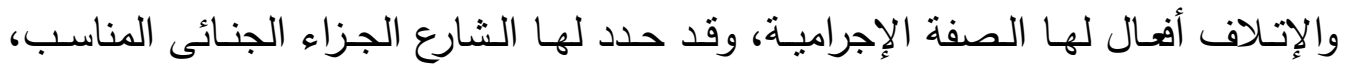
بصرف النظر عن الوقت التى ترتكب فيه ، فسواء قارف الجانى سلوكه الإجرامى ليلا أم نهارا فى زمن الحرب أم فى زمن السلم فسلوكه معاقب عليه.

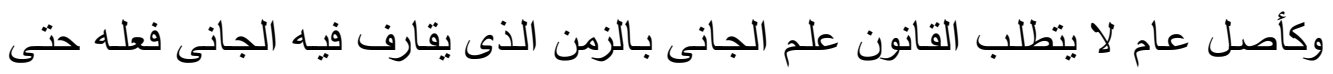
يتوافر القصد الجنائى لديه سواء علم بالزمن أم لم يعلم (1) (1).

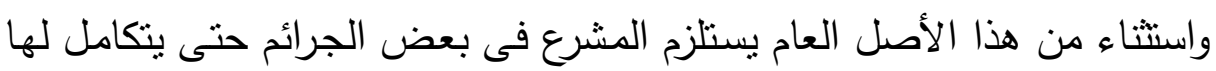

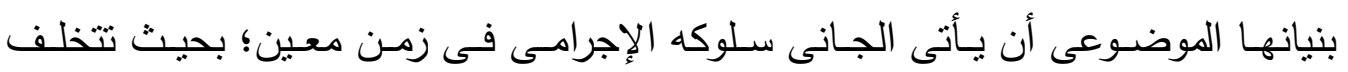
الجريمة بالوصف المنصوص عليه فى النموذج القانونى إذا قارف الجانى سلوكه فى غير

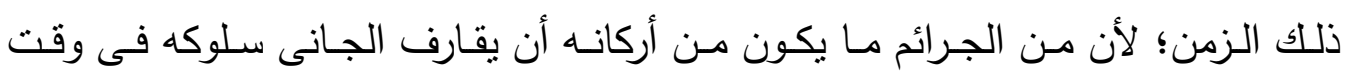
معين (1) (1) (1).

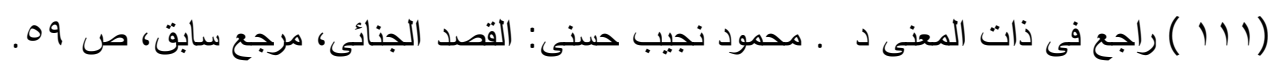

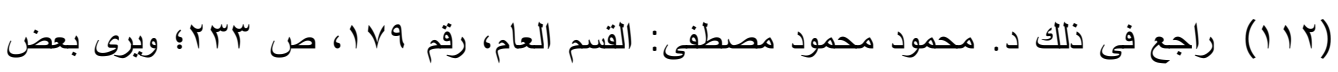
الفقه المصرى أنه لا يعد من عناصر السلوك الإجرامى بحسب الأصل وسائل هذا السلوك ولا زمانه ولا لإنا

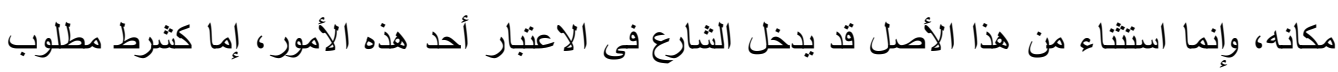


والعلة من خروج المشرع على هذا الأصل أن الفعل أو السلوك الإجرامى لا يمثل

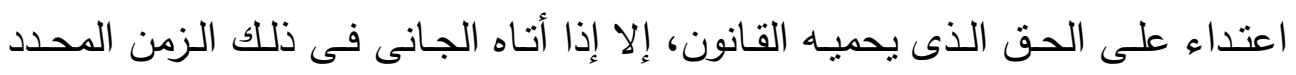
بالنموذج القانونى للجريمة؛ إذ يعتبر الزمن المحدد بالنموذج القانونى عنصرا مقترضا

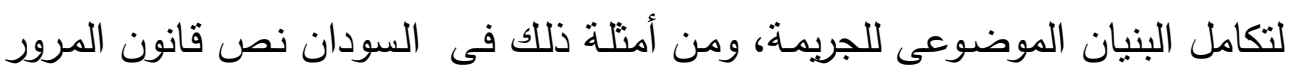

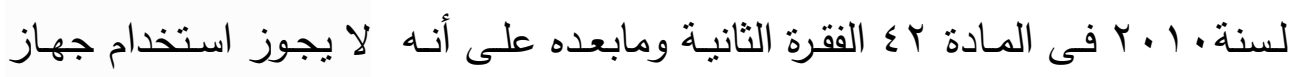
التتبيه أو أي آلة أخرى فيما بين منتصف الليل والساعة الخامسة والنصف صباحاً ولا

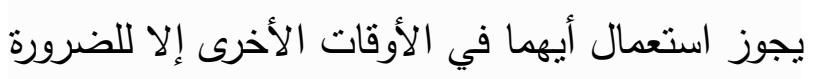

$$
\begin{aligned}
& \text { 4 - العلم بالقانون فى جرائم التلوث السمعى: }
\end{aligned}
$$

الجهل والغلط فى القانون الجنائى يعفى من المسؤلية الجنائية فى كثير مـن الحالات

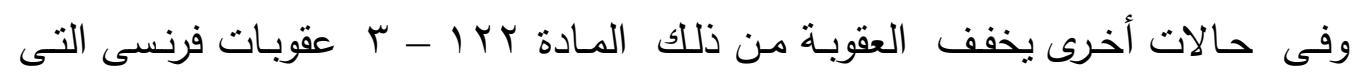
نصت على أنه: لا يسأل جنائبا الثخص الذى يثبت أنه اعتقد نتيجة غلط في القانون لم

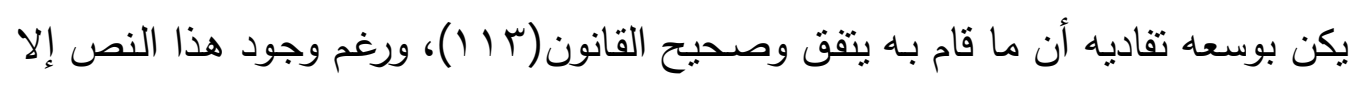

للعقاب، وإما كظرف مقتض للتشديد. (راجع فى ذلك د. عبد الفتاح الصيفى: المطابقة فى مجال

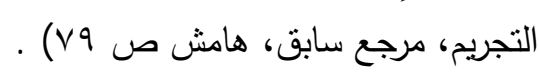

11r) N`est pas pénalement responsable la personne qui justifie avoir cru par une erreur sur le droit qu'elle n`etait pas en mesure d`eviter pouvoir légitimement accomplir l'acte".

والجدير بالذكر أن نص المادة السابقة قد مر بمراحل بين الإلغاء والنص عليه فقد؛ ورد

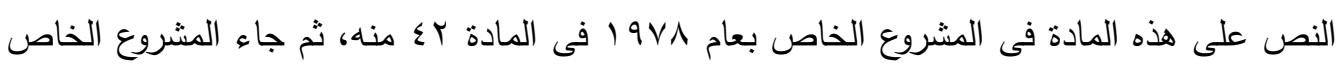

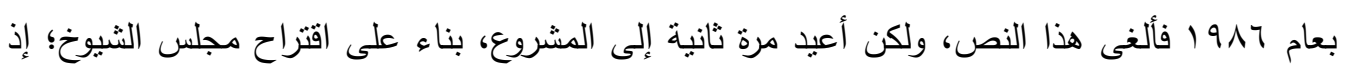

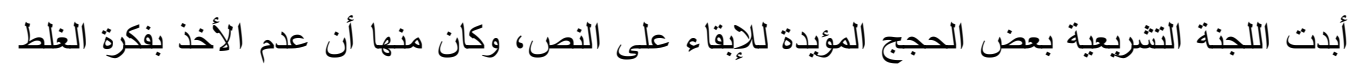

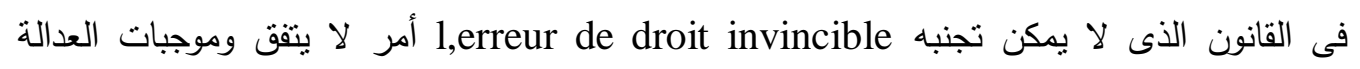

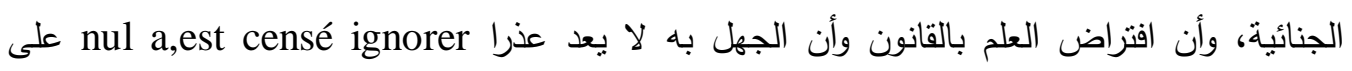

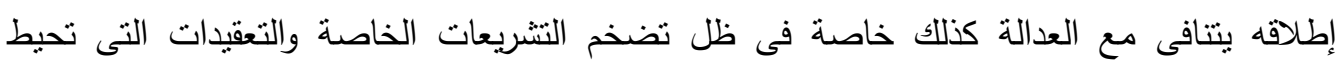

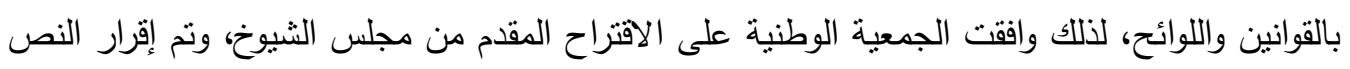

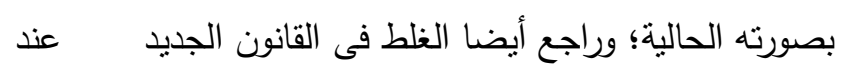


أن محكمة النقض قد نتددت فى تطبيقه ونقضت العديد من أحكام البراءة(ع (1) و تحت عنوان الطبيعة الملزمـة للقانون العقابى

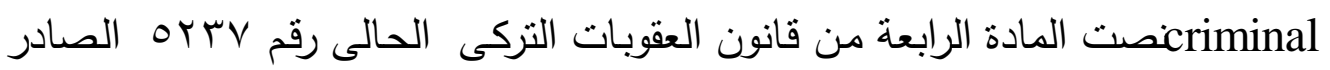

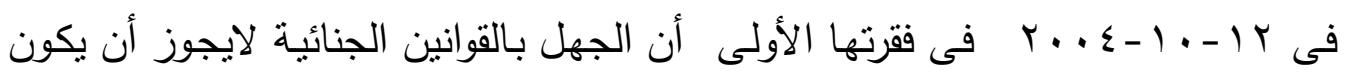

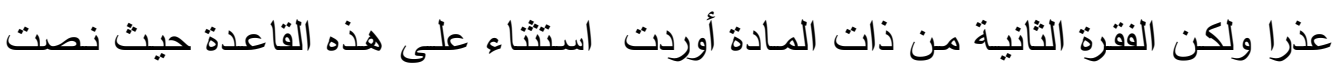

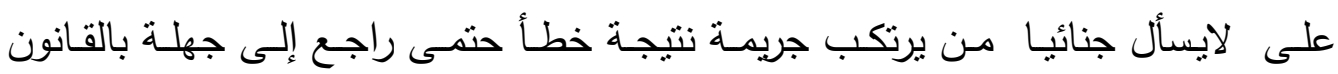

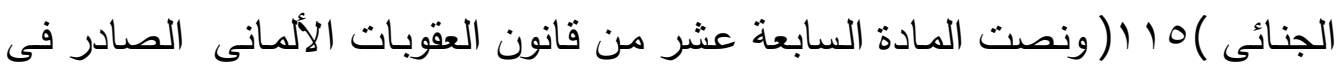

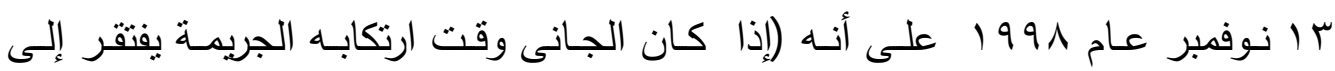
الوعى بأنه يتصرف بشكل مخالف للقانون فيعتبر أنه تصرف دون ذنب إذا كان الخطأ حتمى لا مفر منـهـووعلى ذلك فإذا جهل المتهم وجود نص يجرم استخدام مكبرات

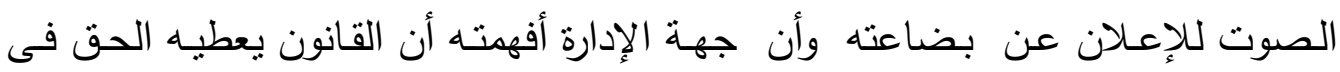

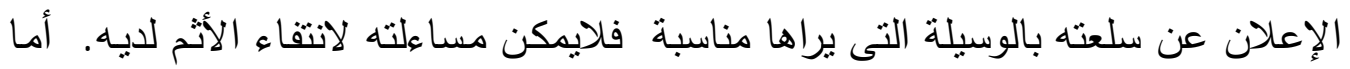

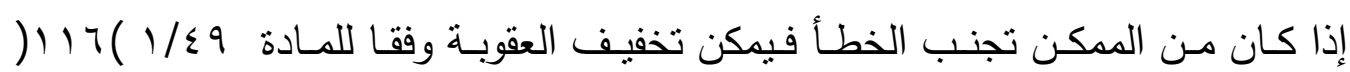
ونـصت المـادة الحاديـة والعشرين مـن قـانون العقوبـات السويسرى الصادر عـام VI I

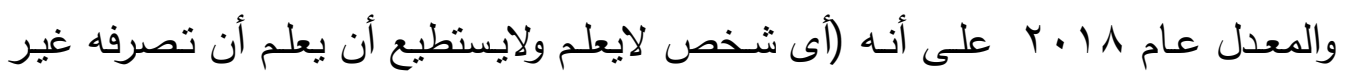

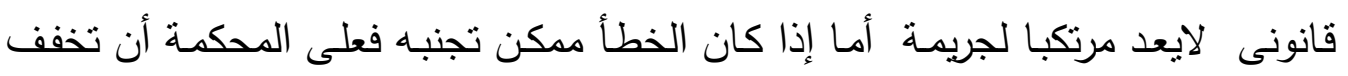

1,erreur en nouveau droit pénal: Levasseur (G.) , chavanne (A.) montreuil (J.) Bouloc (B.), Droit pénal général et procédure pènale éd Dalloz 1999 No. 190. P. 72.

) $\backslash$ । ) Crim II Octobre 1995 Bull. Crim No. 310. D. 1996. P. 15; Crim 15 Novembre 1995, Bull. Crim No. 350.

110) ARTICLE 4- (1) Ignorance of the criminal laws may not be an excuse. (2) However, a person who commits an offence through an inevitable mistake due to his ignorance of the law may not be kept criminally responsible from such offence.

(117 ) If at the time of the commission of the offence the offender lacks the awareness that he is acting unlawfully, he shall be deemed to have acted without guilt if the mistake was unavoidable. If the mistake was avoidable, the sentence may be mitigated pursuant to section 49(1) 


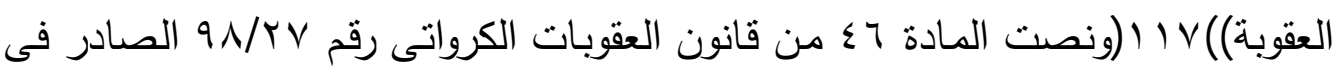

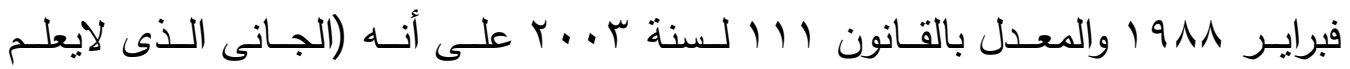

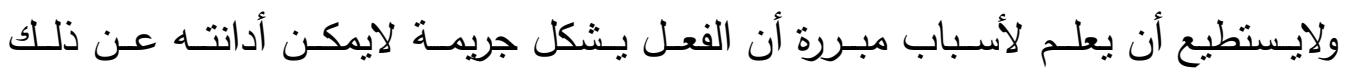

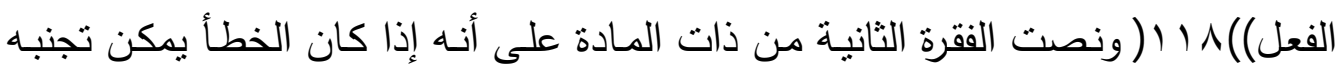

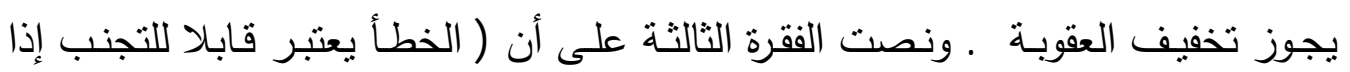

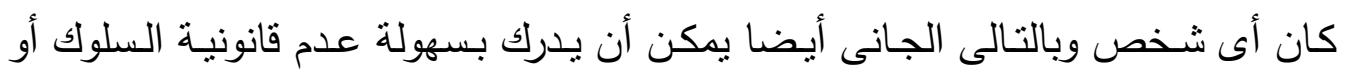

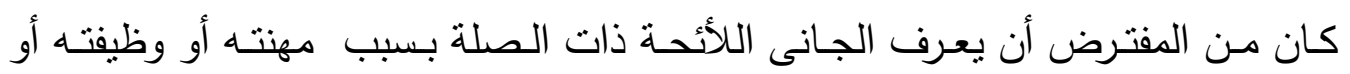

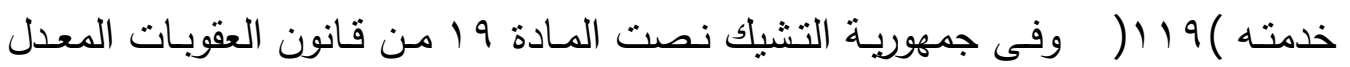

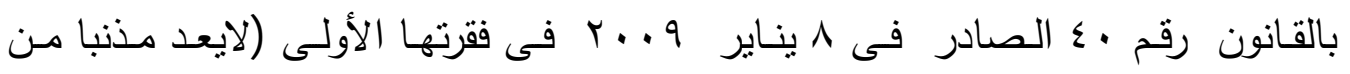
يجهل عدم شرعية سلوكه أو سلوكها أثثاء ارتكابه الفعل بشرط ألا يكون قادرا على تفادى الخطأ (ونصت فى الفقرة الثانية منها على أن (الخطأ يمكن تجنبه إذا كان واجب الإلمام

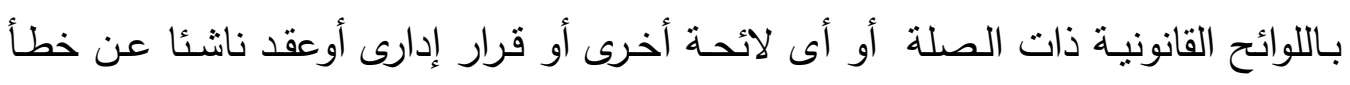

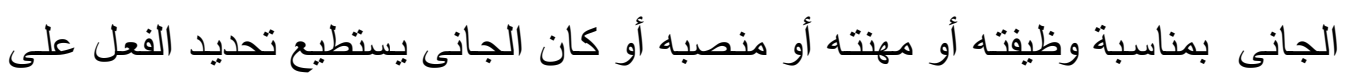

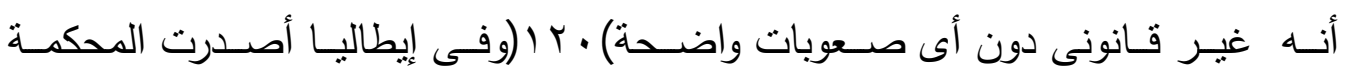

IIV -) Art. 21 Any person who is not and cannot be aware that, by carrying out an act, he is acting unlawfully, does not commit an offence. If the error was avoidable, the court shall reduce the sentence.

(1)^) art 46 : The perpetrator who, for justified reasons, does not know and could not have known that the offense is prohibited shall not be culpable.

$11 \wedge$ ) If the mistake is avoidable, the punishment may be mitigated.

119)- ) A mistake shall be deemed avoidable if anyone, and thus also the perpetrator, could have easily grasped the unlawfulness of the conduct, or if the perpetrator was supposed to know the relevant regulation because of his profession, occupation or service.

(IY.) - art 19 (1) Whoever is unaware of illegality of his/her conduct during commission of such act, does not act culpably, provided that he/she could not have avoided the error. (2) The error could have been avoided if the duty to acquaint with the relevant legal regulation resulted for the offender from the law or another legal regulation, administrative decision or a contract, from their 


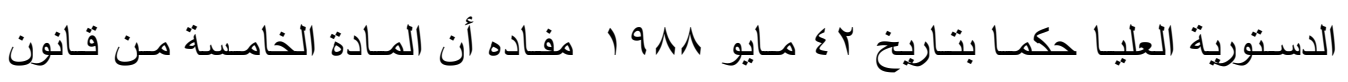
العقوبات الإيطالى التى نتص على أنه ل لاجهالة لأحد بالقانون هى غير دستورية بصورة

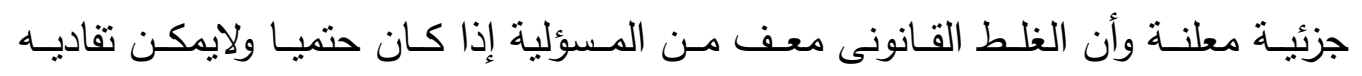

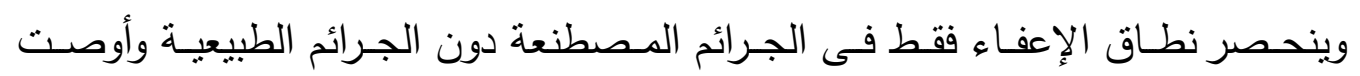
بضرورة تعديل نص المادة سـالفة الذكر ليكون كالتالى (أن الجهل بالقانون لايعفى من المسؤلية إلا إذا نتج عن غلط حتمى لايمكن تفاديـه ( I I ) وتطبيقا لذلك فإن جرائم التلوث السمعى هى من الجرائم المصطنعة فى إيطاليا وبالتالى يمكن إعفاء المتهم

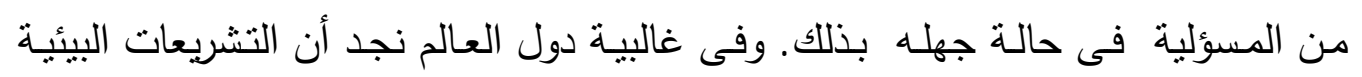
والنصوص العقابية التى تضمنتها القوانين والمتعلقة بالتلوث السمعى مستحدثة ولا يتوافر

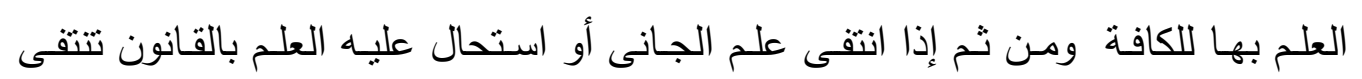

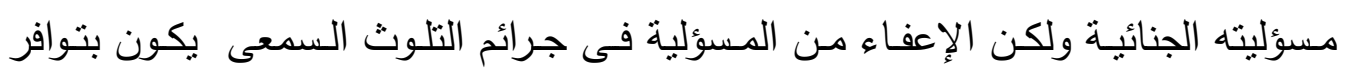
ثلاث شروط طبقا لتحليل النصوص السابقة على النحو التالى:

الشرط الأول: أن يقع الغلط أو الجهل على قاعدة قانونية التهات une rélge de droit

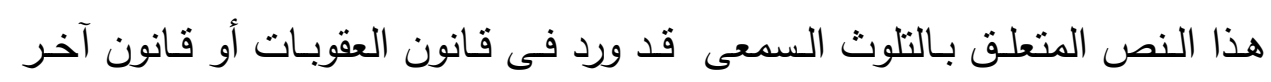
والتى تشكل عنصر من عناصر تكوين الجريمـة، وسواء انصب هذا الغلط على

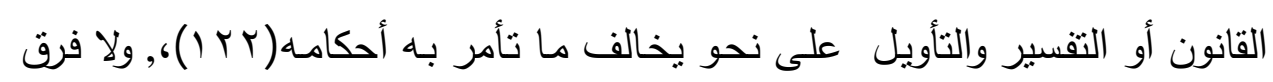
فى ذلك بين القانون واللائحة وبيستوى أن تكون الجريمة موضوع النص الذى جهل

employment, occupation, position or function, or if the offender could identify the act as illegal without any apparent difficulties (Y) ( ) - فى ذلك راجع د. مصطفى العوجى . القانون الجنائى الجزء الثانى المسؤلية الجنائية

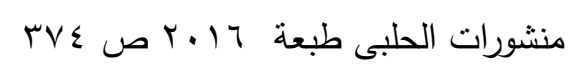
( أن ( T ) العلم بالقانون يقتى العلم بالتفسير الدقيق للنص الذى خولفت أحكامه فلا يجوز للمتهم

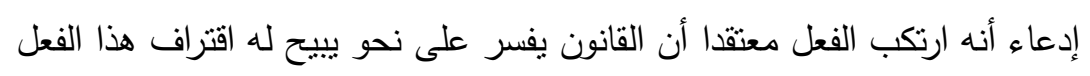


بـه الجانى عمدية أو غير عمدية سلبية أو إيجابية(r T) ()، وجرائم التلوث السمعى من الجرائم التنظيمية، كالتى ترتكب فى مجال الصحة، والبيئة والإسكان والعمل مما يجعل من هذه الجرائم العديـة وغير العمديـة التى تحدث محلا لتطبيق هذا النص الذى يستبعد ويندر تطبيقه فى القتل والسرقة والضرب والتزوير باعتبارهـا جرائم طبيعية.

الشرط الثاني: استحالة تفادى الغلط: lerreur doit etre inévitable ou

Cas de Force وهو الغلط الذى يقترب من حالة القوة القاهرة invincible mojeure والذى يوجد الجانى فيها فى ظروف لا تسمح له بتفادى الغلط، مهما بذل من جهذ سواء قام بالاستعلام بنفسه أو بالبحث والتحرى والاستقصاء من الغير

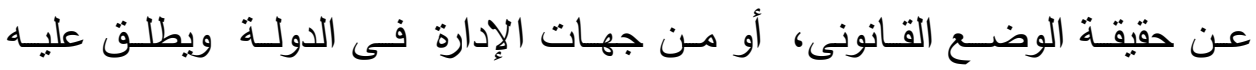
1,erreur de droit invincible

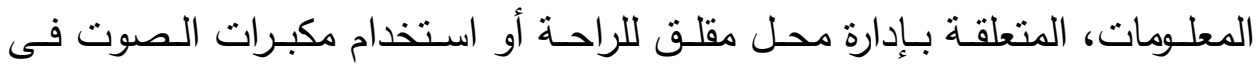
الدعايـة الانتخابيـة ويقع فى الغلط نتيجة المعلومـات التى أعطيت لـه من السلطة الإدارية المختصة أو أن نشاطره السلطة الإدارية المختصة، بتطبيق القانون الوقوع

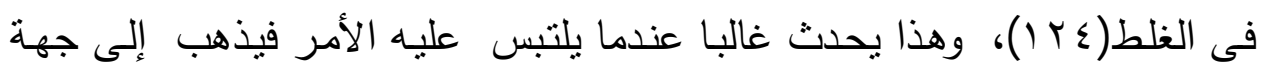

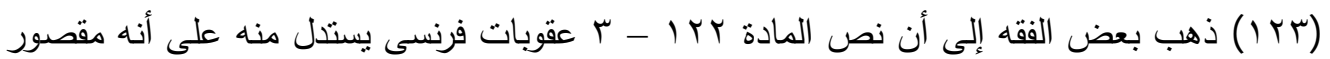

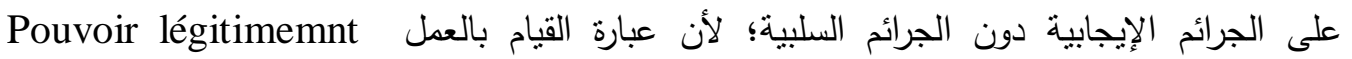
accomplir 1,acte

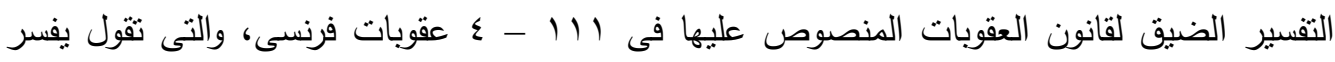
قانون العقوبات تفسيرا ضيقا La loi pénale est d’interpretation stricte لا تحظر التفسير عن لن

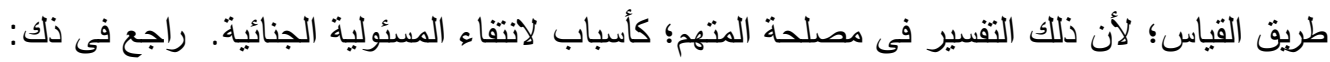

I T) : Beatrice chapleau - Mussau, questions sur 1,erreur de droit en reflexions sur la nouveau code penal sous le direction de christine lazerges 1995, P. 74 et 75; Crim 8 Fevrier 1966. No. 36 R.S.C. Voir les observations A 1, arret dans Puech (M.), Les Grands Arrêts de la jurisprudence criminelle T. I. legalite de la repression droit pénal général éd cujas 1976, PP. 427 :432.

ع r ا ) راجع فى ذللك : 
الإدارة المنـوط بهـا تطبيـق هـذا القـانون والتـى أحيانـا قـد تصدر مـذكرة تفسيرية بخصوصه مستفسرا عن مضمون النص الغـامض ومدى التزامسه بتطبيقه فى الزى

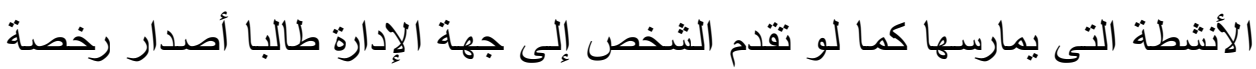
بإنشاء ورشـة لصناعة المعادن في منطقة سكنية فتجيبه جهة الإدارة إلى طلبه

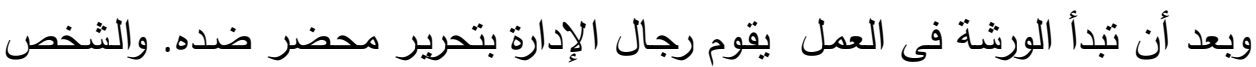
الذى يذهب إلى جهة الإدارة و الشرطة طالبا تصريح لإقامـة حفل عرس واستخدام مكبرات الصوت فتجيبه الثرطة وأيضا جهة الإدارة بأنه ليس فى حاجة إلى تصريح أو تعطيه تصريح شفهى ثم يفاجى بتحرير محضر ضده وكذلك الأمر بالنسبة للشخص الـذى يمـارس نـشاطا تجاريـا حديثا فيذهب إلى إدارة التهرب الضريبى لمعرفة قيمة الضرائب المطلوبـة فتجيبة إدارة التهرب الضريبى بأنه لديه إعفاء من إسن

حكم محكمة باريس الدائرة الثانية عشر والصادر فى /// / . . . ؟، حيث قضت "أن الاختلاف فى تفسير قاعدة القانون بواسطة المحترفين فى مجال القانون والخلاف قائم هنا بين دائرتين بمحكمة النقض - يشكل خطأ فى القانون لم يكن يستطيع المتهم أن يتجنبه" .

La divergence d interprétation de la règle de droit par les professionnels du droit - en l'espèce, divergence entre deux chambres de la Cour de cassation - constitue une erreur sur le droit qu’un prévenu n`est pas en mesure d’éviter. Ca Paris 12 Ch 9 Novembre 2000. Dr. Pen. 13 Année No. 5. 2001. P. 15. Viridiana Fernandez, lerreur sur le droit commentaire d`arrêt travaux dirigés de droit pénal, procédure pénale penologie dirigé par. Gabriel Roujou de boubée ellipses Edition 2001. P. 39; Crim 9 Octobre 1958 D. 1959 - 68 Voir les observations dans Pradel (J.) et Varinare (A.), Les grands arrêts du droit pénal général, 3 éme éd Dalloz, 2001 No. 45 PP. 561 :562; Robret (J. H.), Droit pénal général P.U.F. éditions 1998, PP. 294 :296.

$$
\text { وهذه أحكام لمحكمة النقض الفرنسية فى ظل القانون القديم والجديد : }
$$

Crim 26 juin 1956 Bull Crim No. 107 egalement Crim 26 Fevrier 1964 Bull Crim No 71; Crim 5 Mars 1997 Bull. Crim No 84.

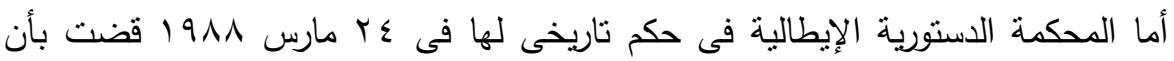
الغلط الذى لا يمكن تجنبه فى القانون ينفى الركن المعنوى للجريمة؛ لذلك قيل بأن ذلك يعتبر حكماً

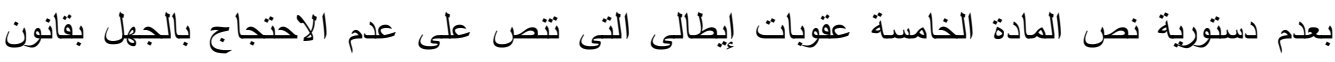
العقوبات 
الضرائب لمدة عامين من بدايـة النشاط ثم يفاجأ بأنـه متهم في قضية تهرب

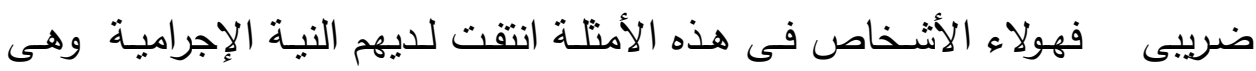

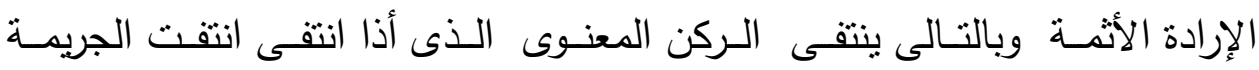

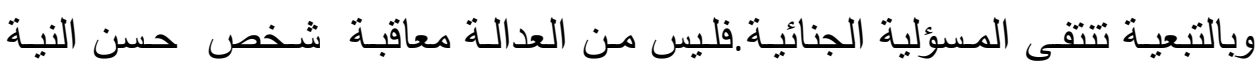
سعى جاهدا وبذل قصارى جهده لمعرفة الحكم الصحيح للقانون حتى يلتزم بـه فإذا هو يقع فى غلط حتمى شاركته فيه جهة الإدارة وانعدمت لديه النية الإجرامية ,وعلى ذلك إذا ثبـت أن الفاعل وقت اقترافه للسلوك الإجرامسى لـم يبـل كل مـافى وسـعه لمعرفة حكم القانون فى حالة استخدام مكبرات الصوت فإنه يكون مقصرا ولايعد

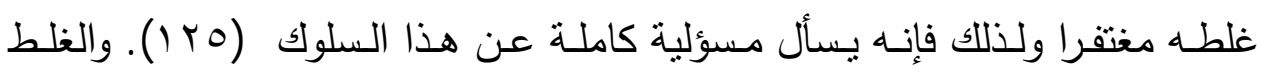
ليس قاصـرا على الاعتقـاد الخـاطىء بمشروعية الفعل الذى ارتكبـه الفاعل وإنمـا يشمل الجهل بخضوع هذا السلوك لنص تجريمى يعاقب عليه سواء كان جهلا كليا أو غلطا فى التفسير أو التأويل للنص العقابى (T M ا ) والغلط فى مضمون الحكم الجنائى لا يعتبر غلطا فى القانون، لأن الجانى باستطاعته التقدم بطلب لمصدر

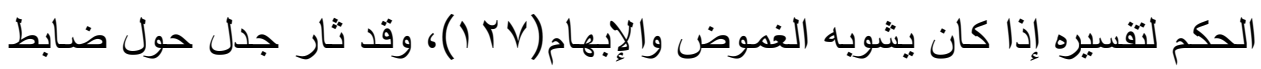
الغلط الذى يؤخذ به باعنباره نافيا للقصد الجنائى .

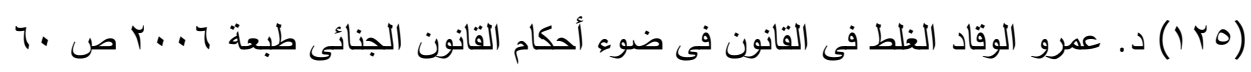
Stefani (G) Levasseur (G) bouloc(B) droit penal -general dalloz 2000361

- ( I rV)Crim 11 Octobre 1995. D. 1996. P. 469.

وتتلخص وقائع ذلك الحكم فى استحصال الزوجة على حكم بالبقاء فى منزل الزوجية دون الزوج

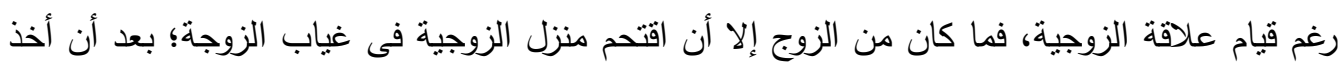

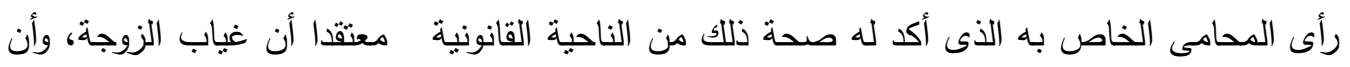

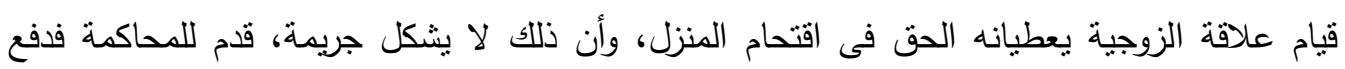

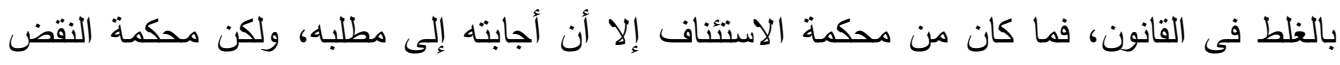

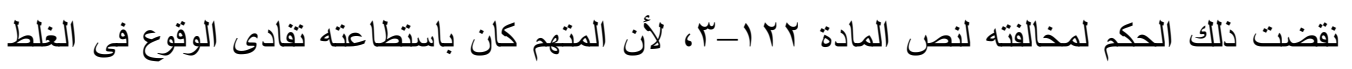


Appreciation in concreto فناك رأى بأخذ بالمعيار أو الضابط الشخصى الذى يتم تقديره بالنظر إلى اعتبارات متعلقة بشخص الجانى وقدراته( ب ( )، وهناك رأى بأى آخر يأخذ بالضابط الموضوعى Appreciation in abstracto، وهو معيار الرجل المعتاد إذا وجد فى نفس ظروف الجانى مع مراعاة المكان والزمان الذى أتى فيه الجانى

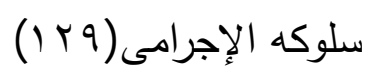

لكن المستقر عليه هو الأخذ بالمعيار المختلط الذى يأخذ فى الاعتبار الظروف

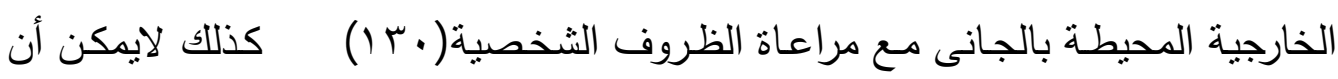

بتقديمه طلب تفسير Interpretation إلى القاضى الذى أصدر الحكم، أما وإنه لم يفعل ذلك فإن ذلك إهمال منه ينتفى معه شرط استحالة تفادى الغلط؛ لأن ذلك تقصير من المنهم I ^^ ) Marty (M.D.) et Christine lazerges, Apropas du Nouveau code pénale Francais R.D.P.C., 1997. P. 150.

i 9 ) Beatrice chapleau - Musseau, questions sur 1,erreur de droit, Op. Cit., P. 84.

( • Merle et Vitu إلى القول بمعيار أو ضابط موضوعى وآخر شخصى مختلفين، فالمعيار الموضوعى يقوم على أساس التفرقة ما بين الجرائم المتعلقة بالقانون

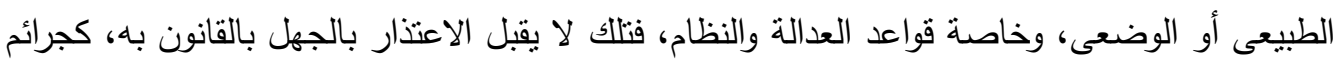

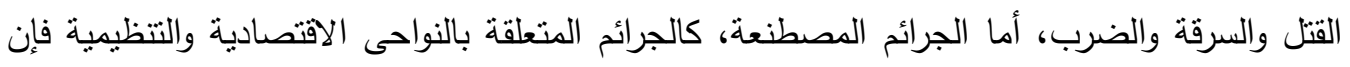

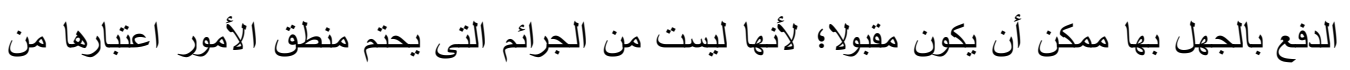

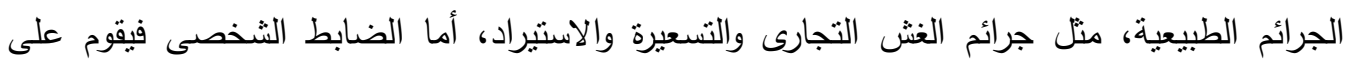

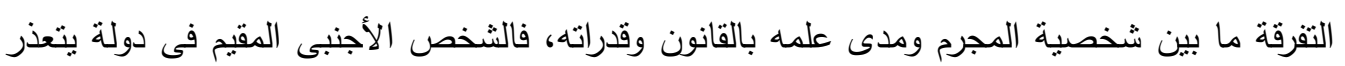

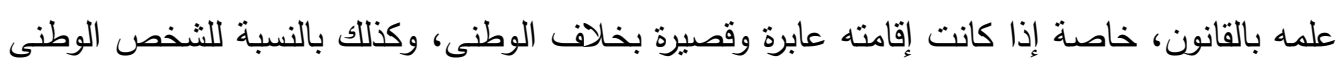
نفسه داخل الدولة إذا انتقل من إقليم أو مكان آخر فإنه يجهل القواعد التظيمية وانية والمحلية راجع: Merle et Vitu, Op. Cit., P. 686 A 688.

أما الفقيه دوندييه دى فاير فقد قال بمعيار آخر يقوم على أساس التفرقة ما بين القواعد

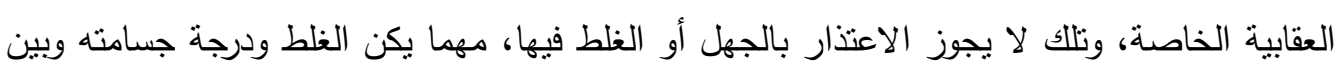

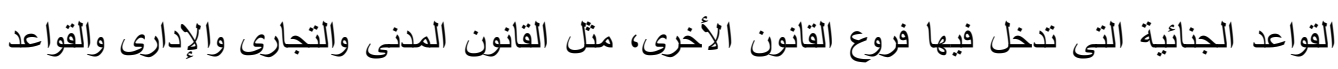

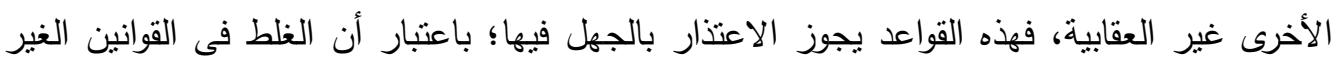
عقابية غلط فى الوقائع 
يتذرع المتهم بأن طبيعـة ممارسـة النشاط تقتضى صدور الضوضاء لأن جهة الإدارة ممثلة في البلديـة منوط بها إصـدار التعليمات التى تنظم كبفيـة ممارسـة هذه الأنشطة

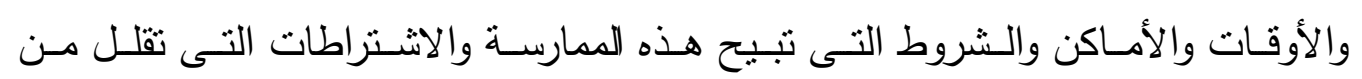

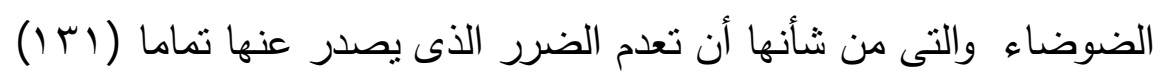
الشرط الثالث: وهو الحالة الذهنية والنفسية للجانى، وهو الاعتقاد بأن مـا أناه الجانى

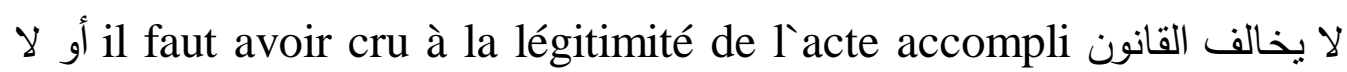

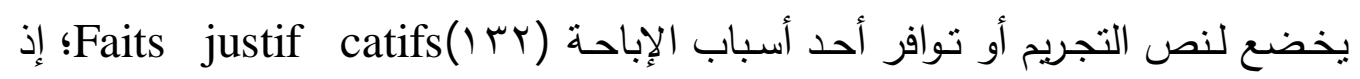

Donnedieu De Vabres (H.), Traité élémentaire de droit criminel 3 éme éd Paris, 1953, No. 139. Et Voir Viridiana (F.) l'erreur sur le droit commentaire d'arrêt travaux dirigés de droit penal procedure penologie dirigé par Gabriel Roujou de Boubée ellipses éd 2001. ., No. 10. P. 43

وراجع د. على محمود حمودة: الغلط فى القانون ومدى اعتباره مانعا من المسئولية الجنائية، دار

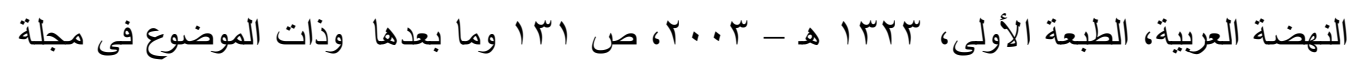

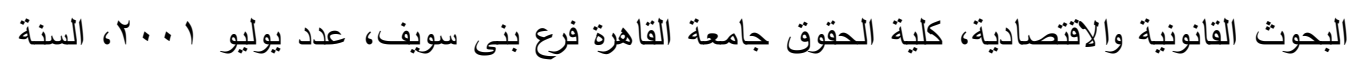

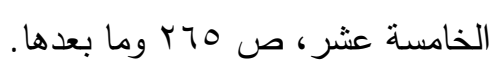

131) - CRIM 19 NOVEM 1985 B .C NO 36

(132) Cour de Reims I Avril 1994 Gaz - Pal - 1994-1-316.

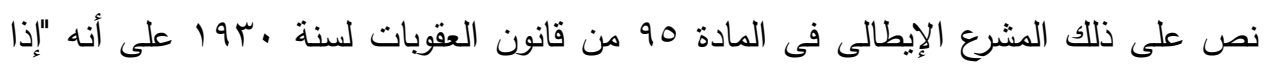

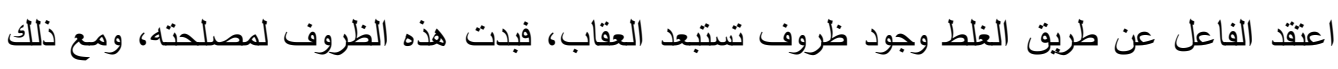

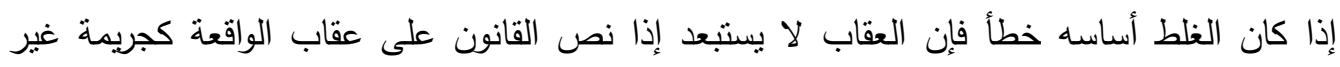

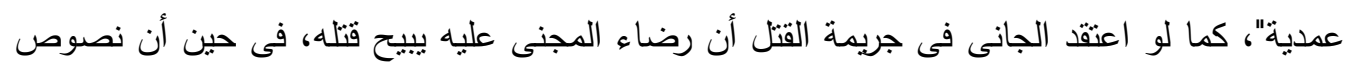

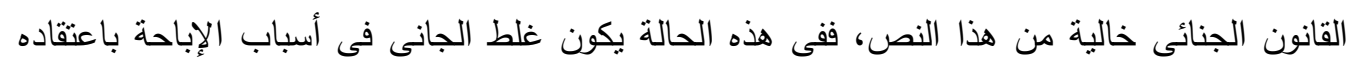

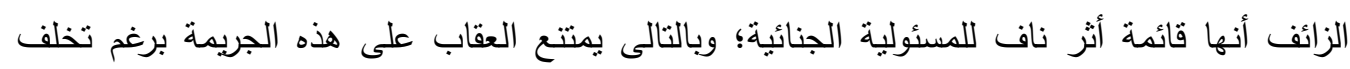

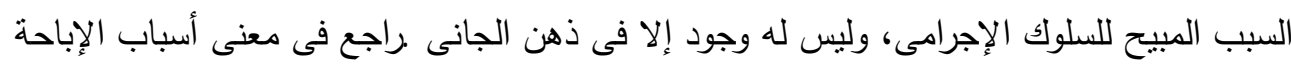

Ayache (A.B.), Dictionnairé de droit pénal général et procédure pénal ellipses edition 2001., P. 81.

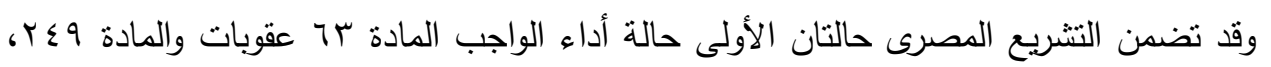

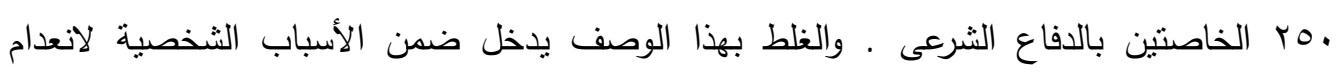

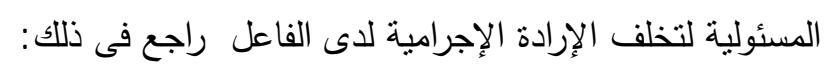


يجب أن يكون ذهن الجانى خاليا من الثك حول عدم مشروعية ما أتاه، فإذا ثار شك فى

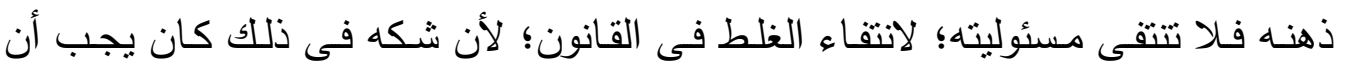
يدفعه إلى الاستعلام والتقصى عن حقيقة ما هو مقدم عليه من سلوك كما هو الحال فى لـى

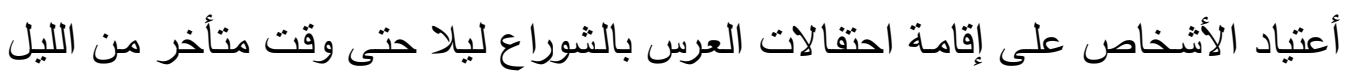

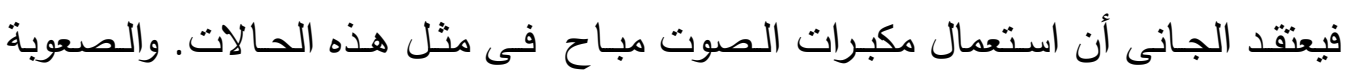
تكمن فى إقامة الدليل على نوافر الجهل أو الغلط لدى الفاعل فإذا ادعى شخص جهله بقانون حظر استعمال مكبرات الصوت وجب عليهه إقامـة الـليل على ذلك وبيـان الأسباب والظروف التى جعلته جاهلا والتى حالات دون العلم بالقانون كما لولم يتم

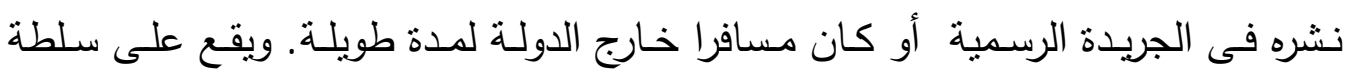
الإتهام إثبات علم الفاعل بالقانون كما لو سبق له أن كتب مقالا تعليقا على هذا القانون أو تحدث فى حلقة نقاشية عن الجوانب الإيجابية والسلبية لقانون حظر استعمال مكبرات

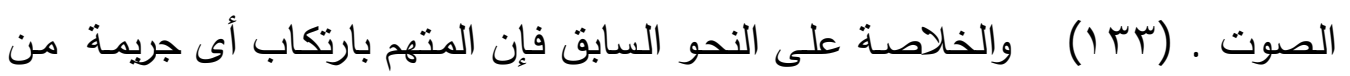

Stefani (G.), levasseur (G.) et Bouloc (B.), Droit pénal général, 16 éme éd dalloz 1997., No. 416. P. 322.

وراجع ذلك الخلاف الفقهى حول التكييف الصحيح لانتفاء المسئولية الجنائية فى هذه الحالة:

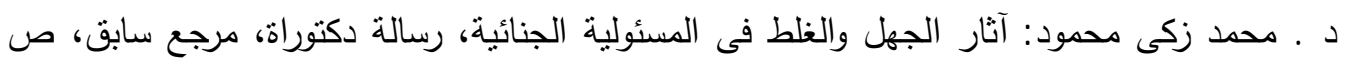

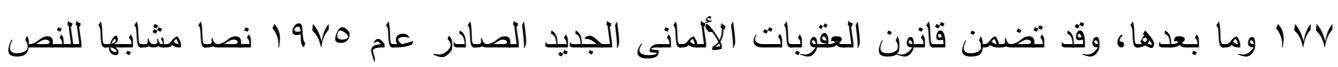
الفرنسى، هو نص المادة IV التى جعلت الغلط الذى لا يمكن تجنبه أو تفاديه فى القانون سببا لانتفاء

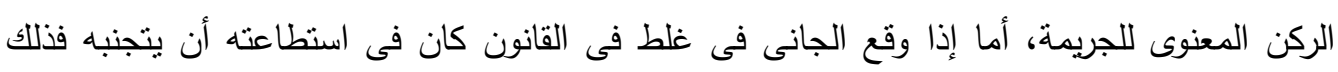

$$
\text { يخف المسئولية ولا يعدمها }
$$

(133 ) ذهب الفقيهان ميرل وفينى Merle et Vitu إلى القول بمعيار أو ضابط موضوعى وآخر شخصى مختلفين، فالمعيار الموضوعى يقوم على أساس التقرقة ما بين الجرائم المتعلقة بالقانون

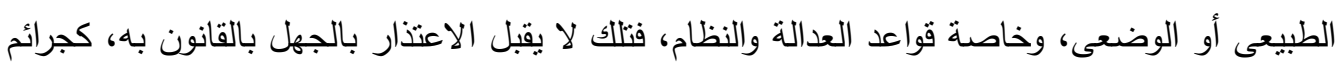

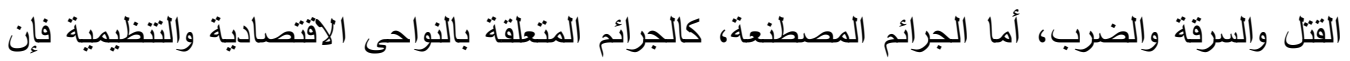

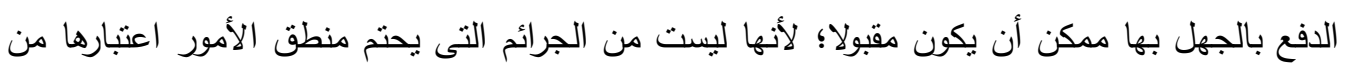

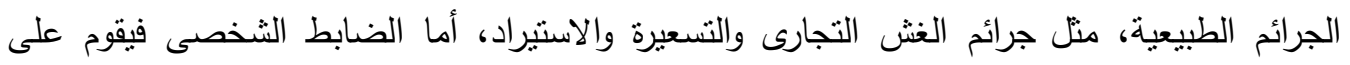

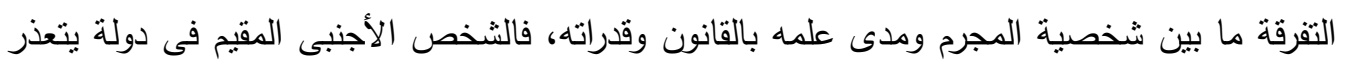


جـرائم التلـوث السمعى لـه أن يتمسك بالجهـل أو الغلـط فـى القـانون توصـلا إلى نفى

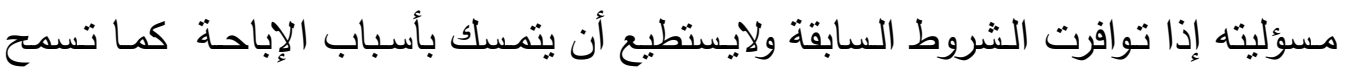
العادات والأعراف والتقاليد كما هو الحال فى حالات العيد القومى لمدينـة أو محافظـة أوحالـة الفوز فى البطـولات الدوليـة الرياضـية لبعض الأنديـة أو إطـلاق آلات التببيـه

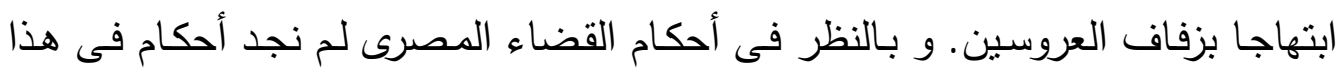
الثأن. ولكن القضاء الفرنسى ذهب إلى تطبيق القانون فى مثل هذه فلا يستطيع هرتكب

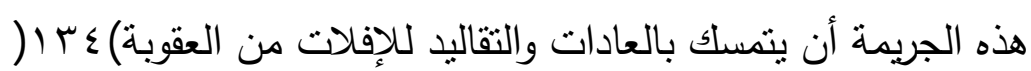

علمه بالقانون، خاصة إذا كانت إقامته عابرة وقصيرة بخلاف الوطنى، وكنلك بالنسبة للشخص الوطنى

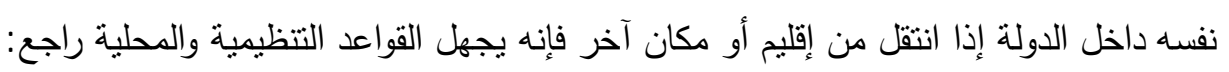
Merle et Vitu, Op. Cit., P. 686 A 688.

أما الفقيه دوندييه دى فاير فقد قال بمعيار آخر يقوم على أساس التقرقة ما بين القواعد العقابية الخاصة، وتلك لا يجوز الاعتذار بالجهل أو الغلط فيها، مهما يكن الغلط ودرجة جسامته وبين

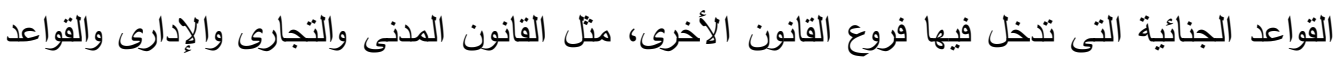
الأخرى غير العقابية، فهذه القواعد يجوز الاعتذار بالجهل فيها؛ باعتبار أن الغلط فى القوانين الغير الإنى عقابية غلط فى الوقائع

Donnedieu De Vabres (H.), Traité élémentaire de droit criminel 3 éme éd Paris, 1953, No. 139. Et Voir Viridiana (F.) l'erreur sur le droit commentaire d'arrêt travaux dirigés de droit penal procedure penologie dirigé par Gabriel Roujou de Boubée ellipses éd 2001. ., No. 10. P. 43

وراجع د. على محمود حمودة: الغلط فى القانون ومدى اعتباره مانعا من المسئولية الجنائية، دار

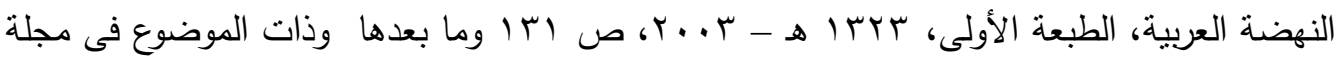

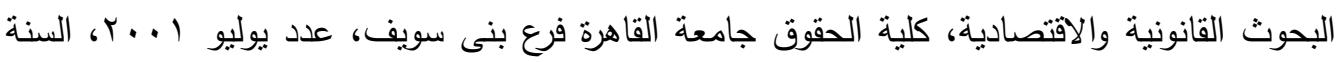
الخامسة عشر، ص ب T Y وما بعدها.

134) - crim 13 oct 1936 BC NO 344 . 


\section{الفصن الثانى}

\section{De la Volonte الإرادة}

الثق الثانى للقصد الجنائى هو الإرادة؛ حيث لا يوجد القصد الجنائى إلا بتوافر

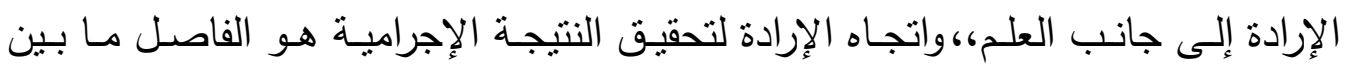

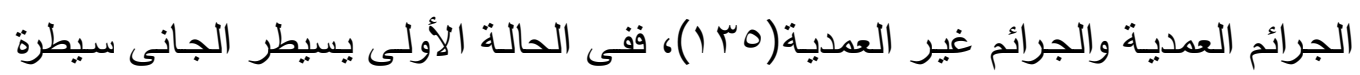

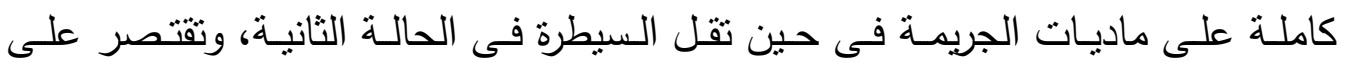
السلوك فقط( ب (1)، فالإرادة هى تعمد الفعل المادى أو الامتتاع، أمـا القصد فهو تعمد النتيجة المترتبة على ذلك الفعل أو الامتتاع.

؛ فقـى الجريمـة العمديـة تتخـــ الإرادة مـن النتيجـة هـدفا تـسعى إلـى تحقيقهـ،

ويقتضى ذلك بالتبعيـة تـوافر عنصرى القصد المباشـر ، وهمـا توقـع النتيجـة الإجراميـة

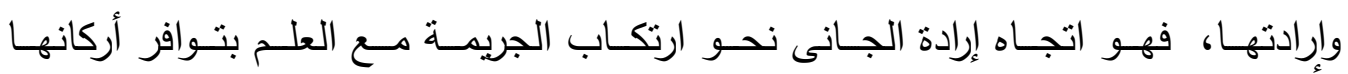

(135) راجع فى مدلول الإرادة عند الفقيه Garraud؛ حيث يرى أن للإرادة مدلولين : الأول هو الإرادة

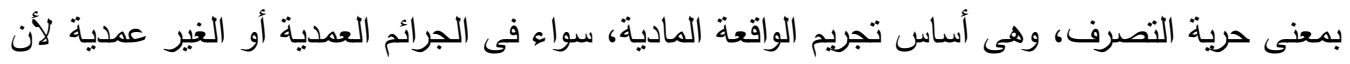

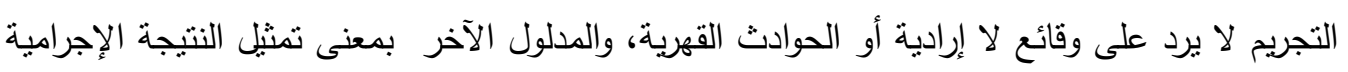

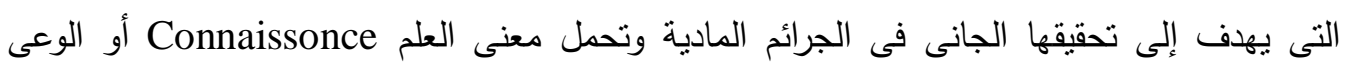
infraction بالنشاط الإجرامى المجرد من النتيجة المادية، كالجرائم الثكلية Conscience intention formelles criminelle

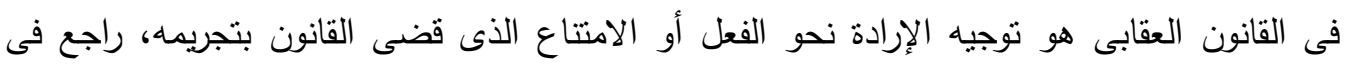

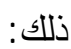

Garraud (A.), T. I. Op. Cit., No. 287. P. 571.

$$
\text { وراجع تعريف الإرادة د نبيل مدحت: الخطأ الغير عدى، مرجع سابق، ص بr . }
$$

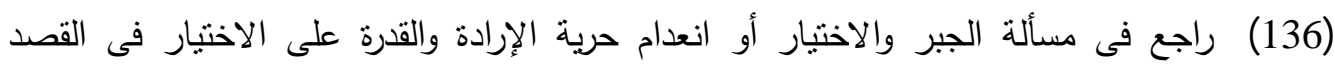

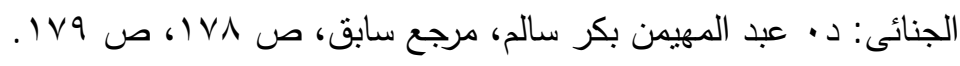


القانونية( I I )، أما فى الجريمة غير العدية نجد أن الهدف والغرض الذى اتجهت إليه

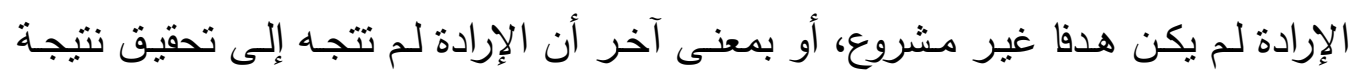

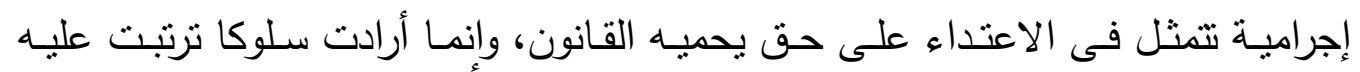
نتيجة غير مشروعة لم تتجه إليها . وللأرادة صورتين:

الصورة الأولى:وفيها تتجه إلى ماديات الفعل أو السلوك الإجرامى ولا تتجه إلى

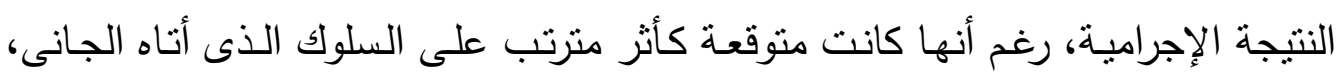

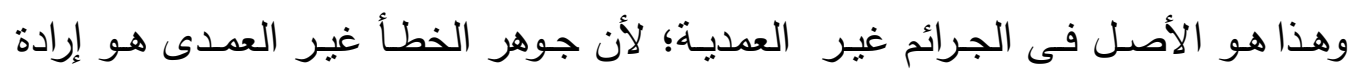
الجانى التى اتجهت للسلوك الإجرامسى الذى ترتبت عليه نتائج غير مشروعة، لم يتوقعها

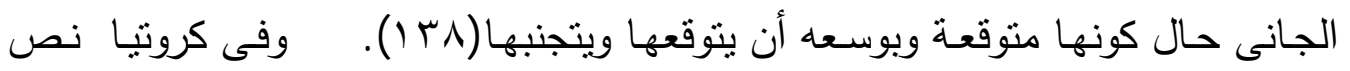

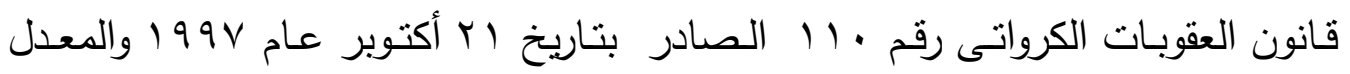
بالقانون رقم 111 والصادر فى 10 يوليو عام ب . .r على جريمة التلوث الضوضائى Endangering the تحت عنوان تعريض البيئة لخطر الضوضاء لئس

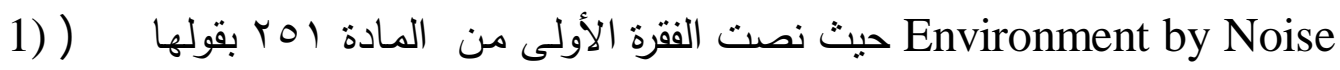
يعاقب بغرامـة أو بالسجن لمدة لا تزيد عن ثناث سنوات كل من يصدر ضوضـاء من من

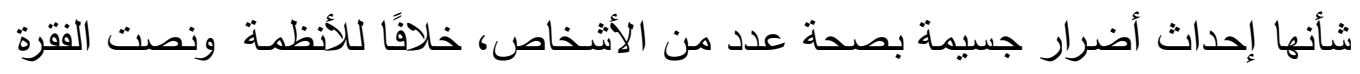
الثانية على (2) كل من يرتكب الجريمـة المشار إليها في الفقرة ا من هذه المادة

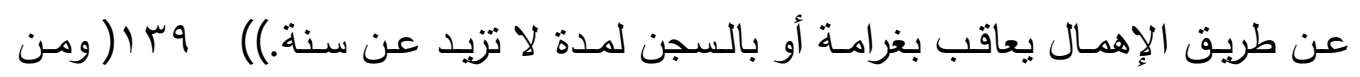

(137) درؤوف عبيد: مبادئ القسم العام من التشريع العقابى، الطبعة الرابعة، دار الفكر العربى،

$$
\text { (9V9 }
$$

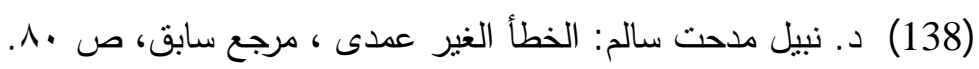

( 139 ) Article 251

1)) Whoever, contrary to regulations, makes noise which is apt to cause substantial damage to the health of a number of persons shall be punished by a fine or by imprisonment not exceeding three years. 
استقراء هذا يتضح أن جريمة الضوضاء العمدية تكون مشددة العقوبة بخلاف الجريمة

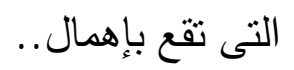

ويترتب على ذلك أن الإرادة إذا اتجهت إلى السلوك فقط فى الجرائم الشكلية أو

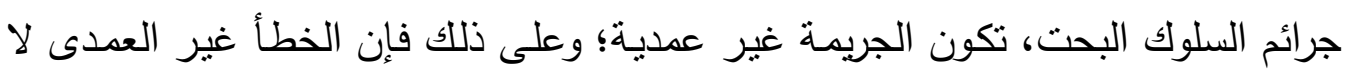

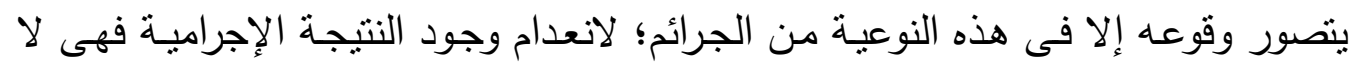

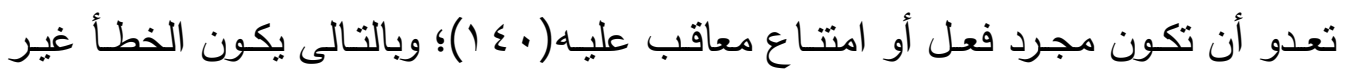

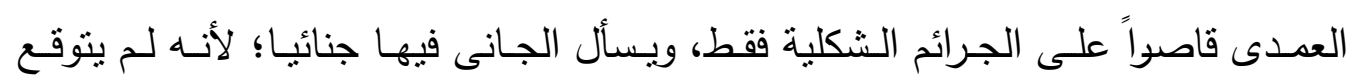

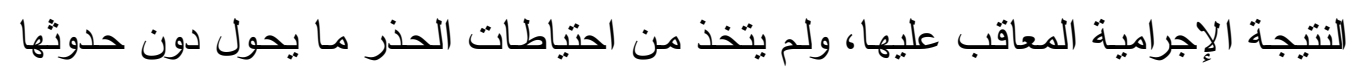
N,ont pas pris les mesures permettant d,eviter dommage سلوك الجانى متسما بالرعونة أو الطيش impru dence Maladresse أو عدم

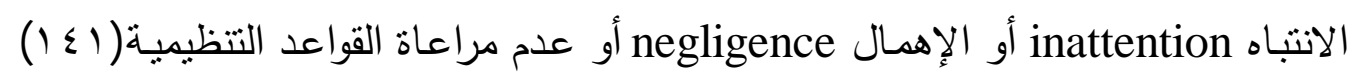
defaut de precaution أو عدم الاحتياط inobservotion des reglemenits واتسام السلوك بإحدى الصور السابقة يجعل النتيجة الإجرامية متوقعه الحدوث،

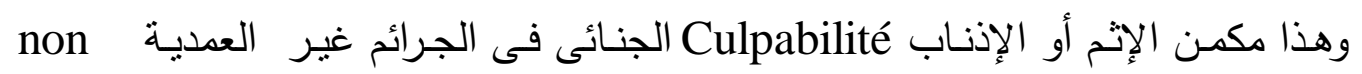
antentionnolle infractions

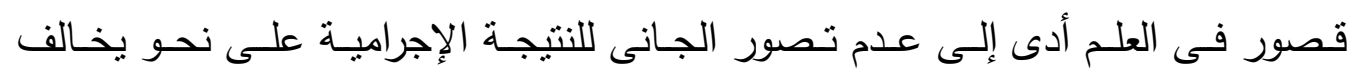
الحقيقة، فحدثت نتيجة أخرى غير مشروعة لم يتصورها الجانى، ولم يتوقعها حال كونها متوقعة، ولم تتجه إليها إرادته؛ لذلك فإن الغلط قد طرأ على العلاقة ما بين الإرادة والعلم

r) Whoever commits the criminal offense referred to in paragraph 1 of this Article by negligence shall be punished by a fine or by imprisonment not exceeding one year

(140) راجع فى ذلك: د . على راثد: القانون الجنائى، المدخل وأصول النظرية، الطبعة الثانية، ، دار

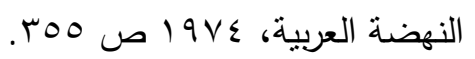

(141) نم استبدال هذه العبارة فى قانون العقوبات الفرنسى الجديد بعبارة مخالفة التزام الأمان والحيطة المفروض بواسطة القانون أو القواعد التتظيمية. Manquement a une obligation de securité imposée par la loi ou les réglement. 
فأدى إلى حدوث نتيجـة غير متوقعـة للجانى إلا أنـهـ كان بمكنه توقعها، والحيلولـة دون حدوثها إذا بذل العناية اللازمة، مثنال ذلك المشاجرات التى ينجم عنها استخدام الأسلحة الناريـة أو الأفـراح التىى يطلـق فيهـا الألعـاب الناريـة والتـى تتـسبب فـى فـزع وازعـاج

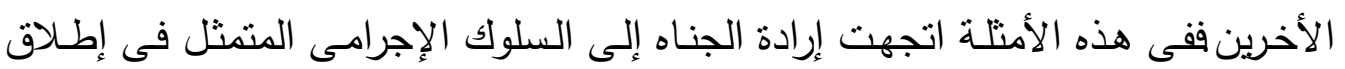
النار من أجل الابتهاج أو بث الرعب والفزع فى نفس الطرف الثانى الذى يتشاجر معه.

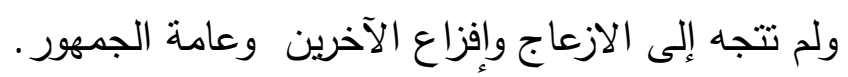
الصورة الثانية: هى أن الإرادة تتجه إلى الفعل والنتيجة الإجرامية :

واتجـاه الإرادة إلى النتيجـة الإجراميــة هـو صـورة الإرادة الإجراميـة فـى الجـرائم العدية ذات النتائج المادية، وهى الصورة الغالبة للجرائم كالقتل والضرب والسرقة وخيانة الأمانة والإزعاج والتوتز والقلق والإضرار بالأخرين.

حيث تتألف الجريمـة مـن ركنين : همـا الواقعـة الماديـة (وهـى الحالـة الخارجيـة) كركن ؤل وتشمل السلوك المـادى الإجـرامى الدافع إلى النتيجـة، ثم النتيجـة الإجراميـة المترتبة على السلوك الإجرامى، ثم علاقة السبيية ما بين السلوك والنتيجة، والركن الثانى:

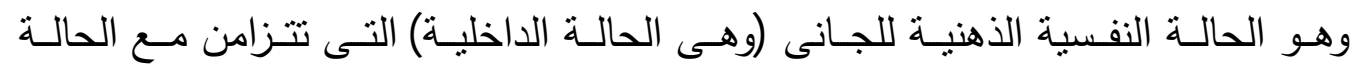

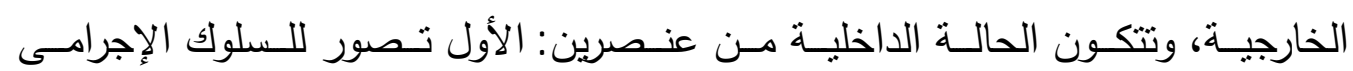
مصحوب بإرادة متجهـة إليه، والثانى تصور للنتيجـة الإجراميـة مصحوب بـإرادة متجهة الإنة

(142) المقصود بالنتيجة الإجرامية هنا هى النتيجة بالمدلول المادى، أى الأثز المادى المترتب على المى السلوك الإجرامى الذى قارفه الجانى، ويعاقب عليه القانون، وليس النتيجة بالمدلول القانونى الذئى يتمثل

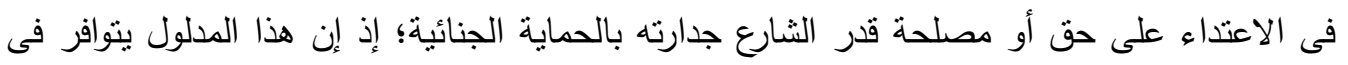
جميع الجرائم بلا استثاء (هادية وشكلية عمدية وغير عمدية جرائم خطر وجرائم ضرر ) · لمأل 
لتحقيقها (T乏 ( )،ومثنال ذلك استخدام مكبرات الصوت وإدارة آلات معينـة تصدر أصوات مرتفعة دون تصربح

\section{الفرع الثانى}

\section{الخطأ غير العمدى فى جر ائه التلوث السمى}

الخطأ غير العمدى يقوم على عنصرين الأول: هو العنصر المادى المتمثل فى عدم

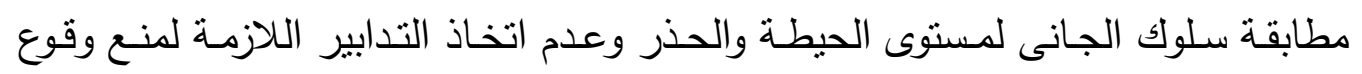

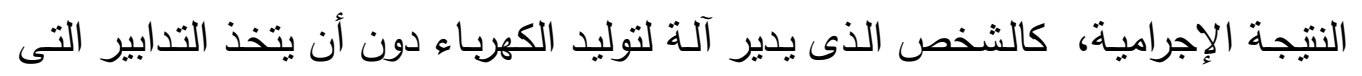

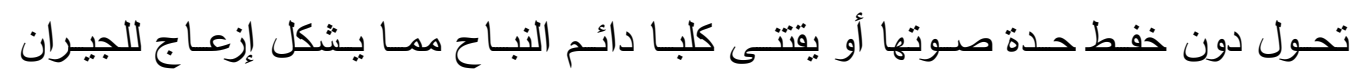
والمحيطين به.

والثانى : هـو العلاقـة النفسية بـين إرادة الجـانى والنتيجـة الإجراميـة. وهـذان العنصران يجمعهما تعريف "مضمونه هو المسلك الذهنى للجانى الذى يؤدى إلى نتائج إجراميـة لم يردها، وكان بوسعه أن يتوقها، وتوقع الفاعل للنتيجة الإجرامية، وعدم بذله العناية الواجبة لهونية

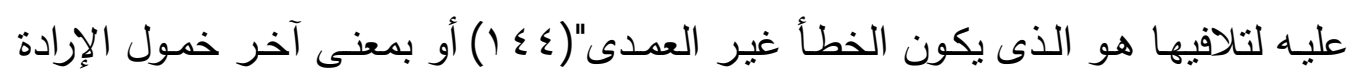
عن توقع النتيجة غير المشروعة مـع قدرتها على توقعها. ونتنكلم عن عناصـر الخطأ العمدى فى جرائم التلوث السمعى فى غصنين على النحوالتالى:

(143) Merle (A.) et Vitu (A.), Traité de droit criminal, 5 eme ed Gujas 1984 T. I No. 57. P. 105. 106, 107, 108, et Griffon.; De l’intention en matiere pénal, thése Paris, 1991, P. 106.

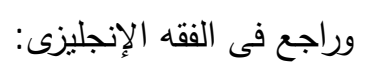

Alan Reed and Peter Seago, Criminal Law London Sweet Maxwell, 1999, PP.81:82; Marianne Giles, Criminal law, Fourth edition 1996, PP. 18:19.

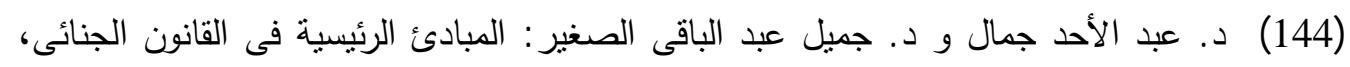

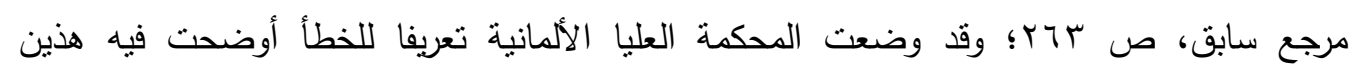

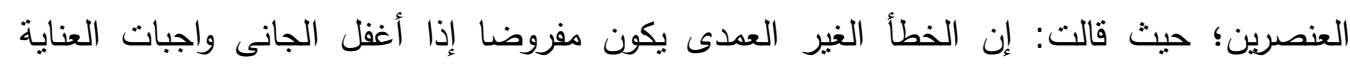

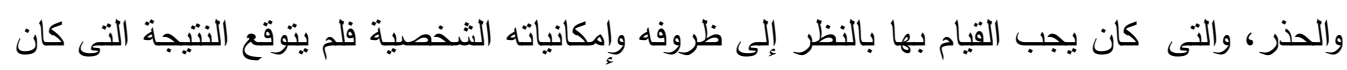

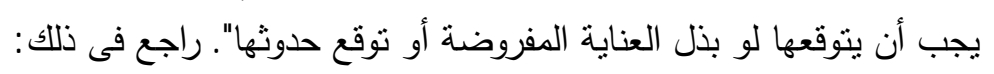
Roux (J.A.), Cours de droit criminel Français T. I. 1927. P. 150. 


\section{الفصن الأول}

\section{السلوك المخالف لواجبات الحيطة والحذر}

وتقتضى المصلحة العامة إقامة التوازن بين مصالح الأفراد فى ممارسة الأنشطة

التى قد يتولد عنها ضرر وحق المجتمع فى عدم إلحاق أى ضرر بحقوق الآخرين من جراء هذه الأنشطة التى يجب ممارستها بمراعاة واجبات الحيطة والحذر ، والتى هى عبارة عن سلوك يأمر المشرع بإتيانه، ويكون صـالحا لمنع وقوع النتيجة الإجرامية كعدم القيام بمنع ضوضـاء صـادرة عن آلة أو عدم وضـع الكلاب فى مكان يحول تضرر الجيران من نباحهم، وذلك يقتضى بيان مصدر واجبات الحيطة والحذر التى يخالفها الجانى على

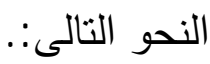

مصادر قواعد الحيطة والحذر تتقسم إلى مصادر عامـة التى تتمثل فى قواعد

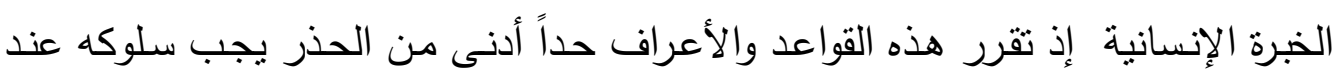
ممارسة نشاط معين (0 ؛ ()، والخطأ الناشئ عن مخالفة هذه القواعد يسمى بالخطأ العام كعدم تشغيل الموسيقى ليلا بصوت مرتفع، وذلك يقتضى من الشخص أن يسلك سلوك

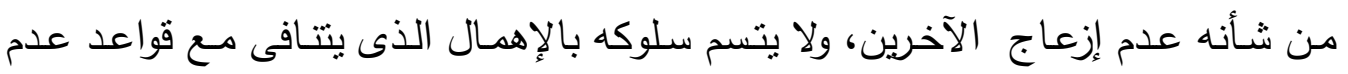
الإضـرار بـالآخرين، فالشخص الذى ينرك كلبا فى الشرفة ليلا مستمرا فى النباح كلما شـاهد شخص يمـر أمامـه بطريقة مـن شـأنها إصـابتهم بـالتوتر والإزعاج يعتبر مخالفاً

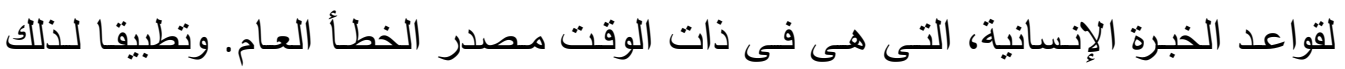
تضمت الفقرة الثانية من المادة rV9 عقوبات برتغالى النص على دلى أنه إذا كان السلوك المشار إليه في الفقرة الأولى يتم تتفيذه عن طريق الإهمال، فيحكم على الوكيل بالسجن لمدة تصل إلى سنة واحدة أوالغرامة.

ونصت المادة Oبr عقوبات ألمانى فى الفقرة الثانية التالثة على () أي شخص، أثناء تشغيل منشأة، ولا سيما مصنع أو آلة، متسببا فى انتهاك للواجبات المنصوص عليها في (145) د ـ محمود نجيب حسنى: الخطأ الغير عمدى، بحث سابق الإشارة إليه، ص • (0؛ ود . فوزية

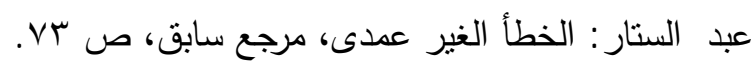


القانون الإداري والتي تعمل على الحماية من الضوضاء أو الاهتزازات أو الإشعاع غير

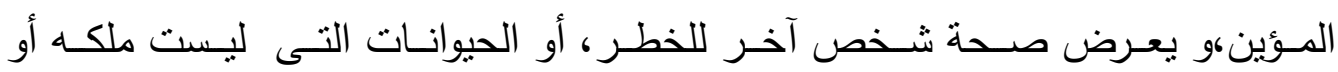

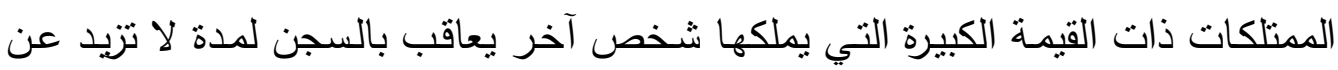
خمس سنوات أو غرامة مالية

. (3) إذا تصرف الجانى بإهمال فالعقوبة تكون - أولا. في الحالات المنصوص

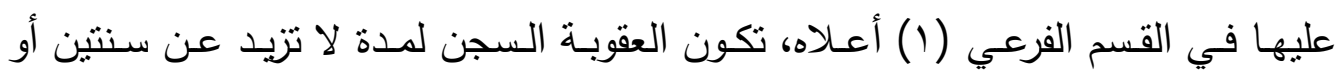
غرامة مالية ؛ ثانيا في الحالات المنصوص عليها في الفقرة الفرعية (r) أعلاه، تكون

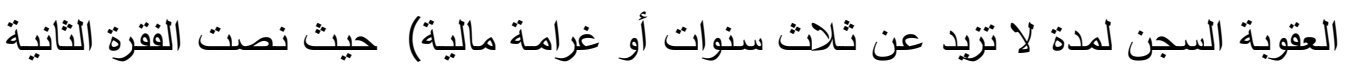

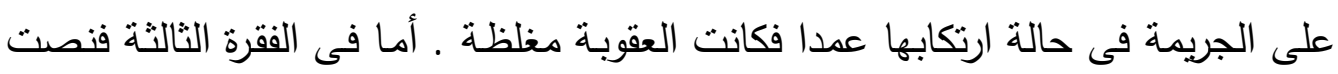
على عقوبة مخففة فى الخطأ غير العدىى وهو الأهمال.

ونحن نرى كذللك أن المهن التى لم ينظم المشرع ممارستها بقانون أو بقواعد

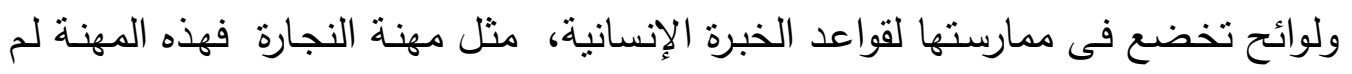
ينظمها المشرع بقانون خاص أو قواعد خاصة، ولكن تحكمها قواعد الخبرة الإنسانية التى تقتضى ألا يسبب النجار ضرراً، للأخرين بسبب الأصوات التى تصاحب تشغيل الالات

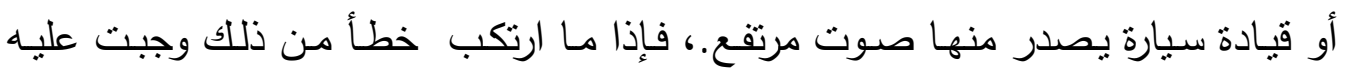

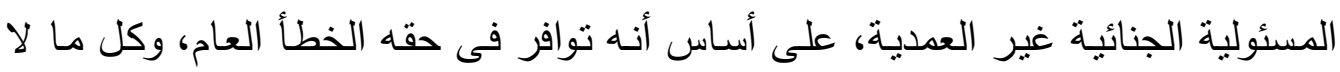
يتتاوله القانون بالتتظيم يدخل فى نطاق قواعد الخبرة العامة واعتبارات الملاعمة وبمفهوم

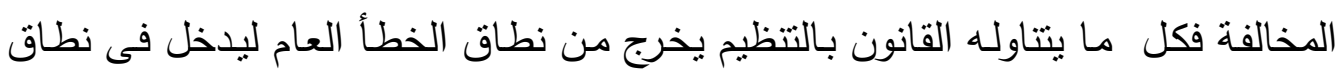

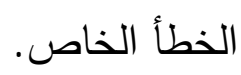

والمصدر الثانى هو القوانين واللوائح والقرارات التى تنظم مهنـاً معينة، ومخالفة هذا المصدر يرتب مـا يسمى بالخطأ الخـاص، وتلك الحسالة التى يتدخل فيها المشرع

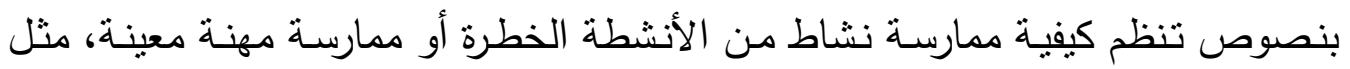


القوانين واللوائح والقرارات المتعلقة بقيادة السيارات و بـالمرور (7 ( ) )، وكذلك المنظمـة

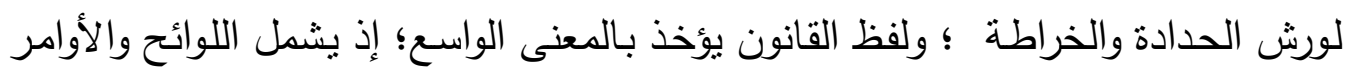
والتعليمات الإدارية فى كل صورها؛ وجميع المهن المنظمة بقوانين ..

\section{الفصن الثانى}

\section{العلاقة النفسية بين الإرادة والنتيجة الإجرامية}

لا عقاب على الخطأ غير العمدى فى حد ذاته، بل يشترط أن يترتب على ذلك

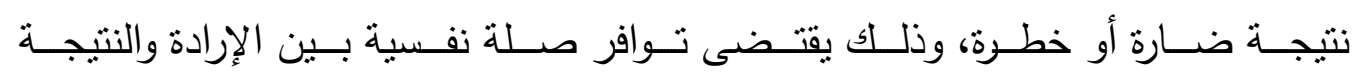

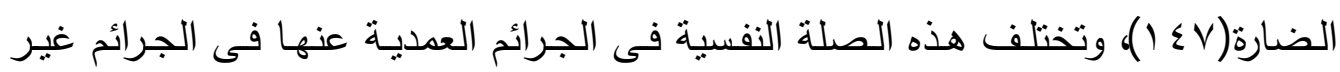

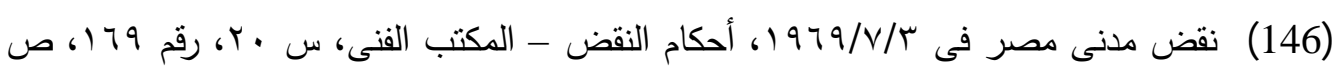
§ 9 ـ ا، وقد جاء بهذا الحكم أن أساس مسئولية الطبيب هي المسئولية التقصيرية وليست العقدية. (147) Nigel Foster and Satish sule, German legal system and laws, third edition, 2002, PP. 32:321.

خلاف ذلك برى د. أحمد فتحى سرور : أن العقاب فى الخطأ الغير عمدى علته لا تكمن فى النشاط

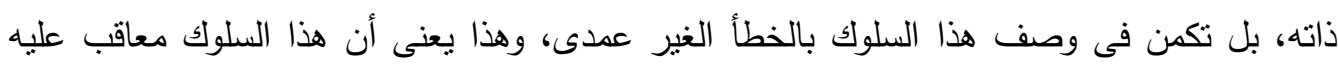
بغض النظر عن حدوث نتيجة إجرامية.

والباحث يرى أنه فى حالة تخلف حدوث النتيجة، سواء الضارة أو الخطرة يكون معيار الحكم على السلوك بكونه خطأ أو غير خطأ صعب للغاية، لأن السلوك فى الخطأ الغير عمدى يكون سلوكاً مشروعاً تتجه فيه إرادة الجانى إلى نتيجة مشروعة ولكن تحدث نتيجة فيله غير مشروعة لم تتجه إليها إرادة

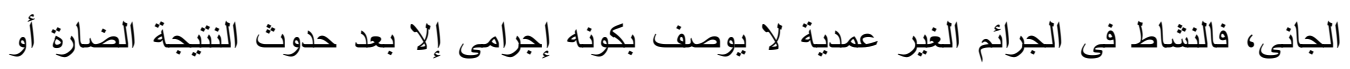
Vidal et Magnol, Op. Cit., P. 176.

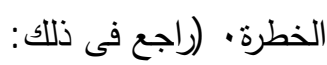

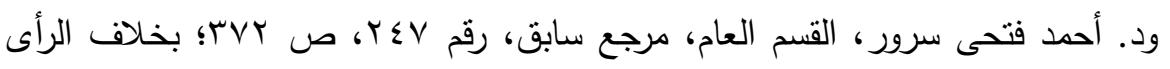

الذى نتقق معه:

Bayer (V.), l'infractions non intentionnelles cours de doctaret le Caire, 1963. P. 38.

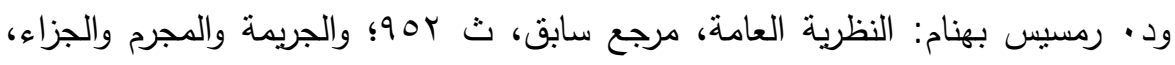

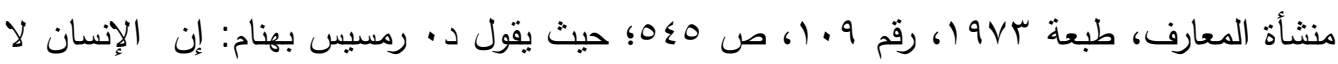
يستحق عقابا على إهمالا إلا حيث يكون الأمر الناشئ عن هذا الإهمال إخلالا لاحقا بمال من الأموال 
العمدية؛ ولأن الخطأ يختلف عن العمد le faute differe du dol ففى حالة العدد en cas de dol la Fait et 1,effet sont يكون كلاً من الفعل والنتيجة إراديا volontairs et voulus

أما الوضع فى الجرائم غير العمدية فإن السلوك يكون إراديا، بخلاف النتيجة فلا en cas de faute la cause est volontaire et voulue mais تتجه إليها الإرادة non 1,effet

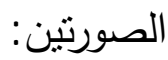

الصورة الأولى:وفيها لا يتوقع الجانى النتيجة الإجرامية، ولا تتجها إليها إرادته،

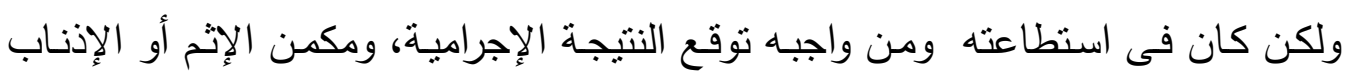

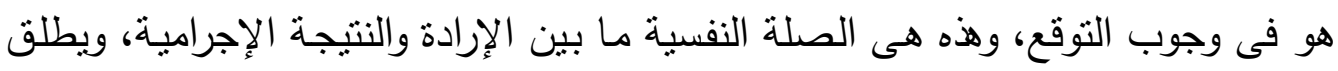

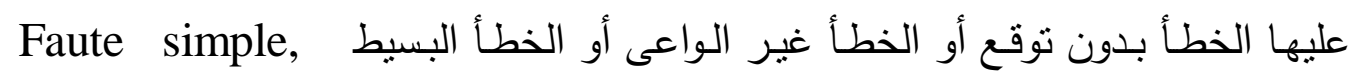
كمن يـدير حفـلات الموسيقى الصاخبة أو يترك كلبا بشرفة

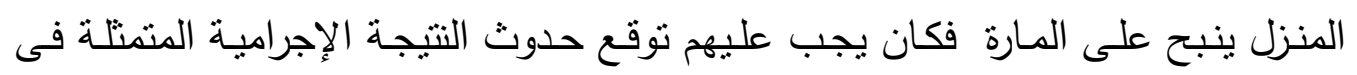

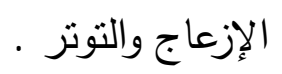

بالغ فى صلته بالكيان الاجتماعى درجة خاصة من الأهمية تبرر فى نظر القانون أن يكون المساس بـ

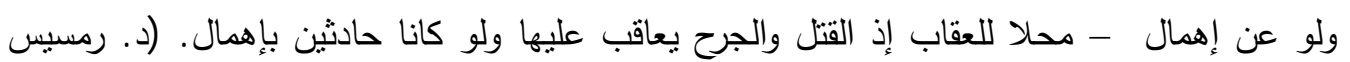
بهنام، المراجع السابقة) · باسنثناء جريمة الإتلاف الغير العدىى فلا عقاب عليها إلا إذا كانت وسيلة الإتلاف هى النار عمدية كانت أو غير عمدية) ويتفق معه فى الرأى Vidal et mangnol

La répression de la Faute ne dépend que du résultat matériel de 1,effet de 1,acte la faute qui par un hasard heureux n,Apas Causé de mal doit être impunie.

فقانون العقوبات الأردنى لم يعاقب على كل نتيجة تبنى على خطأ، وإنما تخير نتائج معينة

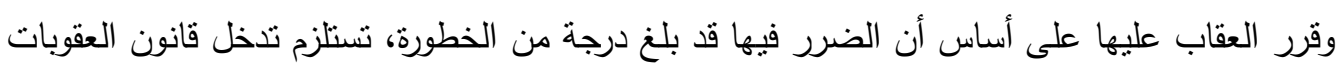

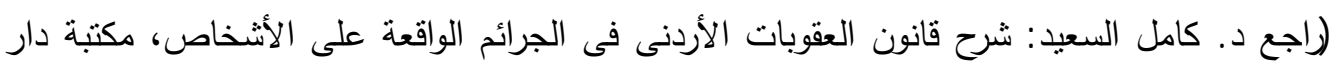

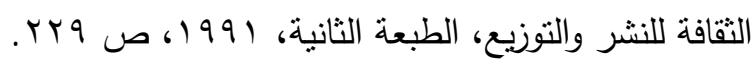


Faute consciente والصورة الثانية هى: الخطأ مع التوقع أو الخطأ الواعى وفيها يتوقع الجانى النتيجة الإجرامية، فلم يتخذ القدر الكافى من الحيطة والحذر، ولكنه أقدم على السلوك اعتمادا على قدراته ومهارته فى الحيلولة دون حدوثها، كمن يقدم على لهى

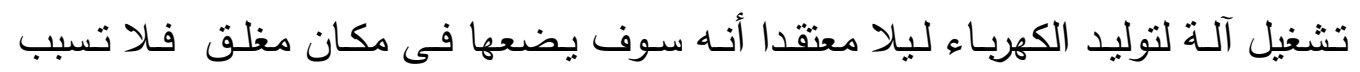
إزعاج للأخرين فيفشل فى السيطرة والتحكم فى الصوت فيتسبب في إزعاج وقلتق

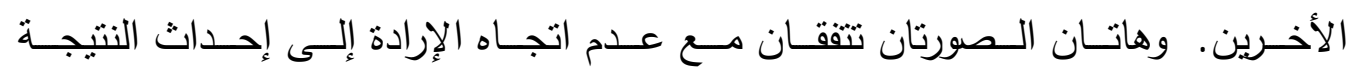
الإجرامية(1 § ()، وفيما يلى بيان ذلك بتفصيل أوفى :

Faute simple, Faute incansciente 1

تلك الحالة التى لا يتوقع الجانى نتيجة سلوكه الخاطئ، ولا تتجه إليها إرادته، فى حين

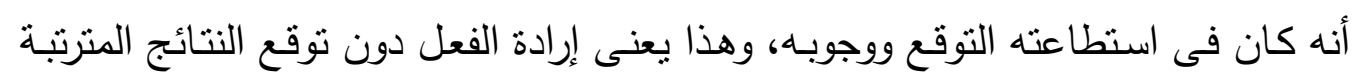

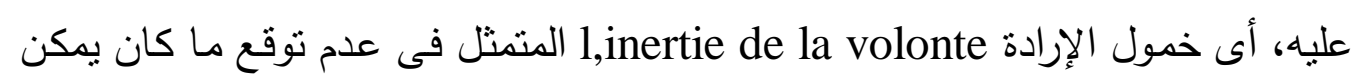
توقعـه(9 \ ()، فالعلاقـة النفسية تقوم على أسـاس خمول إرادة الجـانى عن نوقع النتيجـة الإجرامية، وكان فى استطاعته، وكان واجبا عليه أن يتوقعها: حيث إن النتيجة الإجرامية بطبيعتها ممكنة التوقع، وفى قدرة الجانى الحيلولة دون وقوعها إذا ما كان حدوثها متفقا

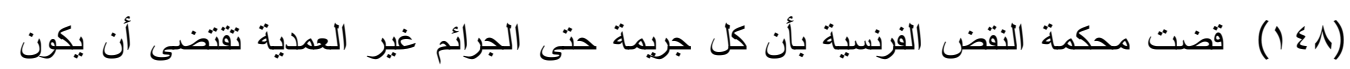
الجانى قد ارتكب فعله بإرادة وادراك

Toute infraction meme non intentionnelle, suppose en effet qu son auter ait agi avec intelligence et volonte (Crim. 13 Decembré 1956. D. 1957. P. 349.

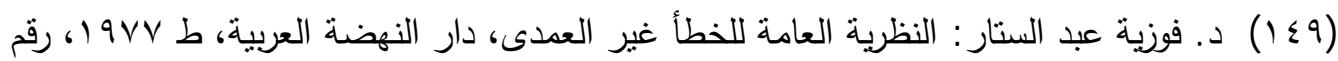

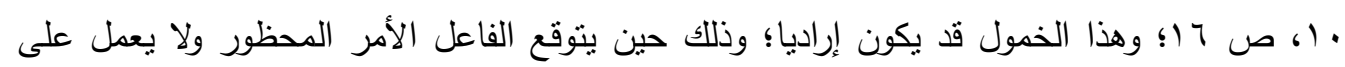

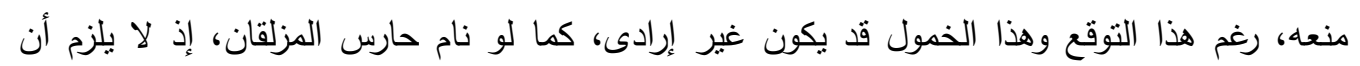

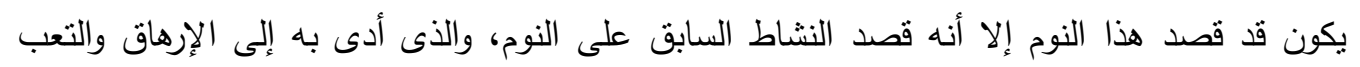

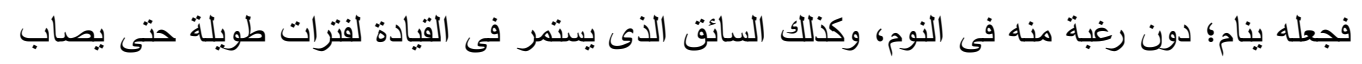

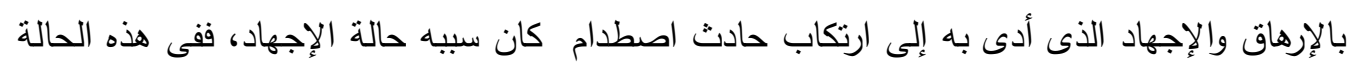

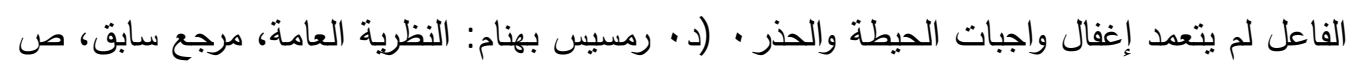
9 9 9 ) • وهذه الحالة الأخيرة هى التى ينطبق عليها الخطأ البسيط فى حين الأولى خطأ واع. 
مـع السير العادى للأكور ، كحال الشخص الذى يترك كلبا ينبح طوال الليل فى شرفة

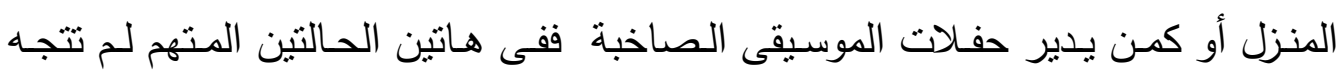

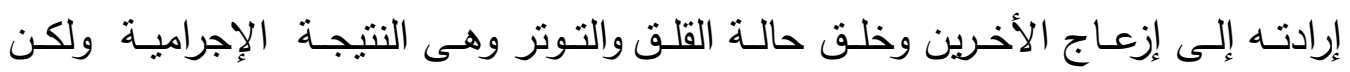

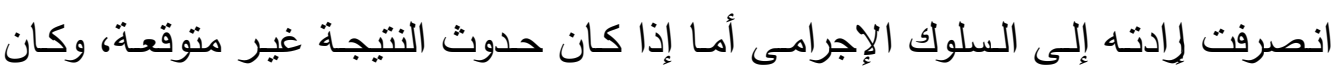
حدوثها بسبب تداخل عوامل شاذة وغير مألوفة ولا تقع عادة فى النادر فلا مسئولية على الإنى

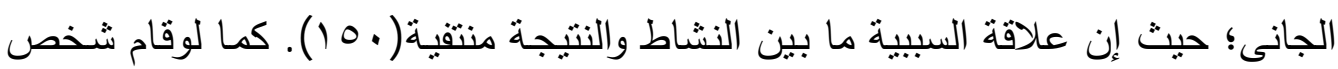
بعمليات استفزار للكلب عبر الشرفة جعله ينبح طوال الليل فأزعج جميع السكان بالمبانى إنى

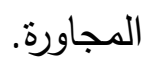

Faute consciente والحالة الثانية أو الصورة الثانية هى صورة الخطأ الواعى، وفى هذه الحالة يتوقع الجانى نتيجة سلوكه الخاطئ ولكن لا تتجـه إرادته إليها، ولم يثثه هذا التوقع عن سلوكه الخاطئ اعتمادا منه على مهارته وقدراته فى الحيلولة دون حدوث النتيجة الإجرامية، فهو يأمل فى عدم حدوثها رغم أنه لم يتخذ القدر الكافى من الحيطة

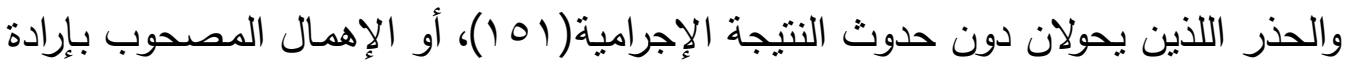
إغفال السلوك الواجب إتيانـه المقترن بتوقع الفاعل للحادث الضار ، وهو الذى يسمى الذهى بالإهمال الواعى( I r ) كعدم وضع الكلب المستمر فى النباح فى مكان لايسبب إزعاج

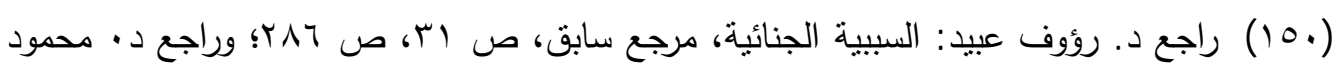

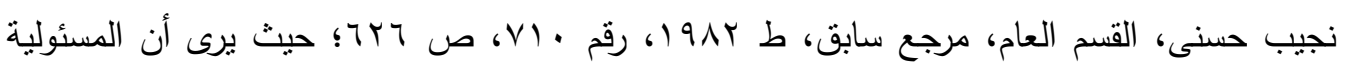

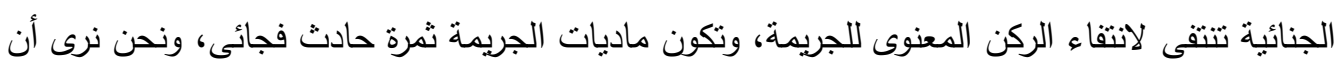

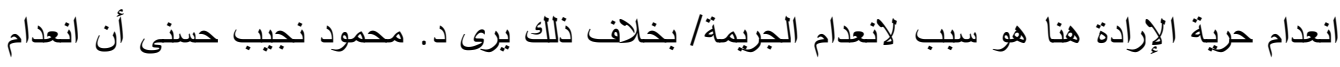

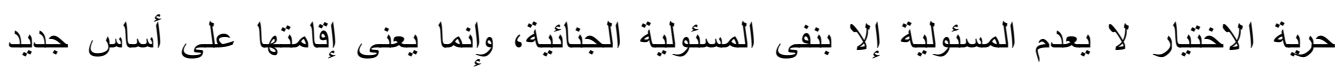

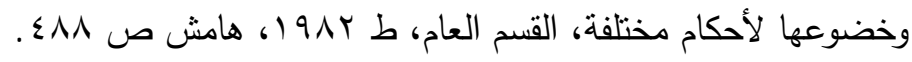

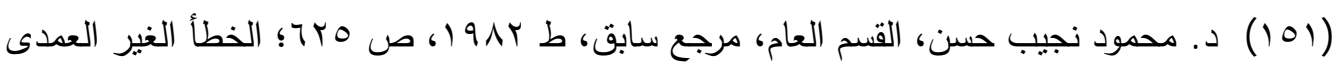

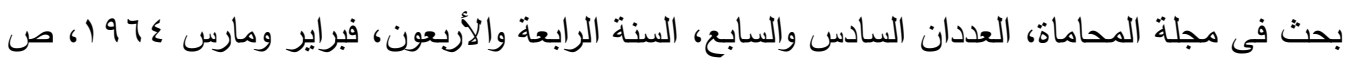

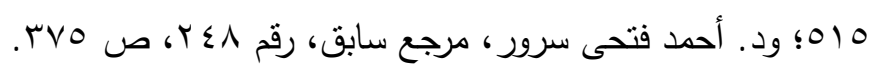

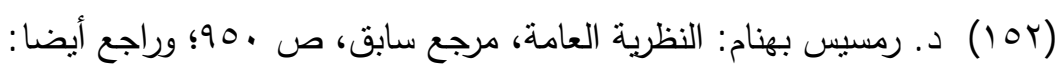
Ian loveland, Frontiers of criminalits, sweet maxwell 1995. P. 122. 


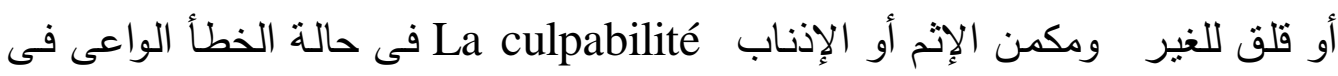
عدم القيام بعمل مـن أجل تجنب النتيجـة الضارة التى توقعها الفاعل، أو بمعنى آخر الإبـ

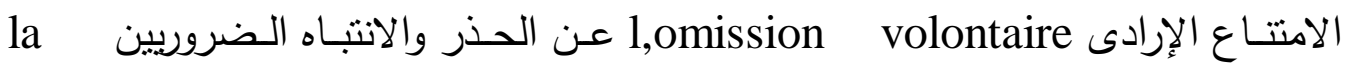
diligence et de 1,attention nécessaire القانون(به (1)، ويعتبر الإهمال الواعى، أثند خطورة وجسامة على المجتمع من الإهمال غير الـواعى؛ ولذللك فـإن المـشرع يشندد العقوبـة فى حـالات الإهمـال الـواعى، فجوهر الإهمال هو إرادة سلوك ينطوى على خطر أمر غير مشروع وإغفال ما كان يجب لمنع هذا الخطر من التحول إلى هذا الأمر، دون أن يشترط فى ذلك الإغفال أن يكون إراديا،

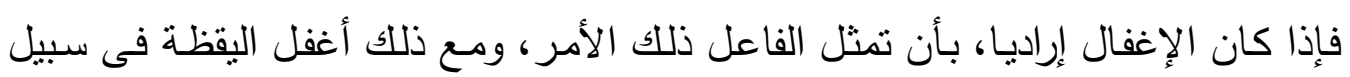
منعه كان فيصل التقرقة فى هذه الحالة بين الإهمال والقصد( ع إن )، وهو ما دار بذهن الجانى

ومخالفة القوانين واللوائح من جانب المهنيين تعد مخالفة لأصول وقواعد المهنة

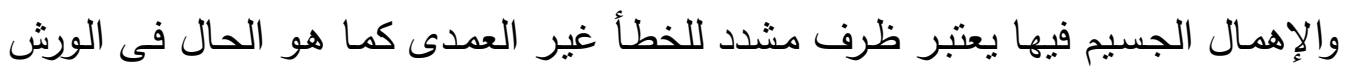

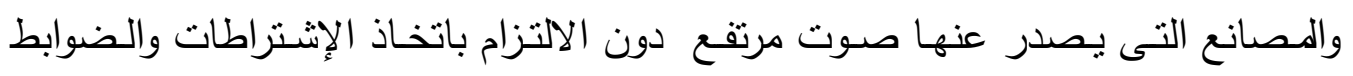
التى تخفض هذا الصوت.

(10r) Vidal (G.) et Magnol (J.), Cours de droit criminel Op. Cit., No. 129 130. P. 176.

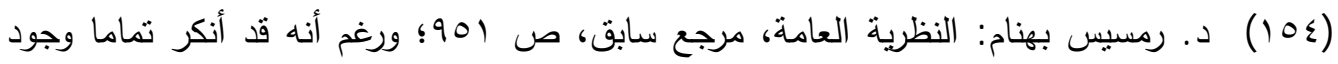

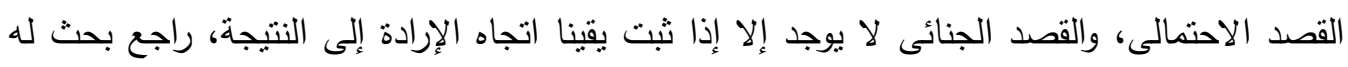

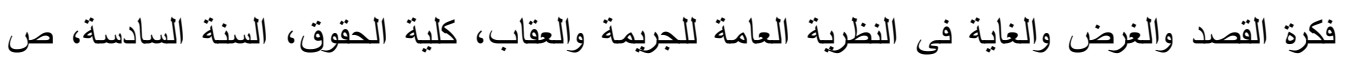

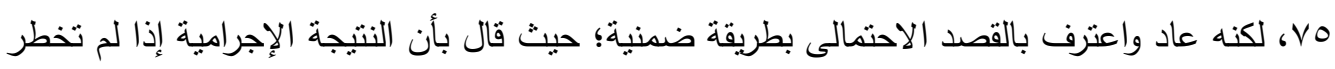

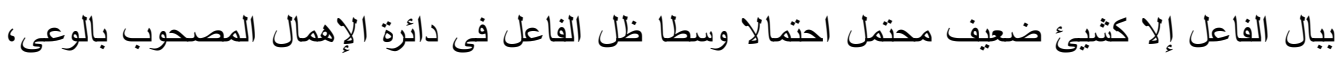

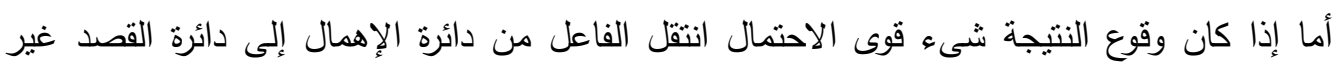

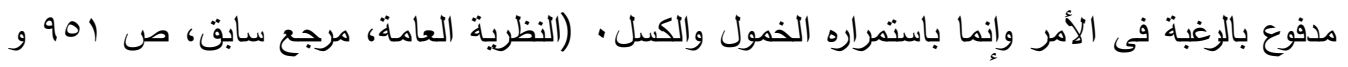

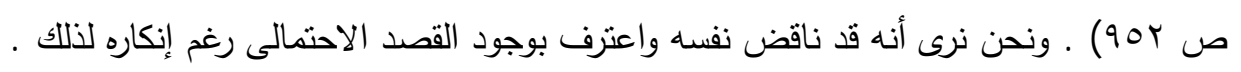




\section{المبحث الرابع}

\section{الجزاءات المفروضة على جرائم التلوث السمع}

المشرع فى غالبية الدول التى سنت نشريعات لتجريم التلوث السمعى لم يقتصر الجزاء فيها على العقوبات الجنائية بل تتوعت الجزاءات مابين الجزاء الجنائى (المطلب الأول)

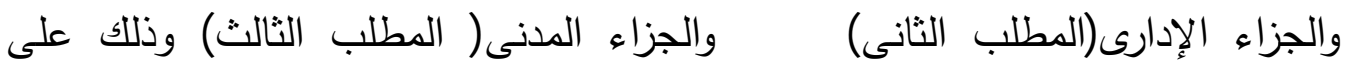
النحوالتالى :

\section{المطلب الأول}

\section{الجزاءات الجنائية فى جر ائم التلوث السمى}

كثير من الدول حول العالم تضمنت تشريعاتها كثير من الجزاءات الجنائية فى قوانين العقوبات والتشربعات البيئية. والجزاء الجنائى هو الأثر القانونى الذى يرتبه المشرع على هنى الجريمة وتتتوع الجزاءات الجنائية مابين العقوبة (الفرع الأول) والتدبير الاحترازى (الفرع

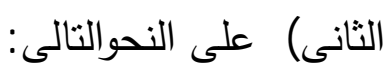

\section{الفرع الأول}

\section{العقوبات الجنائية السالبة للحرية}

وردت عقوبـة الحبس فى التشريعات البيئية وبعض قوانين العقوبـات. ففى فرنسـا

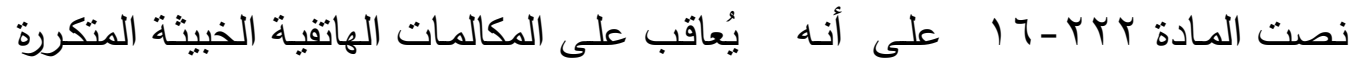
أو الاضطرابات بالضجيج التي تهدف إلى الإخـلال بسلام الآخرين بالسجن لمدة عام

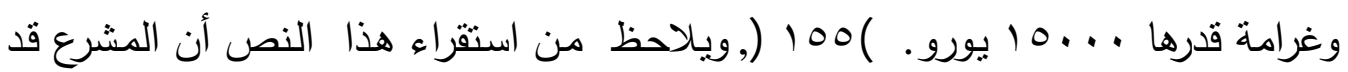
غلظ العقوبـة ولـم يجعـل للقاضـى أى سـلطة تقديريـة وفـى البرتغـال جـاء قـانون

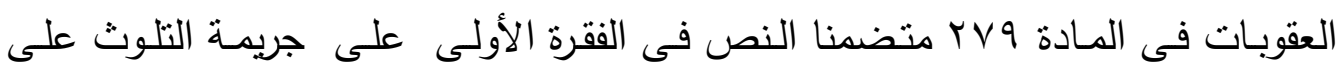

)- 100 art-222-16( Repeated malicious telephone calls or disturbances by noise which aim to disturb the peace of others are punished by one year's imprisonment and a fine of $€ 15,000$. 
النحو التالي - 1" :كل من يسبب التلوث الضوضائي بدرجة غير مقبولة من خلال

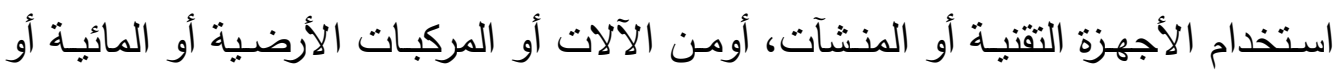

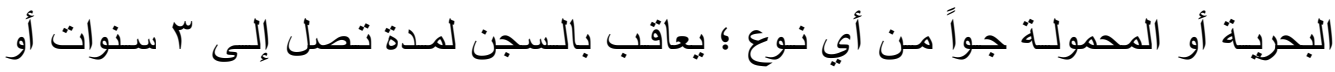

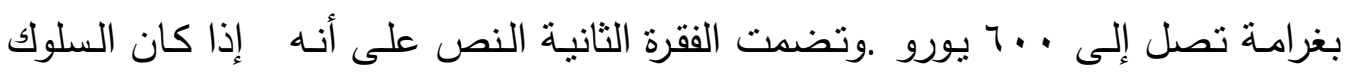
المشار إليه في الفقرة الأولى يتم تتفيذه عن طريق الإهمال، فيحكم على الوكيل بالسجن

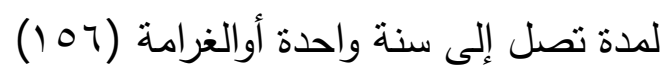

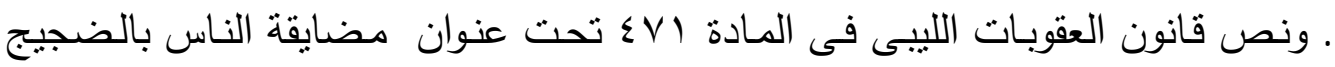
وإقـلاق راحتهم على أنـه ( كل من حصل منـه لغط أو ضـجيج أو أسـاء استعمال أيـة وسيلة من وسائل نقل الصوت أو تكبيره أو حرض الحيوانات على إحداث ضديج وكان

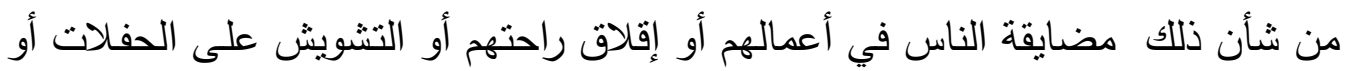

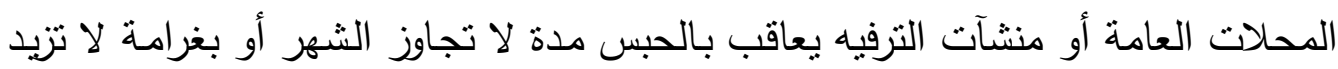

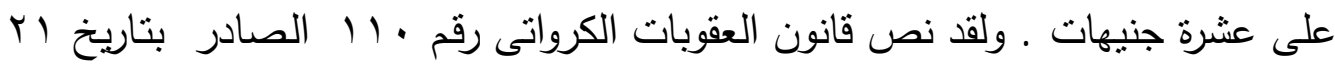

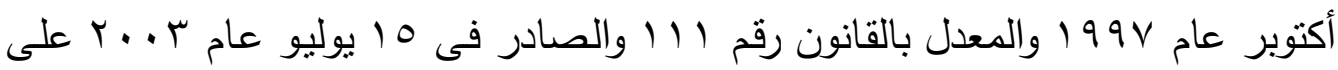
جريمـة التلوث الضوضائى تحت عنوان تعريض البيئة لخطر الضوضاء Endangering the Environment by Noise

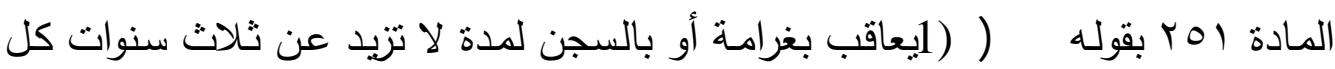
من يصدر ضوضاء من شأنها إحداث أضرار جسيمة بصحة عدد من الأشخاص، خلافًا للأنظمة ونصت الفقرة الثانية على (2) كل من برتكب الجريمة المشار إليها في

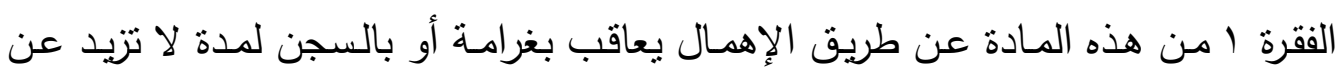

- (156) -. Whosoever, to an unacceptable degree:

1) Causes Noise Pollution through the use of technical appliances or installations, particularly from machines or terrestrial, fluvial, marine or airborne vehicles of whatever kind;Shall be sentenced to imprisonment of up to 3 years or to a fine of up to 600 days.

$r_{-}$.) .If the conduct referred to in no. 1 is carried out through negligence, the agent shall be sentenced to imprisonment of up to 1 year or to a fine. 
سنة.)) OV (ومن استقراء هذا يتضح أن جريمـة الضوضاء العمديـة تكون مشددة العقوبة بخلاف الجريمة التى تقع بإهمال.

وفى البحرين نصت المادة • و ج من قانون العقوبات على (يعاقب بالحبس مدة لاتزيد على ستة أشهر أو بالغرامة التى لاتجاوز خمسين دينارا كل من تسبب عمدا فى إزعاج

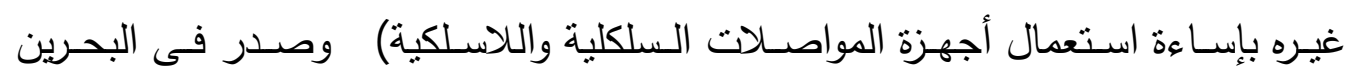

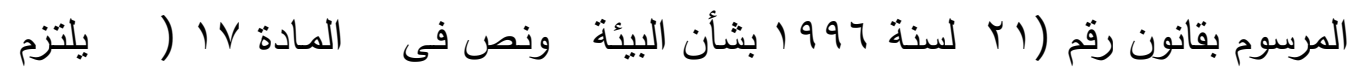
جميع الأثـاص والمشروعات، عند مباشـرة الأنشطة الإنتاجيـة أو الخدميـة أو غيرهـا،

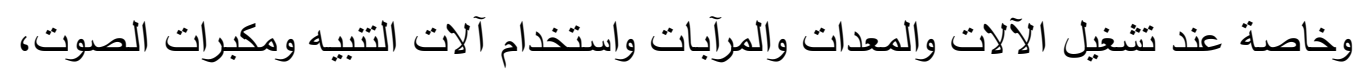

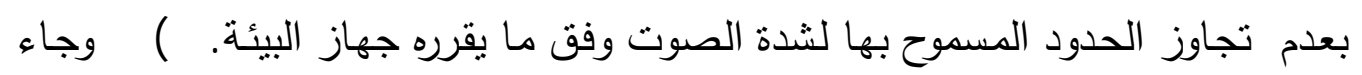

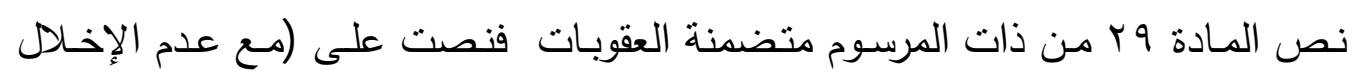
بأيـة عقوبـة أثند ينص عليها قانون آخر ، يعاقب بـالحبس وبغرامـة لا تزبـد على خمسين

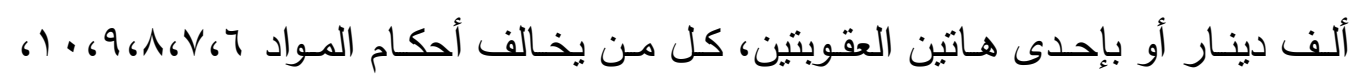

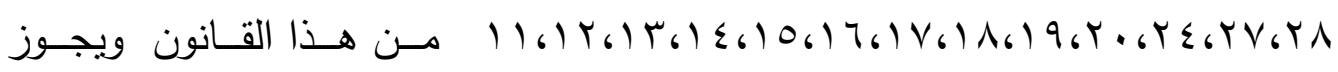
للمحكمة أن تقضي بالإضافة لذلك بغلق الأماكن التي يكون العمل فيها مصدرا للتلوث

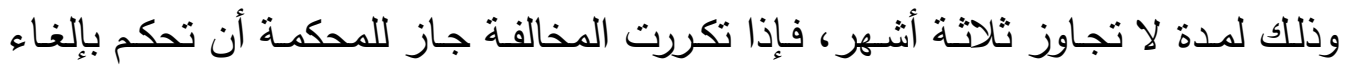
الترخيص . ويعاقب بالحبس مدة لا تجاوز سنة وبغرامـة لا تجاوز ألف دينار أو بإحدى لته

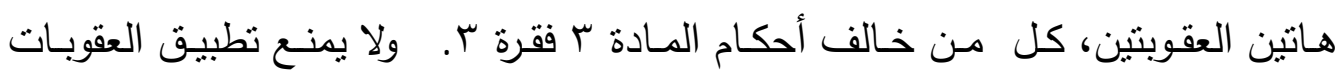

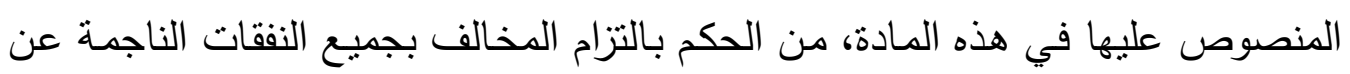
معالجة الأضرار البيئية، وكذلك الحكم بالتعويضات التي قد تترتب عن هذه الأضرار .)

\section{( 157 ) Article 251}

1)) Whoever, contrary to regulations, makes noise which is apt to cause substantial damage to the health of a number of persons shall be punished by a fine or by imprisonment not exceeding three years.

r)) Whoever commits the criminal offense referred to in paragraph 1 of this Article by negligence shall be punished by a fine or by imprisonment not exceeding one year 
وفى تركيا نصت المادةr/ ا من قانون العقوبات التركى رقم سVYor والصادر بتايخ

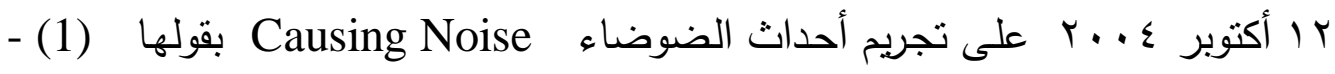
كل مـن أحدث ضـجيجا مخالفـا للالنزامـات المنصوص عليها في القوانين ذات الصلة بحيث يؤدي إلى تدهور صحته أو صحة شخص أخر، يعاقب بالحبس من شهرين إلى إنى

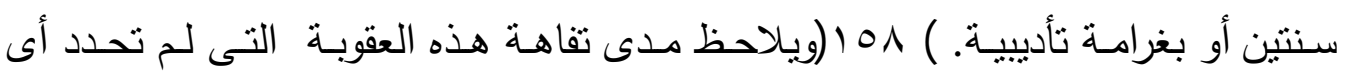

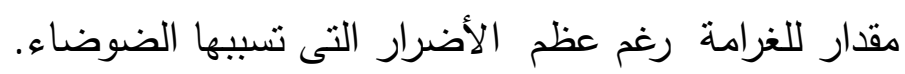

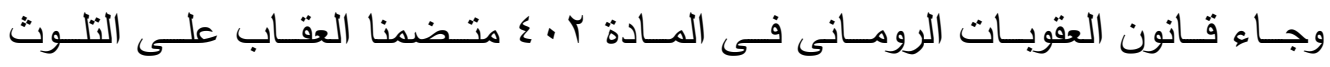
الضوضائى Acoustic pollution بقولها (فعل إصدار الأصوات التي تتجاوز الحدود

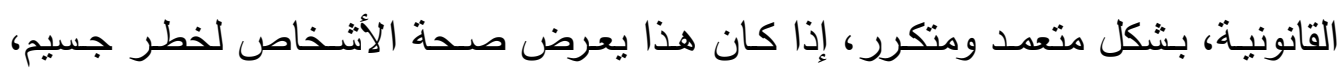

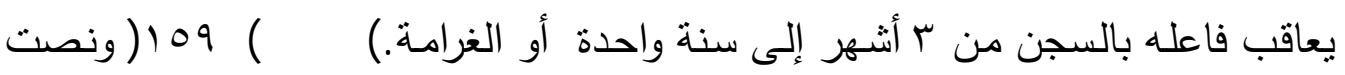

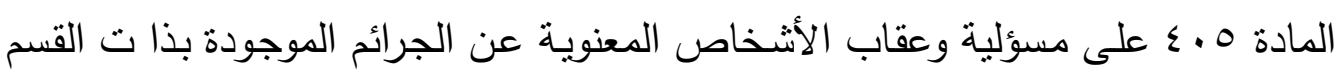
بقولها (ـ يعاقب الأشخاص الاعتباريون على الجرائم المنصوص عليها في هذا الفصل) ويلاحظ أن العقوبة غير رادعة وهى الغرامة التى فى الغالب يحكم بها القضاة فى مثل

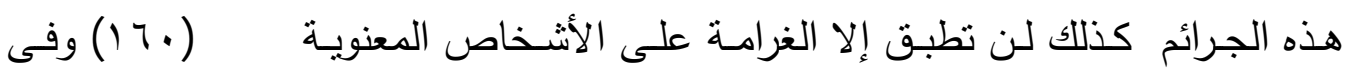

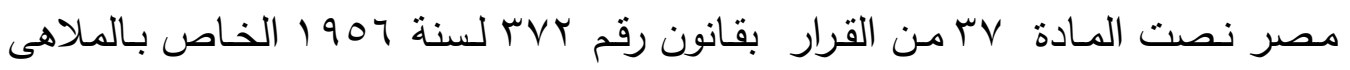

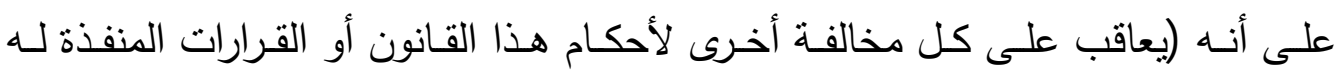

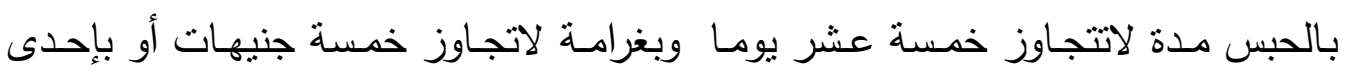

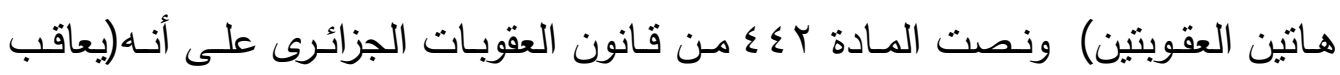

(158) - ARTICLE 183-(1) Any person who causes noise contrary to the obligations set-forth in the relevant laws, in such a way to result with deterioration of one's health, is sentenced to imprisonment from two months to two years, or imposed punitive fine (109) - Art.402 - The act of making sounds that exceed the legal limits, deliberately and repeatedly, if this seriously endangers the health of persons, shall be punished by imprisonment from 3 months to one year or by days/fine -( 17.) - Art.405 - Legal entities shall be sanctioned for the offences provided in the present chapter. 
بالحبس لمدة عشرة أيام على الأكثر من يقلق راحة السكان بالضجيج أو الضوضاء أو

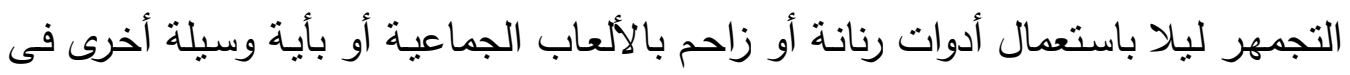

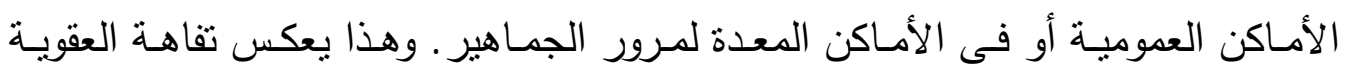

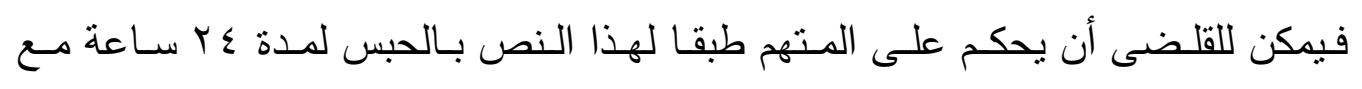
الإيقاف فلم يحدد النص حد أدنى . كذلك تنص المـادة سل مـن قانون حمايـة البيئة الجزائرى على ضرورة الحصول على ترخيص لممارسة الأنشطة الصاخبة. وتنص المادة

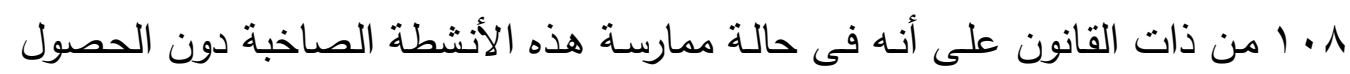

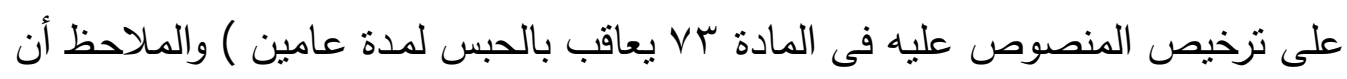

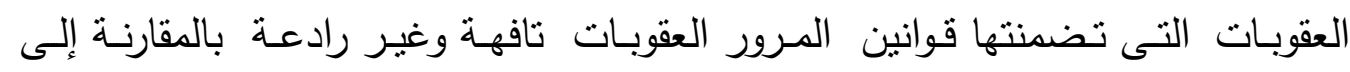

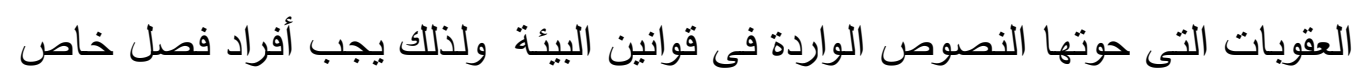
بجرائم النلوث السمعى فى قانون العقوبات مع تغليظها.

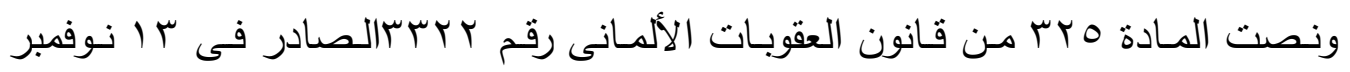

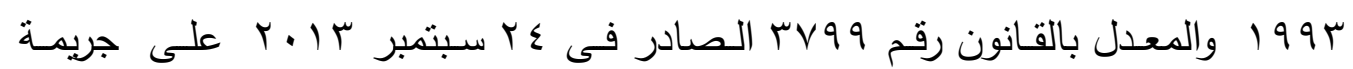
التلوث الضوضائى فى أربع فقرات على النحوالتالى: باتئ رفت 1 - يعاقب بالحبس مدة لا تزيد على ثلاثة سنوات أو الغرامـة كل شخص، أثناء تشغيل منشأة، ولا سيما مصنع أو آلة، بالمخالفة للواجبات المنصوص عليه بليها في القانون الإداري، والتي من شأنها الإضرار بصحة شخص آخر خارج المنطقة التابعة للمنشأة. . أي شخص، أثناء تشغيل منشأة، ولا سيما مصنع أو آلة، متسببا فى انتهاك للواجبات المنصوص عليها في القانون الإداري والتي تعمل على الحماية من الضوضاء

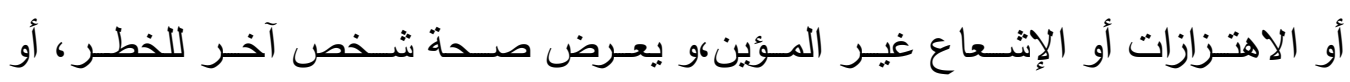

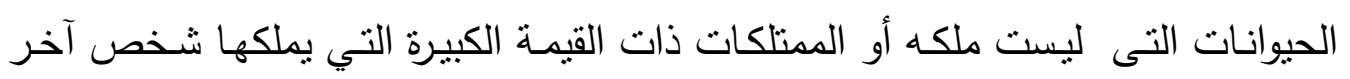
يعاقب بالسجن لمدة لا تزيد عن خمس سنوات أو غرامة مالية . (3) إذا تصرف الجانى بإهمال فالعقوبة تكون - أولا. في الحالات المنصوص

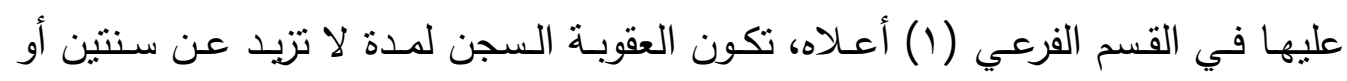


غرامة مالية ؛ ثانيا في الحالات المنصوص عليها في الفقرة الفرعية (r) أعلاه، تكون العقوبة السجن لمدة لا تزيد عن ثلاث سنوات أو غرامة مالية

. (4) لا تتطبق الأقسام الفرعية من ( () إلى (ب) أعلاه على المركبات ذات المحركات

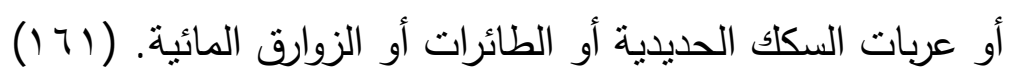

وريلاحظ أن قانون العقوبات الألمانى قد شدد العقبة فى حالة تعدد الجريمة وخفقها فى حالـة لاتصرف بإهمـال كمـا أنـه أعفى المركبـات وعربـات السكك الحديديـة والطـائرات والزوارق المائية لأنها تعتير من وسائل النقل وهى بطبيعتها قابلة للتتقل من مكان إلى الى أخر بصرف النظر عن طبيعة المكان صناعى أو سكنى أو غير ذلك.

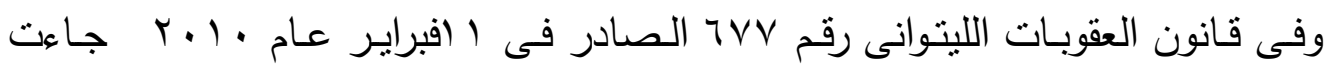
نص المادة • r تحت عنوان الجرائم والمخالفات ضد البيئة والإنسان والصحة في الفقرة الأولى والثانية بقولها ( الثخص الذي ينتهك اللوائح التي تحكم حماية البيئة أو استخدام

(17)-) Whosoever, in the operation of a facility, especially a plant or machine, in violation of duties under administrative law, causes noise which is capable of harming the health of another outside the area belonging to the facility, shall be liable to imprisonment not exceeding three years or a fine.

r)) Whosoever, in the operation of a facility, especially a plant or machine, in violation of duties under administrative law which serve to protect against noise, vibrations or non-ionising radiation, endangers the health of another, animals not his own or property of significant value belonging to another shall be liable to imprisonment not exceeding five years or a fine.

r)) If the offender acts negligently the penalty

1 ) .in cases under subsection (1) above shall be imprisonment not exceeding two years or a fine؛

2 . ) in cases under subsection (2) above shall be imprisonment not exceeding three years or a fine.

§)) Subsections (1) to (3) above shall not apply to motor-vehicles, rail vehicles, aircraft or watercraft. 
الموارد الطبيعية، حيث يشكل ذلك تهديدًا لحياة أو صحة عدد كبير من الأشخاص أو قد يتسبب ذلك في أضرار جسيمة للحيوانات أو النباتات أو عواقب أخرى خطيرة في البيئة،

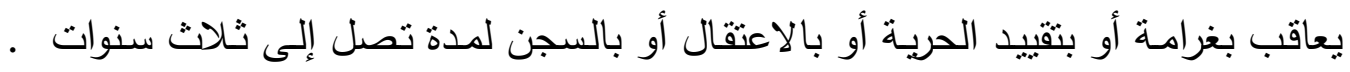

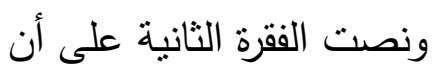

r - - - يعاقب أي شـص يرتكب الفعل المشار إليـهـ في الفقرة ا مـن هذه المـادة، إذا تسبب ذلك في ضـرر جسيم للحيوانـات والنباتات أو عواقب وخيمـة أخرى على البيئة، بغرامـة أو بالاعتقال أو بالسجن لمدة تصل إلى تصل إلى ست سنوات.)) ب 7 ( (ويلاحظ

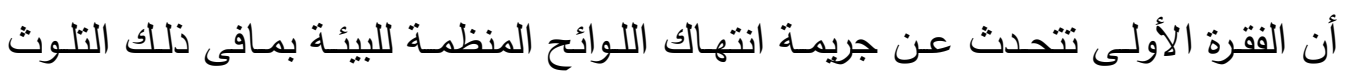
بأنواعه المختلفة والذى يشمل التلوث السمعى وانتهاك لوائح البيئة هـى جريمة من جرائم الخطر ولذلك لاتزبد العقوبة عن ثلاث سنوات سجن ب بخلاف الفقرة الثانية نجدها تتحدث عن جريمة من جرائم الضرر ولذلك كانت العقوبة مغلظة حيث تصل إلى ست سنوات سجن. وِجاء قانون العقوبات الرومانى فى المادة ب • ـ متضمنا العقاب على التلوث الضوضائى Acoustic pollution بشكل متعمد ومتكرر، إذا كان هذا يعرض صحة الأثخاص لخطر جسيم، يعاقب فاعله الهـ

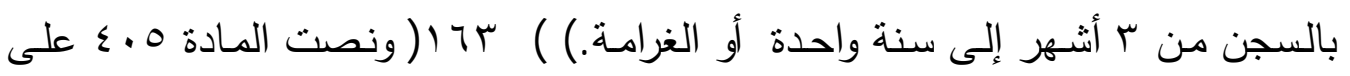

(17r) - . A person who violates the regulations governing environmental protection or the use of natural resources, where this poses a threat to the life or health of a large number of people or this could have caused major damage to the fauna, flora or other serious consequences to the environment, shall be punished by a fine or by restriction of liberty or by arrest or by imprisonment for a term of up to three years. -2- .A person who commits the act indicated in paragraph 1 of this Article, where this causes major damage to the fauna, flora or other serious consequences to the environment, shall be punished by a fine or by arrest or by imprisonment for a term of up to six years.

(37) - Art.402 - The act of making sounds that exceed the legal limits, deliberately and repeatedly, if this seriously endangers the health of persons, shall be punished by imprisonment from 3 months to one year or by days/fine 


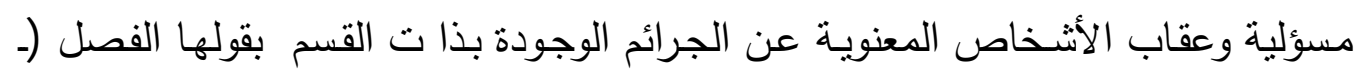

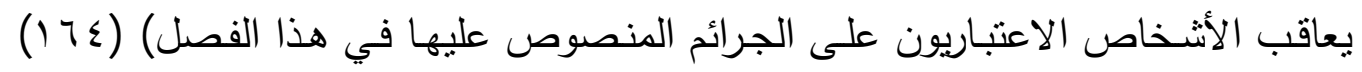

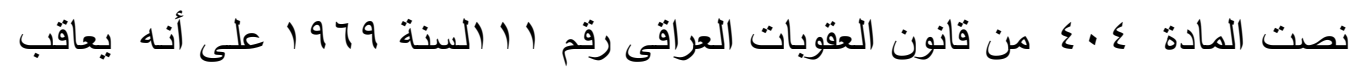
بالحبس مدة لا تزبد على سنة او بغرامة لا تزبد على مائة دينار كل من جهر بأغان أو أو أقوال فاحشة او مخلة بالحياء بنفسه او بواسطة جهاز آلي وكان ذلك في محل عله عام.

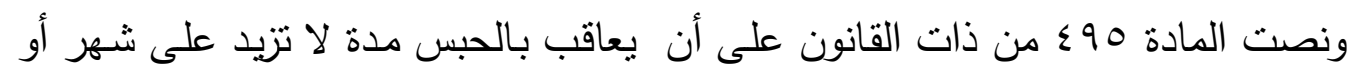

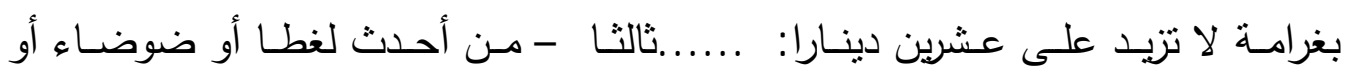

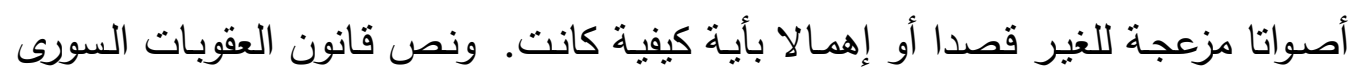

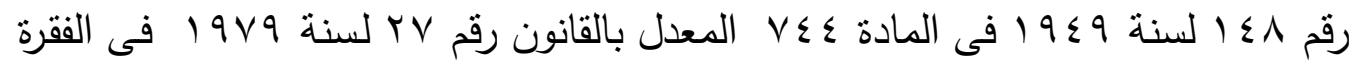
الأولى على أن يعاقب بالغرامة من خمسة وعشرين إلى مائة ليرة: أو من أحدث ضوضهاء أو لغطا على صورة تسلب راحة الأهلين وكذا كل من حرض هذا العمل أو أشترك فيه . وتضمت كذلك قوانين البيئة عقوبـات سالبة للحريـة ومنها نصت المـادة 17 من قانون

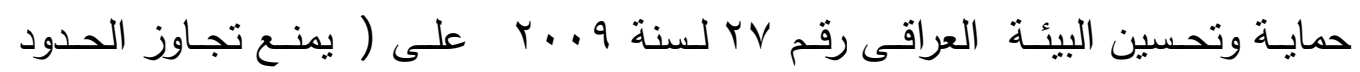

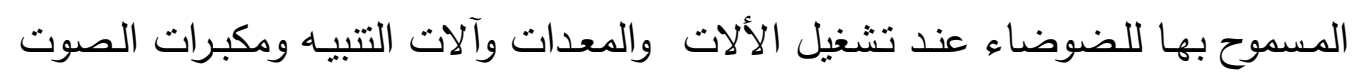

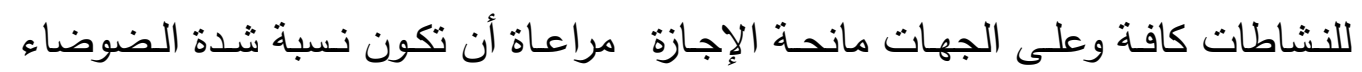
المنبعثة في منطقة واحدة ضمن الحدود المسموح بها في تعليمات يصدرها الوزير

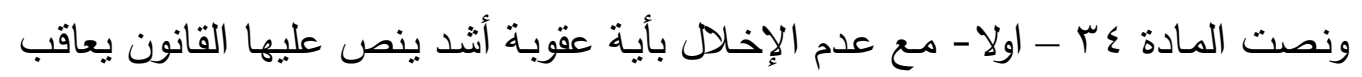
المخالف لأحكام هذا القانون والأنظمة والتعليمات والبيانات الصادرة بموجبه بالحبس الحبس لمدة

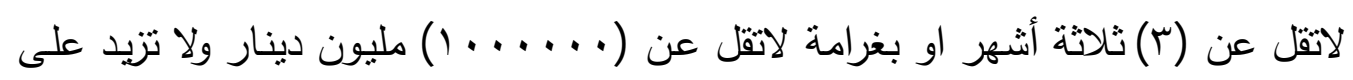

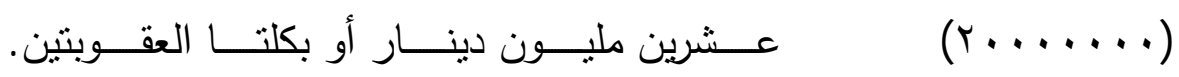
ثانيا - تضاعف العقوبة في كل مرة يتكرر فيها ارتكاب المخالفة.

-( 38) - Art.405 - Legal entities shall be sanctioned for the offences provided in the present chapter. 


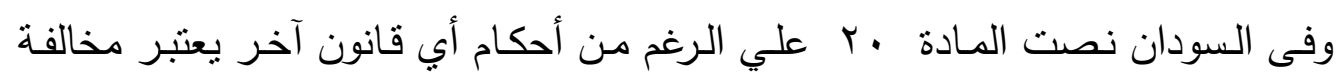

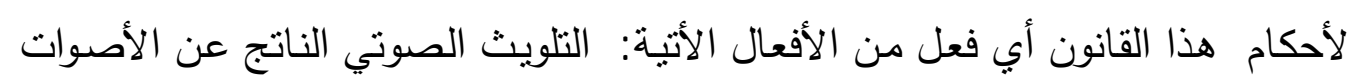

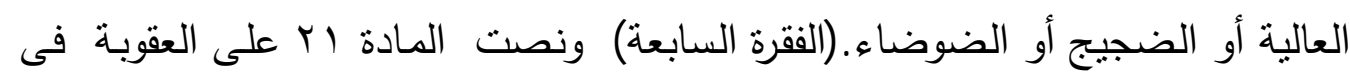

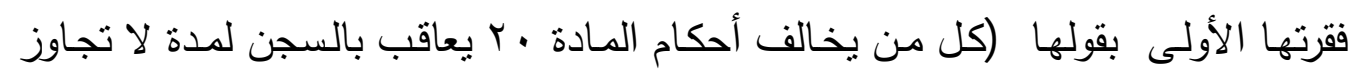
ثلاث سنوات أو بالغرامة التى لا تجاوز عشرة ألف جنيه سودانى أو بالعقوبتين معا بأ بادئ

\section{الفرع الثانى}

\section{العقوبات المالية}

العقوبـة المالية بوجها عام تصيب الذمـة المالية للمحكوم عليه وهى إلزام المحكوم عليـه بـدفع مبلغ مـن المـال يقرره الحكم القضائى ويقدر قيمتهـه ويـرد إلى خزانـة الدولـة

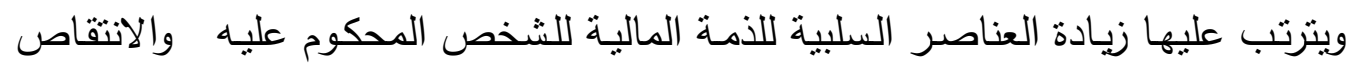
من عناصرها الإيجابيـة. ومن أمتلـة العقوبات التى يترتب عليها زيـادة العناصر السلبية

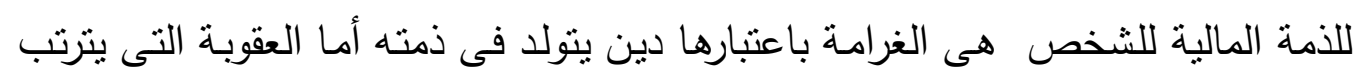

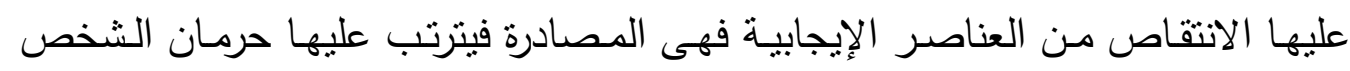

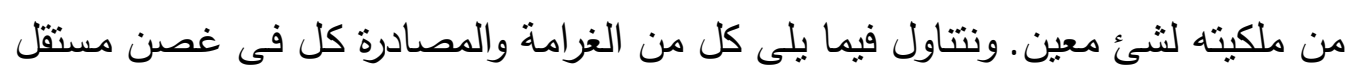
على النحوالتالى: من ملخيى

\section{الفصن الأول}

\section{Amende الفرامة}

أعطى القانون للقاضى سلطة كبيرة فى تفريد عقوبـة الغرامـة حيث نصت المـادة

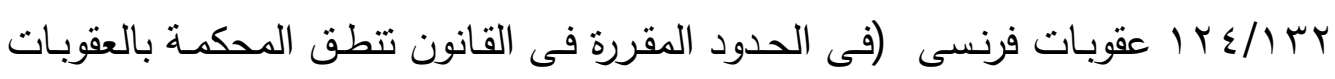
وتحدد نظامها مع مراعاة ظروف ارتكاب الجريمة وشخصية مرتكبها وإذا قضت المحكمة

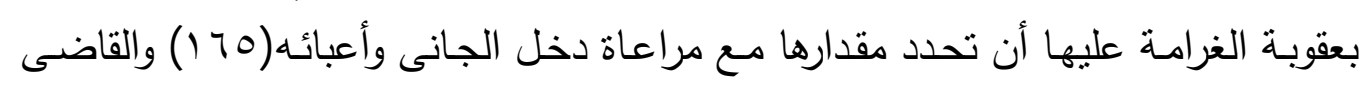

(165) Art. 132-24.- Dans les limites fixées par la loi, la juridiction prononce les peines et fixe leur régime en fonction des circonstances de l'infraction et de la personalité de son auteur. Lorsque la juridiction prononce une peine 
فى سبيله لتحديد مبلـغ الغرامـة اعتماداً على ذلك يتحرى عن المصادر المالية وأعباء الثخص المعنوى حتى يقضى بالغرامة التى تتتاسب معه.

كذلك القاضى له سلطة تقسيط مبلغ الغرامة فى خلال مدة معينة حيث تتص المادة

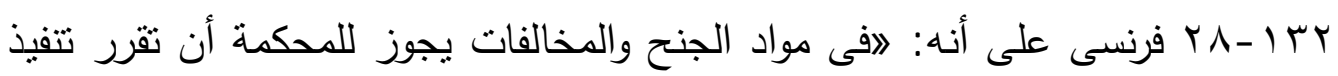
عقوبة الغرامة بالتقسيط خلال مدة لا نزبد على ثلاث سنوات وذللك لاعتبارات جدية ذات

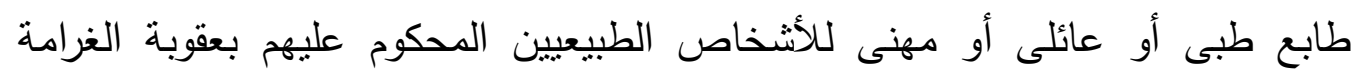
اليومية أو عقوبة وقف رخصة القيادة(7 (17). والغرامة فى الجرائم البيئية ومنها التلوث

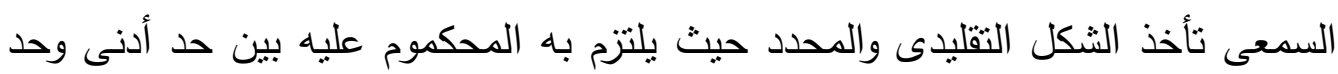

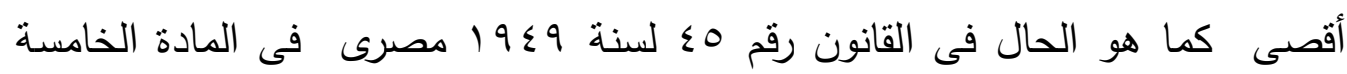
الفقرة الأولى والتى تعاقب على مخالفة أحكامه بالغرامة التى لاتقل عن مائة جنيه ولاتزيد

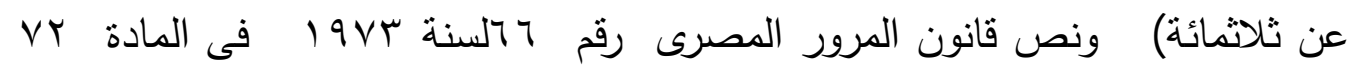
مكرر r : (مضافة بالقانون 100 لسنة 999 (199) حيث نصت على (مع عدم الاخلال بالتدابير المقررة فى هذا القانون او بأية عقوبة اثند فى اى قانون اخر، يعاقب بغرامة لا لاهي تقل عن خمسين جنيها ولا نزيد على خمسمائة جنية مع سحب رخصة القيادة لمدة لا نقل عن ثلاثثن يوما ولا تزيد على ستين يوما، كل قائد مركبة تسبب فى تلوث الطريق العام بالقاء أيه فضلات أو مخلفات بناء أو أيه أنشياء أخرى وكل من قاد مركبة فئ في الطريق

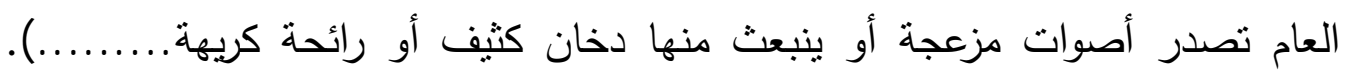

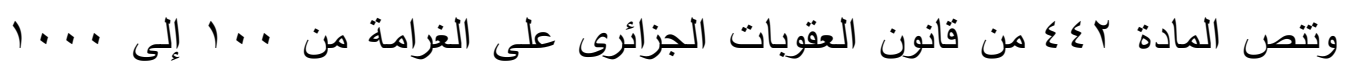

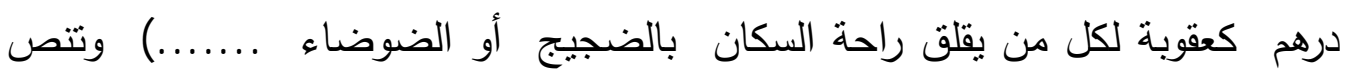

d'amende, elle determine son montant en tenant compte également des ressources et des charges de l'auteur de l'infraction.

(166) Art. 132-28 - En matière correctonnelle ou contraventionnelle, la juridicion peut. Pour motif grave d'ordre médical, familial, = $=$ rofessional ou social, décider que la peine d'amende sera, pendant une periode n'excedant pas trois ans, exécuté par fractions. Il en est de meme pour les personnes physiques condamnées à la peine de jours - amende ou à la peine de suspension du permis de conduire. 
المادة ع V من قانون العقوبات السورى فى الفقرة الأولى على أنه ليعاقب بالغرامة من خمسة وعشرين إلى مائة ليرة من أحدث ضوضاء أولغطا على صورة تسلب راحة الأهلين ) وهى عقوبة تافهة القيمة لاتكفل الحماية الكافية للدصالح التعليمية والصحية وغيرها . وفى البرتغال أيضا نم إصدار لائحة الضوضاء العامة بموجب المرسوم بقانون

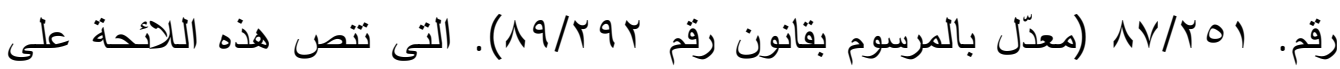
(أن جميع المباني والصناعات والتجارة والخدمات، وكذلك جميع المعدات والعروض هات هده وحركة المرور والإشارات الصوتية و "جميع الأنشطة التي تصدر الصوت بشكل عام

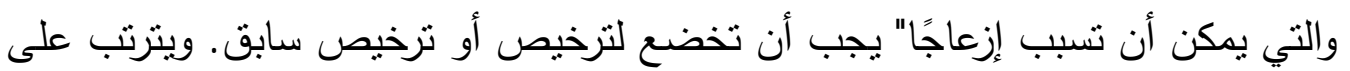
عدم الالتزام بطلب الإذن أو الترخيص فرض غرامات على أي كيانات لا تمنتل لهذا الالتزام . يمكن أن تتراوح هذه الغرامات بين PTE 00 و 50.000 و 00 \$. والملاحظ هنا أن قيمة الغرامة كبيرة وهو مايحقق الردع العام والخاص. وقد يكتفى المشرع بتحديد الحد الأقصى للغرامـة تاركا للقاضى سـلطة النزول بها إلى الدرجات الدنيا منهـا كمـا هو الحسال فى المـادة بvو الفقرة الثانيـة مـن قانون العقوبـات المصرى التى تتص على عقاب كل من يصدر منه لغط بالليل أو غاغة مما يكدر راحة السكان بالغرامة التى لاتجاوز خمسة وعشرون قرشا) .

وفى أحيانا أخرى يحدد المشرع الحد الأدنى للغرامة مع ترك الحد الأقصى لسلطة

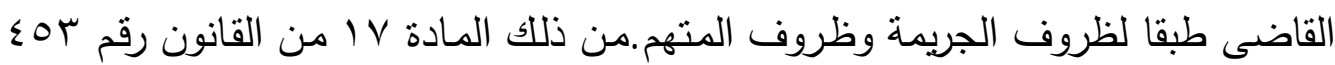

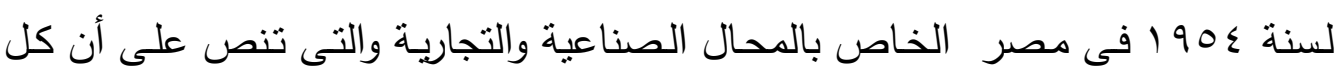
مخالفة لأحكام هذا القانون أو القرارات المنفذة لله يعاقب مرتكبها بغرامـة لاتقل عن مائة جنيه) .

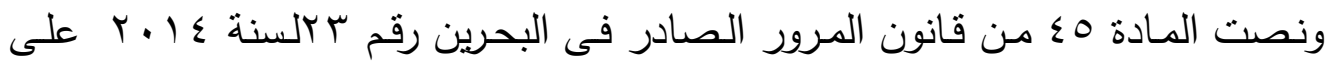
(مع عدم الإخلال بالتدابير المقررة وفقاً لأحكام هذا القانون أو بأية عقوبة أثند منصوص عليها في أي قانون آخر ، يعاقب بغرامة لا نقل عن عشرين ديناراً ولا تجاوز مائة دينار

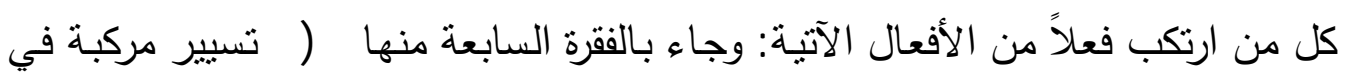


الطريق العام تصدر منها أصوات مزعجة، أو ينبعث منها دخان كثيف أو رائحة كريهة، أو يتطاير من حمولتها أو تسيل منها مواد قابلة للاشتعال أو مضرة بالصحة أو مؤثرة على صلاحية الطريق للمرور أو يتساقط من حمولتها أثياء تشكل خطراً على مستعملي

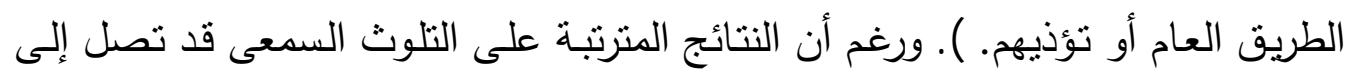

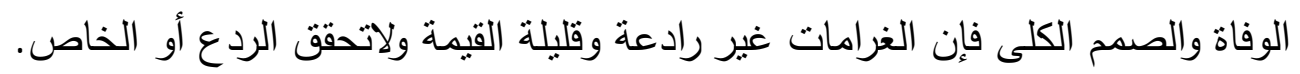
وفى الهند نجد أن قانون العقوبات الهندي هو التشريع الرئيسي في مجال القانون الجنائي الذي ينص على أحكام جزائية موضوعية. فقى الفصل الرابع عشرمنه تتناول

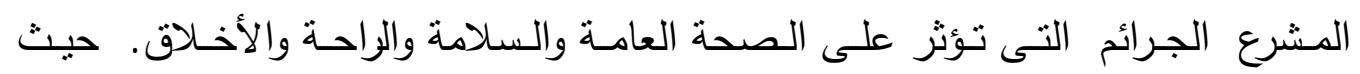
تتص المادة ^جr على" :أن يكون الثخص مذنبًا بارتكاب جريمة الإزعاج العام إذا قام بأي فعل غير قانونى أو ارتكب أي تقصير بتسبب في أي إصـابة أو خطرإصـابة

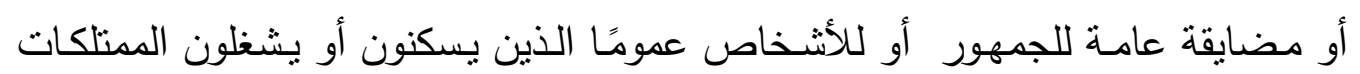
في المنطقة المجاورة، وكل من يتسبب في إصـابة أو إعاقـة أوإحداث خطر أو إزعاج

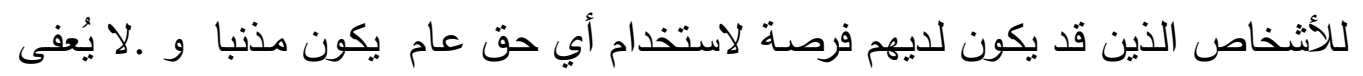

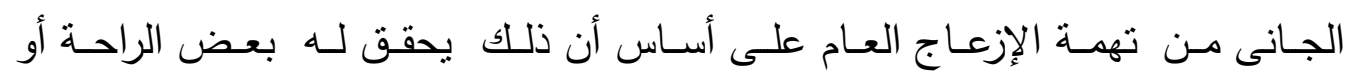

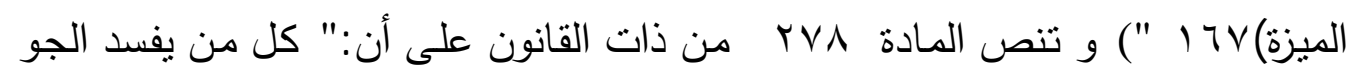

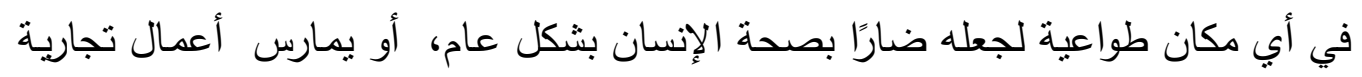
في الحي أو على طول الطريق العام، يُعاقب بغرامة قد تصل إلى ل ..

(1 TV) - Section 268 provides:

" a person is guilty of public nuisance who does any act or is guilty of any illegal omission which causes any common injury, danger or annoyance to the public or to the people in general who dwell or occupy property in the vicinity, or which must necessarily cause injury, obstruction, danger or annoyance to persons who may have occasion to use any public right .

A common nuisance is not excused on the ground that it causes some convenience or advantage

( $17 \uparrow$ ) - Section 278 provides : 
وتنص المادة • و ع على" : كل من يرتكب إزعاجًا عامًا في حالة لا يعاقب عليها هذا

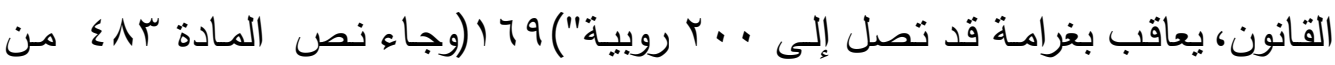
قانون العقوبات الليبى تحت عنوان الألعاب النارية بالنص على أن (كل من أطلق

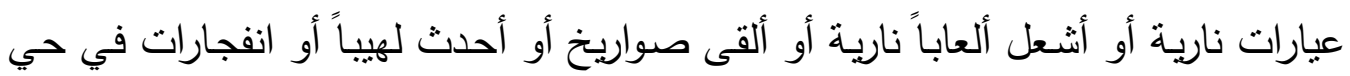
مأهول أو في أمساكن مجاورة لـه أو في طريـق عـام أو في اتجاهها دون ترخيص مـن

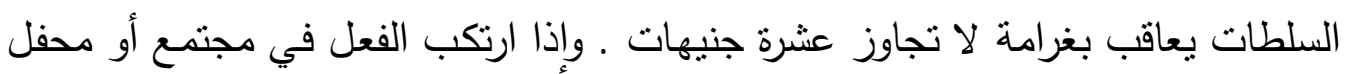
كانت العقوبة الحبس الذي لا تزيد مدته على شهر .

\section{الفصن الثانى}

\section{Confiscation : المصادرة}

تتضمن المصادرة إيلاماً ذا طبيعة مالية يتمثل فى نزع ملكية المال محل المصادرة

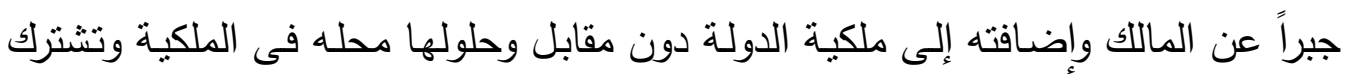

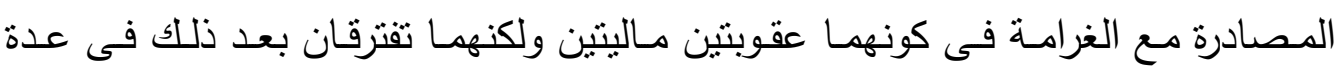
مواضع: فالغرامة تتشئ للدولة مجرد حق دائنية وهو حق شخصى فى ذمة المحكوم عليه

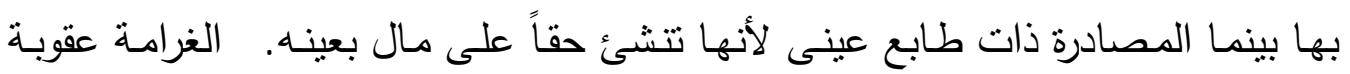

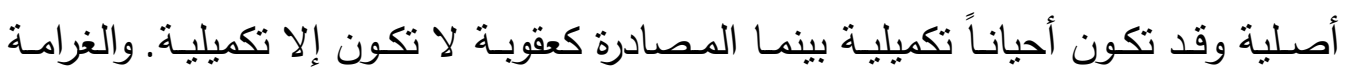
الجنائية لا تكون إلا عقوبة بينما المصادرة قد تكون بالإضافة إلى ذلك تعويضاً أو تدبيراً

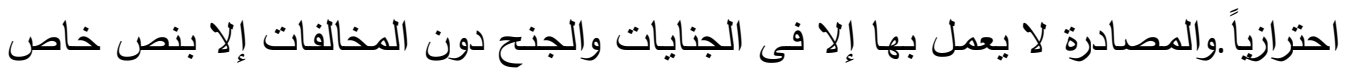

"whoever voluntarily vitiates the atmosphere in any place so as to make it noxious to the health of a person in general, dwelling or causing on business in the neighborhood or

passing along a public way, shall be punished with fine which mayextend to Rs 500".

(179) - Section 290 provides :

"whoever commits a public nuisance in a case not otherwise punishable by this Code, shall be punished with fine which may extend to Rs 200. 
فيها ( • V ) ولقد عرفت محكمـة النقض المصرية المصادرة بأنها : لإجراء الغرض منـه

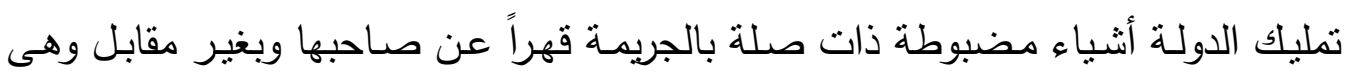
عقوبة اختيارية تكميلية فى الجنايات والجنح إلا إذا نص القانون على غير ذلك فلا يجوز الحكم بها إلا على شخص ثنتت إدانته وقضى عليه بعقوبة أصلية ( V ) ).

وفى الفقه الفرنسى هى نقل ملكية الثئ المصادر إلى الدولة بحكم قضائى ويترتب عليها فقدان الشخص للمال الذى تم مصادرته ولا يتزتب على نزع ملكية هذا المال أى نى خصم فى مقدار الضرائب المستحقة على الثخص ( IVY) . وجعل المشرع الفرنسى مـن المصادرة الخاصـة عقوبـة يتم توقيعها على المحكوم

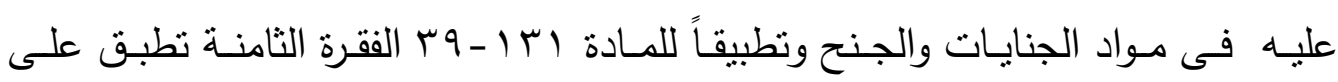
الأشياء التى استخدمت أو كانت معدة للاستخدام فى ارتكاب الجريمـة وكذلك الأشياء

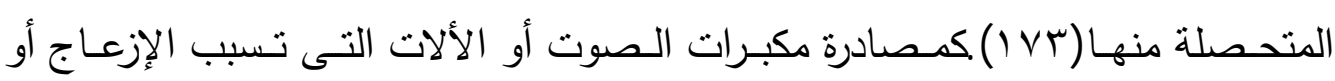
تصدر أصوات مرتفعة

و تــشمل المنقـولات التــى يحـددها القــانون أو اللائحسـة التـى تعاقـب علــى

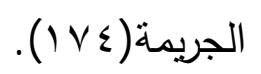

(170) Stefani (G.) levasseur (G.) et bouloc. Op. Cit., No 536. P. 403.

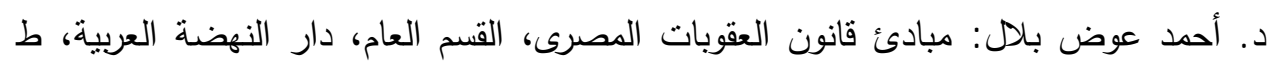

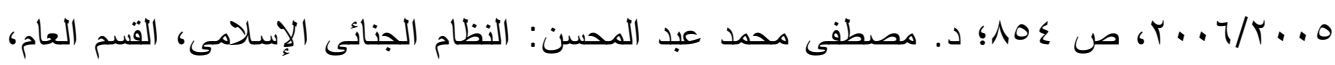

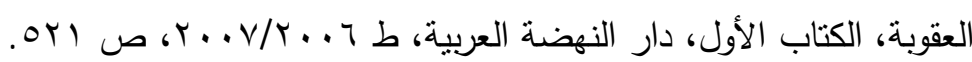

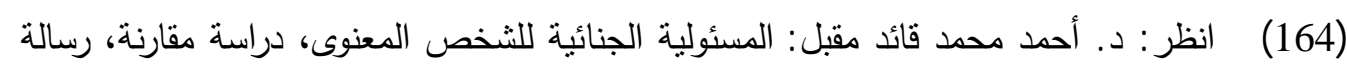

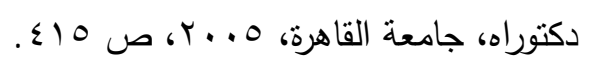
(172) Boiazrd (M.) Amende, confiscation affichage ou communication de la decision Rev. Soc. 1993, P. 338.

(173) La confiscation de la chose qui servi ou était destiné à commettre l'infraction ou de la chose qui en est le produit.

(174) Boiazrd (M.) . Op. Cit., P. 338. 
ولقد حددت المادة اس ا - (Y عقوبات فرنسى نظام المصادرة بالنسبة للثخص المحكوم عليه حيث نصت على أن عقوبة المصادرة تكون وجوبية بالنسبة للأشياء التى يعتبرها القانون خطرة أو ضارة والتى ترد على الثئ أو الأداة المضبوطة سواء كان معداً

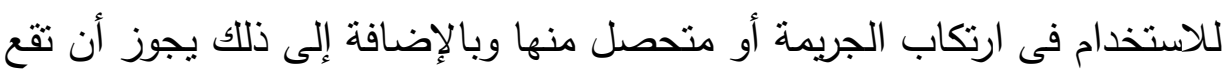

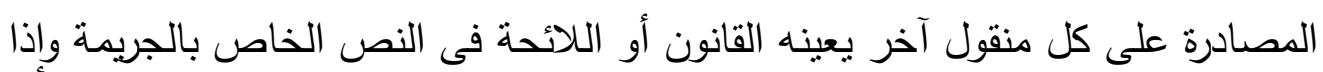
لم يضبط الثئ المراد مصادرته ولم يمكن تقديمه للجهات المختصة يؤمر بمصادرة قيمته

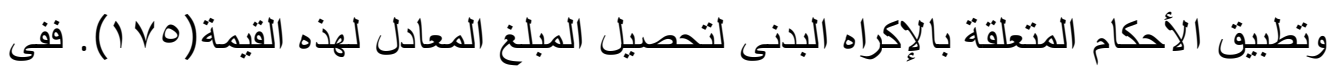
مصر صدر القانون رقم 0ـ لسنة 9 ـ 9 الذى جرم فى المادة الخامسة منه أستخدام مكبرات الصوت إلا بتصريح وفى حالة مخالفة ذلك يعاقب المخالف بالحبس الذى لايزيد عن خمسة عشر يوما والغرامة التى لاتزيد على عشرة جنيهات أو إحدى هاتين العقوبتين

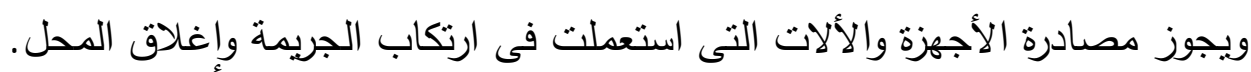

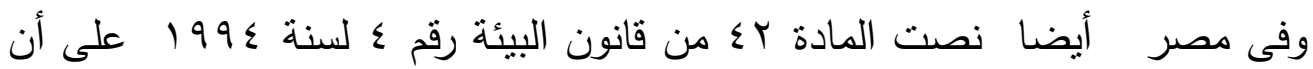
تلتزم جميع الجهات والأفراد عند مباشرة الأنشطة الإنتاجية أو الخدمية أو غيرها وخاصة عند تشغيل الآلات والمعدات واستخدام آلات التتبيه ومكبرات الصوت بعدم تجاوز الحدود المسموح بها لمستوى الصوت وعلى الجهات مانحة الترخيص مراعاة أن يكون مجموع الأصوات المنبعثة من المصادر الثابتة والمتحركة في منطقة واحدة في نطاق الحدود

(175) Art. 131-21. - La peine de confiscation est obligatoire pour les objets qualifies, par la loi ou le règlement, dangereux ou nuisibles. La confiscation porte sur la chose qui a servi ou était destiné à commettre l'infraction ou sur la chose qui en est le produit, à l'exception des objets susceptibles de restitution. En outré, elle peut porter sur tout objet mobilier défini par la loi ou le règlement qui réprime l'infraction. La chose qui est l'objet de l'infraction est assimilée à la chose qui à servi à commettre l'infraction ou qui en est le produit au sens du deuxieme alinéa. Lorsque la chose confisquée n'a pas été saisie ou ne peut être représentée, la confiscation est ordonnée en valeur. Pour le recouvrement de la somme rprésentative de la valeur de la chose confisquée. Les dispositions relatives à la = contrainte par corps sont applicables. La chose confisquée est. sauf disposition particulière prévoyant sa destruction ou son attribution. Dévolue à l'Etat. Mais elle demeure grevée. à concurrence de sa valeur, des droits reels licitement consitués au profit de tiers. 
المسموح بهاوالتأكد من التزام المنشأة باختيار الآلات والمعدات المناسبة لضمان ذلك بوتبين اللائحة التفيذية لهذا القانون الحدود المسموح بها لمستوى الصوت ومدة الفترة الزمنية للتعرض له. ونصت المادة NV من ذات القانون على العقوبة المترنبة على مخالفة هذه المادة بقولها ( يعاقب كل من يخالف حكم المادة بـ (فقرة أولى) من هذا القانون بغرامة لا تقل عن خمسمائة جنيه ولا تزيد على ألفى جنيه مع الحكم بمصادرة

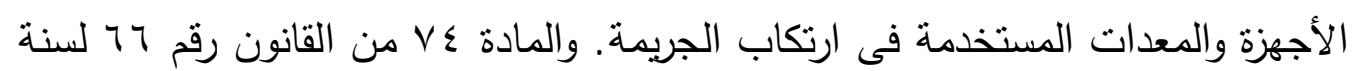
بلا9 ا فى مصر الخاص بالمرور والتى تتضمن الحكم بمصادرة الأجهزة المستخدمة فى ارتكاب الجريمة. وهذه العقبة كما تطبق على الثخص الطبيعى تطبق على الثخص المعنوى حيث يتم مصادرة الألات والأجهزة التى سببت التلوث الضوضائى . وقد تككن المصادرة جوازية وليست وجوبية كما هو الحال فى المادة سج من القانون رقم

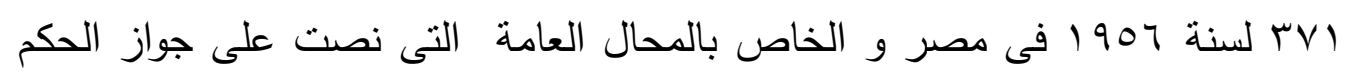

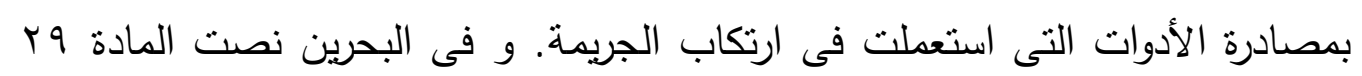

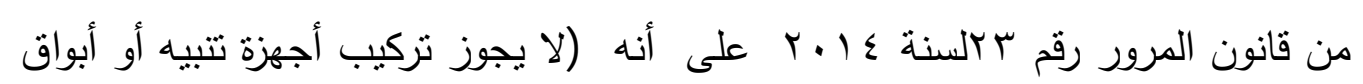
هوائية أو ما يمانلها من أجهزة أو مصابيح أو وضع ستائر معدنية أو غيرها من الأشياء

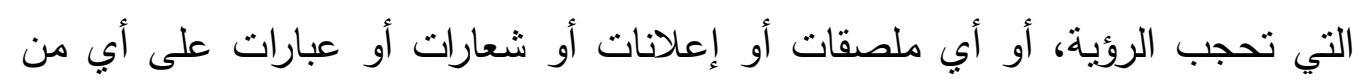
أجزاء المركبة الداخلية أو الخارجية إلا طبقاً للشروط والإجراءات التي تحددها اللائحة التتفيذية والقرارات الصادرة تتفيذاً لهذا القانون، وفي حالة المخالفة جاز ضبطها ألهاء أو إزالتها على نفقة المخالف والحكم بمصادرتها .)

\section{المطلب الثانى}

\section{التدابير الاحتزازية}

كثير من التشريعات البيئية الحديثة نصت على قائمة من التدابير الاحترازية، التى غالباً ما تكون ذات صفة تبعية أو تكميلية تطبق إلى جانب العقوبات الأصلية المقررة 
للجريمة. وقد ذهب جانب من الفقه(VT) إلى إبراز الدور الهام لهذه التدابير للحد من أثار جرائم التلوث السمعي ومن أهمها:

1 - كما سبق من سياق كثير من النصوص ثبت أن التطبيق العملي لهذه العقوبات يظهر عدم كفاية العقوبات التقليدية في منع وقوع الجريمة وردع الجانى؛ فالعقوبات السالبة للحرية في قوانين مكافحة التلوث السمعي غير رادعة و نادراً ما يقضى بها، هذا من ناحية ومن ناحية أخرى فإن الغرامة تكون تافهة فى أغلب الجرائم وفى ذات الوقت

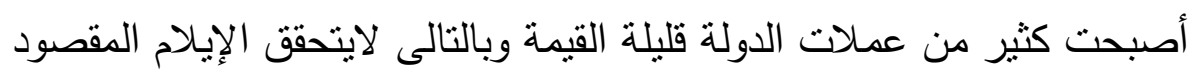
r- إضافة إلى ذلك فإن العقوبات الأخرى بمافيها الحبس والغرامة لا تكفى لإيقاف مصدر التلوث عن الاستمرار في تأثيره الضار على الصحة والراحة والسكينة العامة بخلاف الغاء الترخيص والغلق الذى يضع حدا للأنشطة الضارة بالراحة والسكينة والصحة ويمنع وقوع الجريمة مستقبلا ..

r- القانون الجنائى لله دور وقائى فى السياسة الجنائية الحديثة يحول دون وقوع الجريمة بتطبيق هذه التدابير الاحترازية. ففى الحالات التى يكون نشاط الجانى فيها

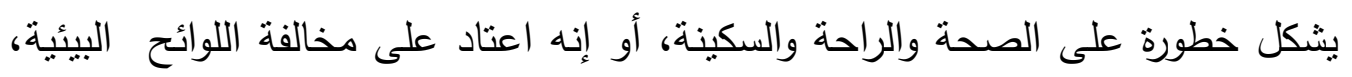
رغم إنذاره من جهة الإدارة، بتركيب المعدات الفنية الضرورية التى تحول دون إزعاج

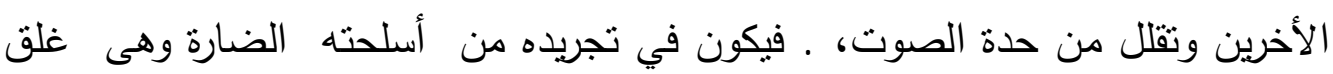

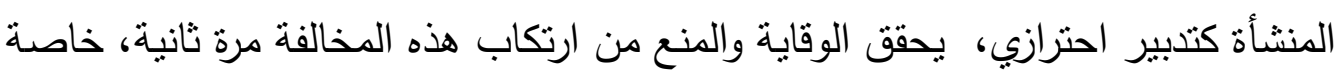

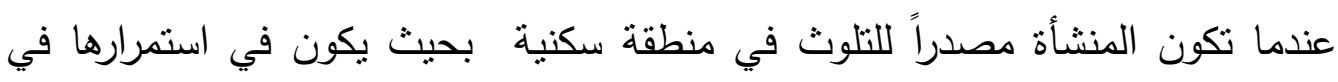
(IVV). ممارسة نشاطها إلحاق أضرار هائلة للقاطنين بجوارن ومن أهم التدابير الوقائية (الاحترازية) المقررة في مجال التلويث الضوضائي مايأتى: (IVT) د. محمد مؤنس محب الدين، البيئة في القانون الجنائى، مكتبة الانجلو المصرية بالقاهرة، 199. (Y ) د. (IVV)

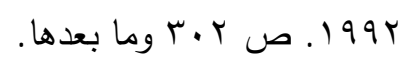




\section{الفرع الأول}

\section{غلق المنشأة أو المؤسسة}

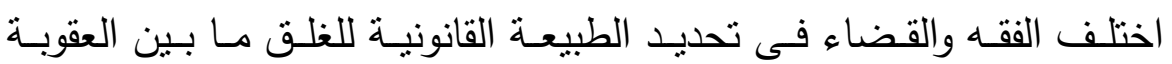

والتدبير فذهب اتجـاه إلى أن جزاء غلق المؤسسة هو إجـراء وتدبير مـن تدابير الأمـن والوقايـة وليس عقوبـة والغلق هو إجراء يتضمن وضـع نهايـة للحالة الخطرة المتمنلة فى إهى

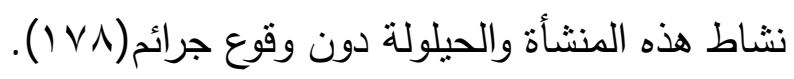

وفى هذا الاتجاه ذهبت محكمـة النقض الفرنسية بأن إغلاق المنشأة يعتبر تدبيراً

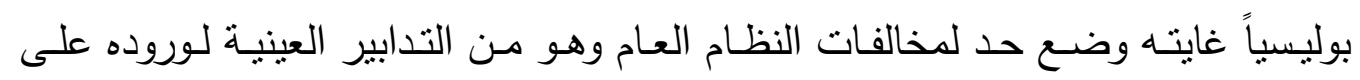

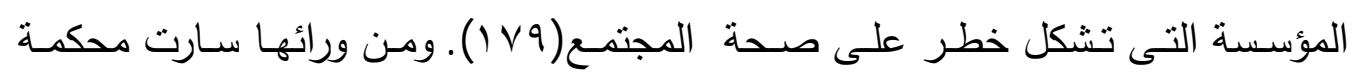
النقض المصرية على ذات النهج حيث قضت بـأن الغلت ليس عقوبـة مـن العقوبـات

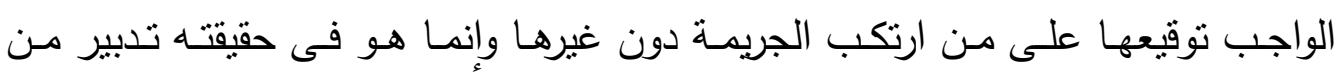

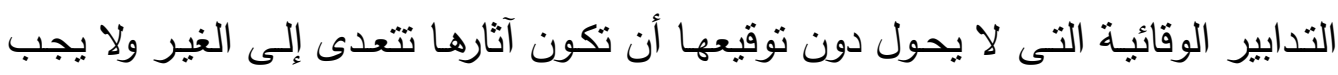

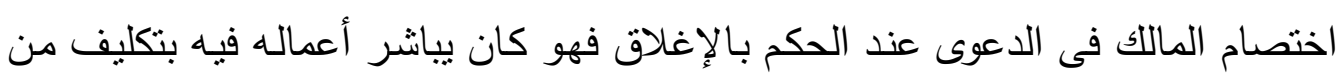
صاحبه( •) (1) (1).

وذهب اتجاه آخر إلى أن الغلق هو جزاء مختلط أو ذو طبيعة مزدوجة فهو يجمع بين العقوبة والتدبير فى ذات الوقت.

(178) Merle (R.) et Vitu (A.) : traité de droit criminel T.I. edition cujas Paris. 1988, P. 870.

وراجع أيضاً: د. عمر السعيد رمضان: فكرة النتيجة مجلة القانون والاقتصاد، عام (971، ص

(19.

(179) Crim 23 Juille 1958 B.C. No 564; 5 Mai 1965, J.C.P. 1966. I. No 14609.

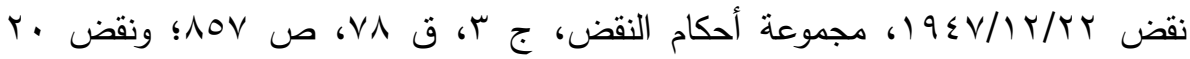

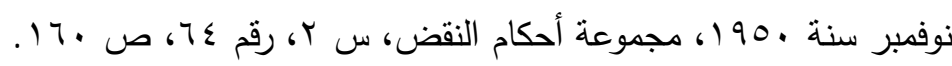


فهو عقوبـة لمـا فيـه من إيـلام يصيب الذمـة الماليـة للمحكوم عليه سـواء كان هو المالك أو المـدير للمؤسسة وهـو تدبير فـى ذات الوقت لأن الهدف منـه الحيلولـة دون ارتكـاب جـرائم وحمايـة المجتهـع مـن الخطـر النـاتج مـن نـشاط هـــه المؤسـسة غيـر

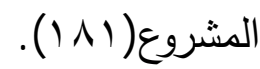

ونحن نتفق مع الرأى الذى يرى أن عقوبة الغلق ذو طبيعة مزدوجة و هو الرأى الراجح.

وقد نصت على عقوبة الغلق المادة ( آI ـ r إ) عقوبات فرنسى وتستوجب هذه

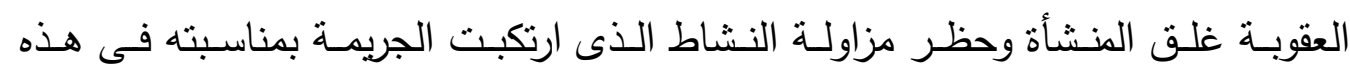

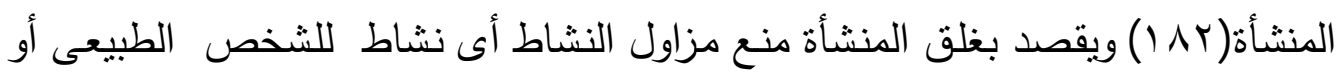
المعنوى فى المكان الذى ارتكبت فيه أو بسببه جريمة تتعلق بهذا النشاط.

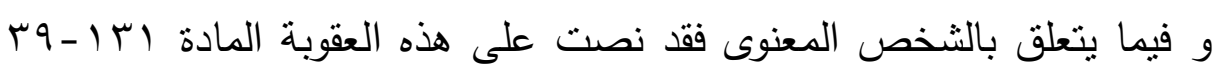
من قانون العقوبات بقولها : لايجوز أن توقع على الشخص المعنوى إذا ارتكب جناية أو جنحة عقوبة أو أكثر من العقوبات الآتية إذا نص عليها القانون ..... وهى غلق المنشآت أو واحد أو أكثر من فروع المشروع الذى استخدم فى ارتكاب الجريمة وذلك بصفة نهائية

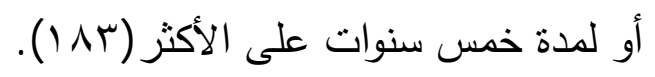

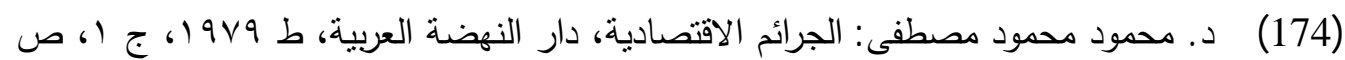
. 10r 101 (182) Art 131 - 33 - La peine de Fermeture d'un établissement emporte l'interdiction d'exercer dans celui - ci l'activite À l'occasion d'exercer dans celui - ci l'activité à l'accasion de laquelle l'infraction a étè commise.

(183) Art. 131-39.- Lorsque la loi le prévoit à l'encontre d'une personne morale, un crime ou un délit peut être sanctionné d'une ou de plusieurs des peines suivantes:

4o La fermeture definitive ou pour une durée de cinq ans au plus des établissements ou de l'un ou de p;usieurs des éstablissements de l'entreprise ayant servi à commettre les faits incriminés. 
ومن التشريعات البيئية المصرية التى نصت على غلق المنشأة كعقبة تكميلية،

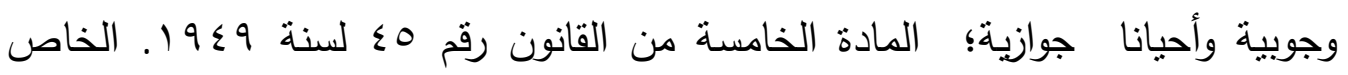
بتتظيم استعمال مكبرات الصوت على إنه "في حالة العود تضاعف العقوبة في حديها الأدنى والأقصى فضلاً عن إغلاق المحل الذى قام بالتركيب لمدة لا تجاوز سبعة أيام" .

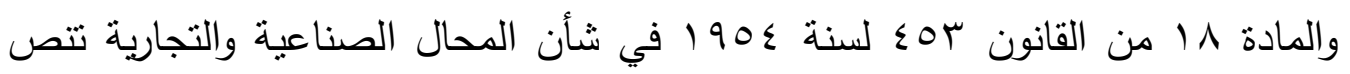
على إنه "مع عدم الإخلال بأحكام المادة السابقة يجوز للقاضى أن يحكم بإغلاق المحل المدة التى يحددها في الحكم أو إغلاقه أو إزالته نهائياًا. ولخطورة بعض الأثشطة على الصحة والسكينة العامة وماتتسبب فيه من أضرار

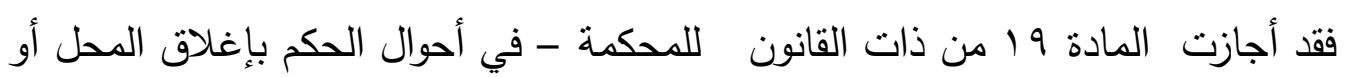
إزالته - أن تأمر بالنفاذ رغم الطعن على الحكم بالاستئناف وينفذ الحكم بالإغلاق أو

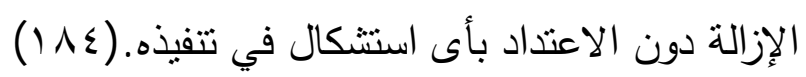

وتكون عقوبة الغلق وجوبية لايملك القاضى حيالها أى سلطة تقديرية كما هو

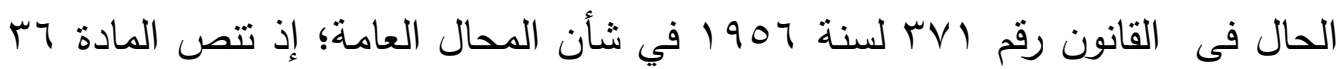

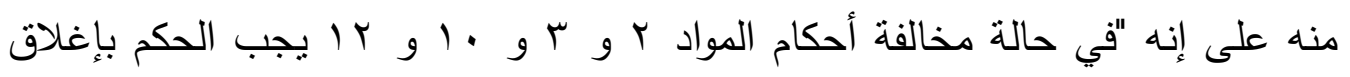

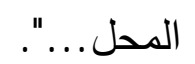

\section{الفرع الثانى}

\section{التلابير المهنية (حظر ممارسة النشاط)}

نص المشرع الفرنسى على هذه العقوبة فى المادة اس / / ب عقوبات، بقولها : "إذا

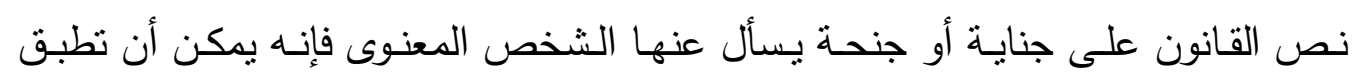

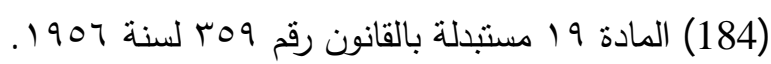

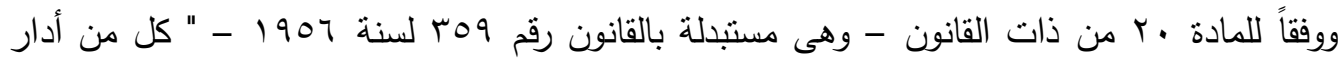

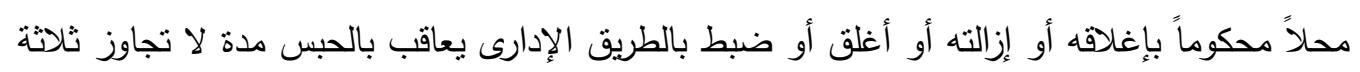

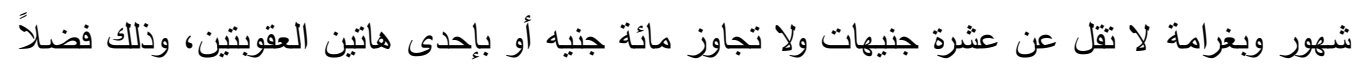

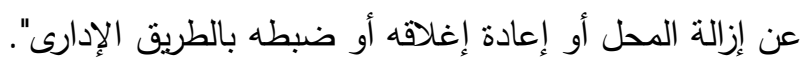


واحداً أو أكثر من العقوبات الآتية: المنع بصفة نهائية أو لمدة خمس سنوات أو أكثر من

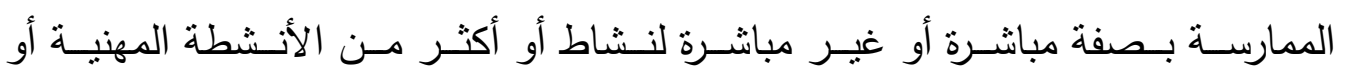
الاجتماعية(1) (1) ).

وحظر ممارسـة المهنة من الجزاءات التى يترتب على الحكم بها حرمان المحكوم

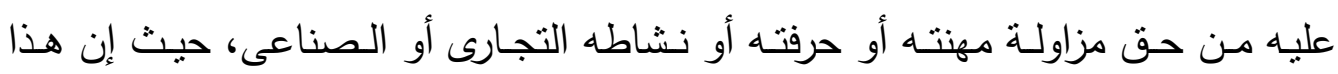
النشاط يشكل خطورة إجرامية تهدد الصحة العامة والسكينة وأمن وسلامة المجتمع. وتعد هذه العقوبـة مـن أكثر العقوبـات التى تطبق على الشخص المعنوى نظـراً

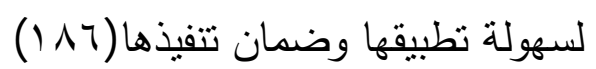

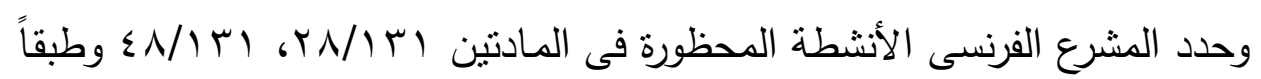
لهاتين المادنين يجب توافر شروط حتى يمكن الحكم بهذه العقوبة.

فيجب أولاً أن تكون هذه الأنشطة مهنية أو اجتماعية وعلى ذلك فقد يكون نشاط تجارى أو زراعى أو صناعى. ويجب ثانياً حتى يكون هناك مبرر للقضاء بهذه العقوبـة

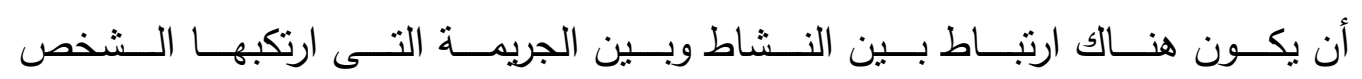

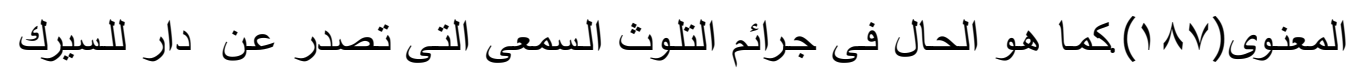
يدار طوال الليل.

(185) Art. 131-39 Lorsque la loi le prévoit à l'encontre d'une personne morale, un crime ou un délit peut être sanctionné d'une ou de plusieurs des peines suivants:

L'interdiction, a titre définitif ou pour une durée de cinq ans au plus, d'exercer directement ou indirectement une ou plusieurs activités professionnelles ou socialles.

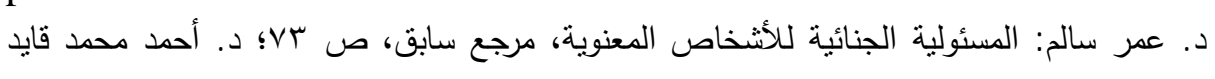

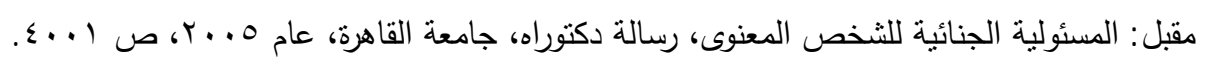

Larguier (J.) ; Droit penal des affaires 3 éme ed 1990, P. 38.

وراجع:

(187) Merle (R.) et Vitu (A.) Traité de droit criminél 6 ème éd 1988, No 749. P. 909. 
وقد أوضح المشرع مضمون العلاقة بين النشاط والجريمة المرتكبة فى نص المادة

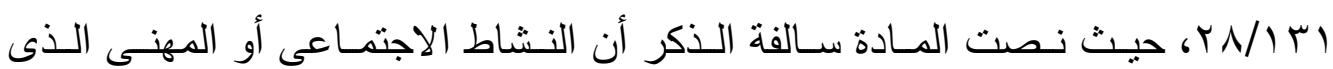
بموجبه أو بمناسبته ارتكبت الجريمة أو أى نشاط مهنى أو اجتماعى آخر يعرفه القانون

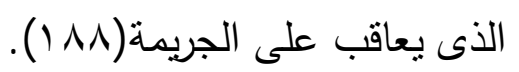

ومصطلح المهنى أكثر تحديداً وأدق من مصطلح الاجتماعى(19 (1) لأن النشاط المهنى بتضمن الأنشطة التجارية والصناعية والحرفية والزراعية والحرة أما مصطلح النشاط الناطي

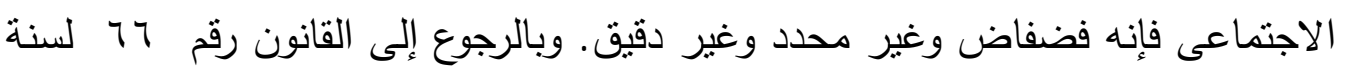

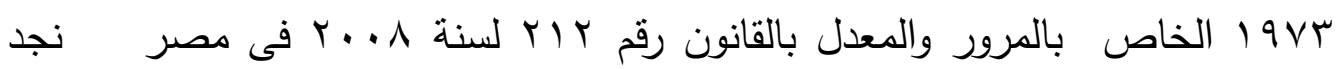

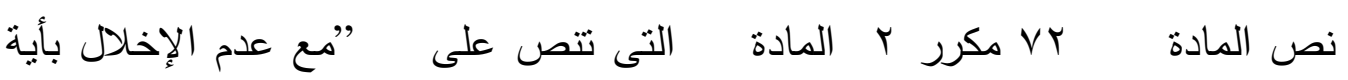

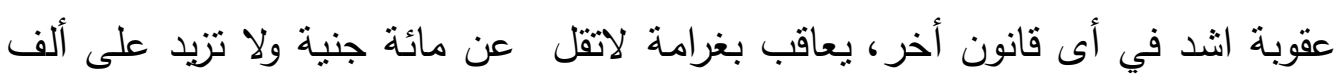
وخمسمائة جنيه، كل قائد مركبه تسبب في تلويث الطربق بإلقاء فضلات أو مخلفات بناء، أو إيه أثنياء أخرى، وكذلك كل من قاد مركبة في الطريق تصدر أصواتا مزعجة

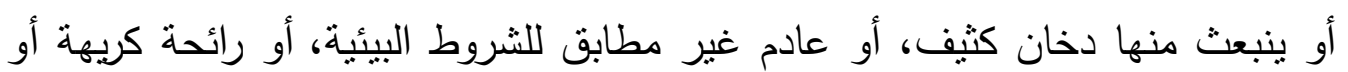

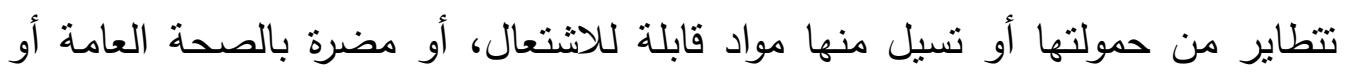
مؤئزة على صلاحية الطريق للمرور أو يتساقط أو إيذاء لمستعمليه. فإذا ارتكب قائد المركبة الفعل ذاته مرة ثانيه خلال ثناثثة أشنهر من تاريخ ارتكابه الفعل

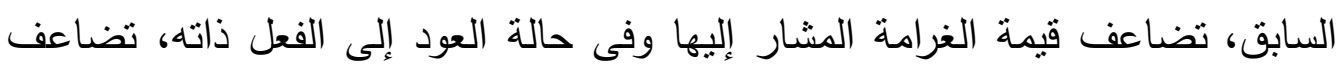

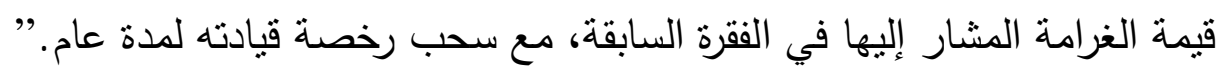

(188) Art. 131-28 L'interdiction d'exercer une activité professionnelle ou sociale peut porter soit sur l'activité professionnelle ou sociale dans l'exercice de laquelle ou à l'occasion de laquelle l'infraction a été commise, sur toute toute autre activité professsionnelle ou sociale définie par la loi qui réprime l'infraction.

(189) Le cannu; (P.) ; Dissolution; Fermeture d,etablissement. Op. Cit., P. 346. 


\section{المطلب الثالث}

\section{الجزاءات غير الجنائية}

لما كانت أغلب جرائم التلوث السمعى نرتكب من الأشخاص المعنويـة وفى ذات الوقت

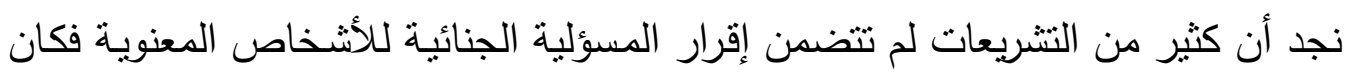
لابد مـن البحث عن جزاءات بديلـة للجزاءات الجنائيـة تتتاسب و طبيعـة الأشـخاص المعنوية ومع الأنظمة القانونية التى لاتأخذ بمسؤليتها الجنائية ومن أهم هذه الجزاءات الجزاء الإدارى ( الفرع الأول) والجزاء المدنى (ا الفرع الثانى):

\section{الفرع الأول}

\section{الجزاء الإدارى}

الجزاءات الإدارية هى مجموعة من الإجراءات التى تتخذها الإدارة لمنع وقوع الجريمة أو

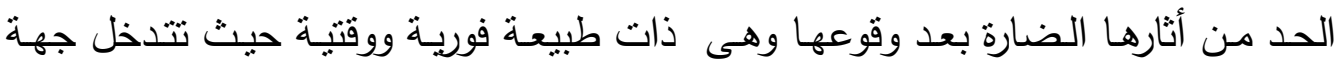
الإدارة قبل تفاقم الأضرار الناجمة عن السلوك الإجرامى لاتخاذ إجراءات على نحو سريع

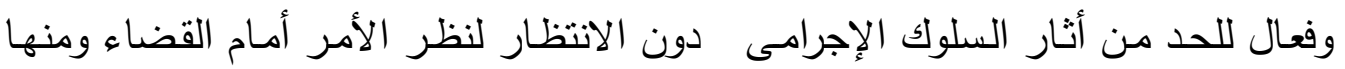
غلق المنشأة ( الغصن الأول) ووقف أو إلغاء التزخيص (الغصن الثانى):

\section{الغصن الأول}

\section{غلق المنشأة أو وقف العمل بها}

وقف العمل بالمنشأة هو جزاء مؤقت تلجأ إليه الإدارة فى مواجهة الأشخاص المعنوية فى مخالفتها للقوانين المتعلقة بالبيئة والصحة العامة و في إطار الغلق هواه الإدارى، فإن المشرع المصرى أعطى للسلطات الإدارية المختصة مكنة إغلاق

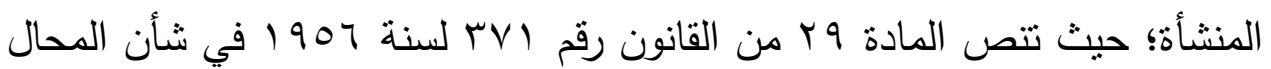
العامة على أنه " يغلق المحل إدارياً أو يُضبط إذا تعذّر إغلاقه في الأحوال

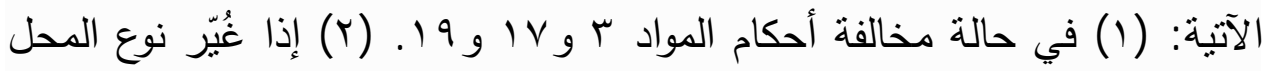

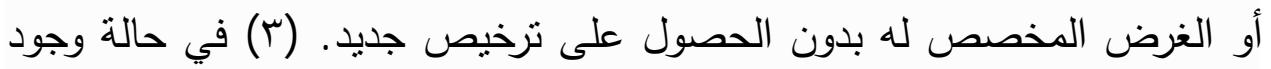


خطر داهم على الصحة العامة أو على الأمن العام نتيجة لإدارة المحل. (ع) في حالة بيع المخدرات أو السماح بتداولها أو تعاطيها في المحل. ويجوز غلق المحل إدارياً أو ضبطه إذا تعذّر إغلاقه في الأحوال الآتية: (1) في حالة مخالفة أحكام

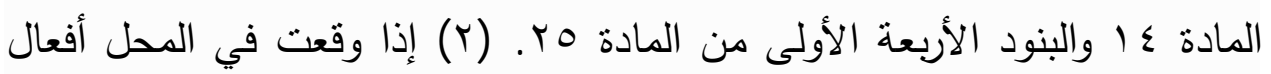

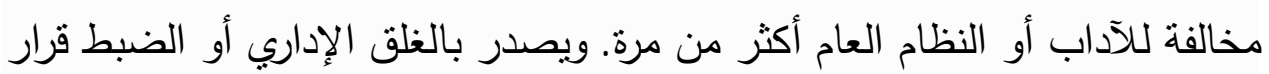
مسبب من الإدارة العامة للوائح والرخص أو فروعها فيما عدا حالة بيع المخدرات أو الو السماح بتداولها أو تعاطيها في المحل وحالة وقوع أفعال مخالفة للآداب أو النظام العام أكثر من مرة وحالة وجود خطر داهم على الأمن العام فيصدر فيها القرار من

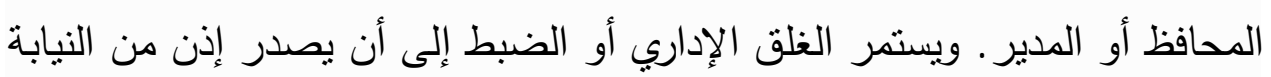

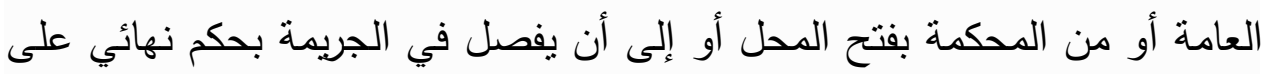
أنه إذا كان الغلق الإداري أو الضبط لوقوع أفعال مخالفة للآداب أو للنظام العام

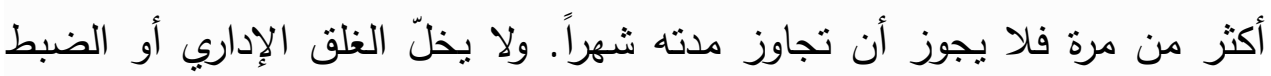
بتوقيع العقوبات المنصوص عليها في هذا القانون. فيجب غلق المحل إدارياً في حالة وجود خطر داهم على الصحة العامة أو على الأمن العام نتيجة لإدارة

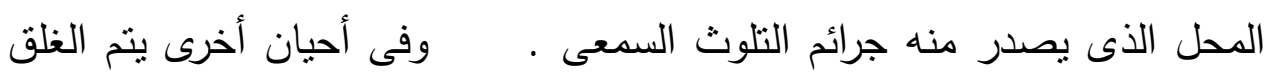
الإدارى تحت مسمى التحفظ على المنشأة كما هوالحال فى الفقرة الثانية من المادة

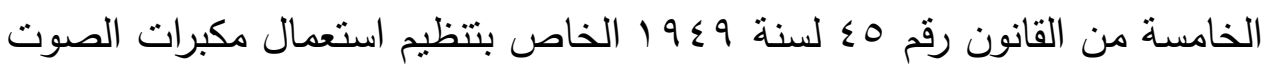
والذى أعطى للسلطة الإدارية التحفظ على المنشأة فى حالة الخطر على الصحة العامة بقولها ( يجوز للسلطة المختصة فى الحالات التى ترى فيها خطرا واضحا

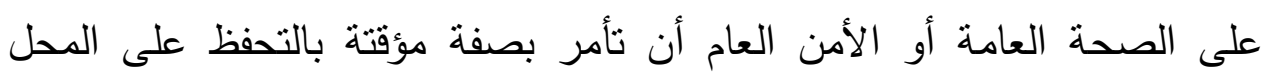

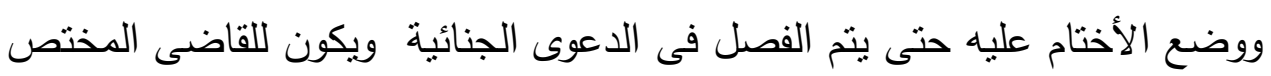

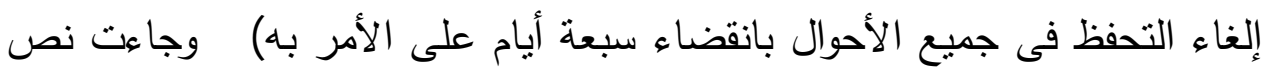

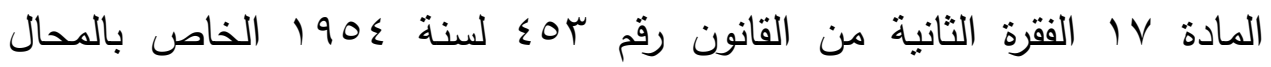

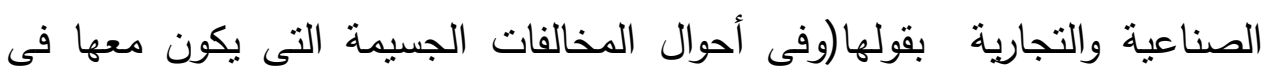
استمرار فتح المحل خطر واضح على الصحة العامة أو الأمن العام يتم التحفظ 
على المحل ووضع الأختام عليه وبعرض محضر الضبط على القاضى الجزئى لتأييد أمر الضبط خلال عا ساعة.

وفى التشريع الليبيى نجد الغلق الإدارى تم النص عليه فى المادة با من

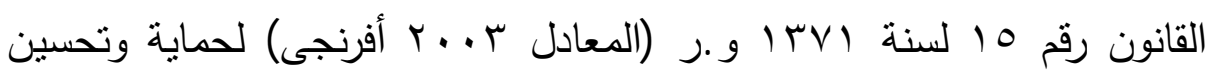

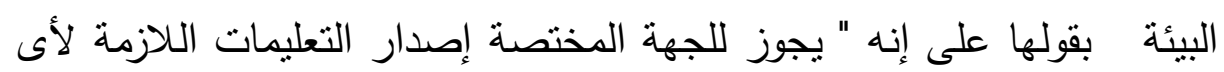
مصنع أو منشأة أو معمل بإدخال تغييرات على المبنى الخاص بها أو طريقة

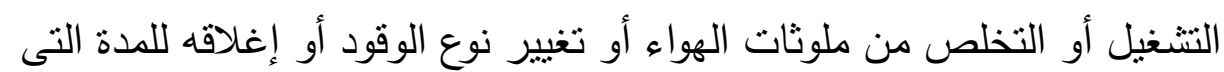

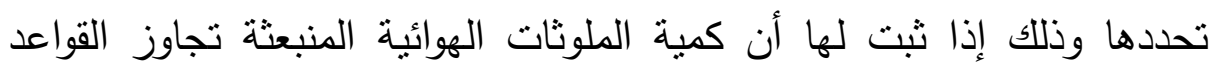
والمعايير الصادرة في الخصوص وأن في استمرار ذلك تعريضاً للصحة العامة للخطر أو تلويثاً للبيئة". ويلاحظ أن المشرع الليبي لم يضع حد أقصى لمدة الإغلاق، يجب على الجهة الإدارية أن تطبقه وهذا يعطى جهة الإدارة

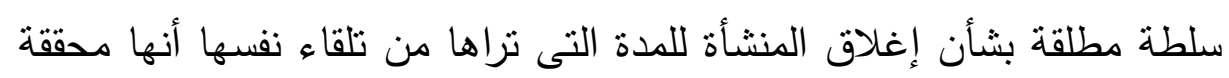
للغرض الذى من أجله منحت سلطة الغلق. . وفى قانون حماية وتحسين البيئة

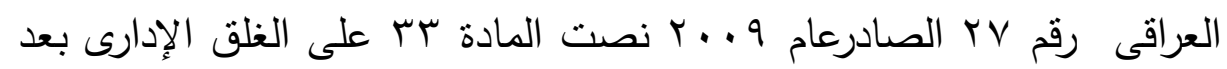

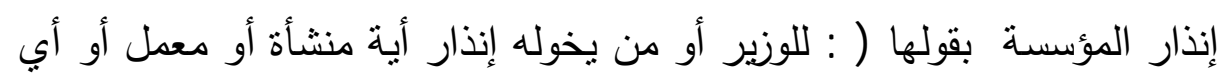

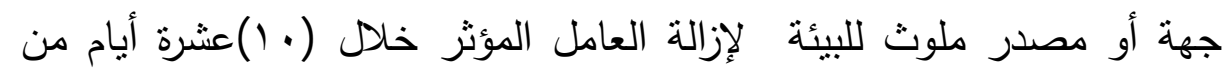

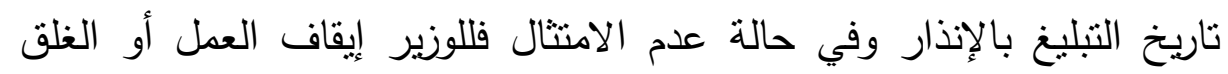

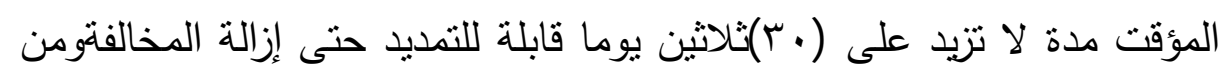

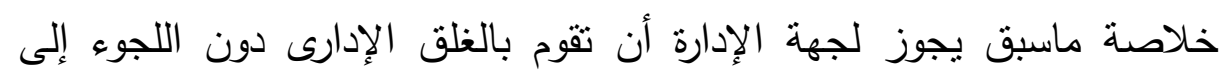
القضاء فى جرائم التلوث السمعى التى ينزتب عليها ضرر بالصحة العامة .

\section{الفصن الثانى}

\section{إلغاء أووقف التزخيص}

من أثند الجزاءات الإدارية إلغاء الترخيص أو وقفه لمدة معينة فى حالة مخالفة

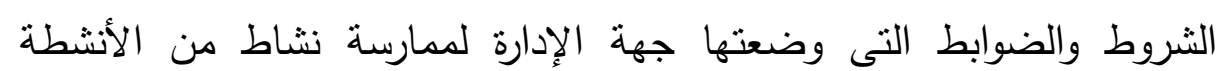


المسبية للتلوث السمعى. من ذللك مانص عليه المشرع المصرى فى المادة

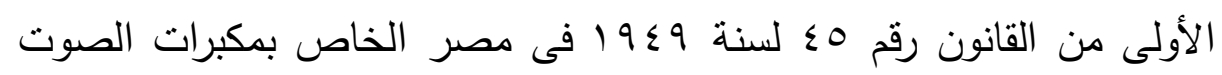
التى تتص على أنه ( لا يجوز تركيب أو استعمال مكبرات الصوت في المحال العامة أو الخاصة أو في المنازل أو في الحفلات بحالة مؤقتة أو مستديمة إلا لأل الهال بناء على ترخيص سابق من المحافظة أو المديرية، ولا يجوز استعمال هذه المكبرات إلا للأغراض التي صدر الترخيص من أجلها، ولا يجوز بأية حال منح

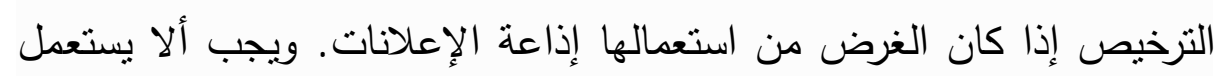
مكبر الصوت إلا في داخل مكان معد لذلك لا يقل مسطحه عن مائتي منر وألا يتجاوز صوته الحاضرين . ويجوز للمحافظة أو المديرية إلغاء الترخيص في أي وقت إذا وقعت مخالفة لشروط الترخيص.) ومن استقراء هذا النص نجد أنه أنه وضع ضوابط وشروط معينة لاستعمال مكبرات الصوت وفى حالة المخالفة

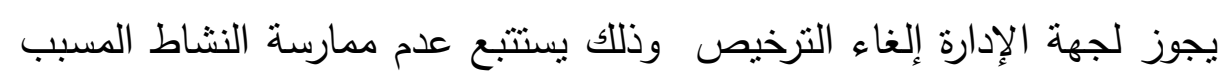

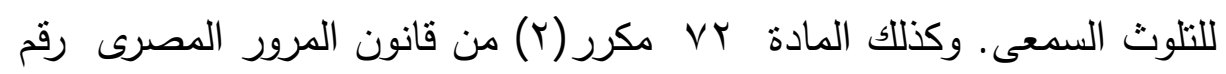

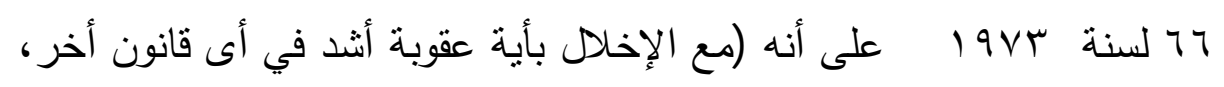

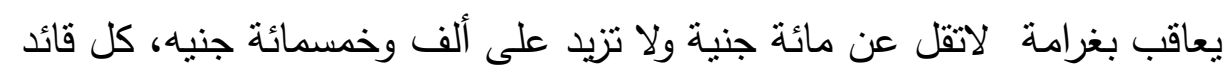
مركبه تنبب في تلويث الطريق بإلقاء فضلات أو مخلفات بناء، أو أية أشياء أخرى، وكذلك كل من قاد مركبة في الطريق تصدر أصواتا مزعجة أو ينبعث منها دخان كثيف، أو عادم غير مطابق للشروط البيئية، أو رائحة كريهة أو هركيه فئه

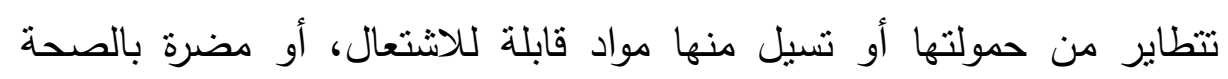
العامة أو مؤئرة على صلاحية الطريق للمرور أو يتساقط أو إيذاء لمستعمليه

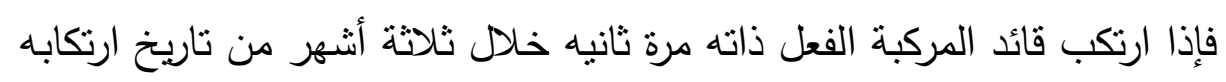

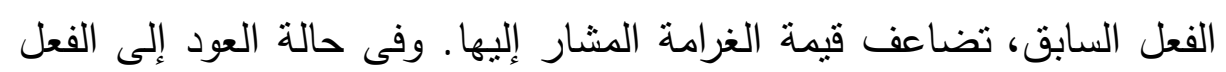

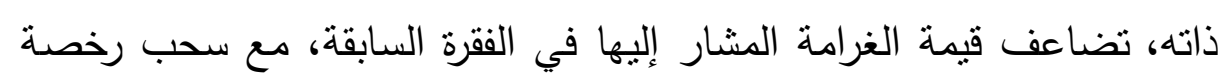

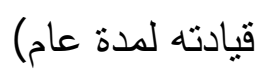




\section{الفرعالثانى}

\section{الجزاءات الملدنية}

الجزاء المدنى هو الأثر الذى يرتبه القانون المدنى على مخالفة قواعده

ويأخذ صـوراً متعددة فقد يكـون عينيـاً أو تعويضياً أو يتضمن محـو كل أثر

للمخالفة القانونية. ( 9 ( )

والجزاء العينى يكون إجبار الثخص على إزالة المخالفة وإعادة الحال إلى ماكان

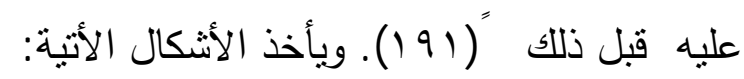

\section{الفصن الأول}

\section{التعويض التصان}

يتخذ الجزاء المدنى صورة التعويض المالى dommages intérets إذا استحال إعادة الحال إلى مـا كانت عليـه قبل وقوع المخالفـة من جانب الشخص المتسبب فيها كالثخص الذى يتسبب فى إزعاج وتوتر وقلق الأخرين بسبب الحفلات الصاخبة ليلا أو

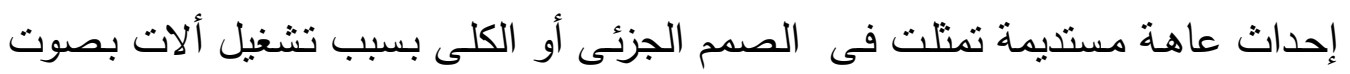

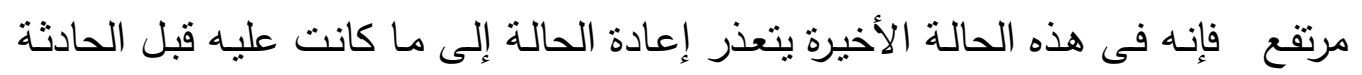

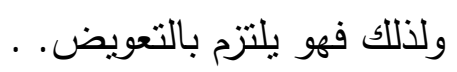

ويلاحظ أن الفعل الواحد للمخالفة قد يشكل مخالفة للقانون الجنائى والمدنى فى لقى ذات الوقت كالثخص الذى يقوم باستخدام ألعاب نارية ومفرقات ليلا يترتب عليها

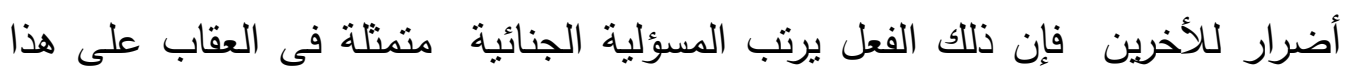
الفعل بالحبس أو الغرامة وجزاء مدنيا منتثل فى التعويض الذى يطالب به كل من لحقه ضرر من فحل هذا الثخص. ففي جميع الأحوال التى يتعذر إعادة الحال إلى كان

r CARBONNIER (J ), : droit civil introduction puf 1969 p 18

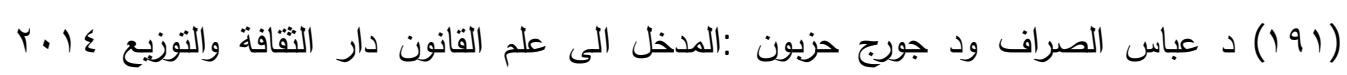
ص 


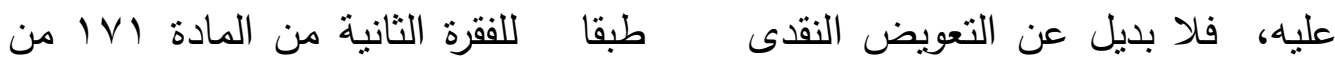
القانون المدني المصرى على إنه " يقدر التعويض بالنقد".وللثخص المتضرر والمجنى عليه له الخيار أن يطلب التعويض عن طريق رفع دعوى أصلية أمام المحكمة المدنية أو الأدعاء المدنى أمام المحكمة الجنائية. وتطبيقا لذلك قضت فيت محكمة استئناف الجيزة بإزالة أجهزة التكييف والمداخن الخاصة بأحد الفنادق بالمهندسين استتاداً إلى إضرارها بالصحة العامة وإزعاج السكان. وذكرت تفصيلاً لذلك أن موظفاً يقيم في شقة بالدور بالدة الثامن بعمارة في المهندسين أقام دعوى ضد صاحبه تضمنت تضرره من قيام صاحب واحب الفندق بتركيب ثلاثة مواتير للمياه على سطح الفندق وبناء برجين من المعدن خاصين بأجهزة التكييف فضلاً عن المدخنة الخاصة التى يشمل طولها ارتفاع شقة الموظف لئل وجاء في حيثيات الحكم أن المحكمة اطمأنت لتقرير الخبير الذى أكد أن الحواجز

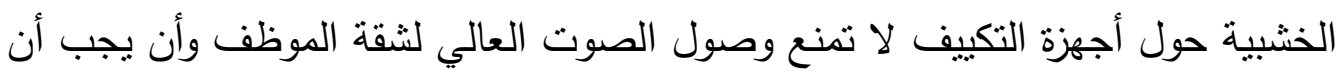

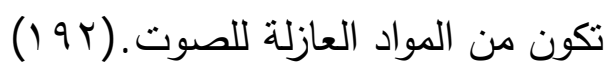

\section{الفصن الثانى}

\section{إعادة الحال إلى ماكان عليه}

المقصود هو إزالة المصدر الذى تصدر عنه الضوضاء أو مصدر الإزعاج. ولقد نصت

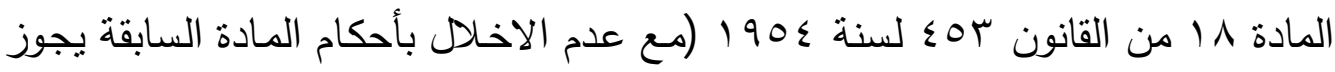
للقاضى أن يحكم بإغلاق المحل المدة التى يحددها فى الحكم أو إغلاقه أو إزالته نهائيا.

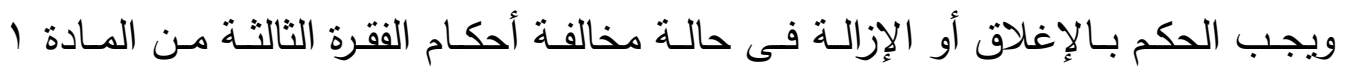
والمادنين r، 11 ـ وفى حالة الحكم بالإغلاق أو الإزالة تكون مصاريف الضبط والإغلاق والإزالة على عاتق المخـالف.) ولخطورة استمرار ممارسـة النشاط المهنى الذى يصدر عنه الإزعاج والتلوث السمعى فقد نصت المادة 9 الإدن ذات القانون على تتفيذ حكم أول

(192) جريدة الأخبار (بمصر ) ، الصادرة بتاريخ 17 أبريل ع99 19، ص 11. 
درجة رغم الطعن بالاستئناف (r9 (1) كذللك نص المشرع الجزائرى فى المادة r • ( من القانون رقم • ب/ • (يعاقب بالحبس لمدة سنة واحدة وبغرامة قدرها خمسمائة ألف دينار كل من استغل المنشأة دون الحصول على الترخيص المنصوص عليه في المـادة 19

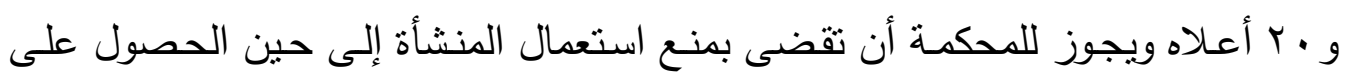

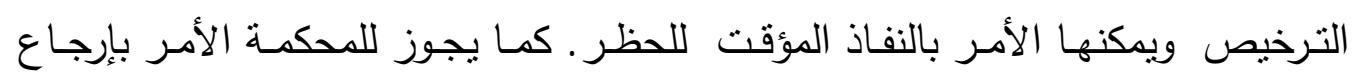

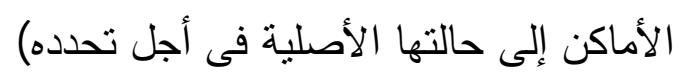

(ب9 1) =) المادة 9 (1 فى أحوال الحكم باغلاق المحل أو ازالته يجوز للمحكمة أن ثأمر بالنفاذ رغم

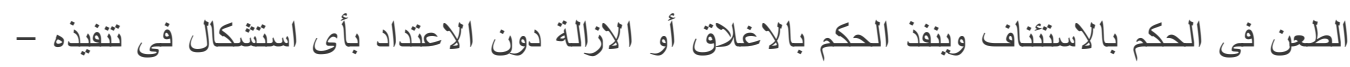

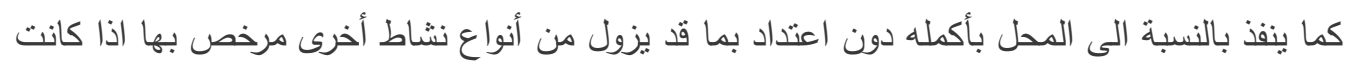

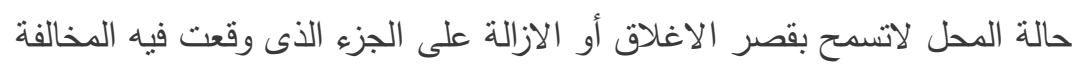




\section{النتائج}

1 - التلوث السمعى يشكل خطر كبير على الصحة العامـة حيث يسبب كثير من

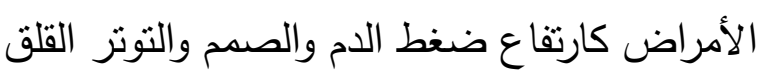
r- لـم يحظى التلوث السمعى بـالتظظيم القانونى الذى يكفل حمايـة فعالـة للصحة

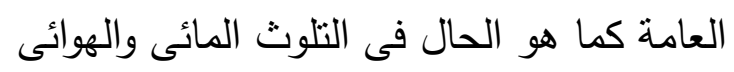
r- التشريعات الأوربية تضمنت عقوبات رادعة لمواجهة جرائم التلوث السمعى ع - تقاهـة العقوبـات فى غالبيـة التشريعات العربيـة مـع غيـاب كثير مـن النصوص العقابية التى تواجهة كافة مصادر التلوث السمعى ○ـ عدم تعديل النصوص الموجودة فى بعض القوانين لمسايرة التطور السريع الهائل

$$
\text { فى مصادر التلوث السمعى }
$$

7- عدم وجود تعريفات وضوابط محددة لما يعتبر تلوث سمعى محظور ومالايعتبر غير ذلك V- أن التلوث السمعى أشد خطورة من التلوث المائى والهوائى على الصحة العامة

$$
\text { رغم ضعف وقلة التتظيم القانونى له }
$$

ᄉ- ، توجد مشاكل عملية تجعل من الصعب جدًا على المواطن معرفة السلطة العامة المختصة التي يمكن اللجوء إليها عند حدوث تلوث ضوضيائى . علاوة على ذلك، لا تمنلك أقسام الشرطة المعدات الفنية الضرورية لتحديد مستوى الصوت أو التحكم في مصادر التلوث الضوضائي في فترة زمنية قصيرة. وبالمتل، في معظم الحالات، لا تكون السلطات المحلية في وضع مالي يسمح

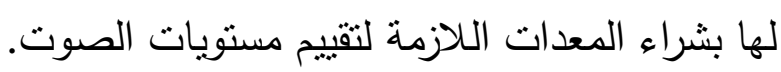




\section{التوصيات:}

1 - ـ وضع تعريف محدد للتلوث من جانب المشرع

r- ضرورة إعادة النظر فى النشريعات المتعلقة بالتلوث السمعى ووضعها فى قانون واحد بدلا تتاثرهـا بين عدة قوانين منها قانون العقوبات وقانون المرور وقانون البيئة وقـانون الطيـران والمحال التجاريـة والصناعية وقـانون استعمال مكبرات الصوت وقانون العمـل وقانون الباعـة الجـائلين وقانون الصحة وقانون تتظيم الملاهى وغيرها

r- تشديد العقوبـات على ارتكاب جرائم التلوث السمعى مـع جعل كل من ظرف

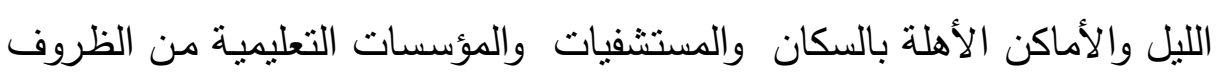
المشددة لارتكاب هذه الجريمة. ع - إخراج كل الأنشطة المهنية والتجارية المقلقة والمنشأت الصناعية والأسواق خارج

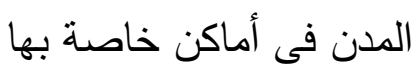
هـ تـضمين التشريعات المتعلقـة بـالتلوث الـسمعى عقوبـات تبعيـة رادعـة كغلـق المؤسسة وحلها وحظر النشاط وإلغاء الترخيص

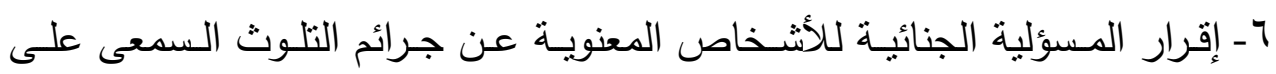
نطاق واسـع بحيث تطبق عليها جميع العقوبات التى يتضمنها القانون الجنائى باعتبارها من المصار الرئيسية للتلوث السمعى. 


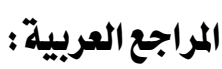

أحمد فتحى سرور : الوسيط فى قانون العقوبات، القسم العام، دار النهضة العربية، الطبعة الخامسة، طبعة 9 19 19 د. أحمد عبدالكريم سلامة ، مبادئ قانون حماية البيئة دراسة تأصيلية في الأنظمة الوطنية والدولية الطبعة الأولى بون ناشر القاهرة 1997

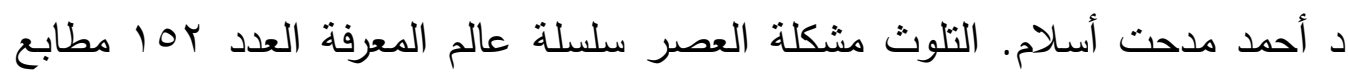

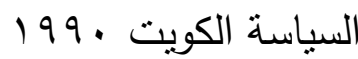
د. أحمد عوض بلال مبادىء قانون العقوبات المصرى القسم العام دار النهضة

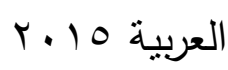
د. أشرف هلا. جرائم البيئة بين النظرية والتطبيق دار الفكر العربى بالقاهرة الطبعة

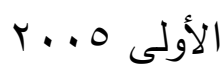
د. . أمين عبده محمد دهمش: تعدد الجرائم فى التشريع الوضعى المقارن بالققه

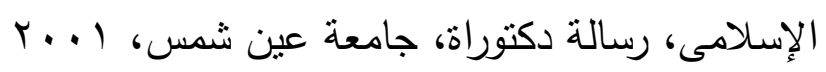
د إبراهيم عطا شعبان: النظرية العامة للامتناع فى الثريعة والقانون الجنائى، جامعة القاهرة، عام إبرام 191

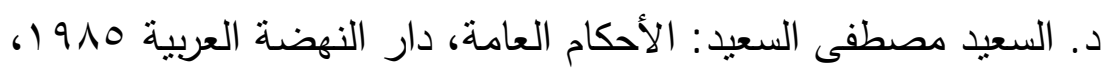

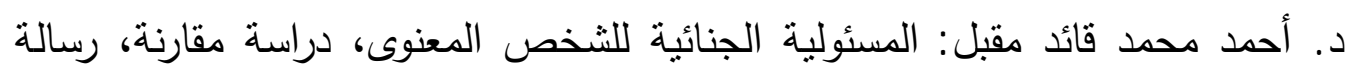

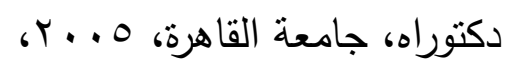
أحمد عوض بلال : مبادئ قانون العقوبات المصرى، القسم العام، دار النهضة العربية، 6r...T/T... b د. أحمد حامد البدرى الحماية القانونية للبيئة فى المملكة العربية السعودية معهد الأدارة

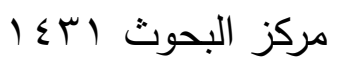

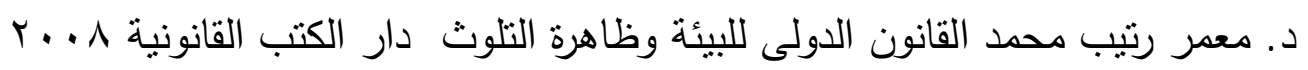

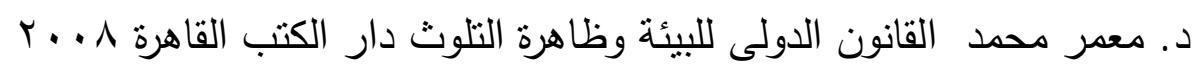


د. محمد سعيد ود ـ رشيد الحمد البيئة ومشكلاتها سلسلة عالم المعرفة العدد بr مطابع

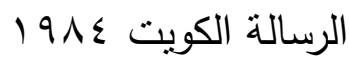
د خالد خليل الطاهر قانون حماية البيئة في الأردن دراسة مقارنة الطبعة الأولى بدون ناشر 1999 د. عصام الحناوي، "قضايا البيئة في مئة سؤال وجواب"، مجلة البيئة والتنمية، بيروت، r...

-د. نظيمة أحمد محمود سرحان،منهاج الخدمة الاجتماعية لحماية البيئة من

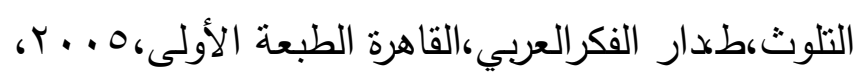
-د برفعت رشوان: الأرهاب البيئي في قانون العقوبات دار النهضة العربية الطبعة الأولى النى r... T

دراتب السعود، الإنسان والبيئة، دراسة في التربية البيئة،دار الحامد للنشر

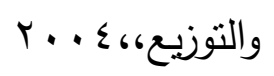

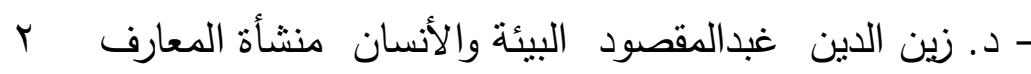

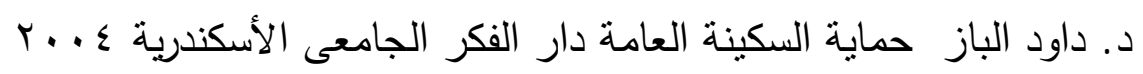
د، محمود نجيب حسنى شرح قانون العقوبات القسم العام الطبعة السادسة دار النهضة

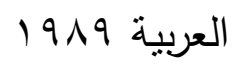

-د. محمد عبد البديع أقتصاد حماية البيئة نشأته ومبرراته مجلة مصر المعاصرة العدد 199. عام $19 .-\leqslant 19$ د. محمد أحمد مصطفى أيوب: النظرية العامة للامنتاع فى القانون الجنائى، رسالة

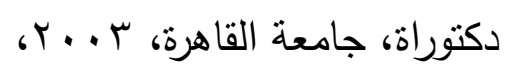
راجع فى ذلك: روبيرت أراكب ورونالد ستيد هام: الإجراءات القضائية فى أمريكا، ترجمة

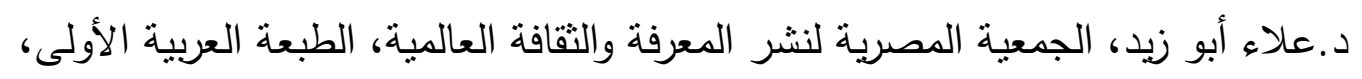
$6199 \mathrm{~V}$

د. عبد الفتاح مصطفى الصيفى: الاشتراك بالتحريض ووضعه من النظرية العامة

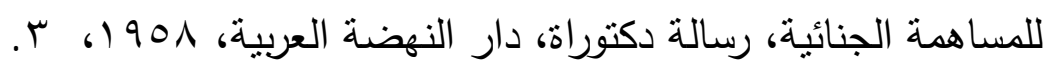


ولنفس المؤلف القاعدة الجنائية، دراسة تحليلية لها على ضوء الفقه الجنائش المعاصر ،

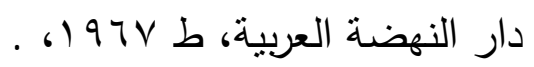

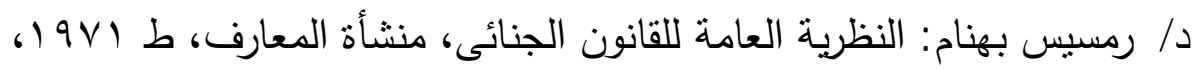
-د. محمد محيى الدين عوض: المبادئ الأساسية التى يقوم عليها القانون الجنائى

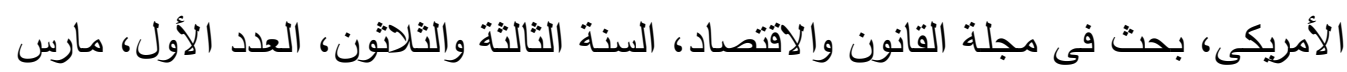

. يسر أنور على: شرح النظريات، شرح النظريات العامة فى قانون العقبات، دار

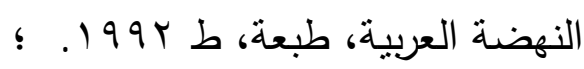
-د. محمد زكى أبو عامر : قانون العقوبات القمم العام، دار الجامعة الجديدة للنشر

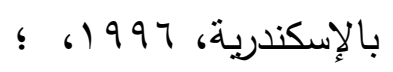
د. محمد عيد الغريب: شرح قانون العقوبات، القسم العام، الجزء الأول، النظرية العامة

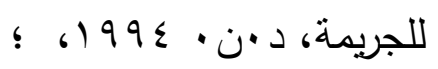
د. عبد الفتاح الصيفى: الأحكام العامة للنظام الجنائى فى الثريعة الإسلامية والقانون،

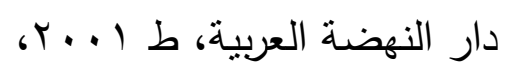
د. عبد الفتاح الصيفى المطابقة فى مجال التجريم، دار النهضة العربية، الطبعة الثالثة، ؛ 61991

محمد على على سويلم: تكييف الواقعة الإجرامية، رسالة دكتوراه، عين شمس، 999 (1)

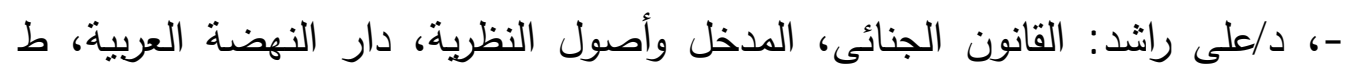
$19 V \varepsilon$ د. أحمد حامد البدرى الحماية القانونية للبيئة فى المملكة العربية السعودية معهد الأدارة

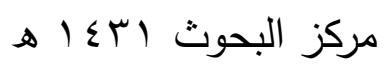
د/ محمد زكى عامر : القسم العام، دار الجامعة الجديدة للنشر ، الإسكندرية،

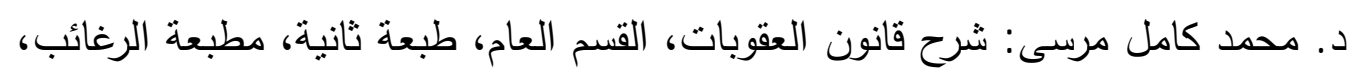

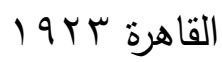

؛ ود ـ محمود نجيب حسنى: القسم العام، طبعة، دار النهضة العربية، 919 19 1) 
د. عبد الفتاح الصيفى: الأحكام العامة فى النظام الجنائى فى الثريعة الإسلامية والقانون الوضعى، طبعة | . . r، دار النهضة العربية

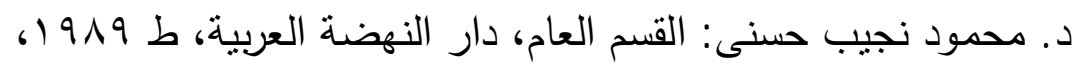

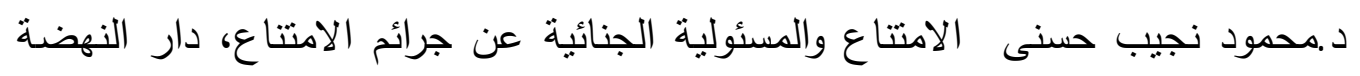

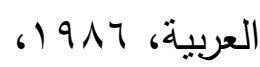
-د. محمود نجيب حسنى: الفقه الجنائى الإسلامى، ، دار النهضة العربية، الطبعة

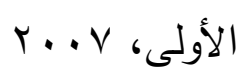
د. محمود مصطفى: شرح قانون العقوبات، القسم العام، دار مطابع الثعب، ط 7 ج، عام $6197 \varepsilon$ د. حسن أحمد شحاتة، التلوث الضوضائى وإعاقة التتمية، مكتبة الدار العربية للكتاب

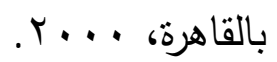
عادل عازر : النظرية العامة فى ظروف الجريمة، القاهرة، المطبعة العالمية، طبعة 6) $97 \mathrm{~V}$

عبد الأحد جمال الدين ود. جميل عبد الباقى الصغير : المبادئ الرئيسية فى القانون الجنائى الجريمة والمسئولية الجنائية، الطبعة الثالثة، دار الثقافة الجامعية، ـو 99 د. نور الدين هنداوى، الاعتداء على البيئة جريمة مجهولة، المؤتمر العلمى التطبيقى

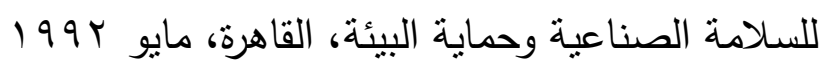
سمير الثناوى: النظربة العامة، ، قانون الجزاء، الكويت، الكتاب الأول، الجريمة، مائ، البهاء

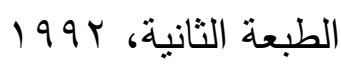

رعوف عبيد : مبادئ القسم العام من التشريع العقابى، دار الفكر العربى، 9 و 1، ؛ ؛

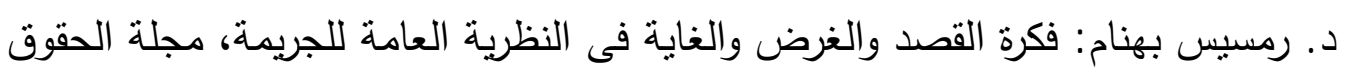
تصدرها كلية الحقوق بالإسكندرية، السنة السادسة، بهو 19 د. رؤوف عبيد: السببية الجنائية بين الفقه والقضاء دراسة تحليلية مقارنة، الطبعة

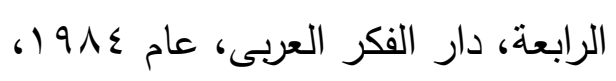


على راثد : بحث بعنوان الإرادة والعدد والخطأ والسبيية فى نطاق المسئولية الجنائية،

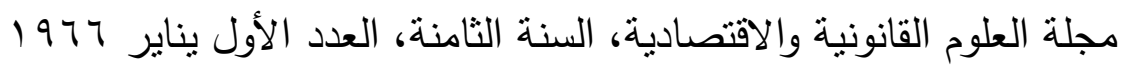
د. محمد محيى الدين عوض . (بحث منشور فى مجلة القانون والاقتصاد، جامعة

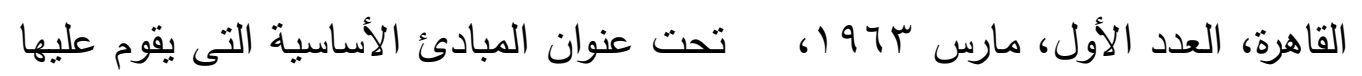

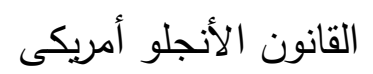
راجع: د. محمد مصطفى القللى فى المسئولية الجنائية، القاهرة، مطبعة جامعة فؤاد

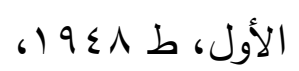
د. محمد عمر مصطفى: الجريمة وعدد أركانها، بحث فى مجلة القانون والاقتصاد،

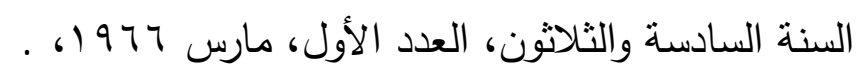
د. محمود نجيب حسنى: النظرية العامة للقصد الجنائى، دراسة تأصيلية مقارنة للركن المعنوى فى الجرائم العمدية، دار النهضة العربية، الطبعة الثالثة، د9 199 ود . محمد زكى محمود : آثار الجهل والغلط فى المسئولية الجنائية، رسالة دكتوراة، دار

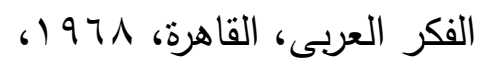

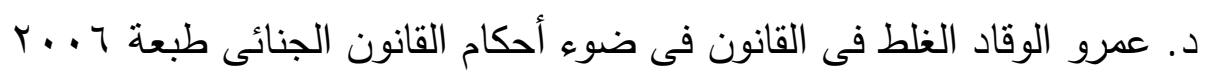
د. . على محمود حمودة: الغلط فى القانون ومدى اعتباره مانعا من المسئولية الجنائية،

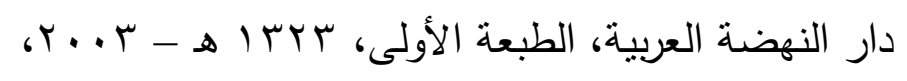
فى ذلك راجع د. مصطفى العوجى . القانون الجنائى الجزء الثانى المسؤلية الجنائية

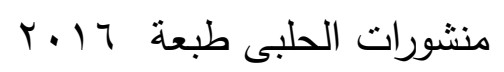
د رؤوف عبيد: مبادئ القسم العام من التشريع العقابى، الطبعة الرابعة، دار الفكر

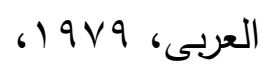
د. على راثد : القانون الجنائى، المدخل وأصول النظرية، الطبعة الثانية،، دار النهضة

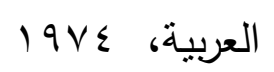
د. كامل السعيد : شرح قانون العقوبات الأردنى فى الجرائم الواقعة على الأشخاص، مكتبة

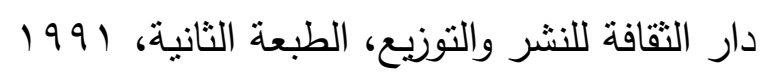


د. فوزية عبد الستار : النظرية العامة للخطأ غير العدى، دار النهضة العربية، ط I $9 V \mathrm{~V}$ الخطأ الغير العددى بحث فى مجلة المحاماة، العددان السادس والسابع، السنة الرابعة والأربعون، فبراير ومارس ع 97 د. مصطفى محمد عبد المحن: النظام الجنائى الإسلامى، القسم العام، العقوبة، الكتاب

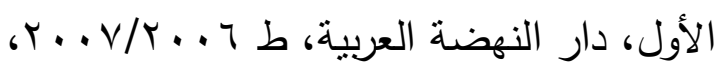
د. محمد مؤنس محب الدين، البيئة في القانون الجنائى، مكتبة الانجلو المصرية

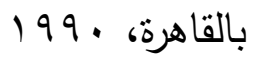
, . مصطفى منير، إساءة استعمال السلطة الاقتصادية، الهيئة المصرية العامة للكتاب

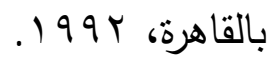
وراجع أيضاً: د. عمر السعيد رمضان: فكرة النتيجة مجلة القانون والاقتصاد، عام 6) 971

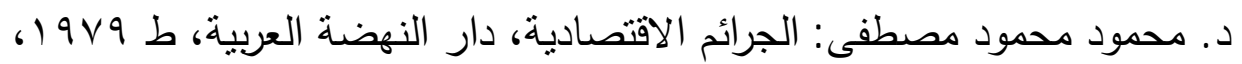

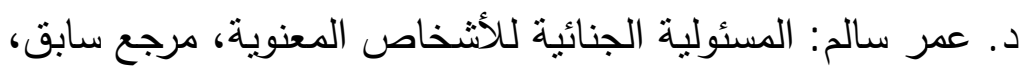

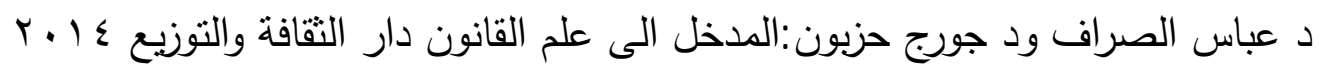
؛ والدكتور / محمود نجيب حسنى: علاقة السببية فى قانون العقوبات، دار النهضة، 6 191

؛ ود ـ مأمون سلامة: القسم العام، القسم العام، دار الفكر العربى، طبعة ـ99 199،

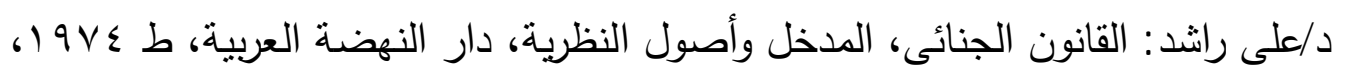




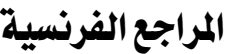

; Ancel (A.) et Srzentic (N.); les grands systémes de droit pénal contemporains; le droit pénal nouveau de la yougoslavie; les éditions de l`Epargne. 1962.

Ancel (M.) et Strahl (I.): le droit pénal des pays scandinaves les édition de l'epargne Paris, 1969

Ayache (A.B.), Dictionnaire de droit pénal général et procédure pénal ellipses édition 2001

Alice Elizabeth González. What Does "Noise Pollution" Mean? Journal of Environmental Protection, 2014

Boiazrd (M.) Amende, confiscation affichage ou communication de la decision Rev. Soc. 1993,

Bayer (V.), l'infractions non intentionnelles cours de doctaret le Caire, 1963

; Bouzat (P.) et pinatel (J.), Traite de Droit Pénal et de criminalogie, I. 1963

Bouzat (P.), Traité théorique Partique de droit Pénale 1951

Beatrice chapleau - Mussau, questions sur 1,erreur de droit en reflexions sur la nouveau code penal sous le direction de christine lazerges 1995

; Couvrat (P.), limprevoyance, dans le droit pénal des loisirs sous la présidence de a chavanne édition cujas 1990. .

- CARBONNIER (J),: droit civil introduction puf 1969

Domedieu de vabres (H.), Traité de droit criminal et de legislation Pénale comparee, 1947

Pradel (J.) et Varinare (A.), Les grands arrêts du droit pénal général, 3 éme éd Dalloz, 2001

Robret (J. H.), Droit pénal général P.U.F. éditions 1998,

$\_$Merle (R.) Vitu (A.) Traite de droit criminel t. I. Droit Pénal général 6 éme éd cujas (Paris) 1984 
Stefani (G.) levasseur (A.), Bouloc:. driot penal general 13 éme éd.

Garraud ( $\mathrm{R}$ traite théorique et partique du droit pénal Francais 3 éme éd Paris T. I. 1931; T. 2.

Vidal (G.) et Magnol (J.), Cours de Droit criminel et de science pénitentiaire Paris, 1928.

) Stefani, (G.), levasseur (G.) et Bouloc (B.), Droit Pénal géneral, 15 éme éd dalloz 1995..,

Levasseur (G,), chavanne (A.), montreuil (J.) et Bouloc (B.), Droit Pénal général et procédure Pénale, 13 éme éd Dalloz 1999.

) Veron (M.), Droit pénal spècial 7 éme éd Armand colin, 1999,

; Merle (R.) et Vitu (A.), Traité de droit criminal t.I. Droit penal général 6 éme éd Cujas (Paris) 1984,

Vitu (A.): Traite de Droit Criminel t. I droit Penal general Eion Cujas sixieme Paris éd, 1984

R Assat (M.L.): Droit Pénal P.U.F. 1987 No. 236

Vidal (G.) et Magnol (J.):Cours de droit criminel et de sience péntitentiare, Paris, 1928. G Arraud (R.): traite theorique et pratique du Droit Penal Francais t. I. 3 éme éd Surey 1913

Soyer (J.C.): Droit pénal et procedure pénale 19 edition L.G.D.J. 2006

Srzentic (N.); les grands systémes de droit pénal contemporains; le droit pénal nouveau de la yougoslavie; les éditions de l'Epargne. 1962

Levasseur (A.) chavanne (A.) Montreuil (B.) et Bouloc (B.) droit pénal général et procedure pénale 13 edition sirey 1999

-Stefani (G)Levasseur (G) bouloc(B) droit penal -general dalloz 2000

Stefani (G.), levasseur (G.) et Bouloc (B.), Droit pénal général, 16 éme éd dalloz 1997. 
Donnedieu De Vabres (H.), Traité élémentaire de droit criminel 3 éme éd Paris, 1953139.

Viridiana (F.) l'erreur sur le droit commentaire d'arrêt travaux dirigés de droit penal procedure penologie dirigé par Gabriel Roujou de Boubée ellipses éd 2001.

Merle (R.) et Vitu (A.), Traité de droit criminel 6 émé éd cujas 1984 ,

Pradel (J.), droit penal T. I. éd cujas Paris, 1994

Rassat (M.L.) droit pénal édition 1987, ;

levasseur (G.), Chavanne (A.), montreuil (J.), Bouloc: droit Pénal genéral et procédure Pénale 13 éme éd sirey 1999

Levasseur stefani (G.) Levasseur (G.) et Bouloc) B.), droit Pénal éd, 15 éme éd 1995 Dalloz

Pradel (J.), droit Pénal comparé éd Dalloz 1995

Larguier (J.), Droit Pénal général, 15 éme éd Dalloz 1995, 1995

Pradel (J.), Droit pénal générale T. I, introduction général droit pénal général éd, cujas, 1992,

levasseur (G.) et chavanne (A.) montreuil (J.) et Bouloc. (B.): Droit pénal général et procédure pénal 13 éme éd Dalloz 1999

Levasseur (G.), chavanne (A.) montreuil (J.) Bouloc (B.), Droit pénal général et procédure pènale éd Dalloz 1999 No. 190.

Vidal (G.) et Magnol (J.), Cours de droit criminel et de sciences pénitentiaire T. I

Merle (A.) et Vitu (A.), Traité de droit criminal, 5 eme ed Gujas 1984 T. I

Griffon.; De lintention en matiere pénal, thése Paris, 1991,

Roux (J.A.), Cours de droit criminel Français T. I. 1927.

Larguier (J.); Droit penal des affaires 3 éme ed 1990,

Merle (R.) et Vitu (A.) Traité de droit criminél 6 ème éd 1988 
; Alan Reed and Peter Seago: Criminal law sweet maxwell edition, 1999, Catherine elliott and Frances quinn; criminal law fifth edition, 2005

Andrew Ashwarth; Principles of criminal law Oxford University press 4 éd 2003

. Smith and Hogan. Criminal law eleventh edition 2005

William wilson, criminal law doctrine and the theory second edition 2003,

Nigel Foster and Satish sule, German legal system and laws, third edition, 2002

Alan Reed and Peter Seago, Criminal Law London Sweet Maxwell, 1999,

; Marianne Giles, Criminal law, Fourth edition 1996,

Raymond Youngs: English, French \& German comparative law Youngs edition 1998,

Janet Dine and James Gabert: Cases and materials on criminal law, 4 th edition, 2003,

; William Wilson: Criminal law Doctrine and theory second edition 2003,

; Robert (B.) Seidman; A sourcebook of the criminal law of Africa London 1966.

L.B. Curzan: criminal law seventh edition longman 1994. .

Smith and Hogan on criminal law Fifth Edition Butterworth, 1983, -

Michael. tmolan and Graeme Broadbent: Criminal law pitman publishing london 1994 
داعبد القادر الحيني إبرايير

Janet Dine and James Gobert; Criminal law cases and mterials on criminal law Oxford University press 4 éd 2003 ;

William Wilson; Criminal law Doctrine and theory 2 éd 2003.

. W. Cecil turner: Kenny,s outlines of criminal law Sixteenth Edition 1952, Cambridge university Press.

Michael J. Allen: Cases and materials on criminal law seventh editions London 1997.

Jonathan herring criminal law. criminal law palgrave Macmillan fourth edition 2005.

Smith and Hogan on criminal law Fifth edition Butterworth 1983 ; and Eleventh edition 2005

Michael Jefferson: Criminal Law longman group 1992

Micheal J. Allen: Cases and materials on criminal law fourth edition London 1997 ; Micheal t molan: Graeme Broadbent: Cases. Materials on criminal law, pitman publishend London Malon

Janet Dine and James Gobert, Cases and Materials on cirminal law Oxford University Press, 4 edtion 2003, .

criminal law Doctrine and theory second edition 2003 William Wilson

Smith and Hogan eleventh edition 2005

Nigel G. Foster - Satish sule. Assessoir: German legal system Laws, German legal system and laws Oxford university press third edition 2002.

L. B. Gurzon, Criminal Law, seventh Edition, 1994

Michael T Malon and Graeme Broad bent, criminal Law, Cases and Materials on criminal Law, 1994

Michael Jefferson, Criminal Law, longman group, 1992

William Wilson; Criminal law Doctrine and theory second edition 2003. 
Raymond youngs; English, French. German; comparative law edition 1998

Janet Dine and James Gobert; Cases and materials on criminal law 4 th edition 2003. ;

; Russell Heaton; Criminal law oxford university press second edition 2006 